\title{
ANÁLISE DO DISCURSO MUSICAL:
}

\section{UMA ABORDAGEM SEMIÓTICA}

Dissertação apresentada à Área de Semiótica e Lingüística Geral do Departamento de Lingüística da Faculdade de Filosofia, Letras e Ciências Humanas da Universidade de São Paulo, para obtenção do Título de Mestre.

Orientador:

PROF. DR. LUIZ AUGUSTO DE MORAES TATIT

São Paulo 
A dissertação Análise do discurso musical: uma abordagem semiótica discute e propõe soluções para a questão da aplicação do modelo de percurso gerativo de sentido à análise do discurso musical. A partir de uma exposição inicial onde se procura situar essa proposta analítica dentro da evolução da musicologia e da semiótica francesa, passa-se a uma discussão em profundidade da aplicação do modelo semiótico no que diz respeito à estrutura dos níveis fundamental e narrativo, tanto no que tange à organização sintática quanto semântica de cada patamar da significação. As explanações teóricas são fundamentadas diretamente a partir da análise de textos significativos do repertório ocidental, como a 5.a Sinfonia de Beethoven, a 4.a Sinfonia de Tchaikovski e a Fuga I do Cravo bem temperado de Bach. Em linhas gerais, o trabalho conclui por defender uma abordagem analítica que parte das aspectualizações presentes no nível de superfície para determinar a organização semântica do nível profundo no que diz respeito às modulações tensivofóricas e à ordenação de seu campo valencial. Postulada e justificada a presença de uma instância discretizadora responsável pela conversão das modulações em modalidades e das valências em valores, passa-se ao estudo do nível narrativo, que culmina com; a) a importante descoberta em nível musicológico do papel da dimensão semântica no processo de variação motívica e na geração da macroforma musical; b) uma investigação semiótica da paixão na música.

\section{ABSTRACT}

The dissertation named Analysis of the musical discourse: a semiotical approach discusses the application on musical analysis of the model championed by lithuanian linguist Algirdas Julien Greimas which conceives the process of generation of meaning as a path from abstract oppositions to narrative structures and hence to the discourse itself, which is called meaning generation path. The first chapter brings a general exposition which situates its analytical proposal in terms of the historical development of both musicology and the french branch of semiotical studies, which is committed with Structuralism. On chapter II, a detailed application of the theoretical model is presented step by step with the help of commented examples regarding some of the most appealing compositions of western repertory such as Beethoven's 5th. Symphony, Tschaikovsky's 4th Symphony and the first fugue of Bach's Well-tempered keyboard. The conclusion suggests that a semiotical approach on music should start with considering the superficial aspects of musical discourse so that its tensive and phorical course can be inferred and conceived as a complex of modulations where its internal relationships of attraction and repulsion may be ordinated in terms of valence. Based on the hypothesis of the existence of an instance of discreteness which converts the valences of the fundamental level into values of the narrative level and modulations into modalities, the study of narrative brings forth two main contributions. First, a semantical approach which explains the relationship between theme and musical form and revolutionizes the concept of musical variation. Second, a semiotical research on passion in music. 
1.1.2. O Nascimento da Teoria Musical e o Problema da Notação

pg. 6

1.1.3. A Teoria Musical no Medievo

pg. 7

1.1.4. A Ars nova e o surgimento do empirismo no ocidente

pg. 8

pg. 9

1.1.5. O Advento do temperamento

1.1.6. Schoenberg e sua teoria harmônica

1.1.7. O estruturalismo de Schenker

1.2. Evolução da semiótica francesa: de Saussure a Zilberberg

1.2.2. Greimas e a semiótica das paixões

1.2.3. Authier-Revuz e a heterogeneidade constitutiva

1.2.4. A contribuição de Zilberberg

pg.18

a. O tempo profundo

b. Valência/valor

pg.18

pg.19

1.3. A proposta de síntese: a semiótica e os sistemas semi-simbólicos

pg.22

2. Do percurso gerativo do sentido

$\operatorname{pg} .25$

2.1. A silabação enquanto fundamentação de uma leitura semiótica do discurso musical

2.2. Do nível profundo

2.2.1. Sintaxe profunda

2.2.2. Semântica profunda

a. Aspectualizações e modulações

pg.56

b. Da convocação ao nível discursivo

pg.63

2.3. Do nível narrativo

pg.66

2.3.1. Sintaxe narrativa: das transformações de estado ao fluxo de valores

2.3.2. Semântica narrativa: a paixão no discurso musical

a. Da modulação à modalização: categorização e aspectualização

b. A pedra de Rosetta: o caso da Sinfonia n.o 4 de Tchaikovsky 
i. Configuração modal dos actantes no texto verbal

pg.106

ii. Recursos e mecanismos discursivos do texto musical

pg.109

iii. Determinação da configuração modal pg.133

iv. $\quad$ Modalidades verbais $x$ modalidades musicais

pg.136

\section{Conclusão}

4. Fontes Bibliográficas

pg.142

4.1.1. Bibliografia

pg.142

4.1.2.

Musicografia

pg.147

4.1.3.

Multimídia

pg.147

4.1.4. Sites de pesquisa semiótica consultados via

pg.147 


\section{Introdução}

O modelo greimasiano de percurso gerativo, por apresentar-se desde sua origem como uma teoria do sentido, tem visto seu horizonte de aplicação se expandir enormemente nos últimos anos. Prestando-se inicialmente à análise de textos verbais, seu raio de alcance foi logo se estendendo primeiramente às artes visuais e, em seguida, à música. A semiótica musical é entretanto ainda um dos mais recentes ramos de pesquisa semiótica, e seu estágio atual de desenvolvimento concentra-se na obra de dois autores: Eero Tarasti e Luiz Tatit. O primeiro, em sua Sémiotique musicale, procura estabelecer os fundamentos de uma semiótica musical a partir não só da visão de Greimas mas também de outras correntes da semiótica, principalmente daquela centrada na obra de Peirce, além de absorver as contribuições da musicologia em seus mais recentes avanços. Já Tatit, limitando-se à linha greimasiana enriquecida pelas pesquisas de Zilberberg e atendo-se tão somente à análise da canção popular brasileira, aprofunda-se no estudo da relação entre a entoação do texto verbal da canção com seu contorno melódico, construindo um modelo teórico sólido e instigante que propõe a silabação enquanto perspectiva de abordagem semiótica do texto musical. Tendo como referência a obra desses dois grandes autores, procuraremos neste trabalho dar continuidade às pesquisas rumo a uma semiótica musical, focalizando nosso interesse na problemática relativa à aplicação do modelo de percurso gerativo do sentido à análise do discurso musical. Valendo-nos de textos relativamente simples, como É doce morrer no mar, de Caymmi, ou da complexidade da 5.a Sinfonia de Beethoven, procuraremos ilustrar ao máximo cada colocação teórica, permitindo assim a visualização imediata das idéias propostas e um mergulho em questões conceituais sem nos limitarmos à abstração especulativa.

A exposição teórica e analítica está organizada em dois grandes capítulos, contendo itens e sub-ítens: Apresentação e Do percurso gerativo do sentido.

O primeiro capítulo tem por objetivo oferecer um panorama históricoteórico da análise do discurso musical desde seus primórdios até seu encontro com a semiótica francesa. No item 1.1, Evolução da teoria musical: de Aristóxenus a Schenker, tem-se uma visão geral da evolução do pensamento teórico musical desde a Antigüidade, visão essa que, se bem que centralizada na vertente clássica ocidental, procura incluir e não minorar a importância do legado deixado pelos contatos do ocidente com outras civilizações, cada uma delas em sua época tão ou mais avançada que os europeus em suas investigações sobre a natureza do som e a estrutura do discurso musical. Focaliza-se ainda a grande transformação por que passa a teoria musical no ocidente desde um ponto de vista a priori da produção discursiva, ou seja, uma perspectiva especulativa mais preocupada com a natureza do som do que com sua colocação em discurso, até uma visão a posteriore, predominantemente empirista e baseada na prática musical registrada no repertório de cada época. O estruturalismo de Schenker, com sua herança schoenberguiana, é apresentado como elo de ligação que aproximou a teoria musical do pensamento lingüístico do século XX. No item 1.2, Evolução da semiótica francesa: de Saussure a Zilberberg, esboça-se uma genealogia epistemológica do pensamento greimasiano partindo da obra do lingüista suíço, passando pela contribuição de Hjelmslev e, apresentando em linhas gerais a 
proposta conceitual e metodológica de Greimas, prosseguindo rumo aos pósgreimasianos, dando-se destaque às contribuições de Authier-Revuz pelo estudo da heterogeneidade constitutiva do discurso, de Kristeva pela introdução no ocidente da obra do círculo bakhtiniano, integrando a questão da interdiscursividade à semiótica francesa, e de Zilberberg por suas pesquisas sobre o nível profundo do percurso gerativo. Por fim, no item 1.3, A proposta de síntese: a semiótica e os sistemas semi-simbólicos, apresentam-se as principais aplicações do modelo greimasiano de análise do discurso em textos não-verbais, destacando-se aí o pioneirismo de Floch com sua semiótica plástica e, na área musical, a semiótica musical de Tarasti e a semiótica da canção de Tatit.

No segundo capítulo, Do percurso gerativo, são expostas e discutidas as adaptações metodológicas requeridas pelo modelo greimasiano para sua aplicação no discurso musical. Divide-se em três itens, sendo que o de número 2.1 e 2.1 ocupam-se basicamente de questões relativas à estruturação do nível profundo, enquanto que o último é dedicado exclusivamente ao nível narrativo. Vejamos pois com maior detalhamento a organização de cada um desses itens.

No item 2.1, A silabação enquanto fundamentação de uma leitura

semiótica do discurso musical, explana-se de que maneira a silabação se manifesta na estrutura de uma música e de que maneira essa se semiotiza, constituindo um plano do conteúdo e caracterizando o texto musical como sistema semi-simbólico. O percurso teórico realizado é ilustrado através da análise da estrutura musical da canção É doce morrer no mar, de Caymmi. Na conclusão do tópico, chega-se às diretrizes metodológicas que nortearão o restante do trabalho. No item 2.2 , Do nível profundo, faz-se uma investigação minuciosa da estrutura do nível fundamental no discurso musical e do papel por ele desempenhado na economia do percurso gerativo como um todo, incluindo sua interrelação com os outros patamares da significação e algumas das principais diferenças notadas em relação à sua atuação no discurso verbal. No subitem 2.2.1, Sintaxe profunda, a organização dessa instância do nível fundamental é dissecada à luz da análise do primeiro e segundo tema do I movimento da 5.a Sinfonia de Beethoven. No sub-item 2.2.2, Semântica profunda, procede-se de maneira análoga, desta vez ilustrando o procedimento teórico com uma análise do início da Sonata Op.13 n.o 8, mais conhecida como Sonata Patética, de Beethoven. Pontuandose esses dois sub-ítens com as objeções de Hanslick a uma semântica musical, a necessidade de uma maior detalhamento levou à inclusão de dois tópicos em 2.2.2. No primeiro, Aspectualizações e modulações, expõe-se de que maneira as aspectualizações e modulações tensivas são convocadas à instância discursiva na música, e a identificação e análise dessas convocações é exemplificada através de sua detecção nos trechos iniciais da Suíte Aus Holberg's Zeit, de Edvard Grieg, e da Serenata para Cordas, de Tchaikovski. No segundo tópico, Da convocação ao nível discursivo, encerra-se nosso estudo do nível profundo através de uma avaliação das peculiaridades com que a convocação se apresenta na música e com um esboço metodológico de abordagem semiótica da análise do discurso musical no que tange à organização do nível fundamental e sua interação com os demais níveis do percurso gerativo.

O item 2.3, Do plano narrativo, divide-se em dois sub-ítens. O primeiro, 2.3.1, intitula-se Sintaxe narrativa: das transformações de estado ao fluxo de valores e apresenta a narrativa musical como seqüência de transformações de estado sofridas pelas estruturas actanciais do discurso em função do fluxo de valores que constitui a economia do sistema, transformações essas que podem envolver tanto 
relações mais simples, dizendo respeito exclusivamente ao estado juntivo de um sujeito com um dado valor, como também relações mais complexas de manipulação entre dois sujeitos, onde a atuação de um transforma a relação do outro com um certo valor. Dispondo a própria teoria musical de recursos para reconhecer e nomear muitas das transformações que ocorrem mais comumente em um dado repertório, principalmente no que diz respeito à chamada forma musical, propõe-se um estudo comparativo em que se confrontam a tradicional morfologia musical e a visão semiótica de percurso narrativo de algumas peças, buscando avaliar a compatibilidade e a complementaridade dos corpos teóricos. À guisa de ilustração das proposições acima, realizaram-se as análises dos primeiros compassos da Fuga I do Cravo bem temperado de Bach e de toda a exposição do I movimento da 5.a Sinfonia de Beethoven. O segundo sub-item, 2.3.2, intitula-se Semântica narrativa: a paixão no discurso musical, e subdivide-se em dois tópicos. $O$ primeiro, Da modulação à modalização: categorização e aspectualização, retomando a objeção de Hanslick, estabelece o embasamento teórico dentro da teoria semiótica para a fundação de uma perspectiva narrativa semântica para o discurso musical, baseando-se na postulação de uma instância discretizadora responsável pela conversão das modulações do devir já detectadas por suas convocações enquanto aspectualizações discursivas em modalidades, modalidades essas que condicionam o modo de existência de um dado sujeito e cuja sobreposição e aspectualização resulta no equacionamento dos estados patêmicos ou paixões. O segundo, A pedra de Rosetta: o caso da Sinfonia n.o 4 de Tchaikovski analisa o percurso patêmico do trecho de uma carta de Tchaikovski em que o compositor expõe a uma amiga íntima os sentimentos que quis expressar em sua quarta sinfonia e confronta a configuração passional resultante com o quadro modal a que se chega a partir da conversão em modalidades das modulações tensivo-fóricas detectadas por suas aspectualizações discursivas, finalizando-se com uma discussão em que se avaliam os resultados das hipóteses assumidas no sub-item anterior.

$\mathrm{Na}$ Conclusão, buscamos apresentar uma síntese metodológica que permita a aplicação do modelo de percurso gerativo do sentido na análise do discurso musical, apresentando soluções para as principais dificuldades teóricas com que se defronta o analista e salientando as contribuições que essa linha de análise tem a oferecer tanto para a própria semiótica quanto para a musicologia.

Finalmente, nas Fontes Bibliográficas, relacionam-se as principais obras de referência cuja consulta resultou numa contribuição direta (ou, em casos excepcionais, indireta) para este trabalho. Estão listados não só livros de pesquisadores, artistas e filósofos, mas também as partituras musicais analisadas e que integram o corpus desta dissertação, as fontes de consulta multimídia e os sites da internet pesquisados, a cuja valiosa contribuição se devem as referências mais atualizadas às obras de grandes semioticistas como Thomas Sebeok e Göran Sonesson. 


\section{Apresentação}

\subsection{Evolução da teoria musical: de Aristóxenus a Schenker}

\subsubsection{A Música na Antigüidade}

Se o papel do desenvolvimento da linguagem verbal no processo civilizatório parece, dentro de certos parâmetros, razoavelmente claro, dispondo ainda de documentação tal que propiciou alguma reconstituição do que tenha sido a língua oficial utilizada na alvorada do império egípcio, ou aquela outra utilizada pelos sumérios entre o IV e III milênios A.C., ou permitido a decifração das escritas Linear $A$ e $B$ grafadas em objetos da civilização Minóico-Micênica encontrados em Creta e datados do II milênio A.C., para não falar das próprias escritas egípcia, cuneiforme, etrusca e tantas outras; se a linguagem enquanto fenômeno pode ser vista como intrínseca à organização social, justificando-se a linguagem verbal enquanto resposta mais efetiva às necessidades básicas de comunicação de qualquer grupo humano; se o estudo da linguagem verbal conta hoje, em suma, com farto material de pesquisa sobre o qual se debruçar, além de ter atingido um grau de maturidade de reflexão que lhe possibilitou responder a algumas de suas questões fundamentais, a situação com a qual se depara o musicólogo é, em certos aspectos, desoladora. Gerald Abraham, na introdução à sua obra The concise oxford history of music ${ }^{1}$, expõe brilhantemente essa situação, comparando-a à adaptação de Walter Scott de Hamlet, em que o príncipe não aparece, sendo simplesmente descrito e comentado pelos demais personagens do drama. Aos olhos de Abraham, "he remains more immaterial than his father's ghost ${ }^{2 "}$. Essa seria a desconfortável posição do musicólogo perante quase toda a produção musical anterior à era cristã. Se os estudos arqueológicos possibilitaram, por exemplo, um levantamento detalhado dos instrumentos musicais utilizados no Alto Império Egípcio; das ocasiões em que os serviços dos músicos eram solicitados; do papel dos músicos na sociedade; das diferentes instrumentações utilizadas para cada ocasião; de algumas diferenças entre a música oficial e aquela praticada pelo povo nas ruas e aldeias; de como era feita a educação musical; de como eram organizados os corais; apesar de toda essa informação, a triste verdade é que o pesquisador pode apenas sonhar como o que possa ter sido essa música, ou aquela com a qual Davi, tocando a antiga lira hebraica, o kinnôr, expulsava os "demônios" do rei Saul, ou, numa perspectiva menos mitológica, com Sacadas de Argos, reputado como talvez o maior músico histórico da Grécia antiga (só perdendo para o legendário Orfeu, que teria sido capaz de aplacar a ira das feras com seu canto), levando multidões ao delírio em Delfos, no ano 586 A.C., expressando com seu aulos (algo como uma pequena flauta doce bifurcada) uma luta entre Apolo e um dragão.

A música, entretanto, ao que tudo indica, sempre esteve presente em qualquer organização social humana desde os primórdios da civilização. De fato, há diversas flautas feitas em ossos perfurados datadas do Neolítico, além do célebre desenho na caverna Magdaleniana de Les Trois Frères (Ariège), datado de 13.500 A.C., mostrando um caçador disfarçado de bisonte tocando um instrumento musical ainda hoje encontrado em tribos africanas. Com tantos indícios de sua presença e importância na sociedade, não há, entretanto, respostas sobre o por quê da música, a

\footnotetext{
${ }^{1}$ Abraham, 1988:2-6.

${ }^{2}$ Idem, p.2.
} 
definição de a qual necessidade humana ela efetivamente responderia. Houve, entretanto, ao longo de 6000 anos de civilização, duas grandes tentativas de abordar teoricamente essa questão, uma suméria e outra chinesa, ambas anteriores à era cristã (existe a possibilidade de que a chinesa, como a babilônia e a grega, descendam diretamente da investigação suméria), tentativas essas que, embora tenham chegado a propostas consideradas hoje um tanto quanto fantasiosas (ou, ao menos, inverossímeis) a respeito da relação entre a música e as leis que regem o universo em geral e a natureza humana em particular (crença essa transmitida dos sumérios aos babilônios, egípcios e gregos, em direção ao ocidente; persas, indianos, árabes e talvez chineses, no oriente), resultaram também em última análise no estabelecimento de determinadas convenções que regeram todo o desenvolvimento posterior da linguagem musical.

\subsubsection{O Nascimento da Teoria Musical e o Problema da Notação}

Atenhamo-nos agora à abordagem teórica suméria, que chegou à Grécia sob a forma do que passou a se chamar escola pitagórica. Pode-se sintetizar a contribuição da civilização Mesopotâmica para a linguagem musical no ocidente e oriente através de um único gesto fundador: a investigação a respeito da relação entre as proporções de um corpo em vibração e a altura do som resultante. Assim, as proporções 1:2, gerando o intervalo de oitava justa; $2: 3$, gerando a quinta justa; $3: 4$, gerando a quarta justa; 8:9, expressando um tom, o intervalo entre a quinta e a quarta, e, finalmente, o semitom, expressando o intervalo entre a quarta e dois tons, passaram a constituir o fundamento matemático da engenharia que regulou simplesmente toda a construção de instrumentos a partir dali. Surgiu nesse momento o próprio conceito da escala diatônica (e também da cromática e da utilização dos quartos de tom, ambos os procedimentos conhecidos por gregos e chineses, deduzidos a partir dos mesmos princípios supracitados) que, "reduzida" ao aparente pentatonismo da música chinesa ou "ampliada" pela utilização de quartos de tom resultando na divisão da oitava em 22 intervalos na música clássica indiana, passou a organizar o paradigma musical de quase todas as civilizações do mundo, valendo citar como exceções a música javanesa, conhecida como gamelão, onde a escala pentatônica resulta da divisão da oitava em cinco intervalos iguais, e a música de povos ditos primitivos, como os índios do Xingu, que, apesar de produzir engenhosamente instrumentos como as trompas amengon, as flautas yakui e kuluta-i e os clarinetes taquara, limitam a tessitura de cada um desses instrumentos a cerca de uma quinta justa e basicamente exploram quartos de tom envolvendo os intervalos de quarta justa, quinta justa, terça maior e segunda maior.

Sistematizada a escala musical, alguns milênios tiveram de se passar até os primórdios de uma notação musical. Há fortes indícios de que haveria uma notação musical já no antigo Egito, notação essa que teria partido de um código gestual para um gráfico, e sabe-se com certeza que os antigos gregos e chineses a tinham por volta do século IV A.C. No caso grego, Aristóxenus, discípulo de Aristóteles e autor do primeiro tratado de teoria musical conhecido no ocidente, por volta de 320 A.C., faz algumas referências à existência e emprego da notação musical de sua época, mas lamentavelmente não oferece subsídios para compreendê-la, ao que tudo indica partindo do pressuposto de que seus leitores certamente saberiam algo tão elementar. A dimensão do problema de decifrar a notação musical da antigüidade se faz ver em toda sua complexidade a partir da simples informação de que alguns 
sistemas baseavam-se na altura das notas, cada nota recebendo um nome, como nos sistemas atualmente utilizados na música ocidental, chinesa e indiana, outros indicavam movimentos ascendentes e descendentes a partir de uma nota fundamental, como as neumas que posteriormente evoluíram até se transformar no atual sistema de notação ocidental, enquanto que outros, ao que tudo indica a maioria na era pré-cristã, referiam-se simplesmente à posição das notas no instrumento, como a moderna tablatura. Tendo alguns instrumentos referenciais desaparecido por completo ou, no caso dos instrumentos de cordas, sendo um tanto quanto incerta sua afinação original, a tarefa chega às raias do impossível. Como se não bastasse isso, as notações musicais da antigüidade, quase sempre limitavam-se a designar as alturas das notas, sem referência nenhuma à sua duração. No caso dos gregos, árabes e indianos, tal se explica pelo fato de cada uma das formas musicais praticadas por esses povos dispor de modos rítmico-melódicos, ficando óbvio para um conhecedor que determinada melodia estaria associada a um dado padrão rítmico, determinando-se assim as durações das notas grafadas. Deve-se a Boethius, primeiro-ministro do imperador bizantino Teodorico, o tratado De Institutione Musica, do século VI D.C., que deu aos teóricos medievais os subsídios necessárias para decifrar alguns documentos musicais da antigüidade, em um intervalo que abrange documentos do século II A.C. ao século II D.C.. O sistema de notação chinês, já existente aparentemente no século IV A.C., não nos permite um conhecimento muito mais aprofundado que o ocidental apenas pelo fato de poucos documentos terem sobrevivido aos constantes holocaustos promovidos por imperadores interessados em "purificar" a cultura de seu país, como aquele realizado por ordem do último imperador da dinastia Ch'in, no ano de 212 A.C, do qual escapou, entretanto, o tratado de Lü Pu-wei, já contendo os fundamentos daquilo que viria a ser o pensamento musical teórico chinês, desenvolvidos subseqüentemente por Ching Fang em cerca de 40 A.C. até atingir os fundamentos acústicos da escala dodecafônica por semitons (à qual os gregos também já haviam chegado).

\subsubsection{A Teoria Musical no Medievo}

Foi Hucbald quem apontou em seu De Institutione Harmonica (e, ao que tudo indica, também no Musica Enchiriadis, tido como de autor anônimo mas possivelmente de sua autoria), já no século IX, para a transformação na linguagem musical ocidental responsável por sua singularidade dentre todas as outras culturas: o advento da polifonia. A polifonia pode ser definida como a simultaneidade de melodias claramente distintas que se combinam entre si, fundindo-se numa única composição. Nas músicas chinesa, árabe e indiana, como na grega antiga, observa-se a heterofonia, que consiste na prática da entoação simultânea de uma mesma melodia de forma ligeiramente variada em cada instrumento. Assim, na mesma época em que os estudiosos árabes consolidavam os fundamentos teóricos e estilísticos de sua música no Kitab-al-aghani al-kabir (Grande livro de canções) de Al-Isfahani (897967) e no Risala fi'l musiqi (Tratado musical ${ }^{3}$ ) de Ibn al-Munajjim (c. 912), os monges medievais faziam o mesmo com o embrião da música ocidental. Vale aqui ressaltar como um dos fatores responsáveis por essa absoluta singularidade no

\footnotetext{
${ }^{3}$ É sintomático aqui o uso da palavra de origem grega, musiqi, e não o termo árabe, ghina, denunciando a notável absorção da cultura grega pela árabe, o que possibilitou posteriormente sua reintrodução no ocidente, onde estava em sua maior parte perdida. Particularmente, o próprio De Institutione Musica de Boethius, em que se baseou Hucbald, chegou ao ocidente pelos árabes.
} 
desenvolvimento da linguagem musical no ocidente um fator tecnológico: a difusão do órgão. Descendendo diretamente do hydraulos grego que se difundiu de maneira notável no império romano do início da era cristã, o órgão fazia parte de um esforço da igreja para atrair fiéis através de manifestações culturais de caráter popular, como representações de caráter teatral da história sagrada, festas e música. Sabe-se que o órgão era um instrumento profundamente popular, utilizado freqüentemente no circo e tendo o problema de sua imobilidade resolvido por um variante seu remotamente (sob o ponto de vista cronológico) aparentado com a atual gaita de foles e o atual acordeon. O órgão foi o primeiro instrumento a possibilitar efetivamente ao instrumentista a produção de duas ou mais melodias simultâneas, de tal forma que a execução de uma única voz pura e simplesmente chega a parecer antinatural, por deixar uma das mãos inteiramente inativa. O crescimento vertical, harmônico, da música ocidental teve porém como contrapartida a necessidade da castração da liberdade melódica do intérprete. Para ilustrar melhor essa questão, vale ressaltar que nas músicas árabe e indiana, por exemplo, a improvisação realizada pelo intérprete é de uma importância tal que só encontra equivalência no ocidente no jazz do século XX. Além disso, a utilização de microtons é essencial como recurso expressivo. Esses dois aspectos são de certa forma inviáveis no contexto polifônico seguido pelo ocidente, que requer o cálculo preciso de cada voz para resultar na alternância entre consonância e dissonância em seus variados graus que é a responsável pelo fluxo narrativo do discurso. Diante dessa necessidade técnica, desenvolveu-se gradativamente no ocidente ao longo de um período de mais de mil anos a mais complexa forma de grafia musical conhecida, visando dar conta da necessidade de organização do material sonoro vital à realização do ideal polifônico inaugurado enquanto práxis já no século IX.

Convém por último lembrar que a herança pitagórica (na verdade de origem sumério-babilônica) foi herdada por Hucbald através de Boethius, e a concepção fundamentalmente matemática que a permeia foi a responsável pela inclusão da música no quadrivium, juntamente com a aritmética, a geometria e a astronomia. A música das universidades medievais (que perdurou no currículo até o século XVIII) era vista não enquanto práxis estética, mas como ilustração prática de propriedades físicas e matemáticas, o que motivou grandes matemáticos como Descartes, em seu Compendium musicae de 1618 a pesquisarem e escreverem tratados musicais dentro dessa perspectiva.

\subsubsection{A Ars nova e o surgimento do empirismo no ocidente}

$\mathrm{Na}$ alvorada do século XIV, a música ocidental registrou sua segunda grande revolução, documentada pelo tratado Ars nova, de Philippe de Vitry. Foi a partir da Ars Nova que todas as conquistas técnicas relativas à viabilização da polifonia, ou seja, o aprimoramento da notação viabilizando uma complexidade crescente do texto musical e o estudo das possibilidades estéticas da harmonia, num processo paralelo à transformação da ordem político-social vigente, sublevaram-se contra a dominação das diretrizes da igreja, resgatando uma mundaneidade, um espírito crítico e uma ousadia estilística há muito afastados da prática da música culta. $\mathrm{Na}$ bula "Docta Sanctorum", o papa João XXII, no ano de 1324, condena veementemente a nova prática musical, queixando-se de sua 
excessiva liberdade rítmica, buscando novas sonoridades, criando suas próprias músicas ao invés de cantarem as antigas... ornamentando, inserindo novas vozes nas músicas tradicionais, por vezes utilizando-se de um linguajar vulgar... ${ }^{4}$

De fato, as queixas do papa eram muito bem fundadas. A partir da Ars nova, a palavra, antes soberana, passa a mero pretexto, inspiração para a música, perdendo freqüentemente totalmente sua inteligibilidade em meio a contrapontos intrincados ou à simultaneidade de letras diferentes. Nos motetos, era freqüente que o cantus firmus fosse um fragmento de canto gregoriano, enquanto que as outras vozes contrapunham a ele melodias cuja letra falava de temas amorosos, satíricos e até mesmo escatológicos ou pornográficos. Além disso, a textura rítmica e melódica passou a complexificar-se extraordinariamente, denotando o surgimento de uma verdadeira autonomia no processo de evolução da linguagem musical, que a partir desse momento torna-se cada vez mais independente da palavra, resultando num processo gradativo que conduzirá em alguns séculos a um predomínio da música instrumental sobre a vocal.

Quanto ao tratado Ars nova, deve-se ressaltar sua importância ainda num outro aspecto por demais relevante: pela primeira vez no ocidente (Al-Isfahani e Ibn al-Munajjim já possuíam essa preocupação no século $\mathrm{X}$ ), um grande tratado musical é escrito dentro de uma abordagem empirista, e não científico-especulativa. Assim, o que interessa a Vitry é não mais debruçar-se sobre o paradigma sonoro, mas, desse ponto em diante, a ênfase se deslocará para uma abordagem do paradigma musical e de sua organização sintagmática, sobretudo no que tange à morfologia do discurso musical.

A terceira grande revolução no pensamento musical surge com o Traité de l'harmonie $e^{5}$, de Rameau, publicado em 1722. Trata-se da primeira obra de peso na literatura mundial a abordar com profundidade a questão da harmonia enquanto resultante de três ou mais sons distintos simultâneos. No Livro I do Traité du rapport des raisons et proportions harmoniques, a partir da visão matematicista pitagórica, Rameau desenvolve uma assombrosa teoria capaz de analisar os graus de dissonância e consonância de uma acorde a partir de proporções harmônicas e, através de uma engenhosíssima aplicação do conceito de média harmônica, lança os fundamentos necessários para a concepção de uma harmonia baseada em acordes de quatro ou mais sons, quando em sua época predominavam os acordes de três sons, ou tríades. Entretanto, a bem da verdade, os fundamentos matemáticos da teoria de Rameau, apesar de serem capazes de dar conta de todo o comportamento harmônico do jazz do século XX, jamais tiveram muita repercussão, isso basicamente por duas razões: primeiro, pelo fato de que os músicos, a partir de sua época, já eram predominantemente empiristas preocupados essencialmente com a práxis musical, e não com concepções teóricas que justificassem e analisassem essa prática; segundo, porque a matemática já deixara de ser parte integrante do ensino de música, e os procedimentos de cálculo de Rameau não são triviais. Entretanto, para alegria de seus contemporâneos, seguem-se ao Livro I do Traité de l'harmonie o Livro II, De la nature et de la propriété des accords et de tout ce qui peut servir à rendre une musique parfaite; o Livro III, Principes de composition; e, finalmente, o Livro IV, Principes d'accompagnement, leitura obrigatória ainda hoje para aqueles que se dedicam ao estudo e à prática da música barroca em geral e do baixo contínuo em

\footnotetext{
${ }^{4}$ Abraham, 1988:117.

${ }^{5}$ Rameau, 1971.
} 
particular. A notável versatilidade desse músico francês (Rameau, além de teórico brilhante, foi também um dos maiores compositores de seu tempo) mostra-se assim tanto por sua profundidade especulativa quanto pelo domínio da linguagem musical de sua época e, ainda além, por sua clareza didática, somando-se todos esses fatores numa obra que é indiscutivelmente um dos grandes clássicos da teoria musical.

\subsubsection{O Advento do temperamento}

A escala diatônica original, baseada nos primeiros termos da série harmônica e nos intervalos entre eles, era construída de tal forma que o intervalo entre as notas Mi e Fá de uma escala de Dó maior era diferente do intervalo entre as mesmas notas numa escala de Fá maior. Esse tipo de discrepância, irrelevante para certas prática musicais, como a da música modal, causa problemas técnicos consideráveis ao se passar para uma concepção tonal. Enquanto no modalismo o centro harmônico aparece freqüentemente explícito no bordão, o tonalismo constituise sobre uma dialética em que o centro é inicialmente afirmado, em seguida negado através da contraposição a outro centro tonal (geralmente, a dominante, no caso da música clássica ocidental), instaurando uma polêmica (onde há contraposição a centros tonais ainda mais distantes que a dominante) ao fim da qual a tônica é reafirmada. Acontece que as irregularidades listadas acima tendem a tornar os acordes distintos da tônica tão mais assimétricos quanto mais distantes do centro tonal, o que representa uma dificuldade para a concepção tonal, que requer a ilusão da mudança de centro, a modulação. A solução que viabiliza a tonalidade em toda sua potencialidade representa um salto técnico e tecnológico de grandes proporções: a mudança definitiva de todo o paradigma diatônico (onde os intervalos são desiguais, sendo mais próximo da escala "natural") para um paradigma cromático (onde os intervalos são ligeiramente alterados para se tornarem todos iguais, constituindo uma mudança na alteração de todos os intervalos, menos os de oitava). Para se ter uma idéia do que representa esse salto, basta lembrar que trata-se de uma mudança na afinação da escala inteira, ou seja: a nova escala, a cromática, soava totalmente desafinada para os ouvidos acostumados ao paradigma diatônico. Assim, é curioso pensar que a organização sintagmática da práxis tonal implicou uma reorganização total de seu eixo paradigmático. Quanto à solução técnica em si, que foi convencionar o intervalo de semitom como raiz 12 de 2 , sua primeira formulação completa de que se tem notícia encontra-se, surpreendentemente para ocidentais acostumados a desdenhar o pentatonismo das escalas orientais, no tratado de teoria musical Yuëh-lü ch'üan shu, datado de 1606 e de autoria do príncipe chinês Tsai-yü. No ocidente, embora o temperamento fosse uma tendência já a partir de 1500, não havia para ele uma formulação teórica clara, sendo feito de maneira intuitiva por músicos e afinadores, datando o início de sua adoção já em sua forma matemática apenas a partir do século XVIII, tendo como uma de suas obras pioneiras o Cravo bem temperado de J.S. Bach, e consolidando-se seu uso apenas depois de 1850. Não há como exagerar a importância do advento do temperamento para o desenvolvimento da música ocidental, à medida que condicionou inteiramente o próprio tonalismo, inviável sob outras circunstâncias, e também por se tratar de uma explicação bastante consistente para a "pouca ousadia" no campo harmônico de vários compositores (com nobres exceções, como Gesualdo, na música vocal do seicento, e Bach, em sua música instrumental do settecento) até o século XVIII. De fato, um acorde de Mi bemol menor, na escala diatônica de Dó maior, soava absolutamente desequilibrado e 
desafinado, constituindo um corpo estranho de tão difícil integração à linguagem musical de sua época, que apenas com o advento do temperamento e com a conseqüente anulação de suas dissonâncias (ou seja: não houve solução real, e sim, um contorno do problema) foi possível sua incorporação ao sistema e, decorrente de sua assimilação, uma expansão da lógica tonal que possibilitou a exploração dos limites da tonalidade até sua virtual dissolução na atonalidade ou nas tonalidades errantes de Wagner.

\subsubsection{Schoenberg e sua teoria harmônica}

As extraordinária complexificação sofrida pela linguagem musical ocidental do século XVIII aos primórdios do século XX defasou em muito o pensamento teórico da prática musical (pois, como foi visto, a seção em que Rameau dá subsídios para a interpretação de harmonias de maior grau de complexidade é apresentada dentro de uma perspectiva essencialmente matemática, incompreensível para a maior parte dos músicos do século XIX), o que criou a necessidade de um modelo capaz de justificar e interpretar tais transformações. Arnold Schoenberg contou certa vez em uma aula na Universidade de Los Angeles um episódio ocorrido em sua juventude, numa época em que ele, já um compositor "maldito" de algum renome, teve de servir ao exército alemão. Um oficial, ao fazer a chamada, interpelouo: "Então, o senhor é Arnold Schoenberg?"; Schoenberg respondeu: "Sim, senhor. Alguém tinha de sê-lo. Ninguém queria sê-lo. Então, eu deixei que fosse eu". Ao lançar-se à difícil tarefa de conceber um modelo teórico capaz de dar conta das características da música de seu tempo, o compositor alemão consolidou um método exaustivo de análise harmônica, classificando termo a termo do discurso tonal, numa abordagem semelhante à de Benveniste ao mergulhar em cada termo da frase. Com isso, pôde especificar os procedimentos discursivos que diferenciavam os estilos de diversos compositores em particular, chegando posteriormente a um modelo historicista, amplamente difundido por seu discípulo Anton Webern em seu $O$ caminho para a música nova ${ }^{6}$, que propunha uma visão do desenvolvimento da linguagem musical enquanto assimilação gradual das dissonâncias ou, mais especificamente falando: pela incorporação ao discurso de cada um dos termos ímpares da série harmônica, partindo do 3.0 na idade média para o 5.0 na renascença, assimilando então o 7.0 no barroco, o 9.0 no romantismo e assim progressivamente até atingir a assimilação plena, que constituiria, na visão schoenberguiana, o dodecafonismo (Seria mais coerente matemática e acusticamente supor que isso causasse o fim do temperamento, pois os harmônicos a partir de 13 não se ajustam mais à escala temperada. Por essa lógica, haveria uma transformação no conceito de afinação, conduzindo a uma ampliação da escala temperada ocidental, que reconhece 12 subdivisões no intervalo de oitava, para algo por exemplo como a escala da música indiana, que reconhece 22 subdivisões no mesmo intervalo, ou mesmo para a adoção em definitivo de outros modelos ocidentais de origem pitagórica, como aquele que reconhece no intervalo de oitava 35 subdivisões: os 7 graus naturais, os 7 bemóis, 7 sustenidos, 7 dobrados bemóis, 7 dobrados sustenidos). Schoenberg costumava dizer a seus alunos que sua proposta estética dodecafônica garantiria a supremacia da música alemã por mais mil anos, utilizando-se nessa expressão de uma fórmula discursiva bastante comum na primeira metade do século XX. Pode-se comparar o ideal do

\footnotetext{
${ }^{6}$ Webern, 1984.
} 
teórico alemão a um lingüista que, partindo de certas expressões utilizadas na fala cotidiana e de um modelo do processo lingüístico que as gerou, escrevesse poemas utilizando-se de extrapolações daquela nova "linguagem" e pregasse que ela perduraria por um milênio. Trata-se evidentemente, hoje, de uma temeridade. Não pareceu em sua época. Schoenberg marcou assim profundamente o pensamento teórico musical e estético deste século.

\subsubsection{O estruturalismo de Schenker}

A teoria musical, ao abandonar o enfoque acústico-matemático em prol do empirismo, viu-se fragmentada numa plêiade de disciplinas, como contraponto, harmonia, morfologia, história da música etc., cada qual com seu próprio escopo e abordagem específica, guardando cada ramo pouca ou nenhuma relação aparente com as demais áreas do conhecimento musical. Foi apenas a partir da obra de Heinrich Schenker (1868-1935) que todas as matérias foram mobilizadas de maneira coerente e consistente visando compor um modelo que explicasse o funcionamento do discurso musical. Em suas pesquisas como analista, Schenker, discípulo de Bruckner, destacado compositor alemão cuja especialidade era a criação de obras de grandes dimensões e extraordinária complexidade estrutural, vislumbrou na consideração da estrutura musical o enfoque capaz de descrever o percurso gerativo do discurso musical (sua preocupação com o sentido foi puramente de ordem sintática; discípulo de Hanslick, Schenker não ousou buscar os fundamentos de qualquer forma de semântica musical). Assim, analisando o repertório ocidental de Bach até Brahms, o teórico austríaco foi capaz de reconhecer uma organização sintática da qual se podem traçar alguns paralelos com o modelo proposto por Greimas (embora, ao que tudo indica, Schenker desconhecesse a perspectiva estruturalista de Saussure). Quanto à sintaxe profunda, Schenker propõe uma visão do discurso musical enquanto dialética entre tensão (acorde de dominante) e relaxamento (acorde de tônica) e, embora não chegue a compor um quadrado semiótico, reconhece uma função harmônica basicamente neutra ou, eventualmente, de afastamento (acorde de subdominante), ocupando ora a posição de intensão, ora a de distensão. Vale ressaltar quanto ao aspecto semântico de nível profundo que, embora o modelo schenkeriano evite a todo custo discussões a respeito da foria, há uma avaliação tácita da tensividade em seu trabalho através da herança deixada pela obra de Schoenberg, onde está implícito um estudo detalhado das tensões harmônicas. As categorias de nível profundo se convertem em valores narrativos tonais, determinando-se as mudanças de estado de coisas a partir de um percurso comum que o austríaco, analogamente ao procedimento de Propp, reconheceu como a estrutura básica do repertório ocidental dentro do período de 200 anos entre os séculos XVII e XIX: o estado de conjunção com o valor tonal de tônica, (o primeiro grau da tonalidade, tradicionalmente grafado como $I$ ), a troca desse valor pelo de dominante $(V)$, passando antes ou depois por um estágio de afastamento da polarização através da aquisição do valor de subdominante $(I V)$ e a reconquista final da tônica, sancionando a polaridade. Conforme já explicado, esse modelo despreza (na acepção matemática do termo) as implicações semânticas do percurso narrativo e a problemática do estudo dos efeitos de sentido passional gerados pela música. Quanto à conversão dos valores narrativos ao plano discursivo, para melhor clareza de exposição, vamos nos ater à forma sonata, a mais importante do período analisado. No caso do nível de superfície, e apenas nesse caso, temos uma inversão sob o ponto de vista semiótico da abordagem sintática aprioristicamente 
adotada por Schenker. No plano discursivo, o teórico austríaco basicamente abandona as questões concernentes à sintaxe (exceto pelo fato de poder-se considerar, no caso do discurso musical, haver uma coincidência entre actante e agente temático) Pode-se deduzir do modelo schenkeriano que, para ele, os valores narrativos são tematizados no discurso da seguinte maneira: o valor de tônica é tematizado naquilo que a teoria musical chama, numa feliz coincidência de terminologias, de I Tema; o valor de dominante discursiviza-se através do II Tema; os eventos correspondentes às gradações tensivas discretizam-se por dupla conversão ou por convocação através dos temas referentes àquilo que a morfologia musical classifica como coleta, coda, ponte e episódio.

Embora seja de certa forma injusto expor o modelo de Schenker de maneira tão resumida, deixando de lado algumas de suas conquistas metodológicas e conceituais, ficam assim até certo ponto patentes suas principais limitações no nível semântico e, por outro lado, suas extraordinárias conquistas enquanto modelo teórico, organizando um estado previamente caótico da análise do discurso musical, estado esse totalmente carente de uma concepção capaz de dar unidade e coerência às várias subdisciplinas que pulverizavam o texto musical em fragmentos estruturais sem qualquer visão de seu próprio papel na constituição do discurso musical em si e no processo de geração de sentido cujos fundamentos Schenker vislumbrou e levou tão longe quanto a episteme de sua época lhe permitiu chegar.

\subsection{Evolução da semiótica francesa: de Saussure a Zilberberg}

Quod superius, sicut inferius ${ }^{7}$.

\subsubsection{Introdução}

Hermes Trismegisto

Coube a Ferdinand de Saussure o mérito de conduzir o foco de atenção da lingüística de uma perspectiva geralmente histórico-comparativa (ou fonética, no caso das pesquisas realizadas por seus contemporâneos na Inglaterra) para uma outra capaz de conduzi-la ao estatuto de ciência da linguagem consolidada ao mesmo tempo no relativo pragmatismo de sua proposta de silabação em relação às concepções fonéticas de seus contemporâneos, na dinâmica conceitual em que apresenta sua visão de langue e, finalmente, no alcance teórico/especulativo de suas propostas. Esse último aspecto foi captado em toda sua profundidade por Hjelmslev, que soube ver por detrás das proposições à primeira vista recebidas como quase empiristas do autor do Cours de linguistique générale os fundamentos através dos quais se viabilizaria o projeto de uma semântica estrutural cuja importância posterior no desenvolvimento da semiótica francesa não pode ser exagerada.

A visão saussuriana teve notável repercussão no mundo acadêmico da primeira metade do século XX, resultando, por Benveniste, na fundação de uma semiologia que se propagou pela obra de Barthes e que, ultrapassando o domínio da lingüística, viu evidenciada sobretudo através de sua aplicação na obra de LéviStrauss sua vocação epistemológica, caracterizando-se a partir daí o estruturalismo quase como uma ciência em si (alternativamente, uma metodologia ou, indo além, uma postura filosófica) a organizar as demais ciências humanas. Não se deve perder

\footnotetext{
${ }^{7}$ Schuré, 1986:71
} 
de vista, entretanto, a filiação do estruturalismo ao próprio comparativismo que suplantou, à medida que sua semente já era detectável no próprio procedimento analítico de comparação gramatical entre as línguas indo-européias, recuperando-se assim sua relação com os trabalhos de Bopp, Bréal e Meillet.

Levando adiante determinados preceitos implícitos na obra de Saussure, Hjelmslev, ao desenvolver seu projeto de uma semântica estrutural, convenceu-se da existência de uma correlação entre a organização dos planos da expressão e do conteúdo, dando com essa proposta o grande passo que possibilitou a fundamentação de uma semiótica enquanto teoria geral do sentido, sem restrições apriorísticas quanto à natureza dos signos integrantes do sistema. Assim, o mestre dinamarquês, partindo das categorias da expressão detectadas por Saussure no processo de silabação, soube ver, tal qual Propp, uma estrutura da linguagem que em absoluto não se restringiria à singularidade dos casos estudados, nelas vislumbrando uma organização do próprio processo de significação, independentemente, portanto, da natureza de seu plano de expressão, fosse ele verbal, gestual, plástico, coreográfico etc. A partir de Greimas, a hipótese de analogia entre os dois planos proposta pelo autor dos Prolegômenos passa a constituir-se como o fundamento de uma teoria semiótica cuja ênfase reside não num inventário e avaliação do repertório de signos presentes em um texto (não necessariamente verbal), enfoque esse predominante na semiótica peirceana, mas sobretudo em uma investigação do processo de geração de sentido que provê em última análise o estatuto semântico necessário à assunção pelo próprio texto como um todo do status de signo complexo. Para atingir sua meta, Greimas criou uma metodologia de investigação dos mecanismos de geração de efeitos de sentido em um texto, concebendo seu modelo teórico através da elaboração de um simulacro do processo de construção de sentido, por ele denominado percurso gerativo. Assim, por percurso gerativo de sentido entende-se o simulacro teórico que estuda a construção dos efeitos de sentido de um texto da concretude e complexidade da manifestação de seu plano de expressão à abstração e simplicidade de seu plano do conteúdo, concebendo-se assim uma abordagem do texto através de três patamares de abstração crescente do plano do conteúdo: o nível discursivo, onde se apresentam as relações entre espaço, tempo e individualidade, e entre o discurso em si e o mundo natural; o nível narrativo, onde se estudam sintaticamente as mudanças de estado de coisas e semanticamente as mudanças dos chamados estados de alma; e, finalmente, o nível profundo, onde se atingem as oposições conceituais e tensivo-fóricas fundamentais cujo desdobramento subsume toda a dinâmica do texto. Em linhas gerais, o percurso de geração do sentido cruza os três patamares do plano do conteúdo da seguinte maneira: as categorias do plano profundo são assumidas em sua dialética enquanto valores do discurso, adquirindo a dimensão polêmica das transformações de estado no plano narrativo. Já essas transformações, quando assumidas por um enunciador e conseqüentemente actorializadas, espacializadas e temporalizadas, ao passo que os valores discursivos se figurativizam e tematizam, constituem em última instância o nível discursivo. A análise do sentido segue assim um percurso onde um fluxo contínuo conduz do conceito à materialidade do texto.

\subsubsection{Greimas e a semiótica das paixões}

Apesar de toda a engenhosidade do modelo de percurso gerativo, possivelmente a contribuição mais original do corpus greimasiano (à medida que a metodologia vista até o momento encontra precedentes no modus operandi 
estruturalista) reside em seu estudo a respeito dos estados de alma e de suas transformações, sintetizada em sua obra intitulada Semiótica das paixões. Com a contribuição de seu discípulo e colega Jacques Fontanille, Greimas desenvolve nesse trabalho os fundamentos para uma investigação da geração de efeitos de sentido passional, partindo para isso de uma reflexão a respeito da transição que conduz das instâncias da pré-significação à significação em si através de uma proposta onde a significação é vista como efeito resultante da discretização de um continuum tensivofórico à proto-materialidade das aspectualizações e modulações tensivas. As transformações e descontinuidades da tensividade-foria passam assim a se relacionar com as categorias representadas pelo quadrado semiótico de forma a fundar uma semântica do nível profundo, instaurando desde o nível profundo o germe da sensibilização necessário a qualquer desenvolvimento de um estudo das paixões coerente com o modelo de percurso gerativo desenvolvido até então. Enquanto a conversão das categorias fundamentais à condição de valores rege todas as transformações de estado de coisas do nível narrativo, o mesmo processo conduz as aspectualizações incoativa, cursiva, terminativa e pontualizante das modulações à condição de valores modais, cuja sobreposição determina o percurso de aquisição de competência do sujeito na mesma instância em que resulta enquanto efeito de sentido na geração de estados patêmicos atribuídos ao discurso em geral e ao próprio sujeito em particular. Assim, a Semiótica das paixões, através do equacionamento modal, debruça-se sobre um inventário léxico de estados anímicos resultantes da aquisição de competência modal pelo sujeito, estudando em especial as paixões do ciúme e avareza, mas sobretudo fornecendo subsídios para a extensão desse estudo a um semnúmero de outros estados patêmicos comumente produzidos em textos poéticos ou descritivos, literários ou não-verbais.

Apesar do enfoque passional do modelo greimasiano justificar-se através do nível fundamental para em seguida centrar-se sobretudo na dimensão narrativa do texto, as questões relativas ao nível discursivo não deixam de estar conceitualmente presentes, tendo continuidade seu desenvolvimento e aprofundamento sobretudo pelas mãos dos discípulos de Greimas, especialmente o próprio Fontanille e Claude Zilberberg. Esses dois, além de mergulhar na problemática da convocação das aspectualizações ao nível discursivo, publicaram recentemente nos Nouveaux actes sémiotiques ${ }^{8}$ um notável trabalho a respeito da conversão das valências em valor que lança uma luz sobre as relações entre valência, valor e isotopias (quer sob a forma de percursos temáticos ou figurativos) capaz de elucidar alguns pontos sem chegar a abalar os fundamentos da teoria já que, nas palavras do próprio Greimas,

Uma teoria semiótica que se concebe como percurso, isto é, como disposição hierárquica dos modelos que se implicam uns nos outros e pelos outros, deve constantemente interrogar-se sobre esse percurso, considerado como atividade de construção (...) Uma teoria com objetivo científico, nessas condições, fica permanentemente alerta às próprias lacunas e falhas, a fim de preenchê-las, retificálas. O edifício teórico não pode ser construído, por esse aspecto, num gesto fundador acompanhado de uma série de deduções teoremáticas: uma descoberta localizada na superfície do texto, uma inconsistência que aí se perceba não deixam de ressoar em profundidade na teoria e provocar perturbações, suscetíveis de questionar a economia do percurso gerativo em seu conjunto ${ }^{9}$.

\footnotetext{
${ }^{8}$ Fontanille \& Zilberberg, 1996.

${ }^{9}$ Greimas \& Fontanille, 1993: 9.
} 


\subsubsection{Authier-Revuz e a heterogeneidade constitutiva}

Deve-se sobretudo a Kristeva a introdução dos conceitos desenvolvidos pelo círculo bakhtiniano a respeito da análise do discurso, posições essas à primeira vista aparentemente inconciliáveis com um modelo fundado em preceitos estruturalistas. Em verdade, o próprio Bakhtin, em sua crítica ao formalismo, dirigia-se especificamente à abordagem saussuriana e benvenistiana, onde o sujeito se apossa da língua no momento da enunciação para realizar e estruturar seu discurso. Para Bakhtin, o texto era antes de mais nada o resultado de uma interação entre diferentes discursos representando os diversos estratos de uma sociedade em seu perpétuo conflito de interesses. $O$ discurso passa a definir-se assim como a arena da luta de classes, onde cada signo vem carregado de um valor social implícito:

La langue nationale se stratifie en dialectes sociaux, en maniérismes d'un groupe, en jargons professionnels, langages de genres, parlers des générations, des écoles, des autorités, cercles et modes passagères, en langage des journées (voir des heures) sociales, politiques (chaque heure possède sa devise, son vocabulaire, ses accents). ${ }^{10}$

Fundando assim o conceito de interdiscursividade, segundo o qual a análise do sentido de um texto passaria inevitavelmente pela identificação dos discursos que nele se digladiam e por uma avaliação de suas implicações sociais e ideológicas, Bakhtin desenvolveu conceitos fundamentais para o estudo da heterogeneidade constitutiva do discurso, como a polifonia, conceito emprestado da teoria musical relacionado à pluralidade de vozes distintas e freqüentemente antagônicas que compõe a instância discursiva; a carnavalização, textura polifônica onde uma subversão e/ou re-hierarquização dos valores estabelecidos socialmente criam um efeito de transgressão e humor associado em primeira instância pelo autor às festas medievais patentes na obra de Rabelais, por ele analisada; e o monologismo (oposto ao dialogismo constitucional do discurso), onde as marcas da alteridade são apagadas, resultando num discurso autoritário que se apresenta como portador da "verdade" científica, religiosa ou ideológica.

Também a obra de Freud foi alvo da crítica bakhtiniana. Para o lingüista russo,

L'homme ne possède pas de territoire intérieur souverain, il est entièrement et toujours sur une frontière; en regardant à l'intérieur de soi, il regarde dans les yeux d'autrui ou a travers les yeux d'autrui ${ }^{11}$.

Entretanto, a aparente incompatibilidade entre o ponto de vista de Bakhtin e a psicologia caiu por terra com as pesquisas psicanalíticas de Lacan, cuja linha de trabalho centrou-se numa análise da personalidade neurótica, caracterizada por um estado de cisão (especialmente no caso da esquizofrenia), a partir das marcas dessa ruptura especialmente no discurso verbal de seus pacientes (sinais corporais passaram posteriormente a ser igualmente relevados), tornando-se célebre seu estudo a

\footnotetext{
${ }^{10}$ Bakhtin, 1970: 88.

${ }^{11}$ Todorov, 1981:148.
} 
respeito dos atos-falhos. Na síntese entre essas duas linhas de pensamento dentro de uma perspectiva semiótica consiste o cerne da pesquisa de Jacqueline Authier-Revuz que, em seu Hétérogénéité montrée et hétérogénéité constitutive: éléments pour une approche de l'autre dans le discours funda e desenvolve o conceito de heterogeneidade constitutiva, incorporando à semiótica pós-greimasiana toda uma construtiva crítica à abstração conceitual do estruturalismo, resumida nas palavras de Robin:

Esta liberdade atribuída ao domínio da fala inscrevia-se numa Filosofia do sujeito neutro, transparente a si próprio (uma filosofia de antes da descoberta freudiana), e naquela de um sujeito sem determinações sócio-ideológicas (uma Filosofia de antes de Marx) ${ }^{12}$.

Sobretudo a partir dessas reformulações, a semiótica francesa se insere atualmente sobretudo em um pós-estruturalismo, à medida que mantém sua filiação com a obra saussuriana ao mesmo tempo em que, lembrando a citação de Greimas em item anterior, permanece atenta a suas próprias lacunas e, sinal de maturidade, constituiu-se num sistema capaz de absorver o impacto das críticas, assimilando sua contribuição sem haver comprometimento da coerência de um modelo cujo evolução se deve a uma pluralidade de pesquisadores e, conseqüentemente, a uma histórica busca de denominadores comuns dentro de uma multiplicidade de pontos de vista igualmente consistentes.

Assim, em síntese, sobretudo a partir dos trabalhos de Authier-Revuz, a pesquisa semiótica passou de um enfoque exclusivo centrado no texto para um enfoque inclusivo atento ao contexto onde aquele se insere, passando a admitir na intertextualidade um fator imprescindível à análise do discurso.

\subsubsection{A contribuição de Zilberberg}

Ao discutir a instância da pré-significação na Semiótica das paixões, Greimas e Fontanille abriram um leque de pesquisa abrangendo as modulações do devir e as aspectualizações da tensividade-fórica, não só pelo ineditismo da pesquisa como também por não terem esses elementos, da mais alta pertinência na investigação do sentido nos sistemas não-verbais, tido o devido espaço de aprofundamento nessa obra, cujo objetivo era não um mergulho nas questões do nível profundo, mas uma análise detalhada do plano narrativo em sua perspectiva semântica. Dentre os continuadores da exploração dos mecanismos de geração de sentido do plano profundo, destaca-se a obra de Claude Zilberberg. Além de reavaliar o papel da silabação no percurso gerativo a partir dos estudos realizados nessa área por Saussure e Hjelmslev, criando os alicerces para a extensão da pesquisa semiótica rumo aos sistemas semi-simbólicos, Zilberberg reviu e deu continuidade às investigações a respeito do papel da tensividade-fórica e da gênese das modalidades na economia do percurso gerativo. Além disso, merecem destaque seus estudos a respeito do papel da temporalidade no plano fundamental e, mais recentemente, ao lado de Fontanille, a respeito da organização das valências e dos valores no discurso.

\footnotetext{
${ }^{12}$ Robin, 1977:25.
} 
a) O tempo profundo

Zilberberg categorizou o tempo profundo, compondo um quadrado semiótico ordenado segundo um eixo para a tensividade e um outro para a discretização:

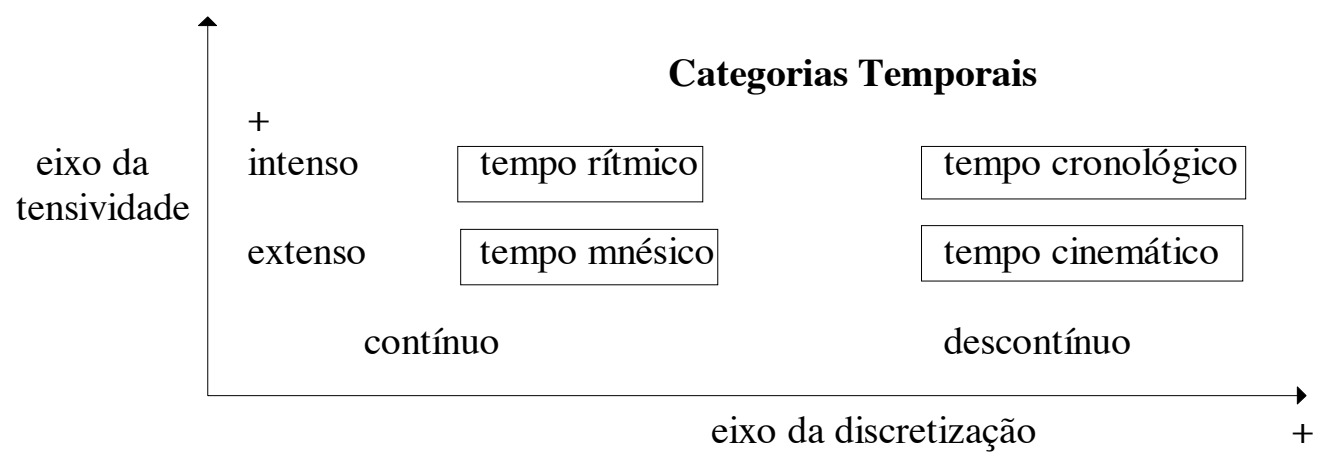

O tempo cronológico, intenso e descontínuo, é responsável pela sucessividade na temporalidade, organizando o tempo em anterioridade e posterioridade e constantemente transformando o presente em passado. Sua ação no nível da intensidade é compensado pela atuação do tempo rítmico, que recupera a continuidade do fluxo temporal ao organizá-lo em sua organização rítmico-silábica, instaurando a previsibilidade que funda a dimensão futura, caracterizada pela espera enquanto expectativa de recursividade das estruturas do devir. O tempo cinemático, extenso e descontínuo, capta as descontinuidades de aceleração crescente ou decrescente do fluxo temporal, ao passo que o tempo mnésico organiza cognitivamente a anterioridade, simultaneidade e posterioridade em passado, presente e futuro, num movimento silábico de compensação em relação à ação do tempo cinemático.

Estudando ainda as interrelações entre as categorias temporais em pares do tipo elemento extenso/elemento intenso, Zilberberg concluiu que a associação do tempo mnésico ao cronológico corresponderia a uma abertura (pode-se deduzir essa e as demais configurações apenas por uma avaliação do gráfico acima), à medida que a diacronização do tempo cronológico expande-se através do tempo mnésico na própria dimensão cognitiva da temporalidade. Já a ação do tempo mnésico sobre o rítmico, ao instaurar a previsibilidade estrutural do discurso, corresponde claramente ao processo de apreensão característico do fechamento cognitivo. Analogamente, a ação do tempo cronológico sobre o cinemático resulta na exacerbação da discretização na intensão da dimensão pontual, mergulhando na dinâmica instantânea do fluxo temporal. A combinação do tempo cinemático com o tempo rítmico, por sua vez, determina a continuidade dinâmica do processo constitucional de silabação, cuja propagação instaura a cursividade na captação temporal do devir.

Estabelecidas assim as correlações entre as categorias temporais, fica patente sua interrelação com os processos de aspectualização incoativa, terminativa, pontualizante e cursiva das modulações do devir cuja discretização (etapa 
imprescindível do processo de significação) resultaria respectivamente nas modalidades do querer, saber, dever e poder, fechando o círculo que relaciona o tempo profundo ao modelo greimasiano de percurso gerativo.

\section{b) Valência/valor}

A contribuição mais recente de Zilberberg, feita em parceria com Fontanille, consiste em um estudo a respeito da ordenação das valências e valores no discurso. No artigo "Valence/valeur"13, os dois semioticistas propõem, em última análise, a organização de ambas as categorias através de sua disposição ao longo de um eixo de natureza extensa e outro de natureza intensa. Assim, as valências passam a ser ordenadas segundo um eixo de profundidade classemática (extenso) e um eixo de profundidade tímica (intenso), ambos orientados da atonia à tonicidade. No artigo citado, os autores comparam duas definições de "cão" (p.18); a primeira, do dicionário Littré, o define como "quadrúpede doméstico, o mais apegado ao homem..."; a segunda, do Robert, como "mamífero doméstico... que cumpre certas funções junto ao homem...". "Quadrúpede" é mais genérico que "mamífero", que, sendo mais específico, é tônico em relação ao outro termo, dispostos os dois ao longo do eixo de profundidade classemática. Timicamente, a primeira definição é nitidamente mais afetiva que a segunda, de caráter mais funcional, sendo assim a primeira tônica em relação à segunda quanto ao eixo de profundidade tímica. Dessa maneira, os autores chegam ao seguinte diagrama:

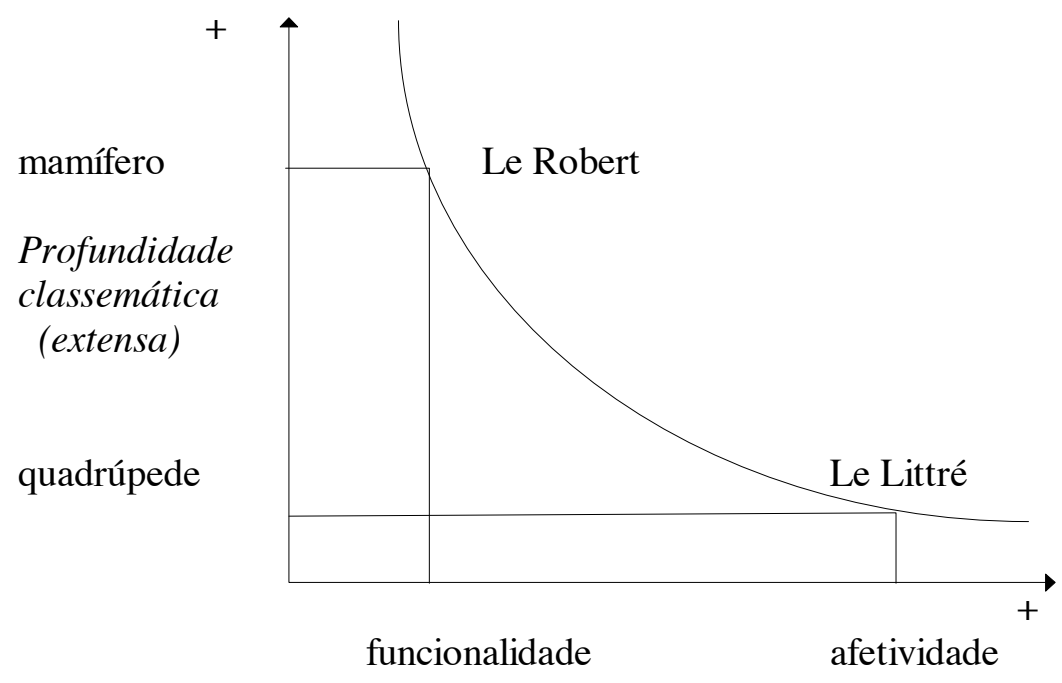

Profundidade tímica

(intensa)

Da mesma forma, ao confrontar a definição do Robert do termo "cão" com aquela que o mesmo dicionário apresenta para "gato", "pequeno mamífero familiar, de pelo macio... que arranha", o eixo extenso passa a corresponder à profundidade funcional, contrastando a tonicidade do cão "doméstico" e útil à atonia do gato meramente "familiar", sem função determinada. O eixo intenso é aqui

\footnotetext{
${ }^{13}$ Zilberberg et Fontanille, 1996.
} 
essencialmente representado pela dimensão tímica sob a forma da chamada profundidade afetiva, onde o gato é apresentado tonicamente pela descrição com ênfase na sensibilização visual e táctil, chegando-se pois ao seguinte diagrama:

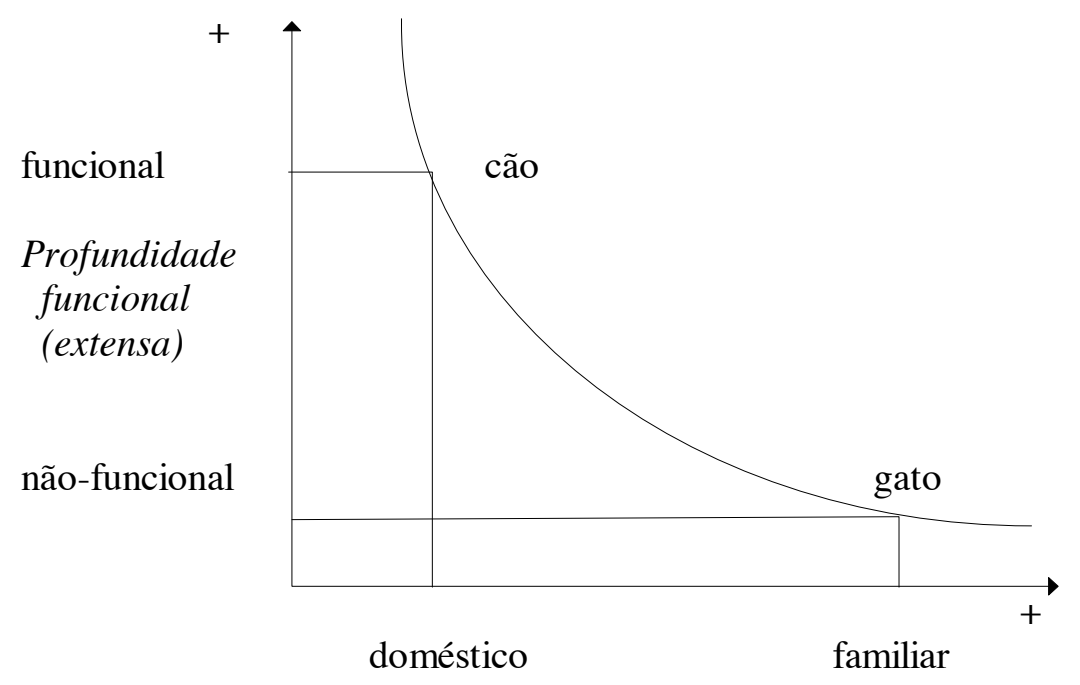

Profundidade afetiva (intensa)

Conclui-se portanto a partir daí por um critério de ordenação das valências ao longo de dois eixos, essencialmente segundo dimensões que se oponham de tal forma a caracterizar uma grandeza como oposta tensivamente à outra, resultando num eixo de ordem "extensa" e outro de ordem "intensa", ambos partindo de uma origem átona e adotando orientação crescente de tonicidade, donde a classificação em cada eixo de termos átonos e tônicos.

Desenvolvendo essa mesma linha de raciocínio a partir da ordenação das valências em conexões de triagem ou de mesclagem, os autores apresentam uma proposta de organização dos valores em última análise também ao longo de um eixo intenso e outro extenso, sendo que no primeiro estariam ordenados os valores do absoluto, relacionados a uma lógica da exclusão (derivada das relações de triagem), enquanto que no segundo estariam os valores do universal, predominando uma lógica da inclusão (resultante das relações de mesclagem). Uma ilustração desse procedimento vem de uma análise de um trecho da obra De la démocracie en amérique, de Alexis de Tocqueville que, comparando a democracia ao absolutismo, considerou que:

... si l'on y rencontre moins d'éclat qu'au sein d'une aristocratie, on y trouvera moins de misères; les jouissances y seront moins extrêmes et le bien-être plus général; les sciences moins grandes et l'ignorance plus rare; les sentiments moins énergiques et les habitudes plus douces; on y remarquera plus de vices et moins de crimes $^{14}$.

Há aí um evidente inventário de valores ordenado segundo os parâmetros concentração (valores representantes do universo absolutista, relacionados

${ }^{14}$ Tocqueville, 1963:28. 
ao eixo intenso) e diluição (valores da democracia, pertencentes ao eixo extenso), resultando no gráfico:

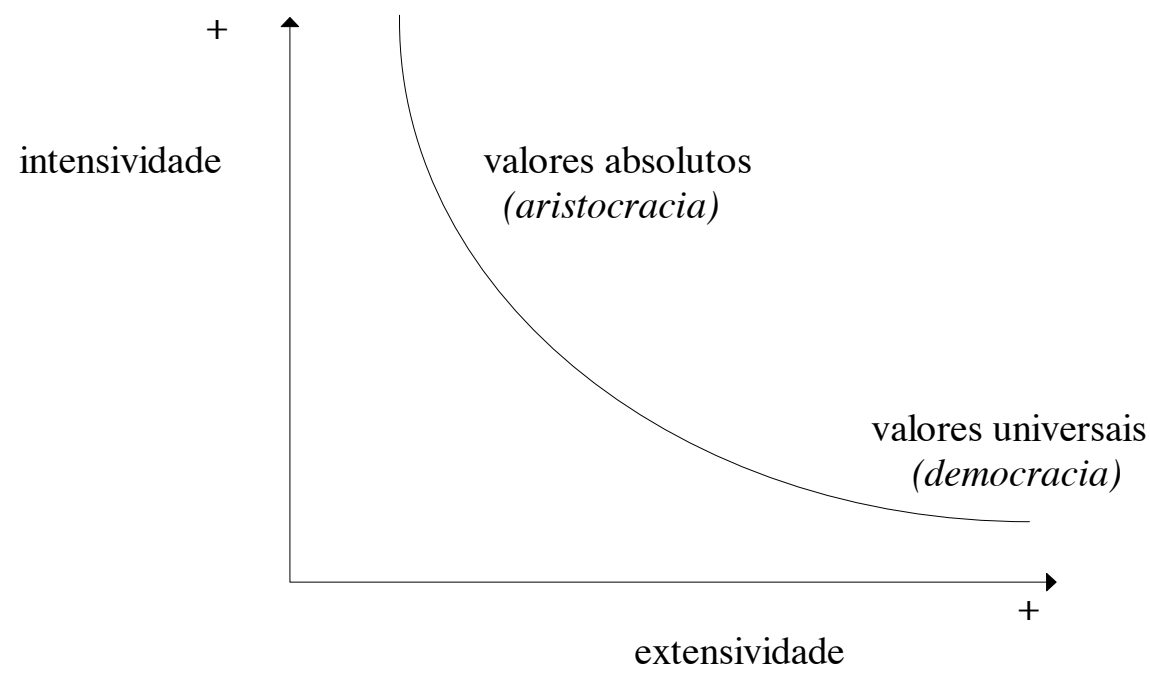

Ordenados os valores, os processos de conexão entre eles (num processo dedutivo análogo àquele efetuado no nível das valências), pela inserção direta na organização do nível narrativo, correspondem em última análise às próprias relações juntivas, cujas implicações nas formas de existência do sujeito resultam na associação entre conjunção e realização; disjunção e virtualização; não conjunção e potencialização; e, finalmente, não disjunção e atualização, sintetizadas no seguinte diagrama:
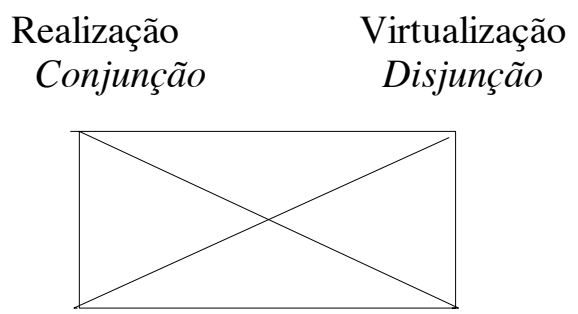
Atualização
Potencialização
Não-disjunção
Não-conjunção

Assim, através do trabalho de Zilberberg e Fontanille, fica melhor detalhado o papel desempenhado no percurso gerativo pela conversão das categorias de nível profundo em valores discursivos, evidenciando-se que aquelas, além de sofrerem simplesmente a conversão, têm ainda por função a regência e ordenação desse processo tanto na eleição do paradigma discursivo que resultará em suas manifestações sob a forma de isotopias, quanto na estruturação de toda a economia do nível narrativo. 


\subsection{A proposta de síntese: a semiótica e os sistemas semi-simbólicos}

Entendem-se por sistemas semi-simbólicos todos os sistemas significantes cuja significação se funda sobre uma correlação entre as categorias que regem seu plano da expressão e aquelas que organizam seu plano do conteúdo. Ao elaborar sua teoria sobre o percurso gerativo, pareceu claro para Greimas que não haveria porque o modelo se limitar à linguagem verbal, já que o sentido não é um privilégio da palavra. Assim sendo, deixou em aberto para aqueles que tivessem competência em linguagens não-verbais a tarefa de aplicar seu modelo a outros sistemas semióticos e de refletir sobre seus resultados, ampliando assim de facto a abrangência da teoria e contribuindo para seu aprimoramento e aprofundamento.

Dentre os trabalhos pioneiros que se aventuraram pelo domínio dos sistemas semi-simbólicos, destaca-se a semiótica visual de Jean-Marie Floch. Inteiramente inserido na linha analítica greimasiana, o autor de Quelques positions pour une sémiotique visuelle ${ }^{15}$ desenvolveu uma metodologia onde basicamente identificam-se oposições estruturais na organização do plano da expressão (freqüentemente segundo a categorização continuidade $x$ descontinuidade) $\mathrm{e}$ estabelecem-se analogias com a estruturação do plano do conteúdo, sobretudo a partir das categorias do nível fundamental. Atento não só à necessidade de expansão do corpus analítico semiótico mas também à viabilidade de sua contribuição enquanto instrumento de reflexão da sociedade a respeito da produção cultural contemporânea, o autor considerou pertinente estender seu campo de interesse à área publicitária, baseando-se no fato de ser a propaganda uma forma de expressão que além de sintetizar meios de diferentes naturezas, veicula ainda de forma direta e indireta toda a dinâmica dos valores sociais. Assim, com seu Sémiotique, marketing et communication $^{16}$, Floch inaugura uma linha de pesquisa da linguagem publicitária (que por sua vez combina, por vezes, elementos pertencentes a diferentes códigos, resultando num complexo visual/musical/verbal), linha essa a partir da qual o raio de ação da semiótica se expande para praticamente todas as mídias, inclusive estabelecendo correlações inusitadas nos campos gastronômico e aromático em trabalhos como 'L'Ève et la cistre: l'emblème aromatique de la cuisine de Michel Bras", publicado em seu mais recente trabalho, Identités visuelles ${ }^{17}$. Vale ressaltar que, além da análise das obras de autores que deixaram para sempre impressos seus nomes nos livros de história da arte, como seu estudo sobre Kandinsky ${ }^{18}$, Floch, ao debruçar-se sobre a criação publicitária, numa postura desmistificadora, jamais deixou de

...exaltar o poder criador dos fotógrafos e desenhistas, até mesmo dos redatores e poetas, sempre livres, em última instância, de enriquecer ou de subverter o material figurativo, ou mesmo, muitas vezes, retórico, que se lhes propõe ou impõe ${ }^{19}$.

Ainda no campo da semiótica visual, há que se destacar ainda dois outros autores: Göran Sonesson, com sua extensa produção onde se destacam obras

\footnotetext{
${ }^{15}$ Floch, 1978.

${ }^{16}$ Floch, 1990.

${ }^{17}$ Floch, 1995.

${ }^{18}$ Floch, 1981.

${ }^{19}$ Floch, 1987.
} 
como Comment le sens vient aux image: un autre discours de la méthode ${ }^{20}$ e Notes sur la macchia de Kandinsky: le problème du langage plastique ${ }^{21}$, e Félix Thürlemann, com trabalhos como seu Paul Klee. Analyse sémiotique de trois peintures $^{22}$

A semiótica do cinema, apresentando uma vasta literatura de linha peirceana que conta até com o privilégio de ter Sergei Eisenstein como um de seus autores fundamentais, apenas a partir da década de 80 vem recebendo maior atenção dos semioticistas de linha francesa. Destacam-se aí o clássico de Christian Metz Film language: a semiotics of the cinema ${ }^{23}$, leitura obrigatória nos principais cursos de cinema do mundo inteiro, e How to read a film ${ }^{24}$, de James Monaco, que abriu uma perspectiva passível de expansão para uma semiótica da TV, hoje fundada nas obras Television culture ${ }^{25}$, de John Fiske, e Media analysis techniques ${ }^{26}$, de Arthur Asa Berger. Paralelamente, desenvolveu-se também uma semiótica da fotografia, onde se destaca o trabalho de Victor Burgin, Thinking photography ${ }^{27}$.

Os fundamentos de uma semiótica musical tem sido lançados principalmente através das pesquisas de dois autores: Eero Tarasti e Luiz Tatit. O primeiro, notadamente em seu mais recente trabalho, Sémiotique musicale ${ }^{28}$, utiliza com bastante liberdade o modelo greimasiano de percurso gerativo, adotando ainda freqüentemente conceitos, terminologia e métodos analíticos procedentes da semiótica peirceana (verificando-se nessa confluência uma clara influência do pensamento de Thomas Sebeok ${ }^{29}$ a respeito da semiótica das artes), procurando assim conciliar diferentes estratégias de abordagem textual para atingir dessa forma uma leitura objetiva mas não limitadora (e, sobretudo, não dogmática) do texto poético. Em seu esforço teórico heterodoxo, Tarasti se vale ainda de conceitos musicológicos desenvolvidos por eminentes pesquisadores como Ernst Kurth ${ }^{30}$ e Boris Asafiev ${ }^{31}$, além de, no campo das modalidades, adotar o modelo lógico de Wright $^{32}$ além do equacionamento modal proposto por Greimas. Interessante notar que, apesar de seu ecletismo, o autor da Sémiotique musicale compartilha com Eugène Narmour ${ }^{33}$ severas críticas ao modelo estruturalista de análise musical desenvolvido por Heinrich Schenker, que, apesar de seus méritos metodológicos e de seu papel revolucionário no contexto da história da teoria musical, é contestado com alguma justiça à medida que, para os dois autores, parte sempre de um axioma predeterminado (em última análise, a própria Ursatz), tendendo a excluir para efeitos de análise toda e qualquer estrutura incompatível (geralmente classificando-a comodamente como "prolongation" ou

\footnotetext{
${ }^{20}$ Sonesson, 1989.

${ }^{21}$ Sonesson, 1987.

22 Thürlemann, 1982.

${ }^{23}$ Metz, 1974.

${ }^{24}$ Monaco, 1981.

${ }^{25}$ Fiske, 1987.

${ }^{26}$ Berger, 1982.

${ }^{27}$ Burgin, 1982.

${ }^{28}$ Tarasti, 1996.

${ }^{29}$ Sebeok, Thomas. Semiotics in the United States. Bloomington: Indiana University Press, 1991.

${ }^{30}$ Kurth, Ernst. Musikpsychologie. Hildesheim: Georg Olms, 1947 [1992].

${ }^{31}$ [Asafiev] Assafjew-Glebow, B. W. (n.d.). Tschaikowskys "Eugen Onegin": versuch einer analyses des stils und der musikalischen dramaturgie. Potsdam: Athenaion.

${ }^{32}$ Wright, Georg Henrik von. Norm and action: a logical enquiry. London: Routledge and Kegan Paul, 1963.

${ }^{33}$ Narmour, Éugène. Beyond schenkerism: the need for alternatives in music analysis. Chicago:

University of Chicago Press, 1977.
} 
"transition") com o modelo pressuposto (Tarasti, 1996:17). Entretanto, é inegável o mérito da obra de Tarasti tanto no que tange a sua tentativa de sintetizar diferentes linhas do pensamento semiótico e musicológico num método bem estruturado de análise do discurso musical quanto ao relativo ineditismo de uma aplicação, ainda que não ortodoxa (e pouco atualizado no que concerne aos mais recentes avanços da teoria, realizados pelos esforços de Fontanille, Kristeva, Zilberberg, Tatit e Floch, avanços esses em parte já comentados neste trabalho), do modelo greimasiano no universo musical, abordando com bastante eficiência o repertório erudito ocidental.

O segundo autor a desenvolver um trabalho na área da semiótica musical é Luiz Tatit. Focalizando sua pesquisa especificamente na análise da canção popular brasileira, a limitação da abrangência teve por contrapartida um grande aprofundamento teórico a partir do qual Tatit, valendo-se das mais recentes conquistas teóricas da semiótica pós-greimasiana, desenvolve tendo por referência principalmente as teses de Zilberberg a respeito do nível profundo um trabalho pioneiro onde a canção popular, num ponto de vista absolutamente coerente com a historicidade do processo de criação do cancionista (quase sempre carente de qualquer instrução musical formal), é analisada sob uma ótica entoativa, e não melódica. Com essa postura, o autor da Semiótica da canção ${ }^{34}$ justifica sua preocupação lingüística não só com a componente verbal (a letra) desse texto sincrético, mas com a estrutura silábica de sua enunciação, estudando a componente melódica enquanto acentos e modulações (segundo a ótica hjelmsleviana) da variante entoativa da fala em que consiste, em última análise, o canto (dentro dos limites da forma de expressão eleita pelo autor). Ao contrário de Tarasti, Tatit trafega confortavelmente dentro da metodologia greimasiana, atingindo através de um notável domínio do complexo teórico que compõe a atual semiótica francesa uma visão do percurso gerativo na canção capaz de generalizações como a detecção dos traços estilísticos que separam as canções "temáticas" das "passionais", verificando nelas respectivamente a predominância de valores extensos e intensos, antecipando assim de certa forma as mais recentes publicações de Zilberberg e Fontanille a respeito das relações entre valores e estados juntivos, onde esses autores se aprofundam na associação entre valores extensos e estados conjuntivos, valores intensos e estados disjuntivos (Zilberberg e Fontanille, 1996:62-69). Excluindo deliberadamente de suas análises algumas ferramentas da teoria musical capazes de auxiliá-lo na investigação do sentido na canção, o semioticista brasileiro terminou por explorar ao máximo os recursos da teoria semiótica de forma a compensar a ausência, por exemplo, de uma exploração do papel da dimensão harmônica no complexo letra-música. Resultou dessa estratégia um robustecimento do modelo de percurso gerativo, notadamente quanto ao nível profundo, abrindo um importante precedente no estudo dos sistemas semi-simbólicos e lançando definitivamente o embasamento necessário para uma abordagem semiótica, e não simplesmente musicológica, do texto musical em outros domínios que não o da canção brasileira.

\section{Do percurso gerativo do sentido}

\footnotetext{
${ }^{34}$ Tatit, 1994.
} 


\subsection{A silabação enquanto fundamentação de uma leitura semiótica do discurso musical}

Um dos aspectos mais surpreendentes da análise do plano da expressão de um texto musical qualquer é aquilo que se pode chamar de seu geometrismo. Um texto musical é constituído em última análise por uma célula rítmico-melódica que se repete incessantemente, reapresentando-se porém invertida, retrogradada, transladada, expandida ou contraída, gerando assim uma estrutura de abertura-fechamento indissociável do próprio conceito de silabação. A articulação e oposição de dois únicos intervalos costuma dar conta de toda a estrutura de composições musicais extremamente complexas, num grau de coerência espantoso para quem conhece o peso da intuição no processo de criação, apontando como única explicação plausível responsabilizar um senso de equilíbrio infinitas vezes mais rápido e preciso que a razão (e, até certo ponto, independente dela) pela consistência lógica da construção do texto.

Se esse tipo de configuração estrutural de alta coerência, marcado por operações à primeira vista bastante abstratas como a inversão e a retrogradação, é até certo ponto esperado de compositores que tinham uma notória preocupação com a forma, como por exemplo os chamados três B's da música, Bach, Beethoven e Brahms, o mesmo tipo de coesão e concisão, encontrado em peças absolutamente despretensiosas de autores populares considerados até certo ponto "ingênuos" (ao menos pelos músicos eruditos) passa a apontar as operações descritas acima não mais especificamente como o fruto do engenho dos grandes mestres, mas como uma forma de articulação intrínseca à própria linguagem musical. Apenas para ilustrar essa organização do plano da expressão, tomemos como exemplo a canção $E$ doce morrer no mar, de Dorival Caymmi, atentando para o geometrismo de sua estruturação melódica e em seguida identificando o processo de silabação nela implícito.

Por se tratar de uma canção cuja estrutura melódica se repete associada a estrofes diferentes, bastar-nos-á considerar a primeira seção da composição:

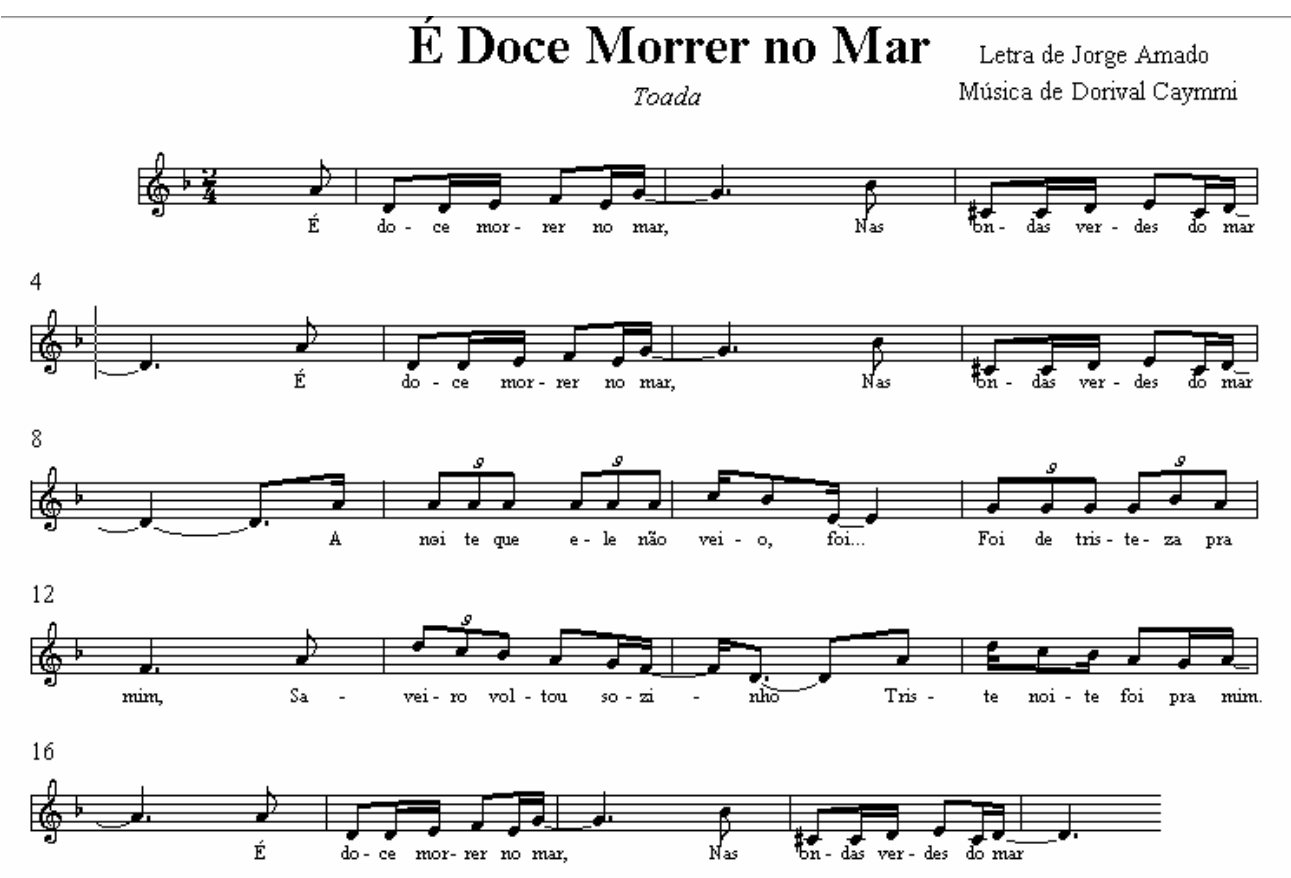


Tomemos o tema ${ }^{35}$ da música:

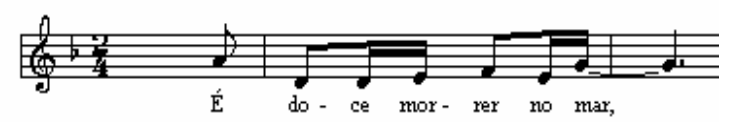

Trata-se evidentemente da articulação de dois intervalos: a 5.a justa descendente;

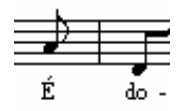

aqui em sua forma sintética; e a 3.a menor ascendente, apresentada uma primeira vez de forma analítica;

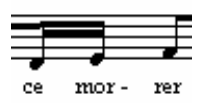

sintética:

e uma segunda vez, transposta um tom acima e exposta de forma

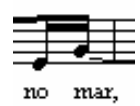

De modo a recuperar desde já a perspectiva semiótica de nossa análise, consideremos a hipótese de Hjelmslev de correspondência entre categorias do plano da manifestação e categorias do plano do conteúdo. Ao afirmar que o plano da expressão se organiza pela articulação de dois únicos intervalos, isso implica a existência de um binômio análogo no plano do conteúdo, binômio esse que deverá corresponder a duas categorias contrárias. Por se tratar de um campo semântico nãoverbal, convém evitar qualquer tipo de figuratividade, excluindo-se assim os clássicos pares natureza/cultura e vida/morte, buscando outrossim categorias mais abstratas, como continuidade/descontinuidade e intensividade/extensividade. Dentre essas últimas opções, por ser mais condizente com o meio de expressão, pela gama de efeitos de sentido de natureza estética e emotiva que desencadeia, e, last but not least, como uma herança do pensamento musical schenkeriano, elegeremos o par intensividade/extensividade. Assim sendo, um dos dois intervalos corresponderá à discursivização do elemento intenso, e o outro, ao elemento extenso. No caso do trecho citado, tendo a 3.a menor sido exposta duas vezes, a primeira de maneira analítica, a segunda, sintética, enquanto a 5.a é exposta apenas sinteticamente, estabelece-se a relação:

$$
\begin{aligned}
& \text { 5.a justa } \longrightarrow \text { elemento intenso } \\
& \text { 3.a menor } \longrightarrow \text { elemento extenso }
\end{aligned}
$$

\footnotetext{
${ }^{35} \mathrm{O}$ termo tema aqui utilizado, aparentemente referente a seu homônimo em teoria musical, apresentase aqui também em sua acepção semiótica. Conforme será explicado mais adiante, o conceito de tema musical é inteiramente compatível com a tematização discursiva, desde que se a assuma enquanto categoria abstrata do campo semântico musical, categoria essa não necessariamente lexicalizável.
} 
Conforme vimos na análise dos trabalhos mais recentes de Zilberberg e Fontanille, a economia desse sistema semiótico será regida também por um eixo de valores intensos e um de valores extensos. Se observarmos com maior profundidade, veremos que o intervalo de 3.a, portador dos valores extensos do sistema, apresenta-se tensionado em sua segunda apresentação, de caráter sintético, harmonicamente e melodicamente mais tensa que sua aparição imediatamente anterior. Constata-se assim um fluxo de valores da seguinte forma:

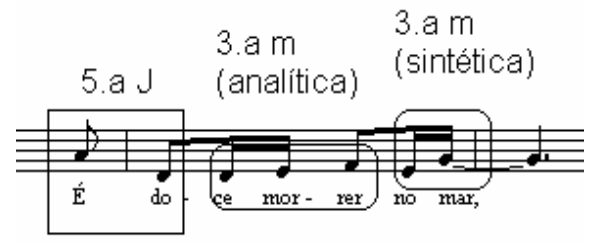

$$
\begin{aligned}
& \text { elemento extensão } \\
& \text { intenso }
\end{aligned} \stackrel{\text { elemento intensão }}{\longrightarrow}
$$

Fica assim patente a alteração de estado juntivo entre a primeira 3.a, em conjunção com valores extensos, e a segunda, já situada em um eixo de intensão. Ao mesmo tempo, a partir daí já começam a se configurar a ciclicidade típica da silabação, a economia do sistema com seus desdobramentos nos três níveis do plano do conteúdo e a conseqüente semiotização a partir da qual o texto musical passa a ser alvo de nosso interesse neste trabalho. Por motivos de clareza de exposição, entretanto, voltemos a nos limitar o tanto quanto possível à organização do plano da expressão, ao passo que continuaremos apresentando os fundamentos que justificam uma leitura semiótica do texto musical.

Analisada a construção da estrutura melódica do tema, vejamos agora a segunda frase da composição:

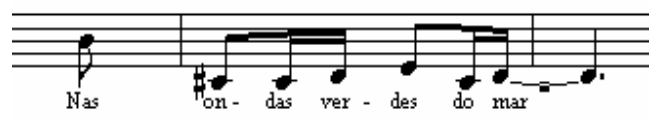

A primeira parte da frase é uma transposição harmônica do tema:

Harmonia em Dm

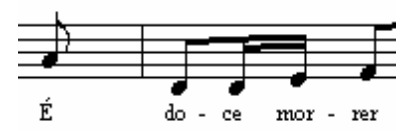

Harmonia em A9>

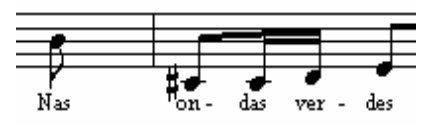

Além disso, o intervalo:

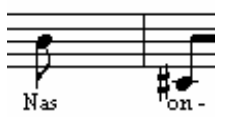


constitui uma 7.a diminuta, resultante da sobreposição de três intervalos de 3.a m. Assim, no lugar da 5.a J, um elemento intenso, temos um intervalo resultante da expansão da 3.a m (trata-se mais propriamente da expansão de um para três intervalos de $3 . \mathrm{a} \mathrm{m}$, que sofrem uma aceleração, intensificando-se e fundindo-se no novo intervalo), confirmando sua aquisição de valor intenso. Comparemos agora atentamente as terminações da primeira e da segunda frase:

1.a Frase

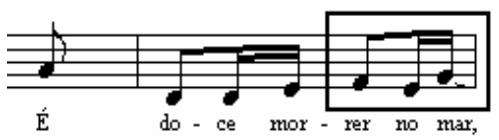

2.a Frase

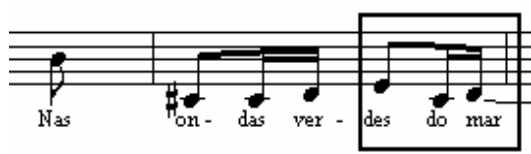

Tomando a terminação da 1.a Frase,

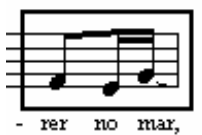

verificamos que seu retrógrado (a célula de trás para frente) é:

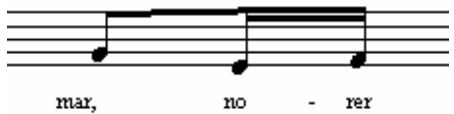

que, por sua vez, transposto uma 3.a menor abaixo, resulta absolutamente idêntico à terminação da 2.a frase:

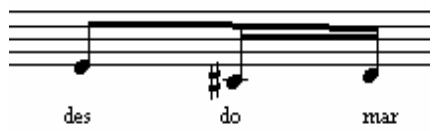

Portanto, a primeira metade da 2.a frase deriva da 1.a por expansão e transposição, e a segunda, por retrogradação. Quanto ao plano do conteúdo dessa terminação, assumindo novamente a correlação proposta por Hjelmslev, concluímos que a retrogradação de uma intensão corresponde naturalmente a uma extensão, complementando assim coerentemente mais um fragmento da estrutura silábica:

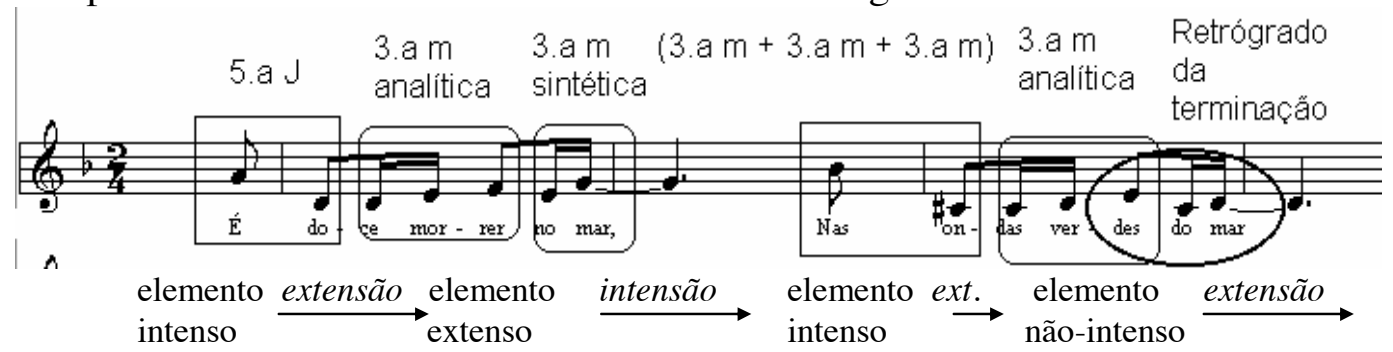

A partir do plano do conteúdo, verificamos que transformação da Frase1 na Frase 2 foi regida por uma alteração de estado juntivo, onde a 3.a m, inicialmente portadora de valores extensos, passou à conjunção com os valores intensos do sistema. A pulsação intensão/extensão evidencia mais uma vez o processo de silabação, corroborando a proposta de partir desse processo para justificar uma leitura semiótica da composição. 
Dando continuidade à nossa análise do plano da expressão, visando comprovar o geometrismo de sua organização nos termos propostos no início deste tópico, verifiquemos agora como se constitui a partir dos elementos fundadores (os intervalos de 5.a $\mathrm{J}$ e $3 . \mathrm{a} \mathrm{m}$ no contexto funcional em que se apresentam na música) a 3.a Frase:

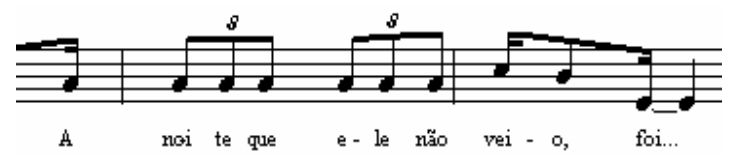

Para compreender a composição dessa frase, atentemos novamente para o tema:

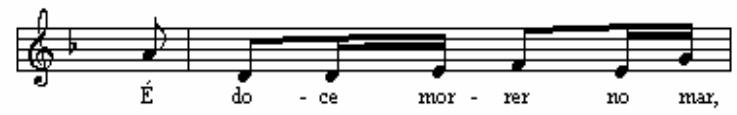

Consideremos mais uma vez sua terminação:

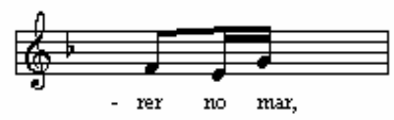

Conforme visto anteriormente, o seu retrógrado

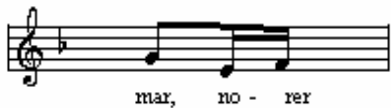

gera por transposição a terminação da 2.a Frase:

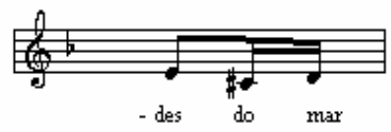

Seja agora a inversão da célula supracitada. Obtemos por esse processo a seguinte figura melódica:

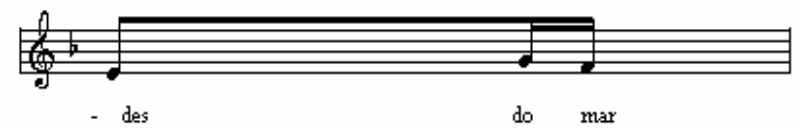

Trata-se de uma transposição exata do princípio da 3.a Frase, desprezando-se a reiteração conseqüente da letra:

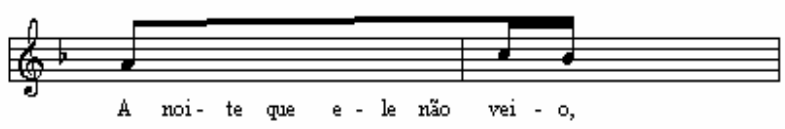

Conseqüentemente, está justificada geometricamente a gênese do fragmento melódico correspondente à primeira metade dessa frase como inversão (e transposição) da terminação da frase anterior. Vejamos agora sua terminação:

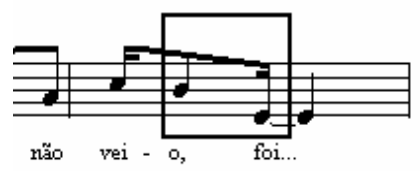

Trata-se simplesmente de um intervalo descendente de 5.a diminuta, constituindo uma contração do intervalo fundador de 5.a J. Assim sendo, está justificada morfologicamente a estrutura da 3.a Frase. Verifiquemos as implicações imediatas de tal constituição no plano do conteúdo. 


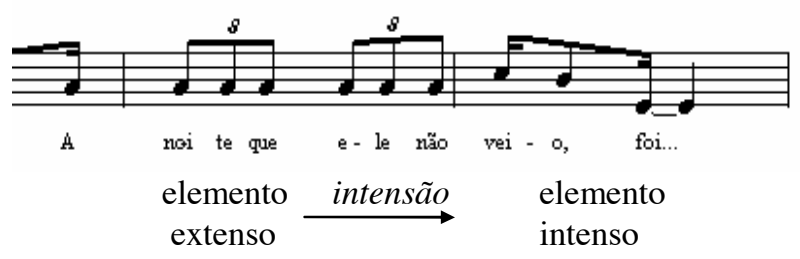

Após o processo de extensão no final da frase anterior, o intervalo de 3.a recuperou seu estatuto de portador dos valores extensos, de maneira aspectualmente mais acentuada que no princípio da composição. $\mathrm{O}$ processo de intensão marcado pelo tensionamento harmônico culmina com o elemento intenso, novamente representado por um intervalo de 5.a, tensionado por contração resultando no intervalo de 5.a diminuta (também chamado trítono).

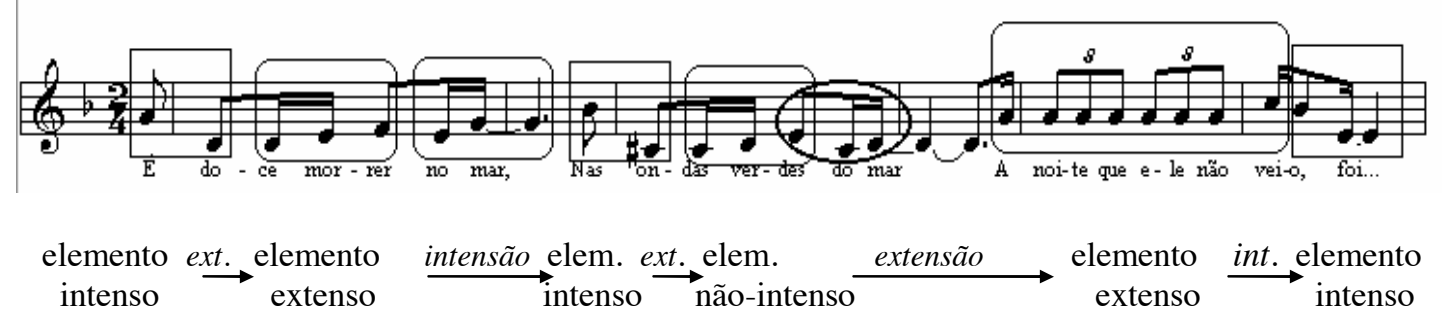

Vamos pois à análise da 4.a Frase:

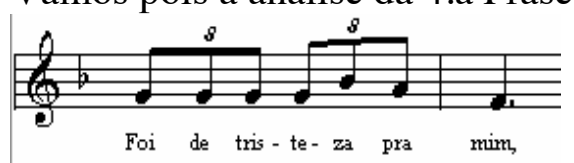

Para compreender sua estrutura, evidentemente análoga à da frase anterior, consideremos também a 1.a Frase:

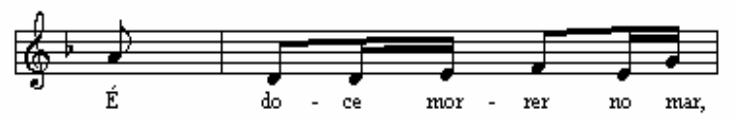

Seu retrógrado é:

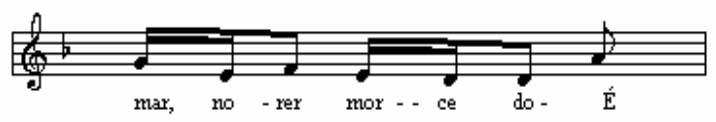

Assim sendo, o inverso do retrógrado da 1.a Frase é:

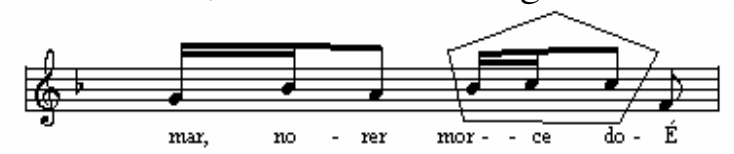

Omitindo a parte assinalada pelo polígono, temos por resultado exato a estrutura da 4.a Frase: 

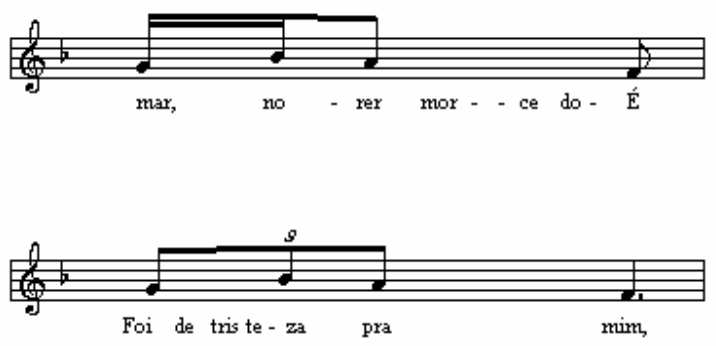

Concluímos daí, portanto, que a 4.a Frase deriva geometricamente do inverso do retrógrado da 1.a Frase. Conseqüentemente, quanto ao plano do conteúdo, há uma inversão do quadro tensivo da 1.a Frase:

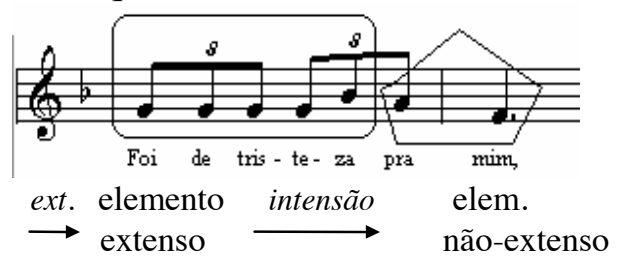

Seja agora a 5.a Frase:

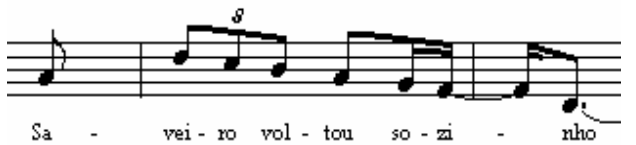

Analisemos a formação de sua primeira metade:

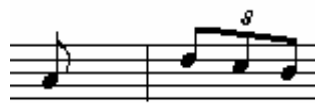

Para isso, recorreremos à 1.a Frase:

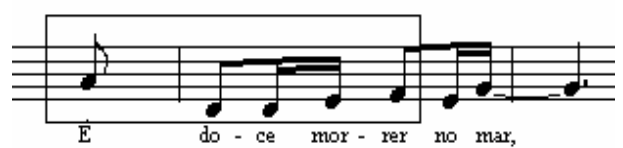

Através da inversão tonal do trecho assinalado, chegamos a:

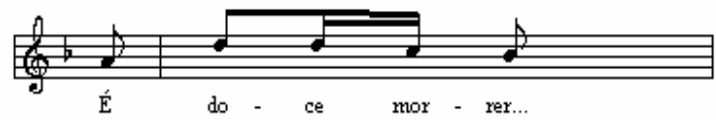

Ao desprezarmos a reiteração, temos:

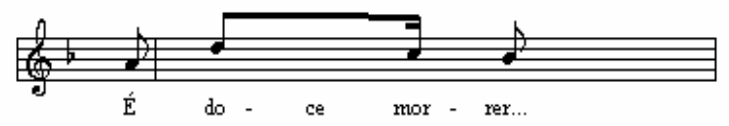

chegando assim a uma estrutura idêntica à do trecho indicado:
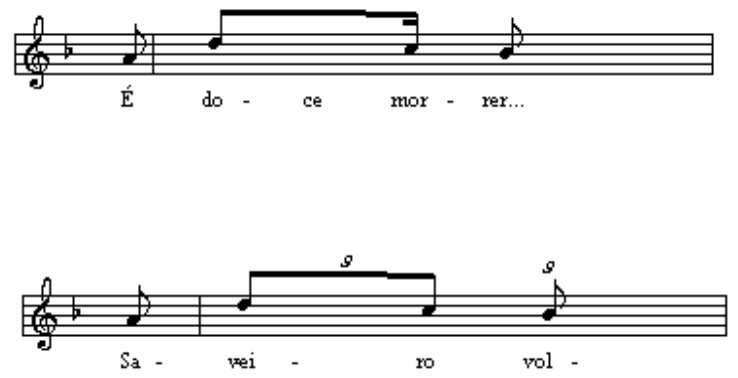

Vamos agora ao restante da 5.a Frase, assinalado na figura abaixo: 


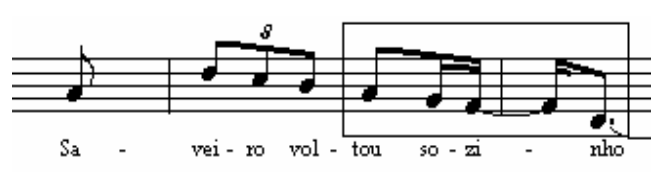

Trata-se simplesmente de um intervalo de 5.a justa descendente exposto analiticamente. No nível do conteúdo, isso nos remete a uma mudança no estado juntivo do intervalo de 5.a, que, inicialmente em conjunção com os valores intensos, agora apresenta-se em conjunção com os valores extensos do sistema. Assim, o quadro tensivo da 5.a Frase pode ser diagramado da seguinte maneira:

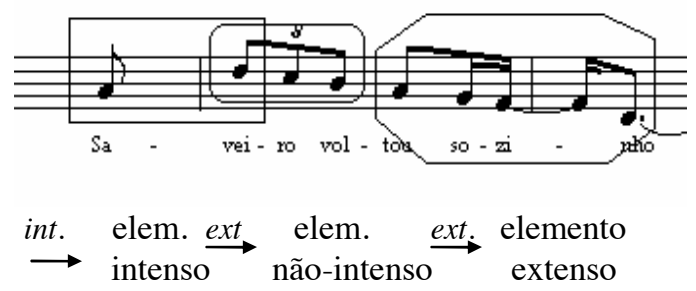

Finalmente, tomemos a 6.a e última frase:

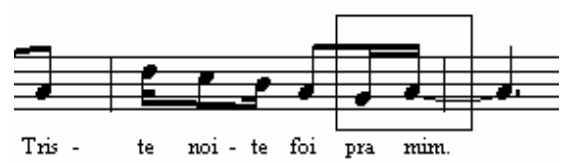

Apenas a terminação (área marcada) difere da frase anterior. Assim sendo, vejamos como se origina esse termo, através de uma visão mais genérica da configuração do plano da expressão.

A semelhança entre a apresentação das frases 1 e 2 , diferindo essencialmente apenas por suas terminações, e o fato da terminação de 2 ser derivada do retrógrado da terminação de 1 faz com a segunda frase seja ouvida como resposta da primeira (trata-se já, de certa forma, de um efeito de sentido).

Comparemos as duas terminações (áreas assinaladas):

Frase 1

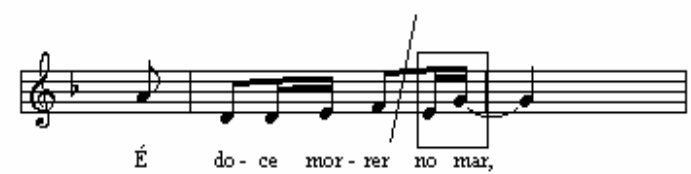

Frase 2

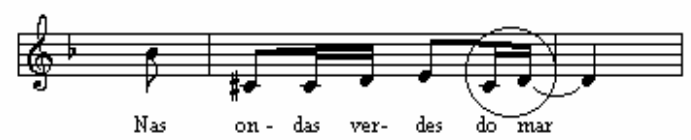

Existe uma analogia semelhante entre as frases 5 e 6 :

Frase 5
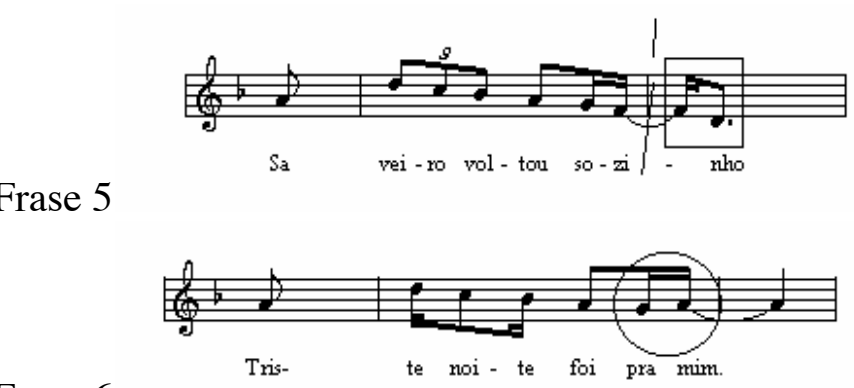

Frase 6 
Assim, verificamos que as frases 2 e 6 , ambas respostas ${ }^{36}$ de seus antecedentes imediatos, têm por terminação um intervalo de 2.a ascendente. Podemos daí inferir que o intervalo citado, dentro da sintaxe do texto analisado, apresenta função gramatical terminativa. Portanto, estruturalmente, consideraremos que a terminação da Frase 6 se origina diretamente da terminação da Frase 2. A terminatividade, no plano do conteúdo, é marcada, segundo Greimas, por uma aspectualização de fechamento, relacionando-se dessa forma com uma intensão da tensividade, resultando o quadro tensivo no diagrama:

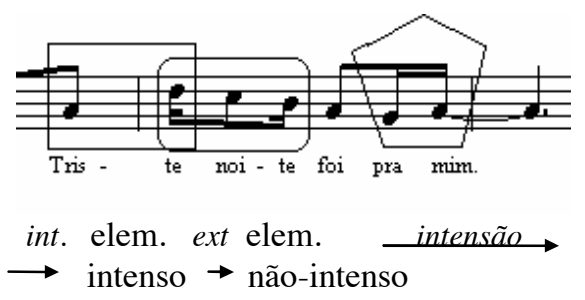

A intensão do trecho final é inclusive marcada também pelo tensionamento harmônico com um acorde de dominante, confirmando a estrutura tensiva da melodia.

Inventariados assim os procedimentos de estruturação melódica da composição, procuremos agora (baseando-nos em parte em procedimentos comuns na análise schenkeriana) atingir uma visão panorâmica de suas principais mudanças de estado a partir de uma certa simplificação que não chegue a distorcer a configuração geral da peça. Para isso, nomearemos as microestruturas fundadoras e descreveremos os procedimentos pelos quais essas se transformam, gerando a estrutura discursiva. Seja portanto o tema. Nele, identificaremos como a a microestrutura derivada do intervalo de 5.a justa, e como $\underline{b}$ aquela derivada do intervalo de $3 . a$ menor. Podemos esquematizar da seguinte forma a lógica que rege as mudanças de estado detectáveis no plano da expressão:

Frase 1: Apresentação do Tema (a, b)

Frase 2: Expansão de $\underline{a}$, retrogradação de $\underline{b}$ (a', -b)

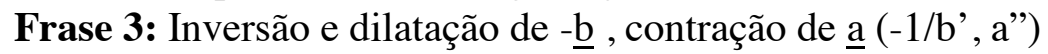

Frase 4: Inversão e dilatação de $-\underline{b}$, inversão e contração de $-\underline{a}\left(-1 / b,-1 / a^{2}\right)$

Frase 5: Inversão de $\underline{\mathrm{a}}$, expansão de $\underline{\mathrm{a}}$ (1/a, a"')

Frase 6: Inversão de $\underline{a}$, retrogradação de $\underline{b}$ (1/a, -b")

Para tornar o processo menos abstrato, valhamo-nos de um diagrama onde os processos serão ilustrados utilizando-se o signo $\bigcirc$ para representar a e para representar $\underline{b}$, sofrendo os dois signos os processos de retrogradação e inversão descritos acima.

\footnotetext{
${ }^{36}$ Vale lembrar que os termos pergunta e resposta, da maneira como estão utilizados nesse trecho, estão em pleno acordo com a conotação a eles conferida pela teoria musical tradicional.
} 


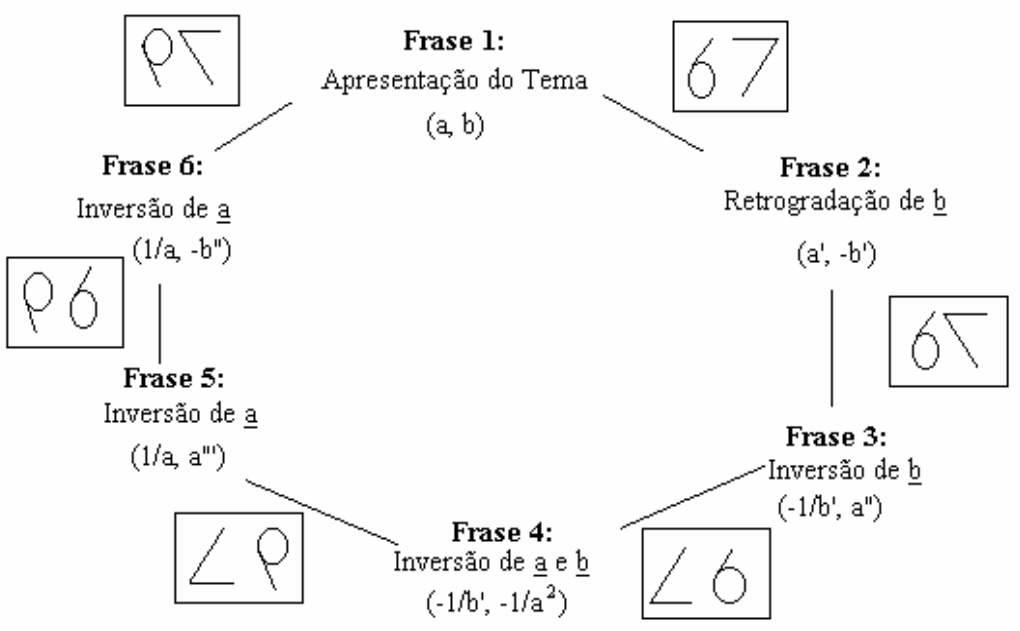

Por esse diagrama, verificamos que pode-se organizar a narratividade do texto em duas transformações essenciais, resultando em três grandes seções. Na primeira seção, composta pelas Frases 1 e 2, temos basicamente o tema propriamente dito, $(a, b)$; a segunda seção (Frases 3 e 4) é regida pela inversão (do retrógrado) de $\underline{b}$ $(-1 / b, x)$; a terceira e última, (Frases 5 e 6$)$, pela inversão de a $(1 / a, x)$; finalmente, fecha-se o ciclo voltando-se para o Tema-Refrão $(a, b)$. Ora, temos aí uma estrutura regida basicamente por inversões:

Seção 1 inversão (de $\underline{b}$ ) Seção 2 inversão (de $\underline{a}$ ) Seção 3 inversão (de lla e de $\underline{\text { l/b }}$ ) Seção 1 $(\mathrm{a}, \mathrm{b}) \longrightarrow(-1 / \mathrm{b} ; \mathbf{x}) \longrightarrow(\mathbf{1} / \mathbf{a}, \mathbf{x}) \longrightarrow$

O próprio encerramento do ciclo, com a passagem da Seção 3 à 1, dá-se analogamente por inversão, pois já tendo-se invertido $\underline{b}$ em 2 e a em 3 , o processo se completa com a inversão dos inversos, como mostra o diagrama, retornando-se assim ao par $(a, b)$ inicial.

Quanto ao plano do conteúdo, pode-se observar de maneira geral a pulsação tensiva resultando num processo de silabação e a alteração de estado juntivo dos valores do sistema (por sua vez organizados por extensividade e intensividade) permeando toda transformação de estado:
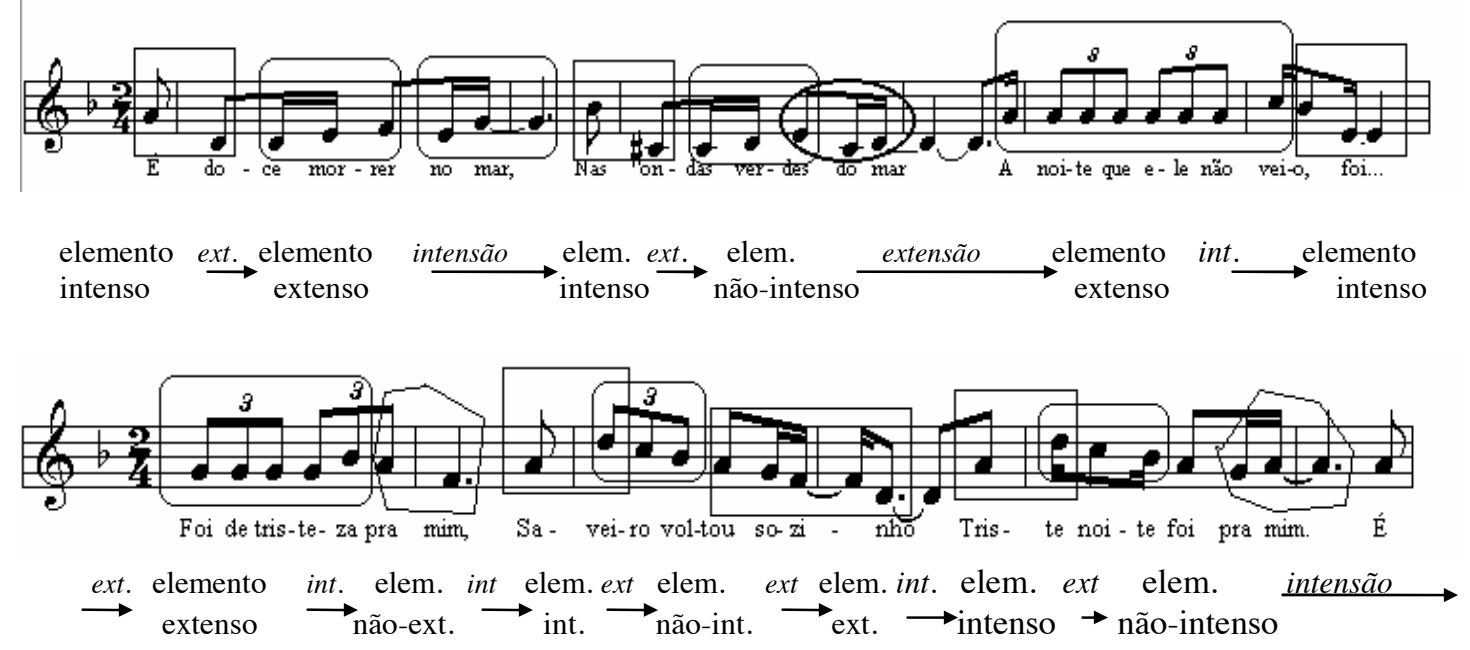
Analisando as alterações juntivas, na Seção 1 assistimos o elemento $\underline{b}$ ( $\underline{b}$ e $\underline{a}$ assumindo aqui o papel de actantes discursivos e de sujeitos das transformações de estado) cumprir o percurso desde a conjunção com os valores extensos até a conjunção com os valores intensos (de 1 a 2 ), terminando a seção conjunto com os valores não-intensos; na Seção 2, $\underline{b}$ recupera seu valor extenso, mas agora aspectualizado pela própria pulsação gerada pelo ciclo sofrido, resultando num $\underline{\mathrm{b}}$ exageradamente extenso e num a exageradamente intenso; finalmente, a característica da Seção 3 é a entrar em conjunção com os valores extensos do sistema.

Assim, o exemplo citado serve para ilustrar dois aspectos de vital importância para este trabalho, quais sejam:

a) o geometrismo que ordena e estrutura o plano da expressão de um texto musical qualquer;

b) a atuação do princípio hjelmsleviano de homologia entre os planos de expressão e conteúdo fundamentando através do processo de silabação uma leitura semiótica do texto musical, leitura essa que mesmo numa análise relativamente superficial nos possibilitou vislumbrar alguns elementos da organização discursiva, narrativa e profunda atuando na economia do percurso gerativo de sentido do texto musical abordado.

Algumas considerações finais agora sobre a escolha do exemplo analisado. Como se poderá observar no decorrer deste trabalho, o geometrismo constatado é ao que tudo indica uma propriedade fundamental sobre a qual se constituem e articulam os elementos da linguagem musical gerando os textos musicais. Embora exista uma pluralidade imensa de idiomas musicais, tal propriedade parece tão intrínseca a essa modalidade de linguagem quanto a existência de alguma forma de gramática o é para qualquer língua existente, sendo esse tipo de organização e algumas de suas implicações semânticas o que há de mais "universal" na manifestação musical. Entretanto, limitaremos o escopo analítico dessa obra a um repertório ocidental tonal, não por achar que as conclusões aqui expostas se circunscrevam a esse território, mas apenas para garantir uma certa familiaridade do leitor com textos que ilustrem as principais questões a serem aqui discutidas.

O texto de Caymmi foi escolhido principalmente por não ser obra de um formalista atento às relações de simetria de suas composições, como certamente seria o caso se fosse escolhida aqui qualquer peça do repertório erudito. Precursor da bossa nova com sua Marina e consagrado compositor regionalista, Caymmi, um dos cancionistas mais importantes da música popular brasileira do século XX, não recebeu instrução musical formal, como aliás a quase totalidade de seus colegas brasileiros, como nos aponta Tatit em seu $O$ cancionista ${ }^{37}$. Como personalidade, folclorizou-se sua notória aversão a prazos, sua simplicidade e despojamento, seu temperamento simples e meditativo, atribuindo-lhe o imaginário popular o rótulo de "preguiçoso 38 ". Para quem está familiarizado com esse estereótipo, é simplesmente inviável conceber Caymmi trabalhando conscientemente com inversões e retrogradações de fragmentos temáticos, compondo uma estrutura binária onde uma Seção I se transforma numa

\footnotetext{
${ }^{37}$ Tatit, 1996:106

${ }^{38}$ Sobre a "preguiça" de Caymmi, ver Jorge Amado: "Uma arte criada ao sabor do tempo baiano". In:História da música popular brasileira. São Paulo, Abril, 1982.
} 
Seção II pela articulação da inversão de sua primeira metade, numa Seção III pela inversão de sua segunda metade para, num arremate final e segundo uma profunda coerência estrutural, retornar à Seção I por uma nova inversão, já que o inverso de uma inversão coincide com a própria estrutura original. Assim, tendo um tal nível de coerência sido encontrado em todas as peças analisadas (naturalmente com uma certa variação em grau), trata-se evidentemente de uma estruturação intrínseca à própria linguagem musical, uma gramática gerativa cujos fundamentos conceituais podem ser encontrados na própria física acústica tão cara aos sumérios e gregos, a Pitágoras, Aristóxenus e Rameau ${ }^{39}$. Através do geometrismo da linguagem musical, torna-se patente sua ritmicidade, e é precisamente esse aspecto rítmico que, reiterando, nos remete fortemente à silabação enquanto instância fundadora de uma plano do conteúdo para a linguagem musical. Ficam dessa maneira expostos os fundamentos semióticos a partir dos quais abordaremos o discurso musical e investigaremos seu percurso gerativo de sentido,

a) estudando a compatibilidade do modelo greimasiano com as características essenciais da linguagem musical;

b) fazendo um inventário descrevendo e justificando as eventuais adaptações necessárias à aplicação da teoria ao corpus musical;

c) comparando os efeitos de sentido constatados mediante análise com aqueles atribuídos a cada texto em particular pela tradição musical ou pelo próprio autor (caso da Sinfonia n.o 4 de Tchaikovski).

\subsection{Do nível profundo}

No que tange à sua compatibilidade com o discurso musical, o modelo de percurso gerativo de sentido proposto por Greimas, com sua subdivisão do plano do conteúdo em três patamares de significação, é especialmente feliz no que concerne a suas considerações a respeito do chamado nível profundo ou nível das estruturas fundamentais. Caracterizando-se por operar com as categorias mais simples e abstratas da organização de sentido de um texto, o modelo greimasiano de nível profundo pode ser aplicado ipsis litteris a uma obra musical sem haver a necessidade de maiores adaptações, e oferecendo ainda como atrativo uma maior visibilidade em relação à linguagem verbal de seu papel no processo de geração de sentido. Devido entretanto exatamente a essa diferença de nitidez que nesse caso privilegia o discurso musical (em franca oposição àquilo que ocorre, por exemplo, ao tentarmos adaptar o atual modelo de nível discursivo à linguagem musical) cabem aqui algumas considerações detalhadas a respeito do papel do nível profundo na economia do

\footnotetext{
${ }^{39}$ Os conceitos de inversão e retrogradação, à primeira vista abstratos, são bastante concretos na acústica. E.g.: um som é produzido ao se fazer uma fração de uma corda vibrar a fração complementar, que não vibra, se estimulada, produz o intervalo invertido.
} 
percurso gerativo do discurso musical, salientando exatamente essas discrepâncias e avaliando suas consequiências dentro do funcionamento da teoria, num exercício crítico em busca de contribuições ou de contradições com a proposta greimasiana.

\subsubsection{Sintaxe profunda}

Ao optar-se por fundamentar uma semiótica musical a partir do processo de silabação visto por Hjelmslev e Zilberberg, sofre-se em contrapartida uma limitação no paradigma das categorias fundamentais. De fato, o modelo hjelmsleviano praticamente nos compele a definir o quadrado semiótico enquanto oposição entre as categorias intenso/extenso, excluindo à primeira vista oposições clássicas como vida/morte, natureza/cultura etc. Há entretanto dois fatores a se considerar a esse respeito.

O primeiro diz respeito à natureza das categorias do nível profundo. Podemos dividir as dicotomias categóricas mais freqüentes em duas grandes classes: a classe temática e a classe aspectual. Por classe temática, entendem-se as categorias formadas por termos que remetem a tematizações, tais como natureza/cultura e vida/morte, estabelecendo uma visão que ordena paradigmaticamente em dois grandes grupos os temas e valores implicados no discurso. Por classe aspectual, temos aquela cujas dicotomias são representadas por termos de caráter processual, tais como intensividade/extensividade, continuidade/descontinuidade, tensão/relaxamento. Categorias dessa classe tendem a ordenar os valores e tematizações sintagmaticamente, estabelecendo uma ótica em que o discurso se apresenta sobretudo como um fluxo de transformações regido por uma pulsação onde se alternam dois tipos antagônicos e complementares de movimentação (contração/expansão, abertura/fechamento Tc).

Enquanto as categorias clássicas propostas por Lévi-Strauss se prestam perfeitamente à investigação do sentido em uma imensa gama de textos verbais, tal adequação não se verifica da mesma forma ao tentar aplicá-las a textos musicais. Em verdade, apenas exemplos bastante esparsos dentro do imenso repertório ocidental parecem se ajustar às oposições tão caras à obra do grande antropólogo e pensador francês, mas mesmo assim fornecendo uma visão sobretudo sintática do percurso gerativo, deixando lacunas a respeito principalmente da dimensão patêmica do discurso. Vale ainda ressaltar que aquelas categorias seriam, na visão de Hanslick, reducionistas ao ponto de merecerem o rótulo de subjetivismos do analista, o qual teria por obrigação, segundo o crítico alemão, preservar toda a abstração do discurso musical no decorrer de sua análise ${ }^{40}$. A questão é que, aprofundando-se na consideração do percurso gerativo de diversos textos pertencentes a diferentes sistemas semi-simbólicos, parece sensato supor que a cada linguagem (musical, verbal, plástica, gestual etc.) corresponda um mundo natural particular (embora nada impeça a existência de uma vasto campo semântico em comum entre elas, sendo a palavra o interpretante ${ }^{41}$ mais freqüente dos outros sistemas), o que implica em última análise a existência de tematizações e figurativizações específicas para cada código, verbal ou não-verbal, sem que essas possam simplesmente ser compreendidas como figuras do plano de expressão. A respeito da dificuldade de lexicalização do universo

\footnotetext{
${ }^{40}$ Hanslick, 1974.

${ }^{41}$ Aqui utiliza-se a acepção benvenistiana do termo "interpretante", e não a peirciana.
} 
semântico musical, o famoso musicólogo conseguiu sintetizar a questão em seu célebre comentário:

As music has no prototype in Nature, and expresses no definite conceptions, we are compelled to speak of it either in dry, technical terms, or in the language of poetic fiction. Its kingdom is, indeed, "not of this world"

Entretanto, se as categorias straussianas, cuja presença é tão marcante na produção artística e literária a ponto de lhes valer a denominação de universais, não apresentam definitivamente o mesmo peso no repertório musical, tal se deve ao fato de perderem em abrangência, no domínio musical, para as categorias de classe aspectual, cuja engenhosa articulação tensiva, como veremos mais adiante, possibilita uma geração de efeitos de sentido passional de tal ordem que resultou na predominância praticamente universal de uma concepção de música como arte por excelência "de expressar sentimentos e paixões por meio de sons". Tal mecanismo de geração a partir de procedimentos de natureza aspectual, vale dizer, foi também intuído por Hanslick, como se pode atestar através de sua observação:

What part of the feelings, then, can music represent, if not the subject involved in them? Only their dynamic properties. It may reproduce the motion accompanying physical action, according to its momentum: speed, slowness, strength, weakness, increasing and decreasing intensity... This is the element which music has in common with our emotions, and which, with creative power, it contrives to exhibit in an endless variety of forms and contrasts $^{43}$.

Vale ainda acrescer que o predomínio de categorias de classe aspectual, conforme discutido anteriormente, implica um caráter pulsatório ao discurso em tudo coerente com a própria natureza da linguagem musical.

Finalmente, como segundo fator a ser relevado, cabe abrir-se uma breve discussão a respeito daquilo que chamaremos de sobrecategorização. Por sobrecategorização, entenda-se o mecanismo pelo qual as categorias fundamentais (pertencentes à classe aspectual) que regem o percurso gerativo de um texto parecem receber um segundo revestimento semântico (passando a assemelhar-se àquelas de classe temática) por força da ação de elementos de sua estrutura discursiva e interdiscursiva. Como é de se esperar, não se trata realmente de uma "metamorfose" das categorias de nível fundamental ao longo do discurso (o que não faria sentido dentro do modelo greimasiano), mas simplesmente do preenchimento de cada uma delas com percursos temáticos contrários. Esse seria o caso, por exemplo, de um texto estruturado sobre a oposição intenso/extenso que, por uma primeira conversão, desse origem aos valores do sistema e que, por sua vez convertidos ao nível discursivo, estabelecessem uma relação de forma que à dupla conversão do elemento intenso correspondesse um percurso temático organizado sobre o tema natureza, e, à dupla conversão do elemento extenso, correspondesse o percurso temático da cultura, seu contrário. Tais correspondências ganham em importância quando, incidindo localmente, correspondem por exemplo a uma sanção (cognitiva ou pragmática) ou então quando se encontram disseminadas ao longo de várias isotopias utilizadas no texto. Assim sendo, pode-se inferir, em última análise, que a detecção de efeitos de

\footnotetext{
${ }^{42}$ Ibid., p.70.

${ }^{43}$ Hanslick, 1974: 37-38.
} 
sentido de oposições semânticas tais como o conflito entre o Homem e o Destino na Sinfonia n.o 5 de Beethoven ou na Sinfonia n.o 4 de Tchaikovski, ou vida versus morte, no final do IV Movimento da Sinfonia n.o 6 de Tchaikovski, dizem respeito a oposições temáticas de nível discursivo, e não verdadeiramente de oposições de nível fundamental.

À guisa de brevíssima ilustração dos pontos de vista defendidos nesse tópico, façamos algumas considerações a respeito da célebre Sinfonia n.o 5, de Beethoven. Como quase todas as sinfonias do século XIX, ela segue basicamente a chamada forma sonata, onde o discurso é gerado pela oposição de dois temas, chamados classicamente de Tema I e Tema II, resultando numa estrutura dividida em três seções básicas: a exposição, onde os temas são apresentados; o desenvolvimento, que corresponde a um desdobramento polêmico entre os dois temas; a reexposição, onde há a reapresentação dos temas e, na subdivisão final dessa seção, chamada coda, a geração do efeito de sentido de sanção, com a "solução" da tensão dramática.

O TEMA I da sinfonia é:

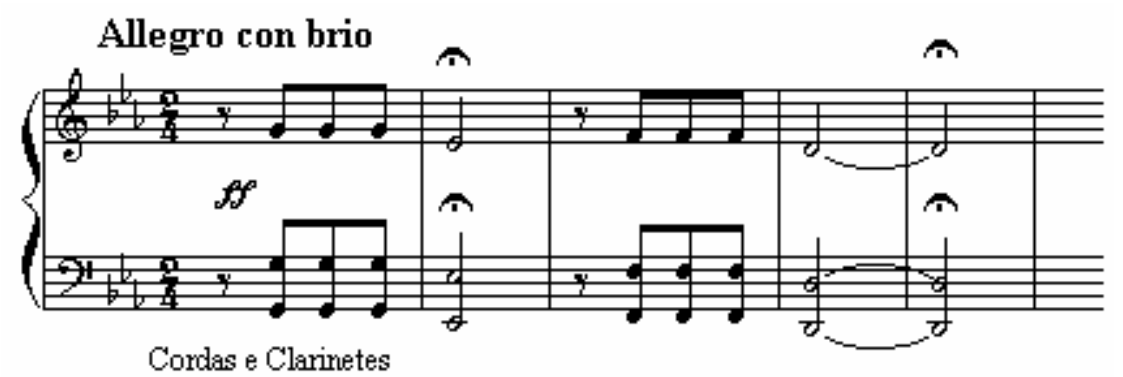

Observando as aspectualizações das modulações tensivas do motivo, verificamos:

a) um movimento geral de fechamento melódico, devido ao seu desenho descendente;

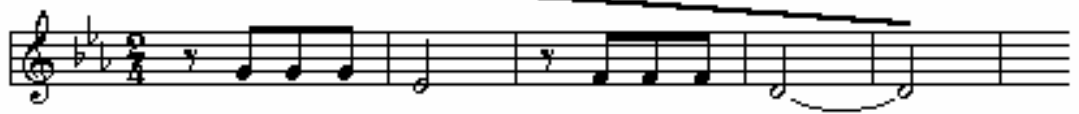

b) o desenho rítmico é formado por pontualidade seguida de duratividade;

c) a intensidade está aspectualizada como excessiva através da indicação de fortissimo $(f \boldsymbol{f})$;

d) a pontualidade e as pausas conferem uma marca de descontinuidade ao motivo

A conversão ao nível narrativo das modulações do devir aponta para a modalização de um dever, devido ao aspecto pontual; de um saber, pela terminatividade; de um poder pela cursividade. O traço de intensidade remete, no campo discursivo, à imagem do sujeito excessivo, freqüientemente associado à figura do herói. A preponderância da pontualidade salienta o dever, enquanto que o poder parece indissociável aqui do traço excessivo, remetendo-o à discursivização enquanto qualidade de um sujeito. Tais características, somadas, dão consistência ao depoimento de Grove, que afirma que Beethoven certa vez aludira ao princípio dessa sinfonia com a metáfora do "destino batendo à porta" 44 , à medida que há vários semas

\footnotetext{
${ }^{44}$ Grove, 1962:151.
} 
em comum entre as características mencionadas e a noção de destino. Para o Robert, o verbete "destin" se define por

puissance qui, selon certaines croyances, fixerait de façon irrévocable le cours des événements ${ }^{45}$.

Vemos aí estampados os traços do poder e do sujeito excessivo na "puissance", do dever na "façon irrévocable" e do saber na afirmação que corresponde à sanção cognitiva pela qual a fatalidade é reconhecida em toda sua dimensão por um observador que é o ponto de origem de toda aspectualização.

Embora aceitável a idéia de uma figurativização do destino, ou, talvez até com maior propriedade, de uma tematização da fatalidade, o que poderia sugerir o conflito fatalidade versus determinação (enquanto vontade humana) como categorias fundamentais do texto, propõe-se aqui um retorno às categorias intensividade versus extensividade para uma melhor compreensão do percurso gerativo do texto musical. No caso dessa sinfonia, podemos reconhecer como intervalo portador dos valores relativos à intensividade no discurso, ou, simplesmente, como elemento intenso, o intervalo de 3.a descendente no princípio do Tema I:

\section{3.a M desc.}

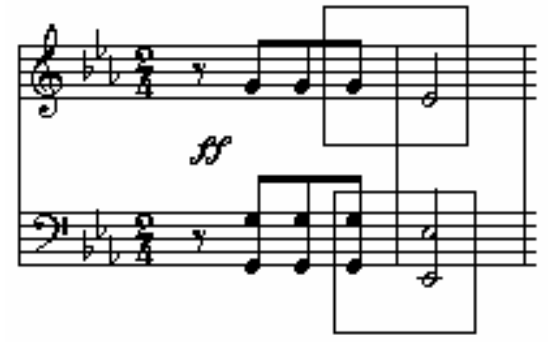

3.a M desc.

Já como portador dos valores extensivos, ou elemento extenso, a repetição do motivo de 3 .a um tom abaixo resulta num intervalo de 4. descendente $^{46}$ :

\footnotetext{
${ }^{45}$ Robert, 1994: 621.

${ }^{46}$ Nesse caso, a 4.a J deriva da soma da 3.a m com um intervalo de 2.a M (um tom). Apesar da extensividade aqui ser gerada a partir do intervalo de 2.a, o decorrer da sinfonia autoriza delegar essa função à 4.a, sua derivada dentro da especificidade desse texto.
} 

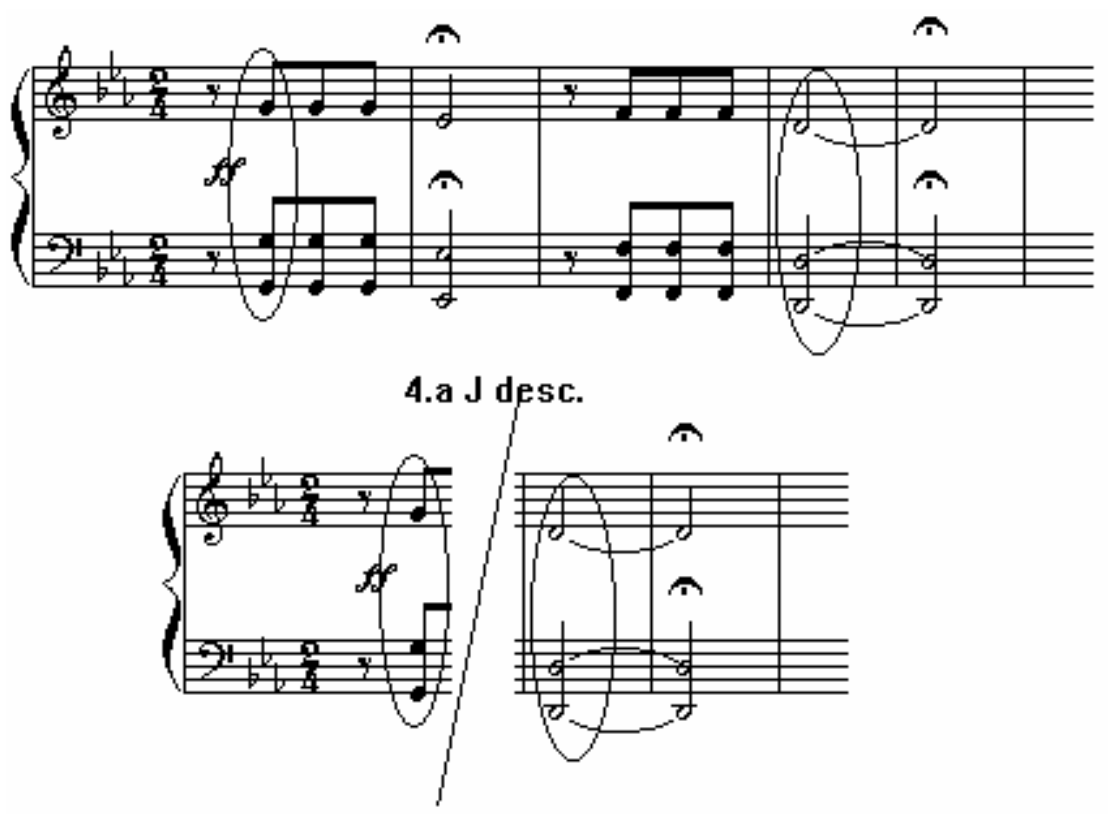

Assim, ainda que esquematicamente, pode-se apresentar imediatamente a leitura de uma dimensão muito mais abstrata do percurso gerativo do texto, apontando para a gênese da extensividade enquanto diluição da intensividade como gesto fundador da espacialidade e temporalidade do discurso. Vale salientar que a gestualidade decorrente dessa dinâmica de nível profundo é totalmente compatível com a figurativização do destino, à medida que a fatalidade consiste num incidente (pontual e intenso) fixando uma cursividade ("le cours des événements"), ou seja, uma intensividade dando origem a uma extensividade.

Detenhamo-nos agora sobre o Tema II:

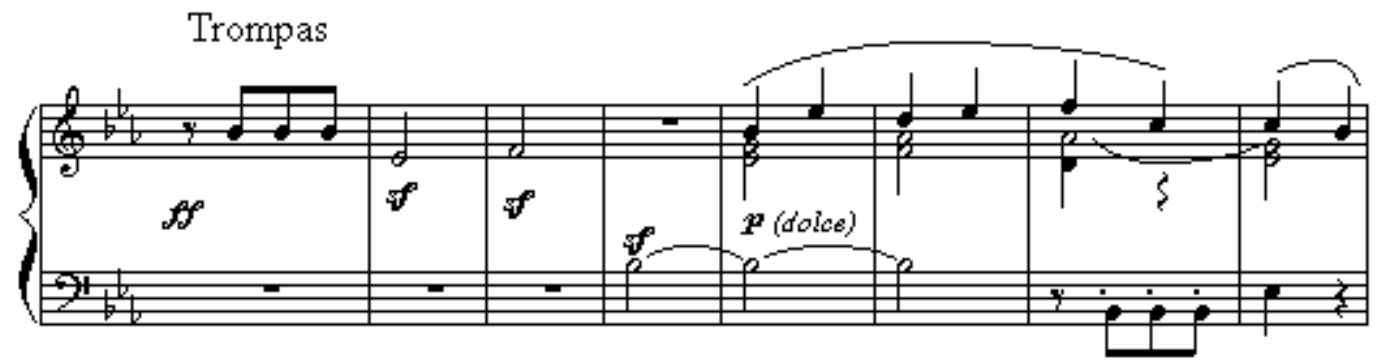

Ele é formado por dois elementos, que chamaremos de II-a:

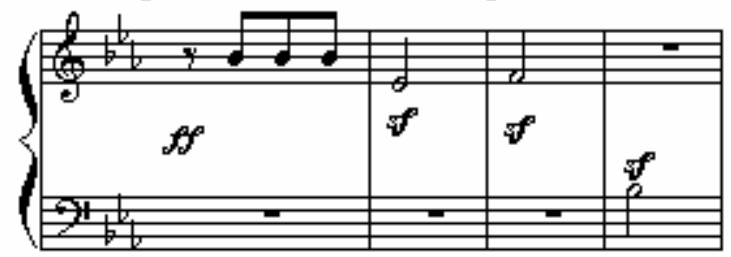

e II-b: 


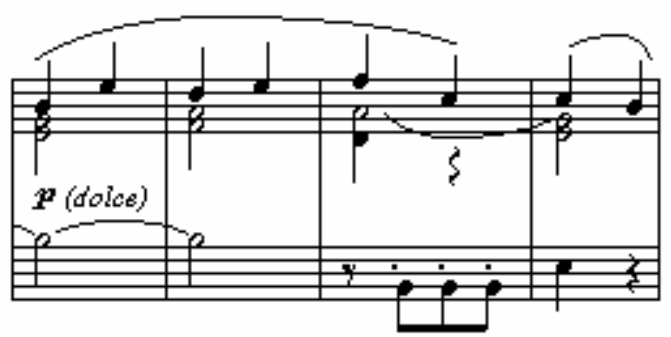

sendo que II-b deriva de II-a, pois a inversão harmônica de:

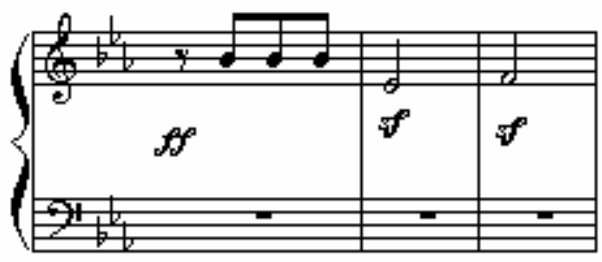

resulta exatamente em:

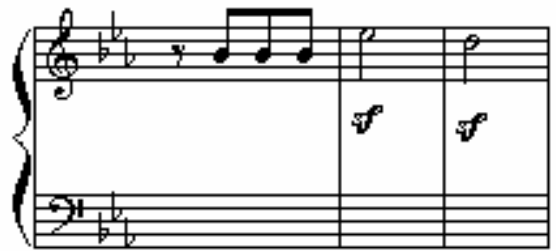

que por sua vez apresenta o mesmo desenho melódico que gera II-b:

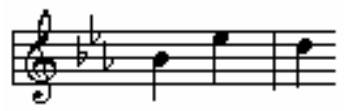

Examinada a relação entre II-a e II-b, verifiquemos agora de que maneira se relacionam os Temas I e II. Embora as considerações tecidas nessa parte do trabalho sejam aparentemente de natureza puramente musical, elas se fazem necessárias à medida que apenas por meio de um mergulho nas peculiaridades do código podemos identificar corretamente as transformações de estado presentes no discurso e, já novamente sob um ponto de visto semiótico, determinar quais os valores que regem a economia do sistema e de que maneira seu fluxo atua no percurso gerativo de sentido.

Como é peculiar à linguagem musical a quase inexistência de um sistema predeterminado de significações, tanto o sentido como o significado se constituem quase que exclusivamente enquanto decorrência da sintaxe de cada texto. É interessante se verificar de que maneira se dá esse processo através da comparação do Tema I com o Tema II-a. Vejamos: 

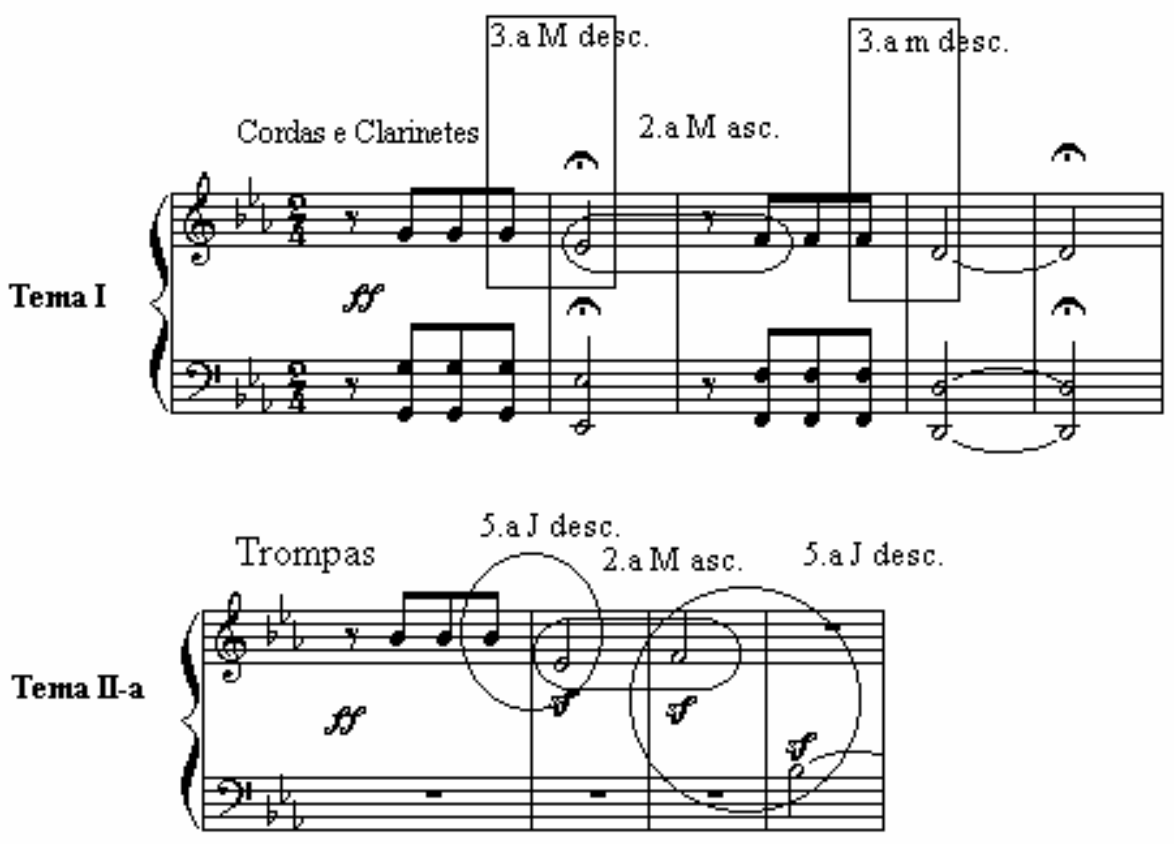

Semelhanças:

a) estrutura: intervalo $x$ - 2.a M ascendente - intervalo $x$;

b) exposição em fortissimo;

Diferenças:

a) $x$ é ocupado, no Tema I, pelo intervalo representante do elemento intenso; no Tema II-a, pelo representante do elemento extenso;

b) no Tema I, o movimento é sustado por fermatas, criando paradas; em II-a, o acento é marcado apenas por um sforzando ( $s f)$;

c) caráter disfórico de $\mathbf{I}$ devido à tensão harmônica sobre uma tonalidade menor e à finalização tensa sobre a dominante contraposto à euforia em II, devido ao relaxamento da tensão harmônica pela apresentação sobre uma tonalidade maior (tônica relativa) e pela finalização relaxada sobre a tônica;

d) predomínio da pontualidade e da descontinuidade em I, contraposto ao predomínio da duratividade e da continuidade em II;

e) o Tema I é apresentado por um grande grupo (todas as cordas mais clarinetes); II-a, apenas pelo naipe de Trompas.

O flagrante paralelismo entre as duas estruturas temáticas indica que a mudança de estado da primeira para a segunda decorre de um fluxo de valores da seguinte natureza: em I, a estrutura actancial se encontrava em conjunção com os valores intensivos do sistema, enquanto que, em II, ela está conjunta com os valores extensivos. Além das observações em a), que apontam inequivocamente para essa conclusão, analisemos as implicações dos outros itens. As fermatas em I indicam uma parada, salientando a intensividade do trecho pela suspensão da espacialidade (vale lembrar Zilberberg: o tempo seria apenas uma contenção do espaço, e o espaço, 
o desdobramento da temporalidade ${ }^{47}$ ) e pela expansão da temporalidade, fato que não chega a ocorrer em II-a. A passagem da disforia para a euforia indicada em c), aferida tanto por questões de genuína tensividade harmônica quanto por uma convenção peculiar à música clássica ocidental (portanto, um aspecto interdiscursivo), indica também um caminho da disjunção à conjunção, acentuada por uma transição das valências da intensividade à extensividade (ver item 1.2). A finalização tensa de $\mathbf{I}$ contraposta à relaxada de II aliada aos aspectos de continuidade e duratividade relevados em d) permitem ainda associar a I um modo de existência virtualizado, e a II, um modo realizado. Por último, o item e) conduz na prática a uma diluição do fortissimo inicial que, antes apresentado pelas cordas, não tem o mesmo corpo exposto apenas pelas trompas.

Para essa breve análise ser menos incompleta, haveria que se comentar mais detalhadamente de que maneira a continuação do Tema I, por seu movimento de abertura, remete também a uma virtualização, salientando a disjuntividade e desenvolvendo o modo de existência do motivo inicial, ao passo que II-b enfatiza os caráteres conclusivos e terminativos, estendendo a realização e conjuntividade presentes em II-a. Tal entretanto estenderia esse comentário para muito além de seu objetivo inicial, que seria simplesmente comentar o funcionamento das categorias de plano profundo no discurso musical, defendendo enquanto processo metodológico a adoção apriorística da oposição inventividade versus extensividade e demonstrando que essa hipótese de trabalho não invalida outras oposições que, na verdade, pertenceriam a outros níveis de geração de sentido que não o fundamental.

Assim sendo, examinemos o que foi apurado até agora:

Verificamos que a oposição determinação (no sentido de poder da vontade e de livre-arbítrio) versus fatalidade é coerente com uma série de aspectos observados nos trechos analisados, mostrando-se consistente o bastante para se sustentar enquanto leitura e concepção da peça em questão. Comentamos da adequação do Tema I com a idéia de um destino imperioso e aterrador esboçado através da pontualidade que aponta para um dever e da fundação da extensividade (inclusive enquanto espacialidade e temporalidade) a partir da intensividade, como o marco que transforma o curso do devir. Observamos ainda que, quando se trata do Tema II, os aspectos conclusivos e terminativos presentes no trecho apontam para um modo de existência atualizado e realizado, coerentemente com a idéia de uma vontade atualizada e realizada de um Homem que se crê senhor de seu destino. Notamos por último haver oposições de diversas naturezas entre os Temas I e II no que diz respeito aos respectivos planos de expressão e, conseqüentemente, através de Hjelmslev, também quanto a seus respectivos conteúdos, permitindo identificar em várias dessas oposições algo da contrariedade entre determinação e fatalidade. Fica entretanto ao mesmo tempo patente o quanto essa dicotomia fica a dever à oposição fundamental intensividade versus extensividade no que tange à sua abrangência dentro do percurso gerativo, à medida que esse último binômio, ao contrário do outro, permite vislumbrar claramente os diversos patamares da significação juntamente com os processos de conversão e convocação responsáveis pela geração de sentido propriamente dita e ainda compreender a oposição determinação versus fatalidade em sua exata medida, ou seja: na instância da significação onde as transformações de estado são assumidas por um sujeito "Homem" ou por um anti-sujeito "Destino",

${ }^{47}$ Zilberberg, 1988:104. 
dando origem a uma oposição temática, e não fundamental, e que faz parte do rol de leituras possíveis do texto.

Fica assim ilustrada a proposta metodológica de adoção apriorística das categorias intensividade versus extensividade para a análise semiótica do texto musical e ressalvada a plena possibilidade de existência de outras oposições em outros níveis de significação, principalmente de natureza discursiva em geral e temática em particular, sem que isso implique a invalidação da hipótese inicial.

\subsubsection{Semântica profunda}

É sobretudo a partir de sua dimensão semântica que o mito da música enquanto linguagem universal se esvazia, dando lugar a uma conceituação da música sobretudo enquanto fenômeno lingüístico de ocorrência universal. Prenhe de gestualidades, a música freqüentemente gera a impressão de se fazer compreender; como a mímica, apresenta gestos cuja leitura parece inequívoca, mas que na verdade padece dos mesmos mal-entendidos dos falsos cognatos, submetidos à implacável diversidade cultural e às infinitas hierarquias de valores que caracterizam cada comunidade interpretativa (para não falar de cada indivíduo).

Há três elementos principais a se relevar numa abordagem da dimensão semântica do nível profundo. Esses elementos são: a foria, a tensividade e a aspectualização. Discutiremos agora algumas das principais questões relativas a esse patamar do percurso gerativo que se colocam ao semioticista ao longo da análise de um texto musical. Examinemos inicialmente a questão da foria. Seja o percurso:

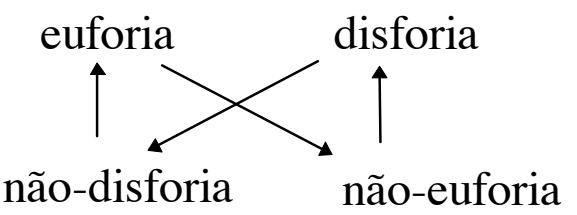

Esse percurso, que, como é de se esperar, é coberto em cada texto, apresenta grosso modo algum tipo de codificação e estratificação própria para cada cultura. Tais convenções entretanto não desobrigam o analista nem de aprofundar o quanto possível seu conhecimento da cultura em que se insere a peça a ser estudada nem muito menos de um constante exercício de sua sensibilidade e intuição, visando captar cada nuance de sentido, cada pequena variação de foria marcada no texto. No caso do ocidente, por exemplo, dois fatores principais concorreram para que as tonalidades menores fossem associadas à disforia e as maiores, à euforia, ambos devendo sua origem à interação entre a música e discursos de outra natureza, representando assim portanto a consolidação de determinadas relações interdiscursivas. $\mathrm{O}$ primeiro fator se originou da concepção pitagórica de música (já discutida em item anterior), à partir da qual se deduz ser o acorde maior matematicamente mais "equilibrado", e portanto, "harmônico", que o menor, levando o dualismo ocidental do medievo a concluir que, se um expressa harmonia e equilíbrio, o outro expressa necessariamente desarmonia, desequilíbrio e angústia (ainda que em grau tolerável, escapando de proibições sistemáticas como a do trítono, intervalo musical repudiado pela Igreja e conhecido na idade média como diabolus in 
musicae $^{48}$, pretensamente pela dificuldade técnica de sua emissão no canto). O segundo fator é de ordem consuetudinária, e teve origem na opereta do século XVII. À medida que a opera buffa consolidava-se como nova forma de expressão artística, algumas convenções foram surgindo nessa forma de teatro musical que tiveram em última análise conseqüências marcantes na própria expressão musical, trazendo dos palcos para as salas de concerto codificações musicais a princípio de alguma forma relacionadas a performances cênicas. $\mathrm{O}$ uso de escalas maiores e menores para indicar respectivamente euforia e disforia foi dessa forma solidificando-se principalmente com o amadurecimento da opereta, a partir do século XVIII, e difundindo-se cada vez mais a partir dessa época, tendendo à categoria de convenção do código. Entretanto, em outras culturas em permanente contato com a européia, como as culturas eslava, hebraica e cigana, tal convenção não é em absoluto válida, e sua aplicação por um analista desavisado poderia dar origem a leituras extremamente equivocadas.

Outra tendência a ser tratada com bastante cautela é a de relacionar foria com andamento. Por essa lógica, músicas "alegres" tenderiam a ser mais "rápidas" que músicas "tristes". Apesar de fundar-se numa gestualidade quase universal, esse conceito esbarra em obras que exprimem um repertório emocional mais complexo e, mais ainda, o conceito de "rapidez" de um andamento sofre variações culturais enormes. Assim, por exemplo: dentro do Gagaku ${ }^{49}$, a composição Etenraku é certamente mais contemplativa, lenta e menos eufórica que Batô; entretanto, a alegria de Batô dificilmente poderá ser captada por ouvidos ocidentais contemporâneos que, dentro de nossos parâmetros, provavelmente considerariam a peça, além de um tanto estranha, lenta e desanimada. Da mesma forma, um jovem acostumado a ouvir rock tende a achar um alegre minueto algo no mínimo tedioso.

Fica claro dessa maneira que basear ${ }^{50}$ a abordagem analítica semiótica de um texto musical na apreensão de elementos fóricos é um procedimento um tanto quanto arriscado, embora extremamente sedutor, à medida que permite ao analista partir de uma das impressões mais imediatas (e intelectualmente menos exigentes) que uma música oferece a um ouvinte qualquer. De fato, mesmo quando podemos nos

\footnotetext{
${ }^{48}$ Ao que tudo indica, a proibição do trítono se deveu à sua associação com a música árabe, em que aparece com freqüência e prqticamente como elemento característico. O império árabe, vale lembrar, representava na idade média uma civilização em todos os aspectos muito mais avançada que a européia, e um inimigo poderoso que, se não conseguiu transpor os Pirineus, dominou as rotas do mediterrâneo e venceu os cristãos em quase todas as cruzadas. Para a Igreja, tratava-se de um inimigo religioso, e temia-se muiito que a liberalidade e sensualidade da cultura árabe da época (quando em contraste com sua contemporânea européia), através de suas músicas e danças, seduzisse os fiéis, levando a Igreja a uma curiosa forma de xenofobia onde os traços da presença do outro são negados e sistematicamente apagados. A música dos menestréis, o alaúde e sua família, a rabeca que originou o violino e a família das cordas são alguns exemplos de elementos trazidos à Europa por influência árabe e que, por ter sido inevitável sua disseminação, tiveram sua origem histórica apagada da memória cultural ocidental por vários séculos.

${ }^{49}$ Música Clássica do Japão, de origem chinesa.

${ }^{50} \mathrm{~A}$ objeção aqui colocada não se refere, obviamente, à estenção da análise à dimensão fórica, o que é desejável e até inevitável, mas adverte em relação ao alto risco de se cair em subjetivismos ao se utilizar como ponto de partida uma apreensão da foria para a realização da análise de um texto dessa natureza. Embora não haja como fugir completamente à subjetividade na análise musical, devido à ausência de uma codificação geral da linguagem, convém evidentemente evitá-la o quanto possível ao investigar o percurso gerativo de um texto musical, de modo a evitar reducionismos que venham a resultar numa visão limitada e canhestra dos efeitos de sentido e de seu processo de geração numa partitura.
} 
apoiar em textos metalingüísticos onde um pesquisador de reconhecida competência, ou mesmo o próprio autor, comenta verbalmente uma peça musical, parece bem mais seguro iniciar um exame da dimensão semântica do nível profundo através de um parâmetro com um grau menor de subjetividade: a tensividade.

Partamos novamente da música ocidental. Um dos primeiros teóricos a conceber a música como um jogo onde se alternam tensão e relaxamento foi Joseph Fux, que em seu manual de contraponto e composição Gradus ad parnassum ${ }^{51}$, publicado pela primeira vez em Viena no ano de 1725, orienta o jovem músico no sentido de estar atento aos diversos graus de consonância e dissonância (p.97) e de sempre buscar a "resolução" dessas últimas na consonância de maior grau de perfeição (p.56). Data da mesma época (1722) o primeiro grande tratado prático sobre harmonia $^{52}$, onde Rameau lança as bases para uma compreensão mais pormenorizada das nuances de tensão e relaxamento obtidas pela utilização de diferentes recursos da linguagem tonal. Tal estudo chega ao seu apogeu com Schoenberg em suas duas obras principais: o Theory of harmony ${ }^{53}$ (1911) e o Structural functions of harmony ${ }^{54}$ (1948), onde o autor analisa em profundidade a questão da harmonia, fornecendo amplos subsídios para uma avaliação de suas implicações tensivas no discurso musical.

Também gradações de dinâmica freqüentemente repercutem diretamente na tensividade de um trecho musical. Grosso modo, pode-se relacionar diretamente grau de dissonância e intensidade com tensividade. O percurso tensivo desenvolve-se a partir das categorias tensão versus relaxamento da seguinte forma:

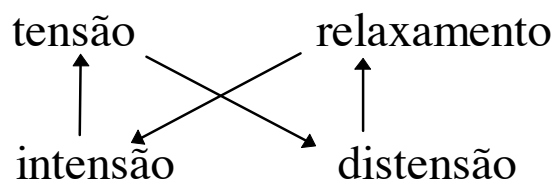

Como ilustração de uma análise levando em conta os elementos tensivos de um texto musical, tomemos o trecho inicial da Sonata Op.13 n.o 8 de Beethoven, também conhecida como Sonata Patética:

\footnotetext{
${ }^{51}$ Fux, 1971.

${ }^{52}$ Rameau, J-P. Treatise on harmony. . New York, Dover, 1971.

${ }^{53}$ Schoenberg, 1978.

${ }^{54}$ Schoenberg, 1969.
} 

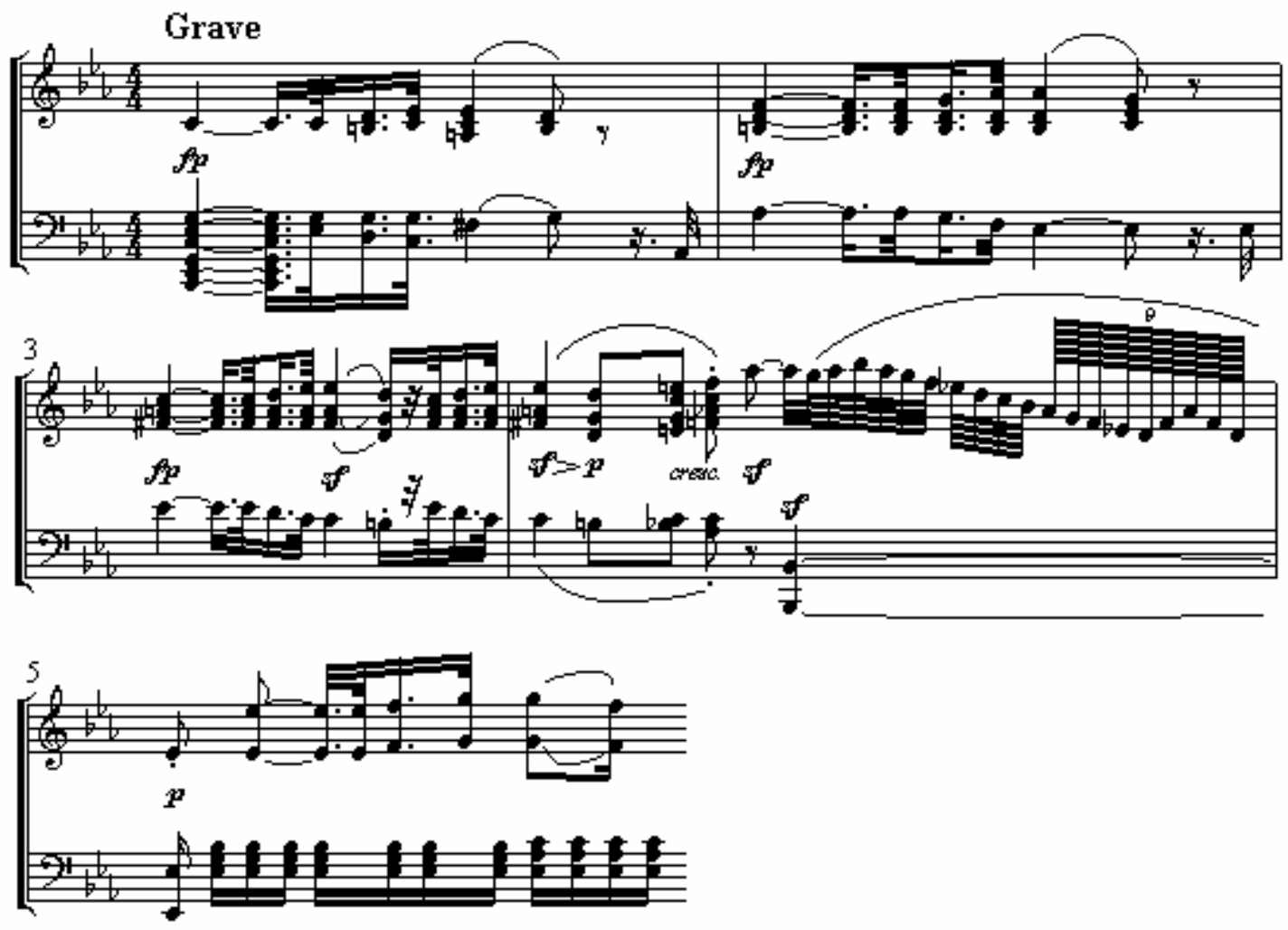

Aproveitando o ensejo para aplicar também outros pontos de vista defendidos ao longo deste trabalho, identificaremos inicialmente os intervalos que representam respectivamente as categorias de extensão e intensão no texto. Observase que o acorde inicial perpetua-se no movimento ascendente de 3.a, indiciando ser esse intervalo o portador dos valores emissivos. A mudança de estado no penúltimo tempo do compasso 1 se faz notar pela alteração de direcionalidade melódica e pela transformação harmônica que culmina com o acorde de dominante, apontando o intervalo de 2.a que marca esse segmento como elemento intensificador e polarizador dos valores remissivos do discurso. Podemos assim entender a dinâmica do compasso 1 como: elemento intenso - extensão (diluição) - intensão, sendo que o processo de extensão é promovido pela aquisição dos valores emissivos pelo intervalo de 3 a e a intensão, pela aquisição de valores remissivos através do intervalo de 2.a:

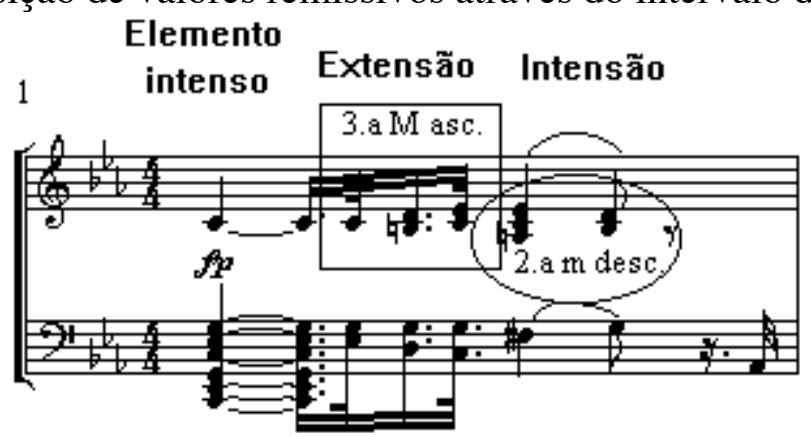

Fato semelhante ocorre no compasso 2, criando-se assim uma pulsação:

Compasso 1

Compasso 2

elemento intenso - extensão - intensão - elemento intenso - extensão - intensão 
Evidencia-se assim desde já o processo de silabação que, conforme discutido anteriormente, é o grande elo de ligação entre o plano de expressão e o plano do conteúdo a partir do qual fundamenta-se uma leitura semiótica do texto musical. No presente caso, sua estrutura silábica é passível de representação pelo seguinte gráfico:

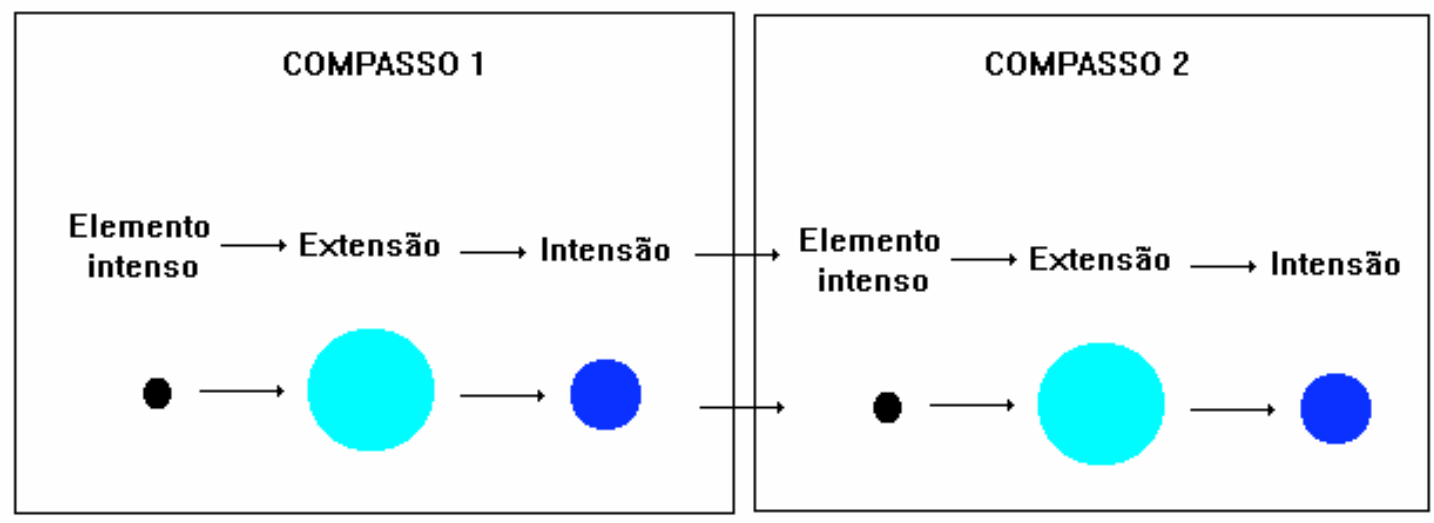

No compasso 3, o ritmo de apresentação da estrutura silábica básica sofre uma aceleração (cujas causas discutiremos logo adiante ao estudar a tensividade propriamente dita do trecho em questão):

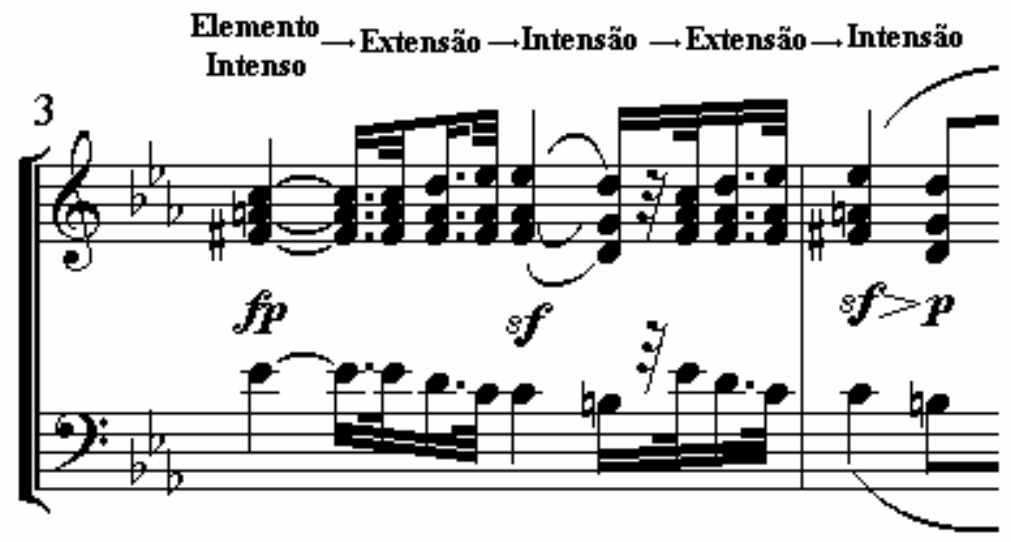

Podemos visualizar a pulsação da silabação (que chamaremos de agora em diante de ritmo profundo) do compasso 3 através do diagrama:

\section{COMPASSO 3}
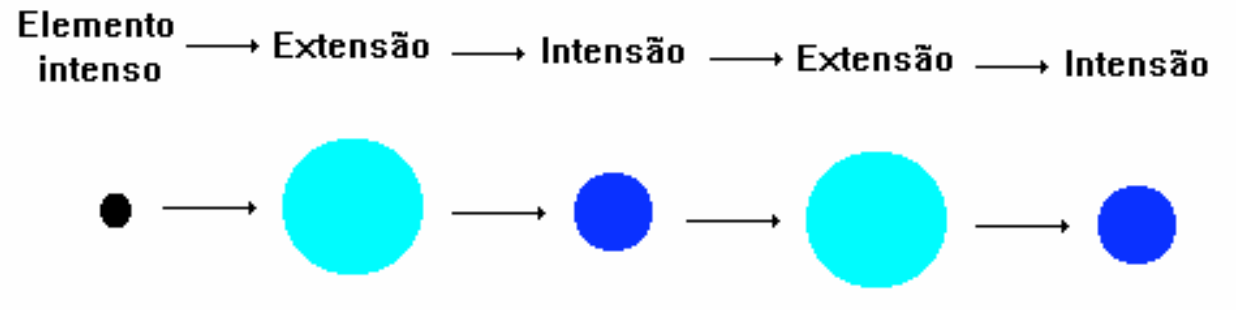
No compasso 4, a seqüiência é quebrada através de uma mudança de estado introduzida por um intervalo de 2.a, representante do elemento intenso, que se sobrepõe a outro, gerando um intervalo de 3.a. Dessa transformação do elemento intenso em elemento extenso resulta um novo predomínio dos valores de extensão, cuja aquisição se discursiviza através da súbita espacialização pela figura melódica em semi e quartifusas, e que se resolve por sua vez através de outra mudança de estado, marcada a nova discretização pelo elemento portador dos valores remissivos do sistema (intervalo de 2.a), culminando finalmente com a chegada à tônica relativa na cabeça do compasso 5:

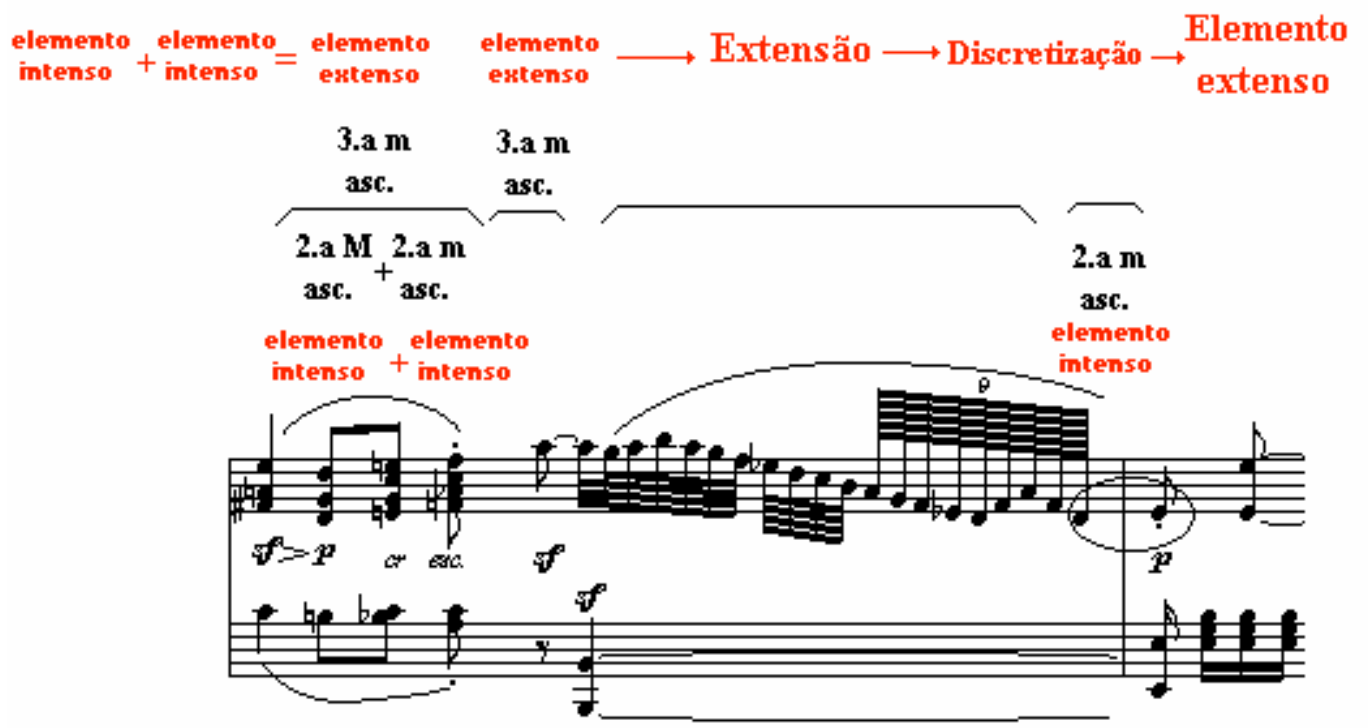

Feito assim um breve levantamento da sintaxe fundamental e de seus desdobramentos estruturais enquanto ritmo profundo, bem como apontados alguns pontos de mudança de estado, revelando introdutoriamente alguns aspectos dentro já de uma perspectiva narrativa, observemos agora o comportamento da tensividade propriamente dita no trecho apresentado e quais suas principais implicações estruturais no percurso gerativo.

A tensividade, no que tange ao discurso musical, manifesta-se de diferentes maneiras, sendo que as principais a serem relevadas no presente exemplo são: dinâmica (a intensidade ou "volume" do som), harmonia (sendo que a tensão harmônica será aqui entendida enquanto distanciamento da tonalidade principal) e celeridade (a aceleração ou desaceleração no sentido semiótico a partir da quantidade de acontecimentos por unidade de tempo). Representando o aumento de tensão por $<$ e seu relaxamento por $>$ e seguindo os parâmetros propostos, iniciemos atentando para o compasso 1. Sob o aspecto dinâmico, o $\boldsymbol{f} \boldsymbol{p}$ determina uma acentuação que se dilui, mantendo-se basicamente estável pelo resto do compasso, exceto por uma pequena intensão logo distendida no 3.o tempo. Seu comportamento portanto é: 


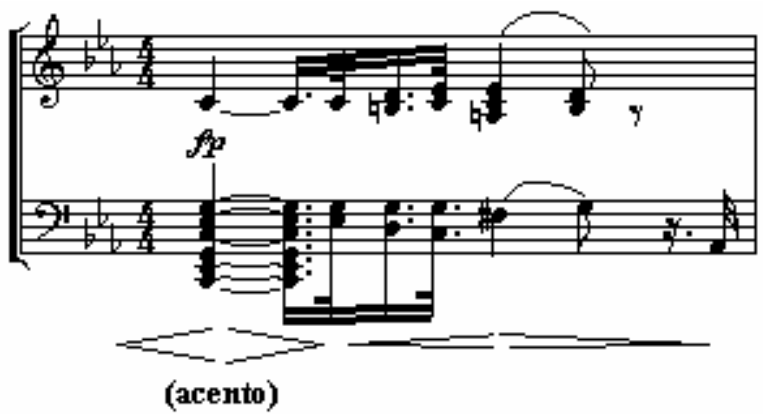

Já quanto à celeridade, observamos, além do acento no 1.o tempo, um outro no 3.o tempo, causado pela súbita desaceleração de fusa para semínima:

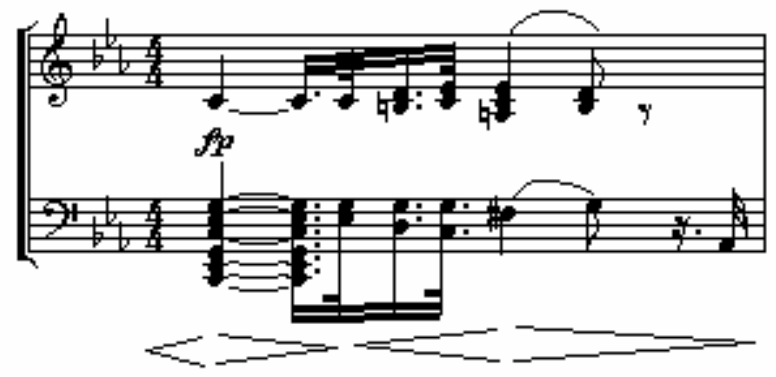

Uma abordagem mais detalhada se faz necessária ao nos depararmos com a perspectiva harmônica, tanto por sua notável importância no que tange à música ocidental quanto pelo instrumental teórico com que se pode contar, levando-se em conta em especial os estudos de Schoenberg a esse respeito. No compasso 1, há três acontecimentos harmônicos: o acorde de tônica sobre o I grau, o acorde de dominante sobre o V grau e o acorde de 7.a diminuta sobre o IV grau, criando um nível crescente de tensão pelo afastamento da tonalidade e uma pequena distensão do 3.o para o quarto tempo. Chamemos esses três patamares de tensão respectivamente de nível da tônica (t), nível da dominante (D) e nível da diminuta $(\varnothing)$. Temos assim a seguinte representação gráfica:

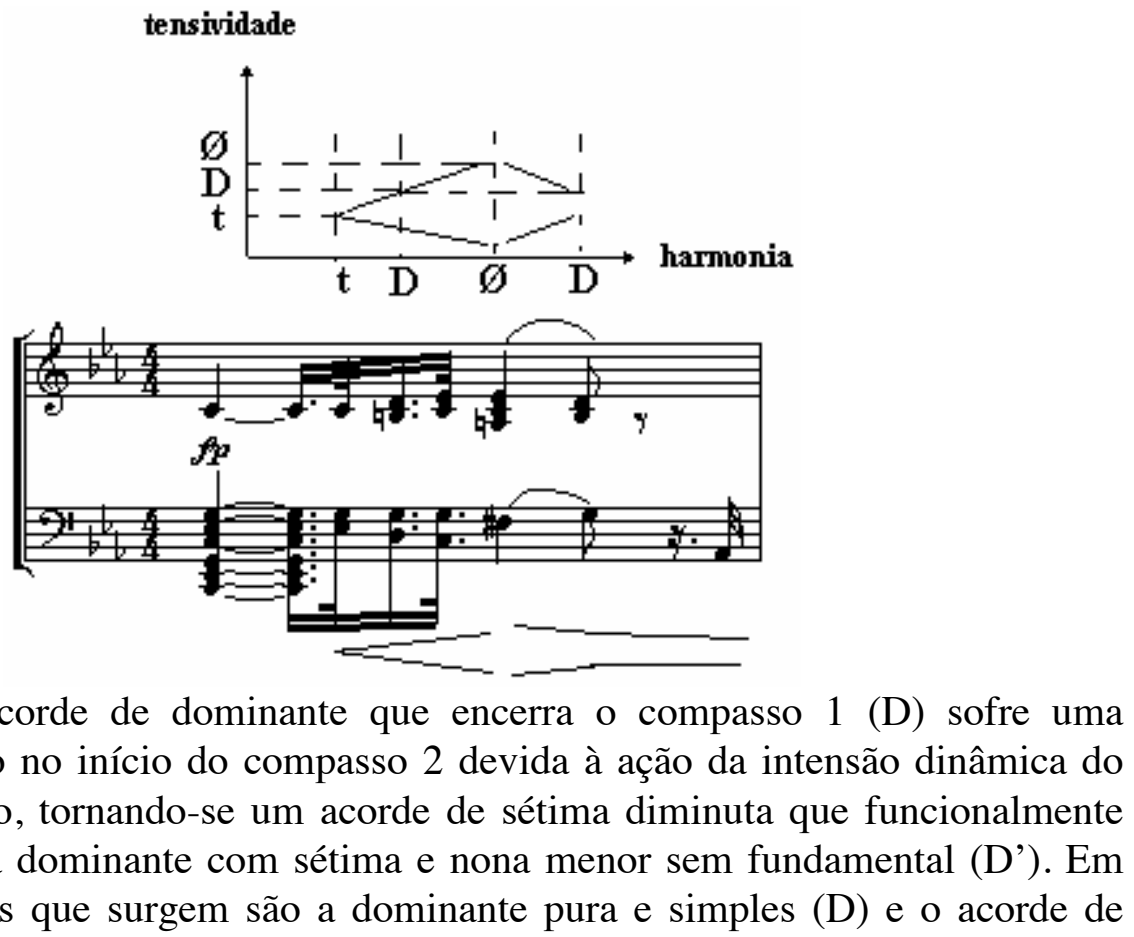


sexta sobre a tônica com appogiatura (t" - t'), o que caracteriza o nível de tensão desse compasso, em última análise, como basicamente decrescente, fechando a abertura iniciada no compasso anterior e resultando na definição de uma silabação tensiva entre os dois compassos:

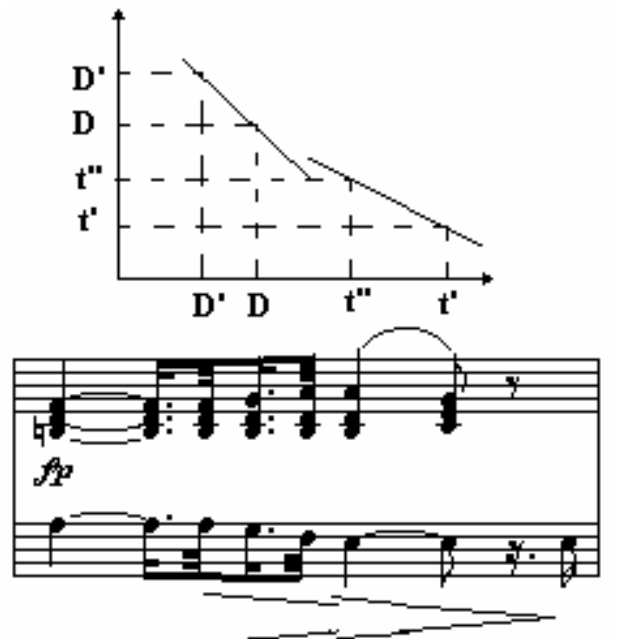

Tensividade

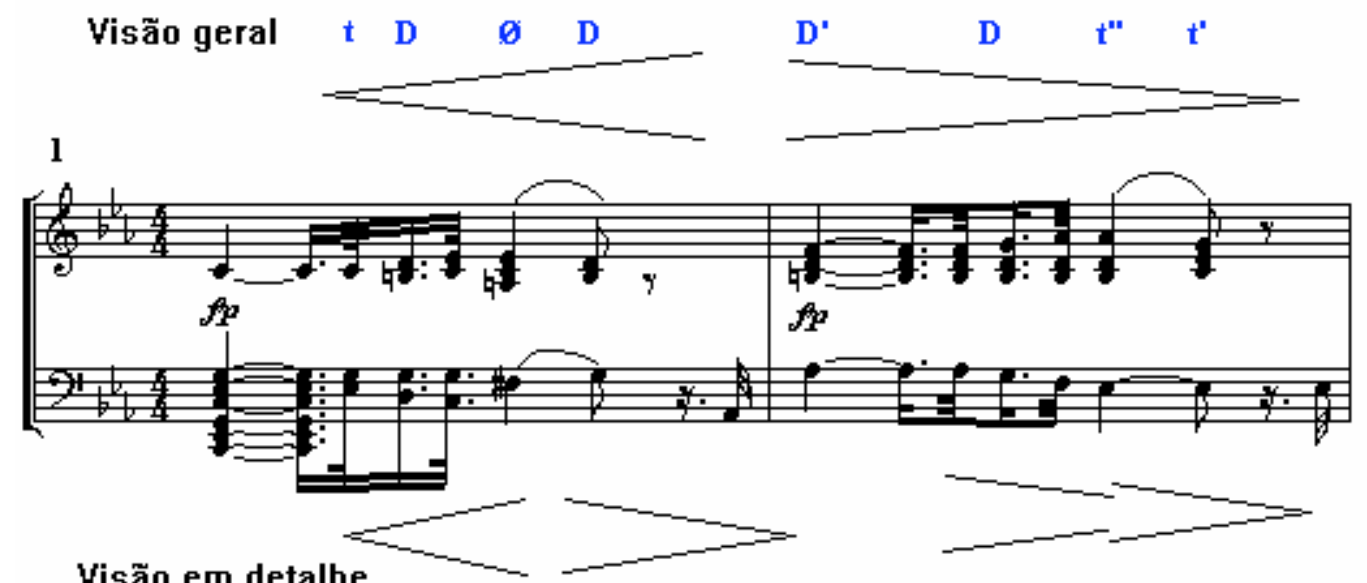

$\mathrm{O}$ acorde de sexta sobre o I grau que encerra o compasso $2\left(\mathrm{t}^{\prime}\right)$ é transformado pela intensão, dando lugar ao acorde de sétima diminuta sobre o IV grau (Ø) que inicia o compasso 3. Aparece em seguida o acorde de dominante da dominante $[\boldsymbol{\bigotimes}]$, e, novamente, a diminuta, agora intensificada pelo sforzando $(\boldsymbol{s} f)$ do 3.o tempo, resolvendo-se finalmente no acorde de dominante (D) no 4.0 tempo, intensificado pela curta duração pedida pelo ponto de staccato. O nível de tensão harmônica exibido nesse compasso, superior aos demais, manifesta-se ainda discursivamente por uma aceleração temporal, onde a pausa quase desaparece e repete-se logo em seguida a mesma frase, causando um deslocamento do tempo que faz com que o segundo acorde de dominante apareça no segundo tempo do compasso 4 , onde se inicia a próxima figura melódica. Vejamos a curva de tensividade no gráfico: 


\section{tensão}

(harmônica e dinâmica)

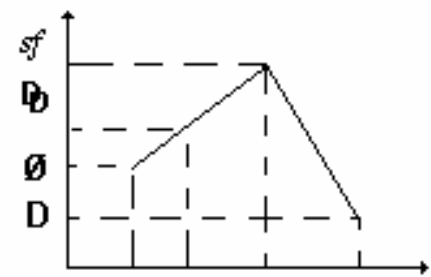

G D D

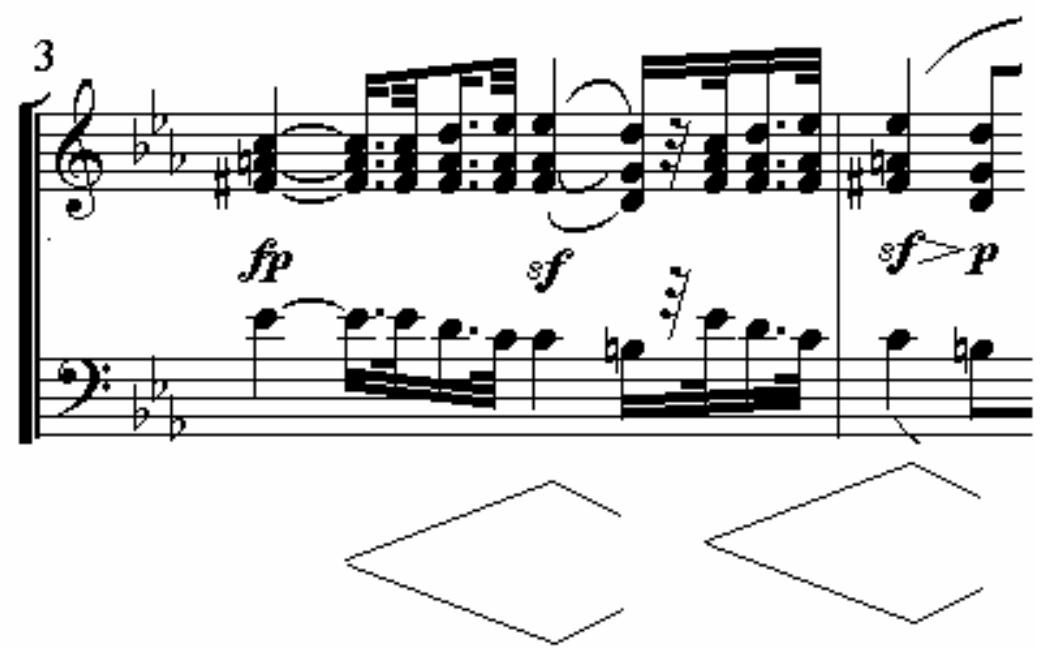

Antes de proceder com o restante da análise, cabe agora tecer um importante comentário, talvez aquele de maior relevância, complexidade e interesse em nível de pesquisa semiótica. Trata-se de observar uma relação entre a curva tensiva do compasso 1 enquanto microestrutura e a curva tensiva resultante dos compassos 1 , 2 e 3 enquanto macroestrutura. Retomemos a primeira frase:
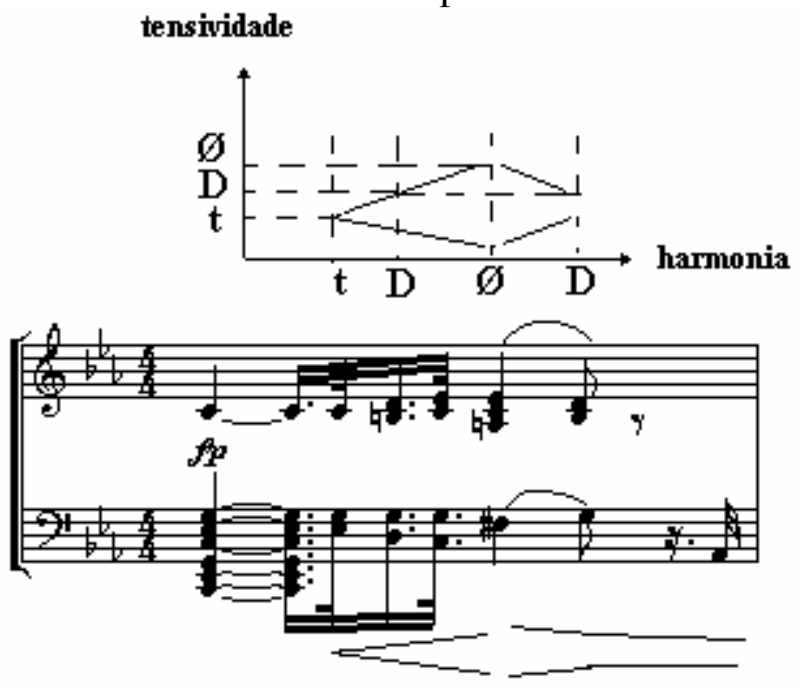

Percebemos que ha três níveis crescentes de tensão: o da tônica (t), o da dominante (D) e o da diminuta (Ø), e em seguida uma resolução, decrescendo novamente a tensividade para o nível da dominante (D). Em nível macroestrutural, notamos que o compasso 1 inicia-se e é regido pelo acorde de tônica (t); que o 
compasso 2 começa com um acorde derivado da dominante, a que chamamos D', e por ele é regido; e, finalmente, que o compasso 3 parte de um acorde de diminuta $(\varnothing)$ e se comporta de maneira harmonicamente análoga aos anteriores. Notamos ainda que, embora o nível de tensão do compasso 2 seja descendente, tanto o patamar inicial quanto o final são superiores ao do compasso anterior, o que nos permite afirmar que o nível geral de tensão cresce do compasso 1 para o 2; e que o compasso 3 dá continuidade de maneira evidente a essa intensificação. Ora, fica assim patente a analogia entre o comportamento tensivo da micro e da macroestrutura. Vejamos por fim se a analogia é completa, analisando a curva tensiva do compasso 4.

Após a finalização da repetição da frase anterior, que toma o primeiro tempo do compasso e metade do segundo, o intervalo ascendente de 2.a, correspondente ao elemento intenso e portador dos valores remissivos, chega ao limite da tensão, provocando uma mudança de estado discursivizada espacialmente por um processo de modulação harmônica que conduzirá transitoriamente à tonalidade correspondente à tônica relativa (Tr). Tal processo inicia-se por um acorde de dominante sobre o I grau que apresenta a função de dominante da subdominante, e que indicaremos por (D"), ao qual se segue a própria subdominante (s), atingida também pelo intervalo de 2.a e com as mesmas implicações descritas. A intensão provocada pelo afastamento da tonalidade repercute também dinamicamente, produzindo um crescendo que culmina com um esforçando que marca o acorde de subdominante (s) e o que se lhe segue. Esse último é um acorde de dominante sobre o VII grau da escala menor e, como todo acorde de transição modulatória, apresenta uma leitura no contexto anterior e outra no seguinte, tratando-se semioticamente de um conector isotópico (em verdade, o conceito de tonalidade é representado com bastante precisão pela noção de um lugar harmônico, um tópos, correspondendo consequientemente a modulação harmônica à passagem de um tópos a outro). $\mathrm{O}$ acorde de si bemol com sétima, a partir da tonalidade de dó menor, é visto funcionalmente como subdominante da subdominante; já em mi bemol maior, trata-se da dominante da nova tonalidade, que, nesse caso, é simplesmente a tônica relativa (Tr) da anterior, o que simplifica a questão, permitindo-nos chamar o acorde em questão simplesmente de dominante da tônica relativa ( ${ }^{(\mathrm{Tr})}$. Há aqui um fenômeno interessante a se notar. Por não ter havido ainda uma cadência completa que confirmasse a tonalidade, essa não está de fato, até esse ponto do texto, definida. Pertencendo as tonalidades de dó menor e mi bemol maior ao mesmo campo harmônico, a cadência fá menor (s) - si bemol ( $\mathrm{T}_{\mathrm{r}}$ ) - mi bemol (Tr) induz à falsa noção de se ter confirmado a tonalidade em mi bemol maior que, no mesmo campo, apresenta nível de tensão inferior à de dó menor, evidenciando-se assim, finalmente, um processo de distensão que se inicia no quarto tempo do compasso, cuja espacialização melódica já foi comentada anteriormente, e que culmina por sua vez na cabeça do compasso 5 com o acorde de tônica relativa $(\mathrm{Tr})$, dinamicamente apresentado em piano $(\boldsymbol{p})$ e que caracteriza o estado final com de relaxamento. 


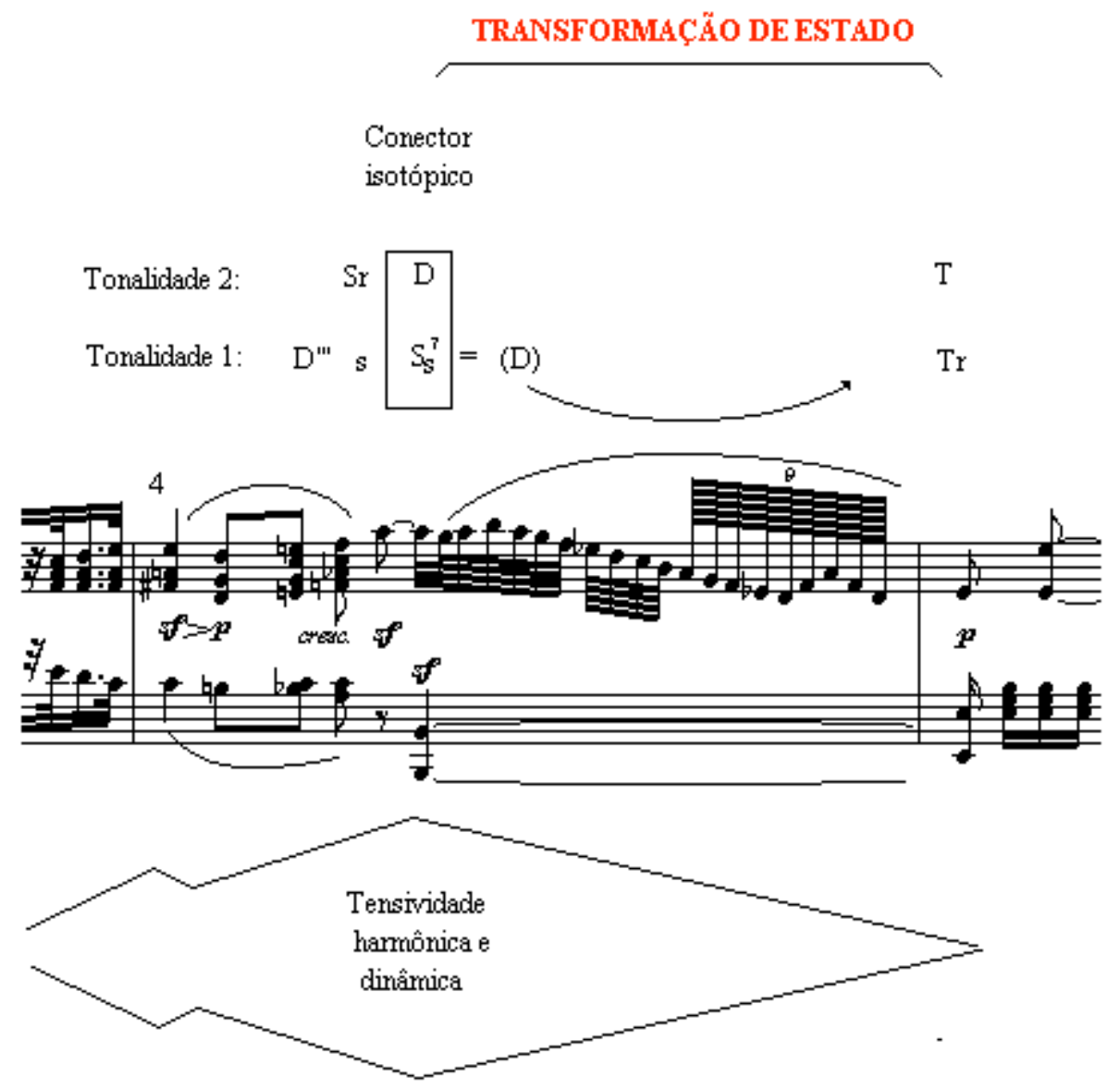

Voltando agora à comparação entre micro e macroestrutura, observa-se finalmente que as estruturas tensivas são de fato análogas, pois ambas apresentam uma intensificação que culmina com uma mudança de estado harmônico (no primeiro caso, a introdução de um acorde dissonante; no segundo, uma mudança de tonalidade) e à qual se segue uma distensão e relaxamento. A esse tipo de analogia (especialmente de natureza tensiva) entre os diferentes graus de organização estrutural do discurso chamaremos estrutura concêntrica, e não há como exagerar sua importância em nossa pesquisa sobre o percurso gerativo de sentido musical, conforme mostraremos ao longo deste trabalho. Pode-se entretanto lançar desde já a hipótese de que a macroestrutura seja gerada a partir da microestrutura no que tange, por exemplo, a seu padrão de comportamento tensivo, o que inaugura imediatamente uma nova perspectiva do estudo de percurso gerativo na música. Fora isso, verificamos ainda que a intensificação sobre o estado máximo de tensão (no exemplo dado, as regiões referentes ao acorde de diminuta $\emptyset$ ) resulta em transformação de estado, com implicações imediatas na conversão da curva tensiva ao nível narrativo.

Através desse exemplo, percebemos que a direcionalidade (ou gradiente) da tensividade tem um importante papel no delineamento da estrutura narrativa de uma composição. De fato, cada mudança de estado é atingida apenas após alcançado um dado grau de tensão, o que induz à idéia de que haja uma relação também entre tensividade e aquilo que a semiótica define como modos de existência, ou mais precisamente, entre variação tensiva e aquisição de competência. Podemos a partir desse princípio finalmente propor um caminho para preencher as lacunas deixadas pela análise schenkeriana, um modelo essencialmente estruturalista de 
análise do discurso musical desenvolvido na primeira metade desse século por Heinrich Schenker e difundido posteriormente por vários de seus discípulos, destacando-se dentre eles a figura de Felix Salzer. Embora represente um formidável avanço no campo da teoria musical, constituindo-se por muitos anos como o mais arrojado modelo concebido para a investigação do sentido no discurso musical, o modelo schenkeriano ainda hoje é freqüentemente julgado mais por suas deficiências que por suas conquistas numa área relativamente inexplorada do conhecimento. Numa breve síntese dos aspectos que mais nos interessam no momento, o teórico austríaco denomina "estruturais" os elementos do discurso que marcam transformações de estado, e simplesmente "prolongamentos" tudo aquilo que não for estrutural, ou seja: abandona-se toda a riqueza de sentidos do percurso que conduz um estado a outro afim de se propor uma audição "estrutural", voltada unicamente, em termos semióticos, para o estudo da sintaxe narrativa do texto musical. Tudo leva a crer, entretanto, que tal omissão deveu-se não ao menosprezo da diversidade e importância de todo o conjunto de elementos classificados como prolongamentos, muito menos ao comodismo de quem crê ter esgotado um assunto de tal complexidade, mas sobretudo à falta mesmo de um instrumental teórico que já em seus primeiros passos pudesse dar conta de toda a problemática do sentido em um texto musical, devendo-se ainda levar em conta o pesodas idéias de Hanslick, que acusava de reducionista e subjetivista qualquer especulação semântica no campo da música. Consciente da limitação do modelo, o próprio Salzer ressalva:

It is wrong to assume, however, that finding the structural framework constitutes the sole purpose of this approach. On the contrary, structural hearing implies much more. It enables us to listen to a work musically, because by grasping the structural outline of a piece we feel the full impact of its prolongations which are the flesh and the blood of a composition. Thus the structural outline or framework represents the fundamental motion to the goal; it shows the direct, the shortest way to do this goal. The whole interest and tension of a piece consists in the expansions, modifications, detours and elaborations of this basic direction, and these we call the prolongations. Their broad, complex and bold unfoldings and their artistic coherence can only be grasped and fully appreciated, however, if their basic direction (comprising the structural framework) has been understood. In the reciprocity between structure and prolongation lies the organic coherence of a musical work. ${ }^{55}$

Em verdade, as idéias do próprio Hanslick deveriam ser compreendidas como resposta aos arroubos e exageros típicos do romantismo de sua época ${ }^{56}$ que, de tanto associar imagens e emoções à música, terminava por propor mais um devaneio que uma audição como experiência estética para os ouvintes. Grande paladino dessa reação purista, Beethoven adverte aos ouvintes de sua Sinfonia Pastoral, predispostos a ouvir passarinhos, trovões e tempestades, que se trata de mehr Ausdruck der Empfindung als Mahlerey (mais expressão do sentimento que pintura ${ }^{57}$ ) e, em outras ocasiões, que a música deve ser ouvida de maneira a "incendiar o espírito de um homem, e não vertê-lo em lágrimas de um emocionalismo barato" ${ }^{\text {"58 }}$.

Ficam assim lançadas as bases para um estudo da dimensão semântica do nível profundo e de suas implicações na economia do percurso gerativo no que

\footnotetext{
${ }^{55}$ Salzer, 1962, Vol. I:14.

${ }^{56}$ Segunda metade do século XIX.

${ }^{57}$ T.1.a.

${ }^{58}$ Beethoven, 1978:226 (t.1.a.).
} 
tange à foria e à tensividade. Antes de partirmos definitivamente para o estudo do nível narrativo, há ainda que se abordar uma terceira perspectiva da semântica fundamental: a aspectualização. Sendo as modulações, nas palavras de Greimas e Fontanille, nada mais que "uma prefiguração da aspectualização discursiva ${ }^{59}$ ", serão igualmente tratadas no mesmo tópico.

\section{a) Aspectualizações e modulações}

As gradações de direcionalidade e de intensidade do fluxo do devir constituem aquilo que denominamos modulações do devir. Em sua própria essência, trata-se de um fenômeno indissociável do conceito de aspectualização tanto no que concerne à quantificação intrínseca à sua variação de intensidade quanto à sua qualificação, como nos propõe Greimas, segundo os aspectos incoatividade ou abertura, cursividade, terminatividade ou fechamento e pontualidade. Apesar do notável adiantamento da atual pesquisa semiótica no que tange ao nível narrativo em geral e ao estudo do equacionamento modal das paixões em particular, a investigação do papel das modulações na geração dos estados patêmicos tem sido deixado relativamente de lado, aparentemente sem grande prejuízo ao menos no que concerne à análise do discurso verbal. A eventual dificuldade em identificar com precisão o caráter das modulações é comumente contornada através da postulação de sua existência, reconhecendo-se a posteriore suas manifestações no discurso. De fato, recomenda-nos a Semiótica das paixões buscá-las exatamente nas aspectualizações que as convocam ao nível discursivo, numa materialização que operacionaliza sobremaneira o modelo teórico. No caso da semiótica musical, dadas a clareza com que se evidenciam as modulações do devir sob a forma de aspectualizações discursivas e a aparente impossibilidade de uma detecção direta das modalidades, o que obriga o analista a postular sua existência e a recuperar sua ação num ponto posterior da análise, cria-se uma situação inversa àquela que se apresenta ao semioticista quando da análise de um texto verbal. As próprias características do código musical repercutem numa clara representação no nível discursivo das sutis transformações do fluxo protensivo, elevando o estudo das modulações ao patamar de alicerce da pesquisa semântica dentro da investigação do sentido na música, sobretudo no que tange à análise dos efeitos de sentido passional, ou seja, à semântica narrativa de um texto musical. Em função disso, o estudo das paixões na música apresentado neste trabalho deve seus fundamentos quase que inteiramente à análise das modulações do devir, suas discretizações e consequientes conversões ao nível narrativo, conforme será apresentado em item posterior. Ateremo-nos no momento à identificação e reconhecimento das modulações do devir em exemplos musicais, sempre através de suas convocações a partir de aspectualizações discursivas, o que nos fornecerá em contrapartida subsídios para um estudo dos principais processos pelos quais as gradações do fluxo tensivo-fórico sensibilizam a figura do observador, inaugurando a dimensão aspectual do discurso e investigando seu papel no percurso gerativo do sentido.

Consideremos inicialmente a Abertura da Suíte Aus Holberg's Zeit, de Edvard Grieg. Procuremos identificar na partitura abaixo os principais movimentos das modulações do devir através de suas aspectualizações discursivas.

\footnotetext{
${ }^{59}$ Greimas \& Fontanille, 1993:30.
} 

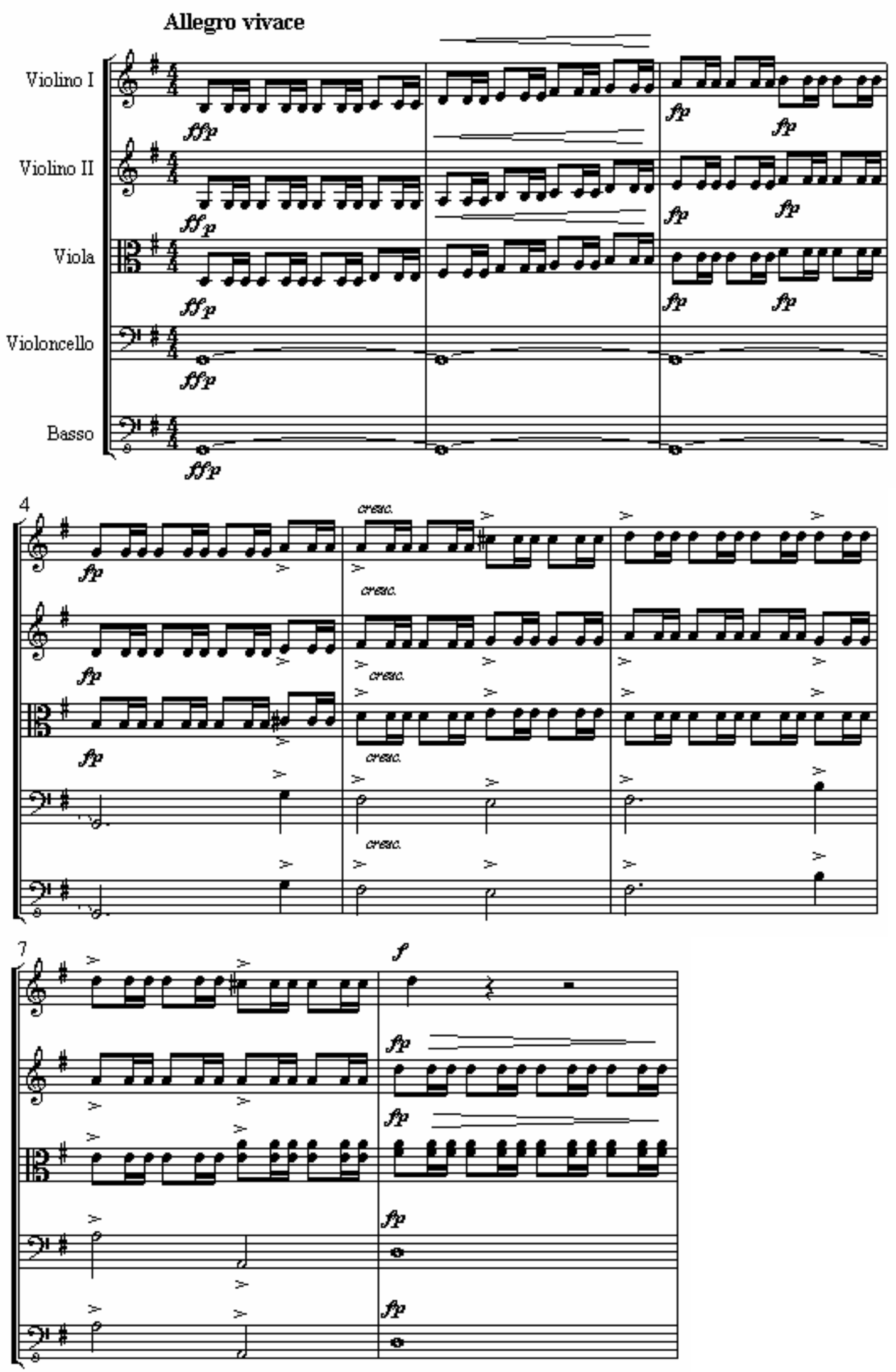

O movimento melódico ascendente que se verifica até o compasso 6 define uma clara direcionalidade rumo à abertura, que por sinal pode-se observar 
também na dinâmica basicamente crescente (apesar das acentuações, que merecem tratamento separado) do piano ao forte. Ainda que de maneira bastante secundária, vale ainda chamar a atenção para a pontualidade causada pela incidência dos fortepiano e para a cursividade advinda da continuidade de contornos melódicos e dinâmicos do texto, discursivizados enquanto abertura melódica crescente e pelo crescendo que conduz do piano inicial ao forte final. A cursividade, nesse caso, aproxima-se conceitualmente de uma continuidade do fluxo do devir representada não tanto por aquilo que a física matemática chama de movimento retilíneo uniforme, com sua velocidade constante, mas por aquele conhecido como movimento retilíneo uniformemente variado, que varia a partir de uma aceleração constante. Vale lembrar que o primeiro é na realidade um caso especial do segundo, onde o módulo da aceleração é igual a zero. Tal abordagem da cursividade no discurso musical permite uma melhor compreensão dos efeitos de sentido dela decorrentes, conforme será visto em item posterior, quando se analisará sua conversão ao nível narrativo, gerando a modalidade do poder. De fato, pode-se desde já avaliar que a "inflação" de um sujeito em seu modo de existência parece bastante compatível com um percurso de atualização, e que já verificamos anteriormente que, atingido um limite tensivo de intensificação, segue-se uma mudança de estado, o que equivale a uma transição rumo à realização.

Pudemos observar a partir do breve segmento analisado que o quadro modulatório de um texto musical tende a uma certa complexidade, onde vários aspectos se somam, havendo entretanto freqüentemente a predominância de um em detrimento dos demais. Dessa forma, cabe ao analista um grande cuidado ao selecionar e hierarquizar os aspectos presentes, de forma a permitir uma visão dos principais elementos discursivos que assumirão papel proeminente na economia do percurso gerativo sem entretanto incorrer numa simplificação excessiva do quadro modulatório, o que induziria simplesmente a um empobrecimento da análise e a um reducionismo que resultaria em sérios prejuízos no momento de se tratar a configuração patêmica do texto, ou seja, sua semântica narrativa.

Prossigamos agora tomando como exemplo a Introdução do I Movimento da Serenata para Cordas, de Tchaikovski. Atentemos novamente para os contornos melódico e dinâmico do trecho em questão, e procuremos assim visualizar seus principais movimentos modulatórios a partir de suas aspectualizações discursivas.

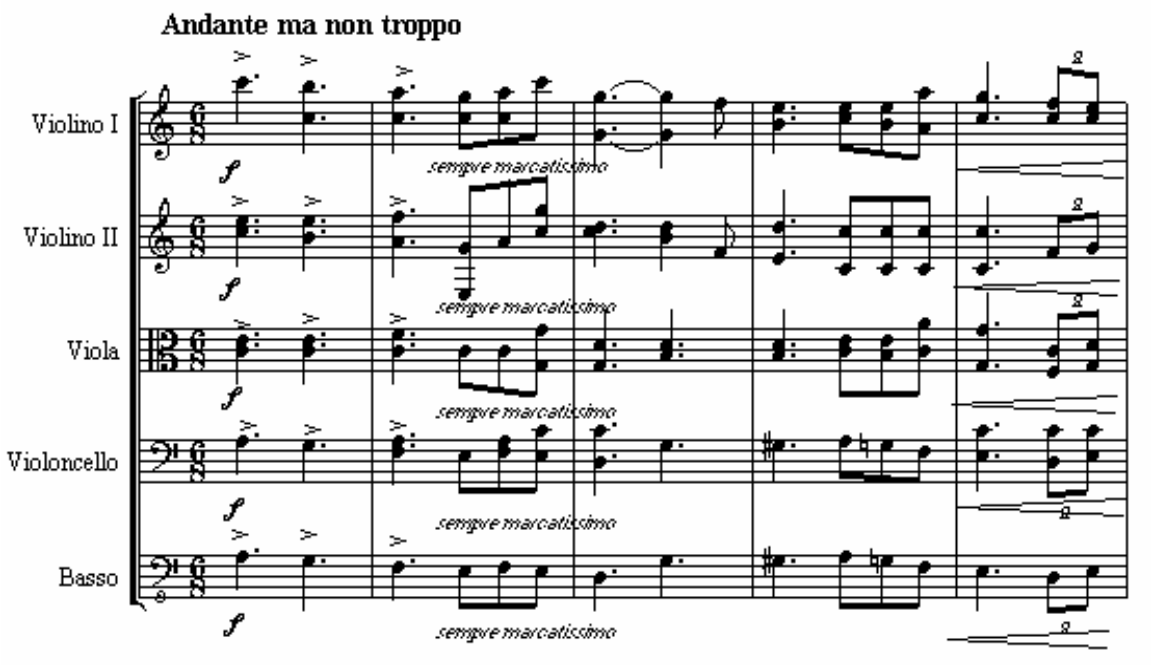




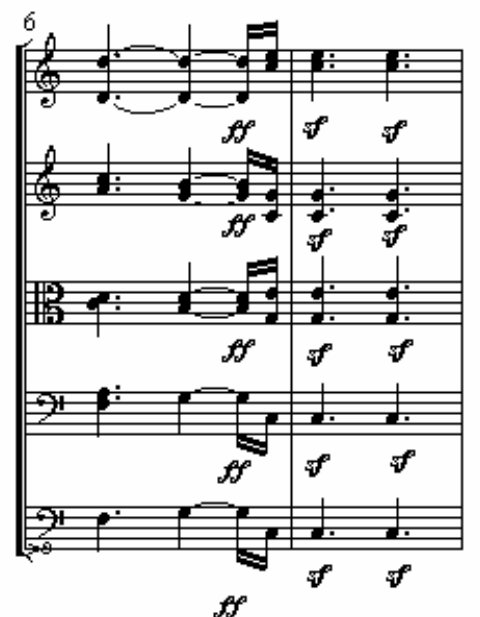

Iniciemos nossa apreciação por uma avaliação do encaminhamento melódico do segmento. Na figura abaixo, estão identificados os intervalos que compõe sua linha melódica.

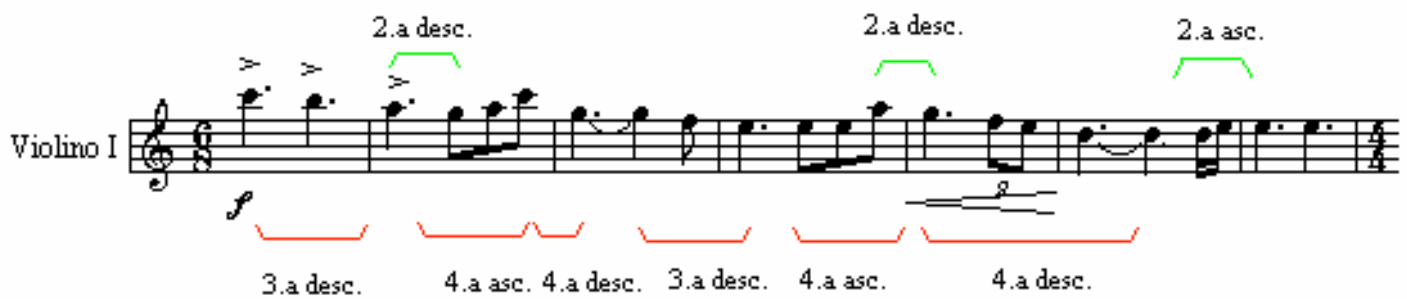

O que observamos é uma predominância dos intervalos de 3.a e 4.a, resultando numa disposição geral claramente descendente. Observe-se que cada 4.a ascendente é imediatamente compensada por uma 4.a descendente, resultando numa movimentação que pode ser esquematizada pelo diagrama:
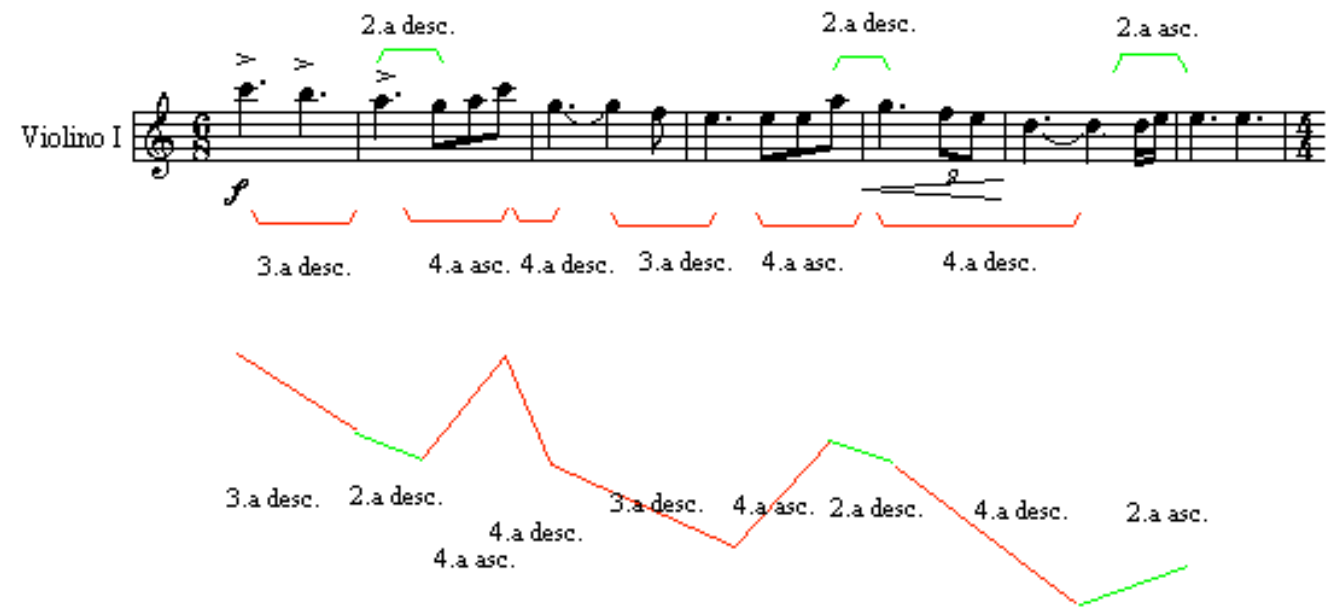


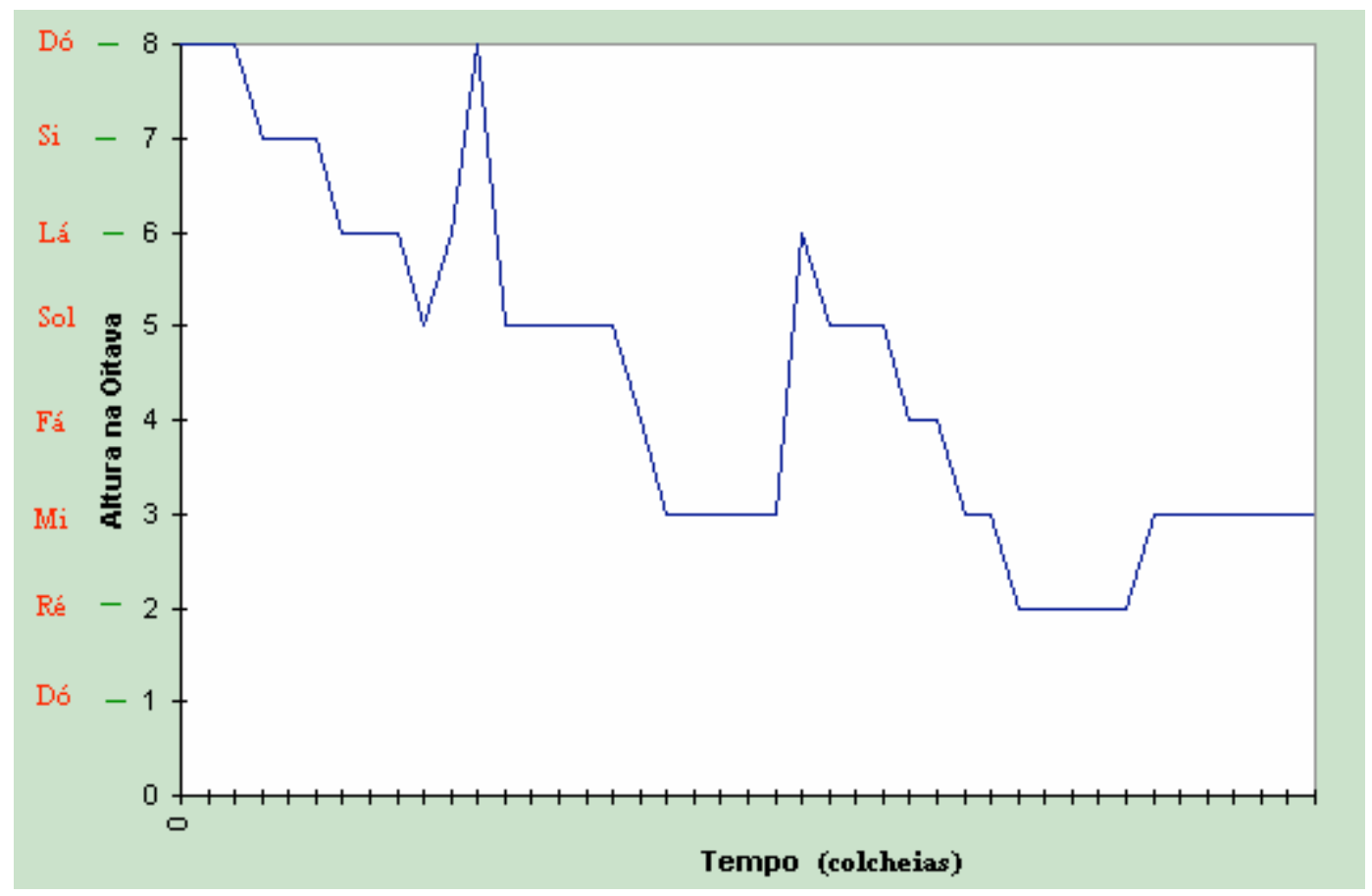

Tal descendência melódica delineia-se como gesto de fechamento, constituindo em última análise uma aspectualização terminativa, contribuindo com um componente assertivo para o correspondente semântico no plano do conteúdo.

Examinemos agora aspectos da dimensão rítmica do segmento. A célula básica consiste simplesmente em três batidas espaçadas em intervalos regulares. Esse material é em seguida condensado, gerando um efeito de aceleração, ou expandido, resultando em desaceleração. A aceleração, por provocar um efeito de direcionamento e focalização das modulações tensivo-fóricas, associa-se à incoatividade/abertura tal como concebida por Greimas/Fontanille na Semiótica das paixões. Pode-se compreender semioticamente tal fenômeno a partir de que se tenha em mente que a intensão da dimensão temporal do discurso conduz à sua discretização e polarização, conferindo uma virtualização ao modo de existência que lhe corresponde. Já a desaceleração remete a uma distensão e diluição da temporalidade responsável por uma tendência a retornar ao continuum da pré-significação, num gesto simétrico àquele que acabamos de analisar, e que analogamente se pode definir como terminatividade, e portanto, como resolução e fechamento das modulações tensivas. Assim sendo, verifiquemos agora os aspectos de abertura e fechamento associados ao segmento em questão no que tange à sua temporalidade. 


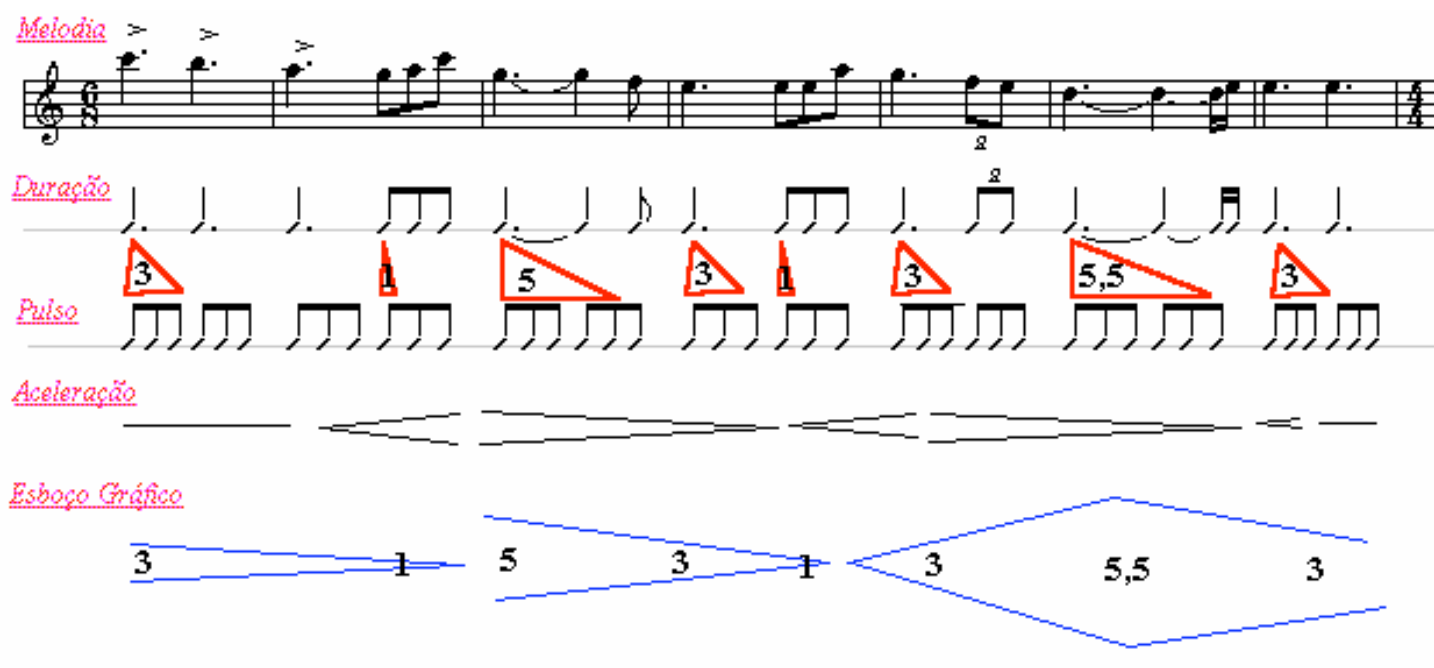

Na linha da Duração, pode-se ver a figuração rítmica correspondente à melodia, suprimida a barra de compasso para melhor visualização. A linha $\underline{P u l s o}$ facilita a verificação visual das durações, permitindo a identificação das variações de duração do beat ternário discutido anteriormente. Observa-se assim uma pulsação da temporalidade, contraindo-se e expandindo-se alternadamente, determinando a alternância de acelerações e desacelerações que entretanto se define em última análise como movimento de expansão silábica da temporalidade, levando-a a uma diluição que, tal qual vimos, corresponde a uma aspectualização terminativa e a um fechamento das modulações tensivo-fóricas.

Analisados os aspectos modulatórios nas dimensões melódica e temporal do discurso musical, passemos agora a uma análise dos mesmos na dimensão harmônica. A harmonia na música, como já exposto anteriormente, é talvez uma das manifestações lingüísticas que mais fielmente correspondem a uma convocação direta da própria tensividade ao nível discursivo, especialmente em textos que utilizam a linguagem tonal, para a qual Schoenberg nos muniu de um considerável instrumental teórico e analítico. Já observamos e discutimos também, ainda que brevemente, as relações entre limites tensivos e transformações de estado, o que nos possibilitará um instrumental valioso e relativamente inexplorado para o estudo da conversão do nível profundo ao narrativo no próximo capítulo deste trabalho. Passemos pois a uma análise dos aspectos modulatórios consequientes da instância harmônica do discurso.

Fazendo a redução da partitura de modo a facilitar a visualização da harmonia, procede-se à análise harmônica propriamente dita, realizada segundo suas duas principais abordagens, a tradicional e a funcional: 


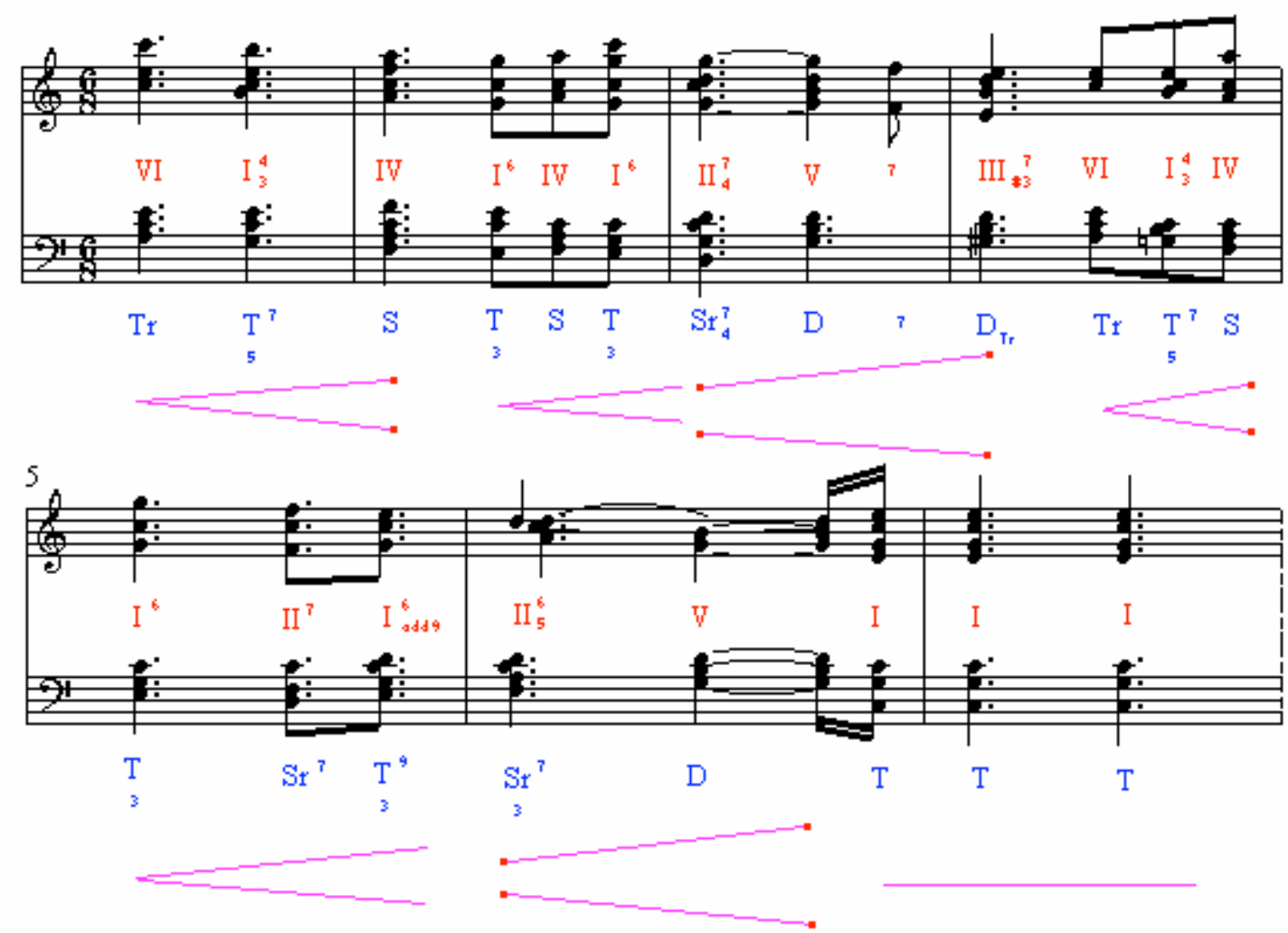

Conforme pode-se verificar pelo diagrama (onde os pontos a serem discutidos estão salientados por pequenos quadrados), a primeira apresentação da célula rítmica fundamental se insere num contexto harmônico de tensão crescente, contrastando com sua sequiência em colcheias, que mostra um nível de tensão inferior. Note-se que o acorde de subdominante (S) se fez acompanhar por uma mudança tanto de direcionamento melódico quanto de densidade temporal, apontando as mudanças de estado como consequiência de seu nível de tensão harmônica. A progressão seguinte apresenta também nível ascendente de tensão harmônica, chegando ao clímax tensivo do segmento no acorde de dominante da tônica relativa $\left(D_{T_{r}}\right)$. Ao clímax, segue-se paralelamente nova transformação de direcionamento melódico e nova alteração rítmica, com o retorno da figuração de colcheia. Atingido mais uma vez o grau de tensão correspondente à subdominante, as mudanças melódicas e temporais já citadas voltam a ocorrer, começando uma intensificação tensiva que atinge um degrau no acorde de subdominante relativa $(\mathrm{Sr})$ culminando com a dominante (D), após a qual chega-se finalmente ao relaxamento com os três acordes de tônica $(\mathrm{T})$. Tal relaxamento apresenta por si só a terminatividade já observada nas outras instâncias do discurso musical, se bem que o comportamento harmônico tenha evidentemente uma relação muito mais imediata com a tensividade do que com qualquer aspecto modulatório visto até o momento. Assim, a identificação de incoatividade, cursividade, pontualidade e terminatividade na instância harmônica faz-se de importância em geral secundária em relação ao comportamento tensivo que ela discursiviza com grande nitidez. Observe-se por último com que clareza se relacionam nível tensivo e transformação de estado, e de que maneira as diferentes instâncias do discurso musical se organizam num todo coerente mas não redundante, revelando 
como a diversidade de meios e os ritmos pulsatórios distintos se harmonizam em construções de sentido ricas e complexas.

Consideremos por último a instância dinâmica, ou seja, o comportamento das intensidades no trecho musical em questão.

$\mathrm{Na}$ partitura, lêem-se as indicações de $\boldsymbol{f}$ (forte) combinando com acentos (>), resultando na articulação em seguida explicitada no comentário sempre marcatissimo. Um crescendo se inicia logo antes do acorde de subdominante relativa (Sr), que vai até um $\boldsymbol{f f}$ (fortíssimo) seguido por dois sforzati. Tendo-se em mente as categorias exagerado $\mathbf{x}$ insuficiente, trata-se claramente de um caso de aspectualização por excesso, o que, na instância subjetiva, implicaria um sujeito exagerado, tal como se verifica freqüentemente na figura literária do herói, e associável ao caráter majéstico e imponente que diversos críticos observam na peça de Tchaikovski. O crescendo final simplesmente sublinha o tensionamento harmônico dos compassos 5 e 6 , e os sforzati que lhe seguem grifam a terminatividade do compasso 7. Nesse caso específico, portanto, muitas das informações colhidas a partir da dinâmica marcada na partitura tornam-se redundantes caso tenha sido feita uma análise das demais instâncias do discurso musical.

Tendo os exemplos analisados até agora fornecido subsídios para o estudo e identificação tanto das modulações do devir convocadas ao discurso musical, quanto das aspectualizações tensivas, faremos no próximo item um breve balanço sob o prisma semiótico das possibilidades da linha de investigação apresentada até o momento. Antes disso, porém, cabe um comentário a respeito da omissão intencional no presente tópico de um mergulho na dimensão fórica do discurso. Tal se deve por duas razões básicas. A primeira é que isso não se fez, em absoluto, necessário para a investigação desenvolvida até agora. A segunda é que procurar antecipar uma especulação a esse respeito nesse ponto do trabalho implicaria uma simplificação excessiva do universo semântico do texto, a já citada advertência de Hanslick, resultando apenas numa tentativa de enquadrar determinados elementos do discurso no modelo do eixo categórico euforia $\mathbf{x}$ disforia, num procedimento em que, ao invés de se utilizar o modelo para compreender o processo de geração de sentido do texto ou o texto para se refletir a respeito do modelo (e, se possível, revê-lo e ampliá-lo), tentar-se-ia simplesmente adequar o texto ao modelo analítico, com resultados pouco enriquecedores para nossa investigação. Em vez disso, uma avaliação das conversões e convocações da foria no discurso será sim apresentada, mas apenas onde sua consideração se torna absolutamente inadiável, ou seja: no tópico a respeito da semântica narrativa, o estudo das paixões no texto musical. Evita-se assim ao máximo o risco do subjetivismo, robustecendo o modelo de análise sem colocar em risco as conquistas realizadas até o momento e sem fugir de fato a essa questão. Finalizemos, pois, nossa discussão a respeito do nível profundo com algumas colocações a respeito das modulações e aspectualizações e suas projeções no discurso.

\section{b. Da convocação ao nível discursivo}

Se o modelo de investigação do percurso de geração de sentido de Greimas tem-se mostrado robusto o suficiente para não se limitar a textos verbais, é exatamente pelo fato de dispor de uma base conceitual tão bem estruturada que lhe permite flexibilizar seu instrumental metodológico ante o objeto de análise sem prejuízo da integridade do modelo. Deixando momentaneamente de lado a experiência 
de Floch e de seus seguidores no desenvolvimento de uma semiótica visual baseada no pensamento greimasiano, atenhamo-nos ao caso isolado de adaptar sua abordagem metodológica, criada e aplicada inicialmente dentro da problemática da verbalidade, para funcionar com igual eficácia em textos de natureza musical. Poder-se-ia pensar, num primeiro momento, que diferenças significativas apenas surgiriam quando do estudo do plano discursivo. O lingüista lituano, entretanto, já prevê que, mesmo enquanto simulacro, a abordagem de seu modelo está fundado menos no estabelecimento de três patamares do que na intensa permeabilidade pela qual o fluxo do sentido percorre cada um deles, criando uma complexa rede de interrelações sintáticas e semânticas. Neste capítulo, em que discutimos a semântica do nível profundo, ao mergulharmos nas questões relacionadas à aspectualização, modulação e tensividade, vimo-nos naturalmente, pela própria natureza do processo aspectual, arremessados ao nível discursivo, obrigando-nos a fundamentar toda nossa análise a partir de observações realizadas a partir da superfície do discurso. Nessa primeira interface entre plano de expressão e plano do conteúdo, confirmou-se a concepção de sistema semi-simbólico como aquela que melhor dá conta do processo de geração de sentido em um texto dessa natureza, onde, havendo linguagem, não há entretanto codificação comparável àquela existente no campo verbal, que estabelece relações de correspondência biunívoca entre signo e elemento do mundo natural. Assim, partindo, por assim dizer, da gestualidade do discurso é que pudemos captar os elementos necessários a uma investigação de seu percurso gerativo. Tratamos, até o momento, de rastrear esse percurso a partir da projeção imediata no plano do conteúdo de elementos aparentemente do plano de expressão, quais sejam: melodia, ritmo, harmonia e intensidade (as questões relativas ao timbre, por envolverem freqüentemente uma discussão a respeito de intertextualidade, estão além dos objetivos deste trabalho; naturalmente, todos os exemplos ilustrativos foram escolhidos entre obras em que a orquestração desempenha um papel menor no processo de geração de sentido). Refletindo um pouco a esse respeito, percebemos contudo que os quatro conceitos expostos acima já pertencem na verdade ao plano do conteúdo, pois o próprio processo de abstração que permite neles decompor o plano de expressão já envolve uma intelecção sintática e semântica do texto, ainda que, naturalmente, de natureza distinta daquela que vivenciamos comumente diante de um texto literário.

No decorrer da análise, ficou patente que, enquanto as instâncias melódica e rítmica do discurso apresentam com especial nitidez aspectualizações modulatórias, as instâncias harmônica e dinâmica mostram a mesma vocação de transparência com relação aos aspectos tensivos. Vislumbrou-se também como se harmonizam as diferentes instâncias discursivas num todo coerente mas não redundante, complexo mas ordenado. No entanto, fica logo evidente que, ao nos propormos a um estudo detalhado do nível profundo, passamos necessariamente a um mapeamento do nível discursivo que, se não chega a esgotá-lo, é suficientemente aprofundado para revelar alguns dos principais elementos necessários à pesquisa semiótica do nível de superfície, especialmente no que tange à sua relação com os demais patamares de significação. Assim, o reconhecimento dos aspectos nas modulações nos fornece subsídios para propor uma semântica narrativa a partir da pressuposição de uma instância discretizadora que permita a conversão das modulações em modalidades e, a partir daí, utilizar o equacionamento modal proposto por Greimas e Fontanille para um estudo da paixão no discurso musical. Por outro lado, conforme enfatizado no item anterior, existe claramente, para cada contexto, um 
limite de intensão a partir do qual ocorre uma transformação sintática na estrutura do discurso que se consuma em uma mudança de estado de coisas ou de alma, acarretando uma reorganização das relações juntivas entre os sujeitos e os valores do sistema. Assim, é a própria sintaxe narrativa quem também se esboça ao passo que mergulhamos num estudo a respeito da tensividade.

Começa a se delinear assim uma metodologia de abordagem semiótica do texto musical onde a pesquisa do nível profundo se inicia sob o ponto de vista sintático a partir da identificação das projeções no discurso da oposição intensão $\mathbf{x}$ extensão e sob o ponto de vista semântico a partir da detecção das convocações da tensividade-foria ao nível discursivo através das aspectualizações modulatórias e tensivas. Assim, uma vez estudada a ação dos processos de convocação, encontramonos naturalmente já mergulhados na investigação das transformações de estado que compõem em última análise a estrutura narrativa do discurso tanto sob o prisma semântico quanto sintático, fechando-se dessa maneira o círculo que nos permite uma compreensão do percurso gerativo de sentido como um todo orgânico, respeitada a peculiaridade e especificidade do código utilizado pelo texto. 


\title{
2.3. Do nível narrativo
}

\subsubsection{Sintaxe narrativa: das transformações de estado ao fluxo de valores}

\begin{abstract}
¿Es una ilusión la unidad que apreciamos en una obra de arte? ¿Es sólo una hipótesis crítica? Si es verdad que tiene una entidad, la descripción de su forma no puede limitarse a enumerar los elementos que la componem, sino que ha de decirnos por qué constituye un todo ${ }^{60}$.
\end{abstract}

\section{Charles Rosen}

A teoria musical no ocidente, ao debruçar-se e refletir sobre seu imenso e formidável repertório, concluiu, a partir principalmente das obras de Riemann e Schenker, que cada composição é derivada de um motivo básico breve (Rosen, 1986:44). Cada um desses estudiosos, criando sua própria metodologia, foi capaz de dotar a teoria musical de subsídios que lhe permitiram chegar a constatar que algumas obras de longa duração, através de engenhosos recursos composicionais, representavam a transformação contínua de uma única célula musical básica. Entretanto, apesar de que a teoria se mostra hoje capaz de identificar e reconhecer as transformações do material musical ao longo do discurso, e mesmo, como quer o modelo schenkeriano, afirmar e garantir a unidade do texto desde que haja um tipo específico de analogia entre os modelos que ele propõe para a macro e a microestrutura da composição, há que se admitir que a teoria musical é ainda fundamentalmente taxinômica. Ela de fato constata, identifica, rotula e classifica as transformações de estado. Mas ela não propõe nenhuma explicação a respeito do como e do por que tais transformações ocorrem.

A teoria semiótica desenvolveu um modelo pelo qual toda transformação de estado em um discurso pode ser compreendida em última análise enquanto alteração no estado juntivo de um sujeito com um dado valor do sistema. A prática do equacionamento de tais transformações evidenciou a importância das relações intersubjetivas, onde um sujeito atua sobre outro sujeito alterando seu estado juntivo, criando-se em função disso o conceito de destinador. Também os valores, sob as lentes da análise, se fizeram distingüir entre valores modais, que alteram a relação entre o sujeito e os demais valores do discurso, e valores descritivos, limitados em sua atuação a sua própria aquisição ou privação por parte do sujeito. Assim, a semiótica apresenta um como a transformação de estado ocorreu, identificando quais os valores e sujeitos nela implicados, e um por que, ao situar o programa narrativo dentro de um percurso e reconhecer qual ou quais valores do discurso se apresentam com um estatuto modal hierarquicamente superior, regendo e organizando os demais e determinando o próprio modo de existência do sujeito.

É precisamente no estudo da organização narrativa do texto musical que o modelo greimasiano e a teoria musical como um todo apresentam maior grau de complementaridade, possibilitando assim um intercâmbio conceitual e empírico capaz

\footnotetext{
${ }^{60}$ Rosen, $1986: 44$
} 
de beneficiar ambas as epistemes, fornecendo à primeira um amplo repertório de soluções empíricas a analisar, utilizar e questionar e, à segunda, um considerável aprofundamento e robustecimento do atual modelo teórico, viabilizando o preenchimento das várias lacunas apontadas por críticos e estudiosos (Rosen, 1986:44; Tarasti, 1996:17). Para ilustrar essas colocações, examinemos o trecho inicial da Fuga I do Cravo bem temperado, de J.S. Bach:

\section{Fuga I
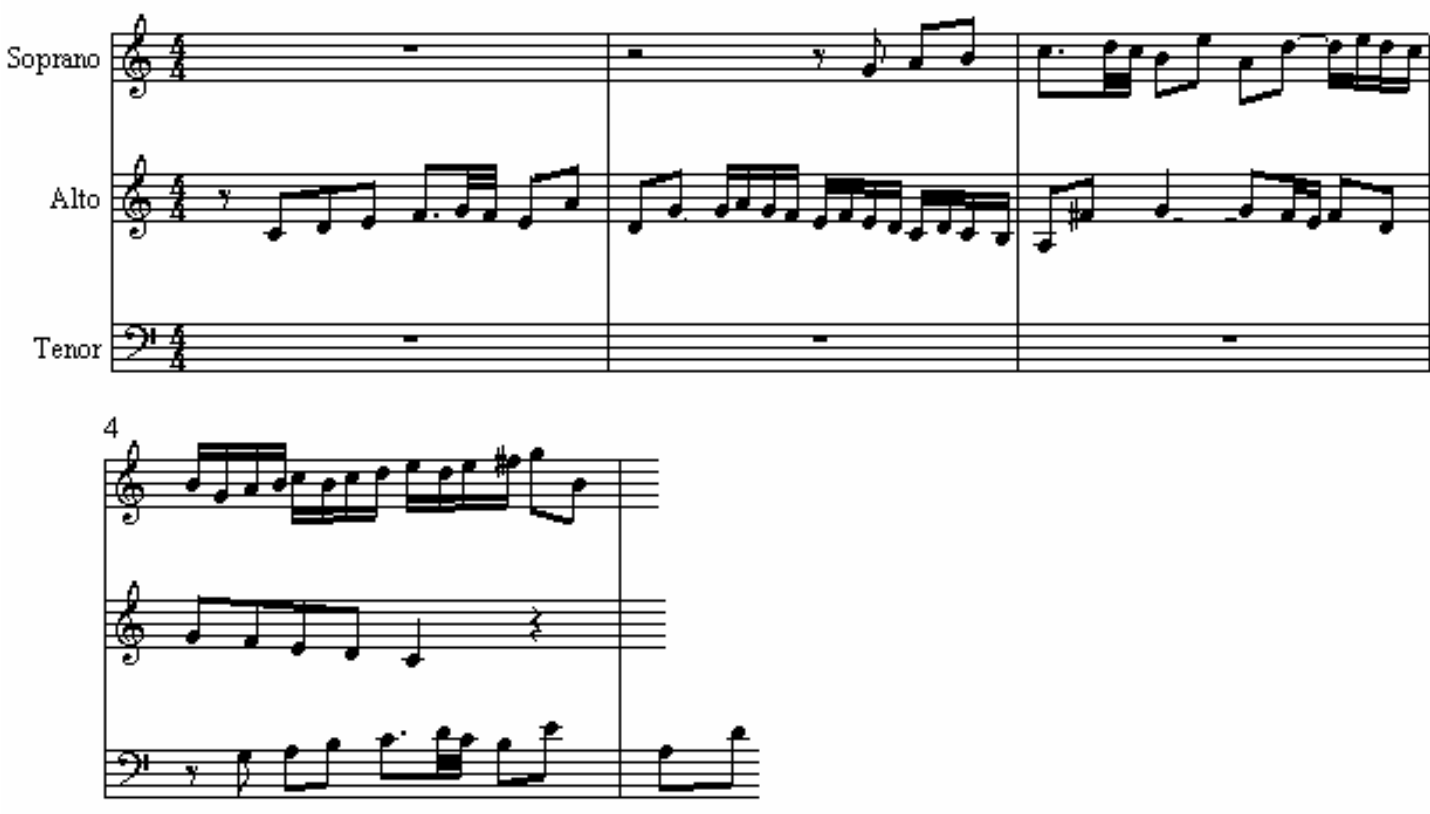

A teoria musical tradicional reconhece esse trecho inicial como parte da exposição $^{61}$ de uma fuga. Toda fuga é construída sobre um sujeito, que é apresentado inicialmente numa dada voz (no caso presente, em contralto ou alto), sendo em seguida reapresentado com algumas modificações nas demais vozes, recebendo o nome de resposta a cada vez em que é apresentado em altura diferente (geralmente distando um intervalo de 5.a ascendente ou descendente daquela original). Também parte essencial da fuga é o contrassujeito, que constitui um contraponto que acompanha o sujeito/resposta. Além de outras sessões fundamentais à estrutura da fuga que não aparecem aqui devido à brevidade do trecho citado, como o divertimento, o stretto, o pedal e a coda, temos aqui ainda um exemplo de parte livre, que, como o nome indica, não segue nenhuma configuração básica preestabelecida. Identifiquemos agora, então, os termos especificados.

\footnotetext{
${ }^{61}$ A terminologia musical será apresentada em negrito de modo a distingüi-la de seus termos homônimos na teoria semiótica.
} 

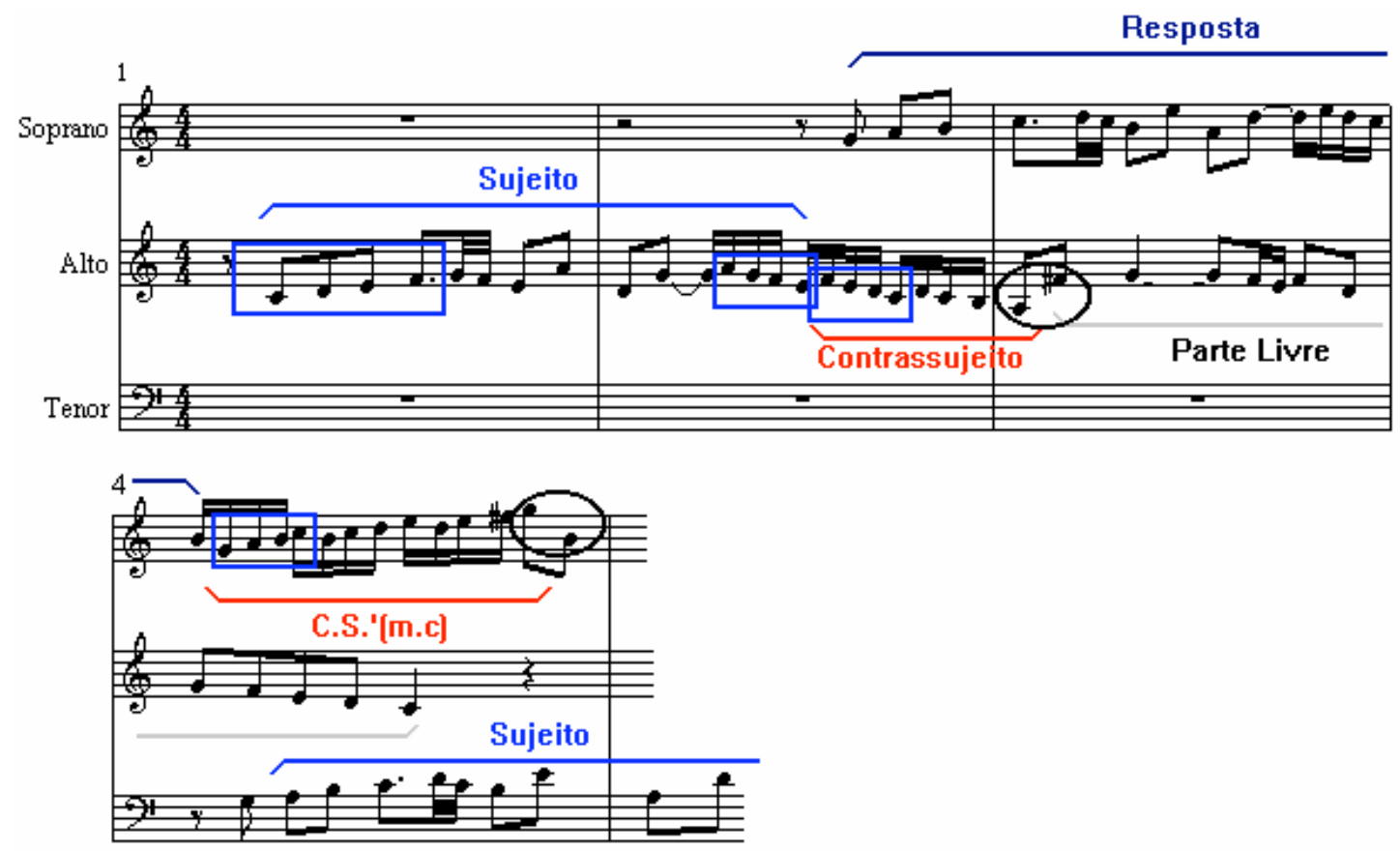

Fora o reconhecimento dos componentes discursivos denominados sujeito, contrassujeito, resposta e parte livre, a teoria musical tradicional tem elementos ainda para reconhecer algumas outras relações, além daquela naturalmente implicada entre sujeito e resposta. A principal delas é a constatação da presença de um motivo comum na composição tanto do sujeito (e, conseqüentemente, das respostas) quanto do contrassujeito, estando esse material assinalado na figura acima por um retângulo. Assim, o motivo:

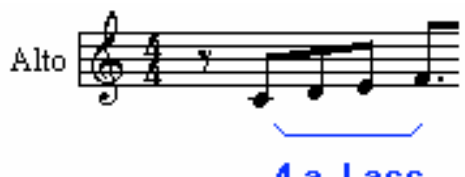

constituído sobre um intervalo escalar ascendente de 4.a justa, gera por movimento contrário (retrogradação), transposição e diminuição (contração temporal) o motivo final do sujeito, que por sua vez é o mesmo material de todo o contrassujeito:

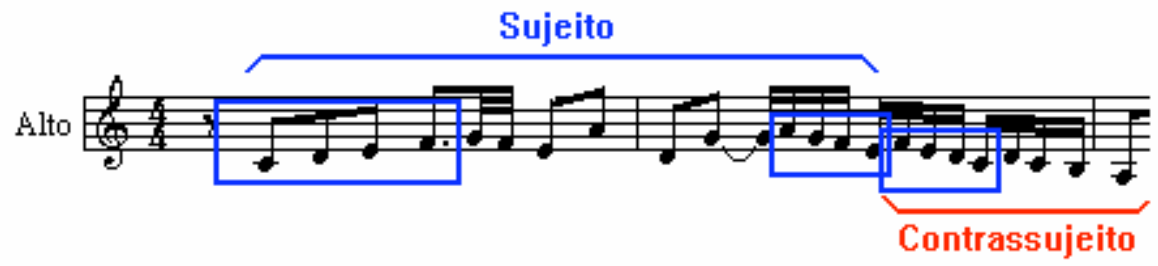

Vejamos uma descrição um pouco mais pormenorizada do percurso que transforma o material inicial naqueles outros descritos acima, ainda limitando-nos aos cânones tradicionais da teoria musical: 


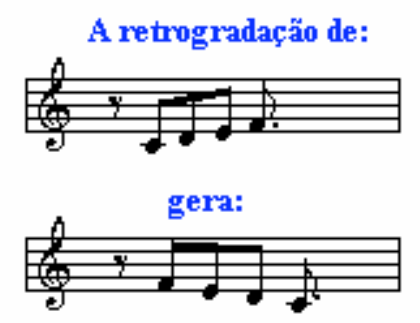

Por diminuição, as colcheias contraem-se para semicolcheias:

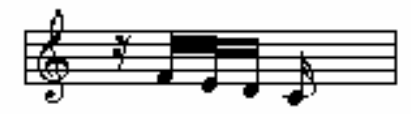

gerando a primeira célula do contrasujeito:

Detalhe:
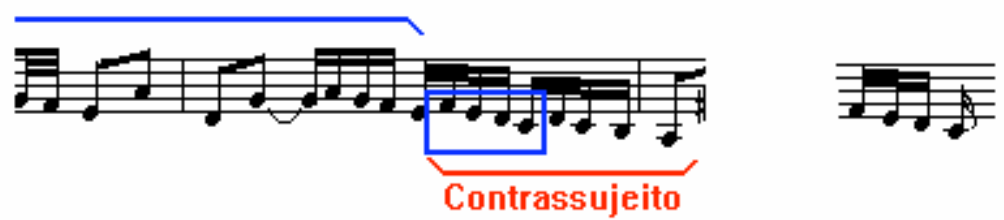

e,por transposição, a última do sujeito (e demais do contrasujeito) : Sujeito

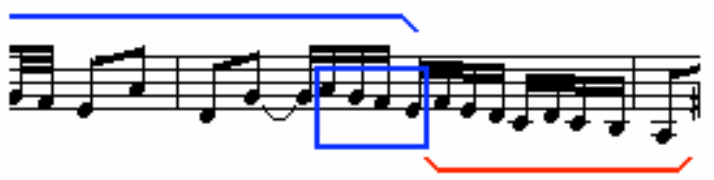

Detalhe:

Vamos agora interromper momentaneamente nossa análise musical visando propor uma visão semiótica das transformações de estado em questão. Para isso, vamos desde já nos valer da metodologia desenvolvida até o presente ponto deste trabalho, tanto sob o ponto de vista musical quanto semiótico, o que implica um certo aprofundamento sem o qual não seria possível dar prosseguimento a nossa pesquisa.

Conforme exposto anteriormente, o primeiro passo para uma abordagem semiótica de um texto musical é identificar os mínimos elementos discursivos portadores por convocação das valências de intensão e extensão do sistema. Uma análise do sujeito da fuga nos fornece como configuração inicial o intervalo de 4.a justa ascendente enquanto portador dos valores de extensão, e o intervalo de 3.a menor descendente enquanto portador dos valores de intensão:

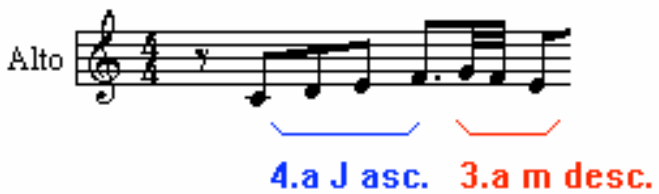

Tal se evidencia principalmente em função da instância temporal, quatro vezes mais concentrada no segundo elemento que no primeiro, indiciando assim sua intensividade. Passemos agora à verificação do desenvolvimento desses dois elementos ao longo do sujeito, a começar pelo primeiro. $O$ intervalo de 4.a ascendente aparece mais duas vezes, não mais decomposto escalarmente, mas sob a forma intensificada de um salto direto: 


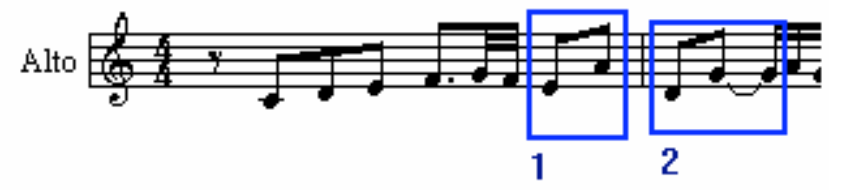

Observe-se que, sob o ponto de vista temporal, o intervalo assinalado em 1 é mais intenso não só do que o motivo original mas também do que aquele assinalado em $\mathbf{2}$. A evidente variação tensiva aspectualizada temporalmente remete a um percurso coberto ao longo do eixo das valências no nível profundo, cuja conversão origina os valores a serem intercambiados ao longo do discurso. No presente caso, o intervalo de 4.a, inicialmente portador dos valores de intensão do sistema, cobriu o seguinte percurso:

Estado 1: $\quad$ (4.a J) $\Lambda$ (valor extenso)

intensão

Estado 2: $\quad$ (4.a J) $\Lambda$ (valor intenso) extensão

Estado 3: $\quad$ (4.a J) $\Lambda$ (valor de distensão)

O percurso narrativo pressupõe etapas intermediárias entre os estados 1 e 2 (disjunção com o valor extenso/conjunção com o valor intenso, ou, simplesmente, intensão do valor) e entre os estados 2 e 3 (analogamente, extensão do valor). A melhor forma de suprirmos essas lacunas será passarmos agora ao estudo do segundo elemento: o intervalo de 3.a menor descendente. Conforme visto anteriormente, ele aparece inicialmente associado aos valores de intensão do sistema, marcados discursivamente por uma contração da temporalidade:

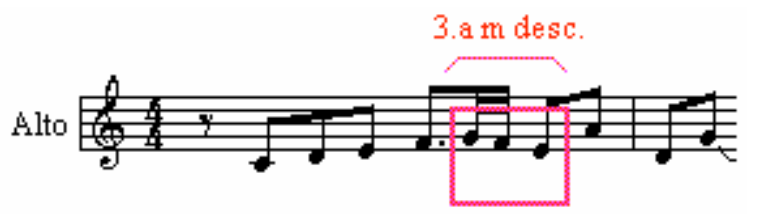

Há entretanto nesse segmento uma outra 3.a menor. Formada justamente pelas extremidades dos intervalos de 4.a, ela corresponde à resultante do movimento de translação do motivo principal provocado pela ação do intervalo de 3.a:

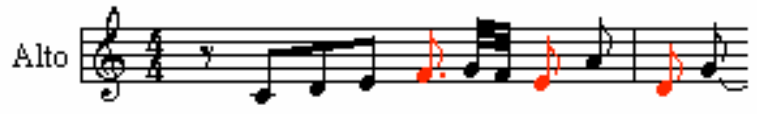

Ora, a 3.a com durações de semínima em: 


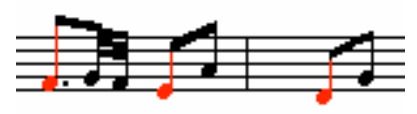

está oito vezes mais diluída temporalmente do que em sua primeira aparição. Podemos a partir disso constatar uma transformação onde o intervalo de 3.a, portando inicialmente valores intensos, passa a ser portador de valores extensos do sistema, gerando os seguintes enunciados de estado:

Estado A: $\quad$ (3.a m) $\Lambda$ (valor intenso)

extensão

Estado B: $\quad$ (3.a m) $\Lambda$ (valor extenso)

Assim como no caso anterior, pressupõe-se uma etapa intermediária em que ocorra a disjunção com o valor intenso. Ora, é flagrante a complementaridade entre os percursos 1-2 e A-B, ao qual se segue ainda o percurso 2-3. A partir disso, podemos compreender o percurso narrativo da seguinte maneira: um sujeito $S_{1}$ está em conjunção com os valores de extensão do sistema (Estado 1); ao defrontar-se com um anti-sujeito $\mathrm{S}_{2}$, portador dos valores de intensão (Estado $\mathrm{A}$ ), há um intercâmbio temporário de valores entre os dois sujeitos (Estados 2 e B), passando $\mathrm{S}_{1}$ a cumprir um percurso de retorno gradual rumo ao estado tensivo inicial., dissipando sua intensividade. Podemos ilustrar a primeira metade desse processo, salientando o intercâmbio de valores entre os sujeitos, através do diagrama:

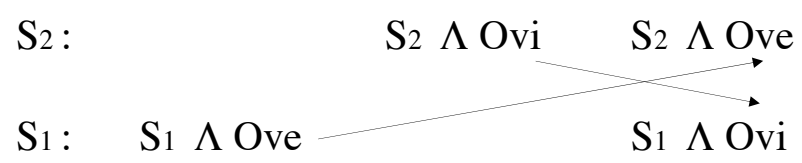

Cabe agora considerar mais um intervalo de 3.a, resultante das extremidades do penúltimo intervalo de 4.a (direto e ascendente) e do último (escalar e descendente):

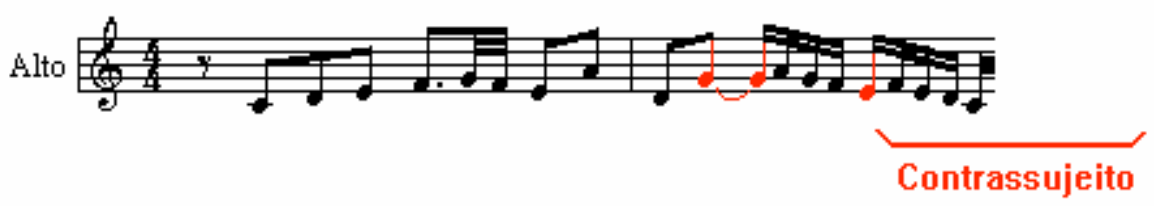

Esse intervalo, extenso por suas características temporais em relação a:

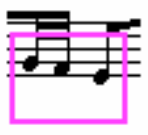

e intenso em relação a: 


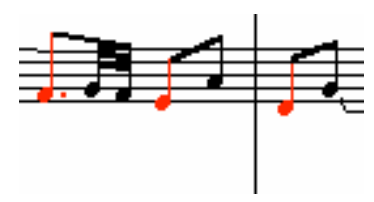

assinala uma intensificação dos valores a ele associados, o que nos fornece mais uma informação valiosa em relação à economia do sistema: paralelamente ao retorno à extensão em $\mathrm{S}_{1}$, há um retorno à intensão em $\mathrm{S}_{2}$. Assim, o diagrama de estado de $\mathrm{S}_{2}$ complementa-se da seguinte maneira:

Estado A: $\quad$ (3.a m) $\Lambda$ (valor intenso)

extensão

Estado B: $\quad$ (3.a m) $\Lambda$ (valor extenso)

$$
\text { intensão }
$$

Estado C: $\quad$ (3.a m) $\Lambda$ (valor intenso)

e, conseqüentemente, o intercâmbio de valores entre $S_{1}$ e $S_{2}$ assume as seguintes características:

Estado $1 \quad$ Estado A $\quad$ Estado 2/B Estado 3/C

$\begin{array}{llll}\mathrm{S}_{2}: & \mathrm{S}_{2} \Lambda \mathrm{Ovi} & \mathrm{S}_{2} \Lambda \mathrm{Ove} & \mathrm{S}_{2} \Lambda \mathrm{Ovi} \\ \mathrm{S}_{1}: & \mathrm{S}_{1} \Lambda \mathrm{Ove} \stackrel{\mathrm{S}_{1} \Lambda \mathrm{Ovi}}{\mathrm{S}_{1} \Lambda \mathrm{Ove}}\end{array}$

$\begin{array}{llll}\text { P1 } & \text { P2 } & \text { P3 } & \text { P4 }\end{array}$

determinando assim os pontos P1, P2, P3 e P4 do diagrama abaixo: 


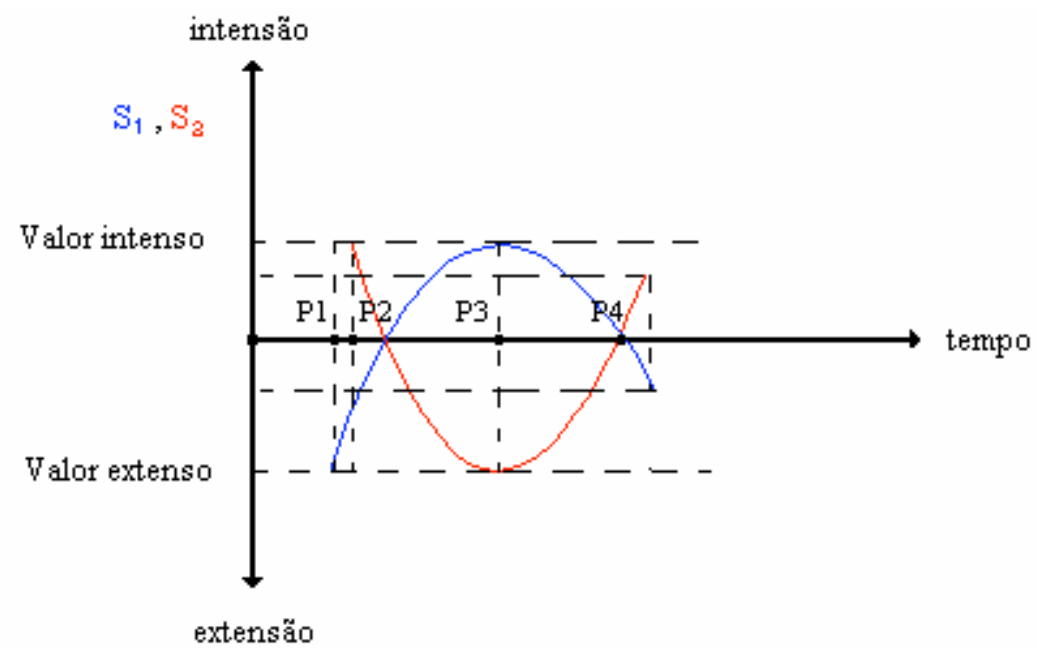

linha azul = trajetória dos valores em conjunção com $S_{1}$

linha vermelha $=$ trajetória dos valores em conjunção $\operatorname{com} \mathrm{S}_{3}$

O esquema acima nos permite visualizar o percurso narrativo do sujeito da fuga com clareza e fazer as seguintes observações:

a) Há dois sujeitos na narrativa: $S_{1}$, discursivizado pelo intervalo de 4.a e inicialmente portador dos valores de extensão; e $\mathrm{S}_{2}$, discursivizado pelo intervalo de $3 . \mathrm{a}$ e inicialmente portador dos valores de intensão;

b) A ação de $S_{2}$ sobre $S_{1}$ resulta no intercâmbio de valores entre os dois sujeitos, invertendo sua posição tensiva;

c) Há nesse trecho tipo de ascendência estrutural de $S_{1}$ sobre $S_{2}$ que se evidencia à medida que $S_{2}$ aparece sobretudo implicitamente na narrativa, ao passo que $S_{1}$ aparece explicitamente; por outro lado, a ação de $S_{2}$ sobre $S_{1}$ permite identificá-lo ora como destinador, conferindo a $S_{1}$ valores que transformam sua relação com os demais valores do sistema (discursivizados, por exemplo, enquanto altura e ritmo), ora como anti-sujeito, estabelecendo uma relação polêmica com $\mathrm{S}_{1}$ e sofrendo ele também programas de manipulação;

d) Em dois pontos no trecho citado há um considerável aumento de tensividade: na primeira ocorrência de $S_{2}$, em função de ser ele o próprio portador dos valores de intensão do sistema; e no final da segunda aparição de $S_{2}$, onde se consuma o intercâmbio de valores entre os dois sujeitos. A tensividade, nesse caso, discursivizase sobretudo pela suspensão rítmica (criando-se uma expectativa de continuidade) e pela instância harmônica, virtualizando-se um acorde de dominante em função do padrão melódico usado. Essa virtualização, à primeira vista estranha à medida que se trata de um trecho monofônico, e não polifônico, tem entretanto fortes fundamentos interdiscursivos no contexto da música tonal ocidental por ser basicamente toda ela uma música harmônica, ficando assim a harmonia implícita em trechos meramente melódicos como esse (sobretudo por se tratar de uma composição de Bach; tal observação se tornaria questionável num outro contexto estético, como por exemplo, 
num contexto não-europeu). Os acordes ocultos, por assim dizer, aparecem entre parênteses na figura abaixo:

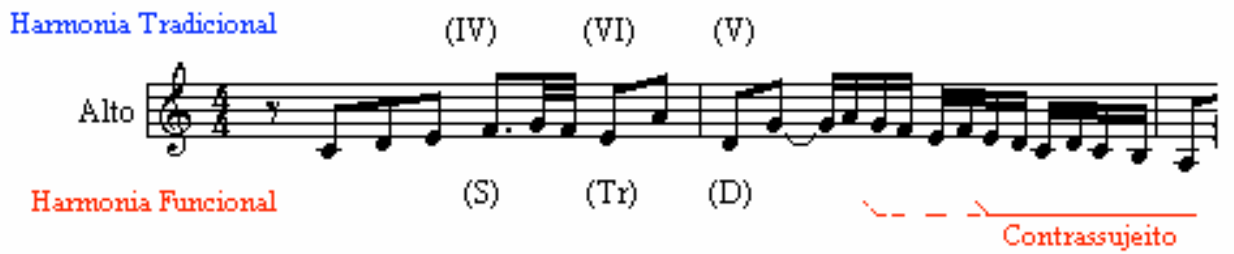

e) A cada um dos dois máximos tensivos associa-se uma transformação estrutural. A primeira se manifesta pela inversão do direcionamento melódico que, inicialmente ascendente, torna-se basicamente descendente, e pelo aparecimento do motivo resultante da contração temporal do intervalo de 4.a (colcheias ligadas). A segunda desencadeia a apresentação do motivo do contrassujeito, derivado de $S_{1}$ por contração temporal (diminuição é o termo que se usa em teoria musical) e por retrogradação, acentuando a descendência melódica e, em nível modulatório, a terminatividade do trecho. No diagrama abaixo, as transformações estão assinaladas como T1 e T2:

\section{FLUXO DE VALORES}

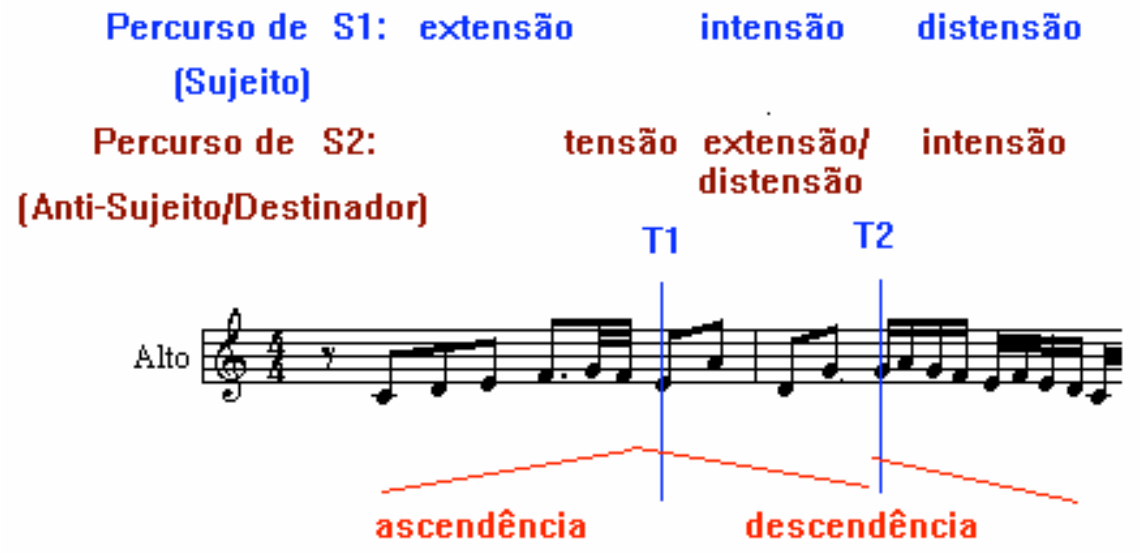

f) Após a inversão de valores, inicia-se um percurso de restauração do quadro econômico inicial; entretanto, o quadro tensivo do final do sujeito é fundamentalmente mais intenso que aquele de seu início. Note-se que o encerramento do intercâmbio de valores entre $S_{1}$ e $S_{2}$ em T2 corresponde ao final de um ciclo onde um movimento de pulsação apresentou sua sístole (T1) e sua diástole (T2), ocasionando pois um fechamento silábico que também, por si só, permite a introdução de um novo material correspondente à abertura da sílaba que se lhe segue.

g) Finalmente, vale ressaltar aqui um aspecto discursivo bastante pertinente. Ao movimento melódico inicial ascendente de 4.a corresponde uma modulação de abertura, que se opõe simetricamente à modulação final de fechamento, produzindo um efeito de sentido de silabação e, conseqüentemente, de pulsação: 


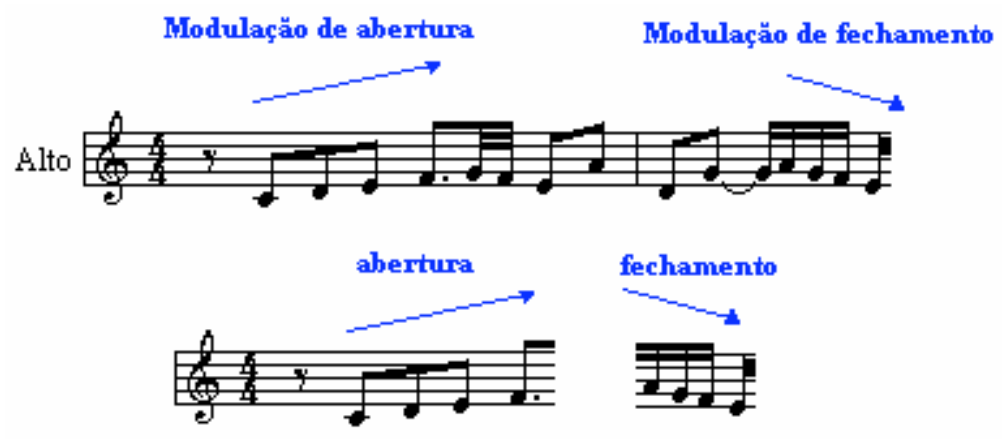

Tal pulsação se verifica também na instância harmônica, tendo-se em conta sua virtualização estendida às extremidades do segmento, determinando acordes de tônica, e valendo-nos do modelo de Schenker para considerarmos como pertinentes apenas as funções cadenciais:

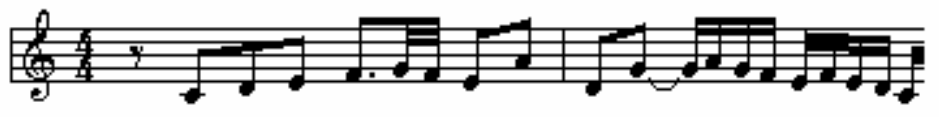

(T)

(S)

(D)

(T)

A própria cadência $\mathrm{T}-\mathrm{S}-\mathrm{D}$ - $\mathrm{T}$, que, segundo Koellreutter, corresponde respectivamente a repouso - afastamento - aproximação - resolução, já guarda em si um princípio silábico de pulsação, o que aliás reforça a proposta de abordagem silábica do discurso musical apresentada em capítulo anterior deste trabalho. De qualquer forma, a silabação verificada nas instâncias melódica e harmônica do discurso, mais especificamente seu movimento final de implosão, geram um efeito de sentido de terminatividade que, pelo próprio quadro tensivo descrito em f), exige, para a continuidade do discurso, um novo movimento de abertura, mas agora iniciando em estado mais intenso que aquele do primeiro compasso. A apresentação da resposta, corresponde exatamente a essa necessidade do discurso, à medida que representa uma abertura modulatória e, por estar no grau da dominante, um tensionamento harmônico.

Podemos dessa forma constatar com que organicidade o rígido esquema formal da fuga se apresenta nesse exemplo. Conforme vimos, a teoria musical apenas nos dá elementos para reconhecer os elemento da fuga e alguns dos mecanismos de derivação motívica que estruturam o texto. Associando-se-a porém à teoria semiótica, foi possível mergulhar muito mais profundamente na estrutura da composição, sendo possível encontrar algumas respostas sobre o como e o porquê de alguns efeitos de sentido. Sobretudo, verificamos uma íntima relação entre tensividade aspectualizada no discurso e transformações narrativas, num processo que desde o início recupera o próprio conceito de percurso gerativo. Pudemos ainda elaborar cada transformação do material motívico enquanto alteração juntiva de um sujeito com os valores do sistema, possibilitando uma real compreensão dos mecanismos de estruturação do discurso musical.

Entretanto, uma análise tão aprofundada de um trecho que, embora seja definitivamente o mais relevante do texto em questão, é relativamente curto, pode parecer, ainda que interessante, pouco operacional. Tal crítica não se sustentará 
todavia se ficar claro que na análise de um trecho como esse, descortinam-se já os principais mecanismos de organização estrutural e semântica de um texto musical, de forma que o esforço inicial é compensado por fornecer ao pesquisador um instrumental poderoso pelo qual a investigação do restante da partitura é facilitada sobremaneira (mas não por uma simplificação do texto, como no caso do modelo schenkeriano). Ou talvez a resposta a essa crítica seja que não há como mergulhar no estudo do percurso gerativo na música sem esse grau de detalhamento, sob o risco de se cair no superficialismo, em uma incompletude flagrante e insatisfatória ou na demonstração do óbvio, como declarar que uma fuga é uma fuga, uma sonata segue a forma sonata ou que a música tonal tende a se estruturar sobre uma cadência tonal. Em todo caso, para dirimir nossas dúvidas, daremos continuidade à nossa análise da exposição da fuga de Bach.

A teoria musical ensina que há dois tipos básicos de fuga no que tange à relação sujeito-resposta: a fuga real e a fuga tonal. Por fuga real se entende aquela em que sujeito e resposta diferem apenas pela altura inicial, tratando-se pois a resposta de uma transposição exata do sujeito. Por fuga tonal entende-se aquela onde ocorrem mutações no momento da transposição de maneira a adequar a resposta à nova tonalidade, diferindo assim sujeito e resposta não apenas pela altura inicial, mas, eventualmente, por sua própria estrutura intervalar interna. Contudo, conforme vimos até agora, a estrutura intervalar é de uma importância decisiva para nosso modelo de análise, e uma alteração nela pode implicar uma total modificação do quadro tensivo fórico em questão. Um exame do material nos revela entretanto tratarse de uma fuga real, ou seja, aquela onde sujeito e resposta apresentam a mesma estrutura intervalar:

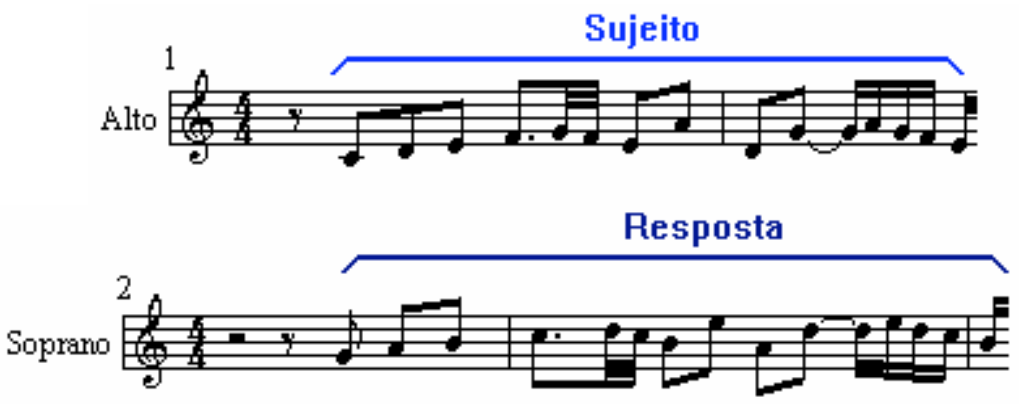

A defasagem entre um sujeito começando no primeiro tempo e uma resposta começando no terceiro não parece pertinente, devendo-se a questões de grafia musical da época (a fonte é uma edição Urtext), e não de acento rítmico, caso que obrigaria a uma reavaliação do quadro tensivo do segmento. Não havendo pois diferenças melódicas ou rítmicas a considerar, podemos aproveitar os resultados colhidos na etapa anterior no que tange a essas duas instâncias. A grande diferença a se relevar é aquela referente ao quadro harmônico, tanto em seu aspecto vertical (identificação de acordes e funções harmônicas) quanto horizontal (polifonia).

Iniciemos então nossa consideração da instância harmônica a partir de uma perspectiva horizontal. Temos aqui um trecho a duas vozes: 


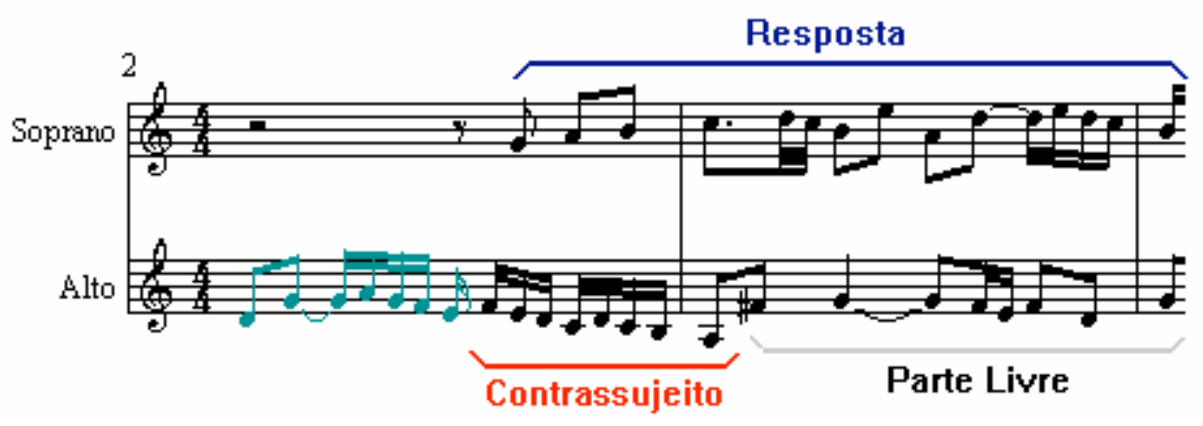

Embora possamos supor que a estrutura intervalar da resposta seja análoga àquela do sujeito, mesmo assim, para efeitos de uma abordagem linear, é necessário partir da análise da estrutura intervalar de contralto para que possamos em seguida estudar sua estrutura harmônica propriamente dita. A teoria musical nos aponta que podemos dividir essa linha morfologicamente em duas sessões distintas: o contrassujeito, aqui cumprindo sua função essencial, ou seja, o acompanhamento contrapontístico do sujeito/resposta; e uma parte livre, em que uma maior liberdade melódica tem por finalidade "completar a harmonia e assegurar a pureza do estilo"62. Iniciemos agora, pois, fazendo algumas considerações a respeito da estrutura do contrassujeito. Vejamos a figura abaixo:

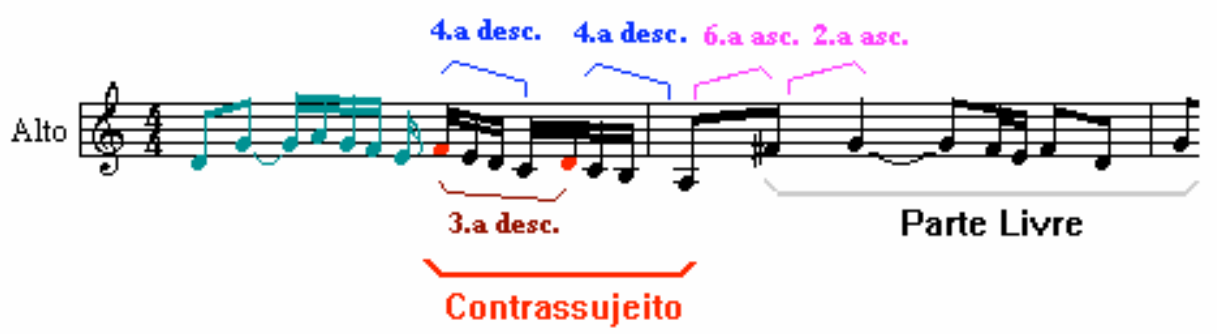

Verifica-se que o contrassujeito é composto por um grupo de semicolcheias organizado segundo uma progressão escalar descendente de 4.a justa, e que cada termo da progressão dista uma 3.a menor descendente de seu antecessor. Quebra-se tal progressão exatamente na transição entre o contrassujeito e a parte livre, demarcando claramente uma transformação de estado em que o termo seguinte da progressão é substituído pelo intervalo de 6.a maior ascendente, ao qual se segue um intervalo de 2.a menor ascendente. A ruptura de continuidade não só da progressão mas da próprio organização intervalar da peça pode parecer nesse momento à primeira vista extremamente marcante. Faz-se mister portanto um estudo mais aprofundado da questão.

O primeiro ponto a ser relevado é que o fato de se introduzir um intervalo de 6.a maior ascendente na peça não representa verdadeiramente um elemento novo. As razões para isso são de ordem musical. O intervalo de 6.a maior ascendente é, na verdade, a inversão exata do intervalo de 3 .a menor descendente, o que os torna equivalentes:

\footnotetext{
${ }^{62}$ Silva 1949:22
} 

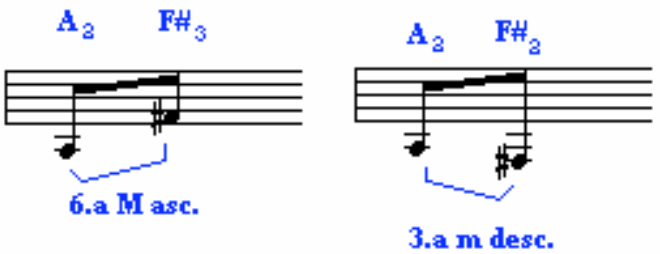

Assim, numa breve explicação: partindo-se de uma nota qualquer $\mathbf{x}$ e saltando-se um intervalo i, chega-se a uma nota $\mathbf{y}$; partindo-se novamente de $\mathbf{x}$ e saltando-se a inversão de $\mathbf{i}$, chega-se à mesma nota $\mathbf{y}$, só que em outra oitava. Desta forma, concluímos que o intervalo de 6.a maior que separa o contrassujeito da parte livre equivale no discurso ao intervalo de 3.a menor descendente que, para efeitos de análise do nível da sintaxe narrativa, chamamos de $\mathrm{S}_{2}$.

Apesar dessa demonstração bastar para vermos o trecho em questão não mais como um elemento estranho integrando-se ao sistema, há uma outra observação da máxima relevância a ser feita em relação a esse caso. Voltemos ao contrassujeito:

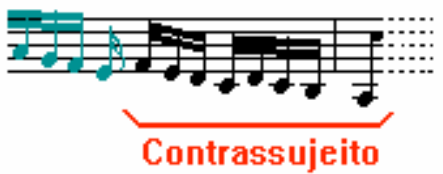

Conforme vimos, trata-se de uma progressão escalar de 4.a J descendente espaçada por intervalos de 3.a menor descendente e composta por semicolcheias. Verifiquemos quais seriam os termos seguintes caso a progressão tivesse continuidade:

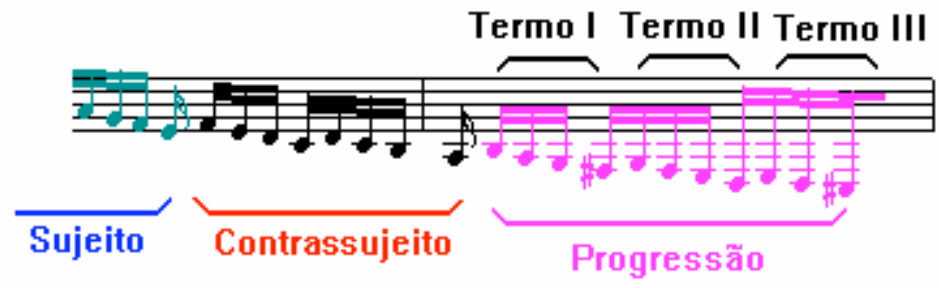

A última nota do sujeito, um lá, é conduzida pelo Termo I até um fá\#, resultando num intervalo escalar de 3.a menor descendente. Por outro lado, a primeira nota do Termo II, um sol, forma com a nota anterior um intervalo de 2.a menor ascendente, conforme a figura abaixo: 


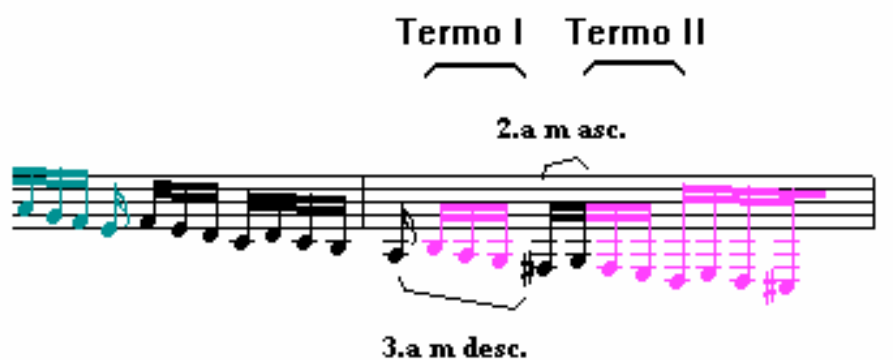

Comparemos agora esse resultado com o trecho musical a que se refere:

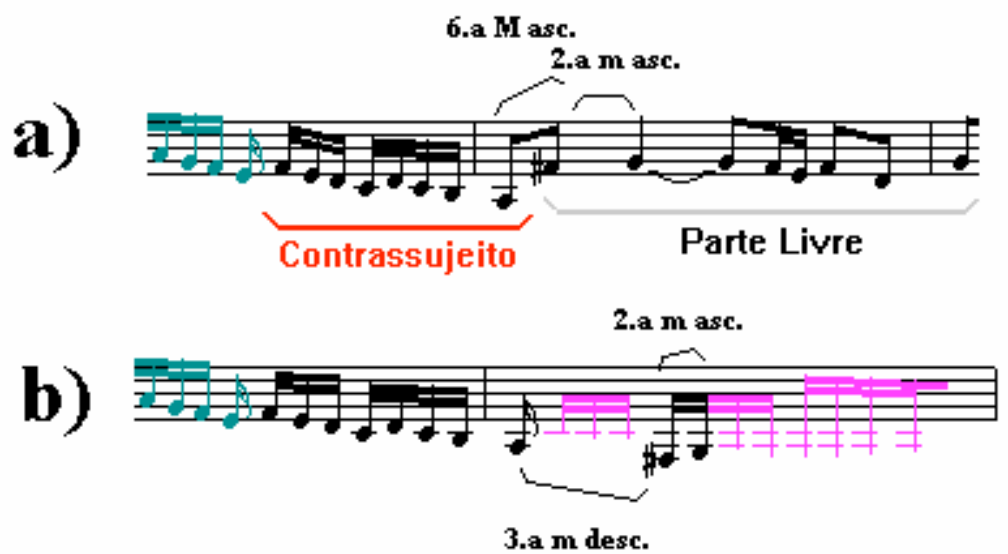

Ora, já tendo sido apresentada a relação entre um intervalo e seu inverso, podemos inferir através do confronto entre a) e b) que o primeiro representa uma contração do segundo, portanto, uma sua intensificação. Isso porque:

i) os intervalos de 6.a maior ascendente (a) e 3.a menor descendente (b) são equivalentes, porém, ao invés do fá\# ter sido atingido após 1 tempo, conforme seria se cumprida a expectativa virtualizada pela progressão, ele surge após $1 / 2$ tempo, implicando uma aceleração da temporalidade, portanto, uma contração;

ii) as notas fá\# e sol, ao invés de serem apresentadas na segunda oitava, como se esperaria a partir da progressão, surgem na terceira oitava, implicando tensionamento melódico e timbrístico.

Fica assim demonstrado como esse trecho inicial da parte livre se relaciona com os elementos estruturais encontrados na primeira parte de nossa análise e de que maneira a transformação desses elementos representa no presente caso uma intensificação. Assim, a transformação de estado sofrida aqui pelo material melódico corresponde, segundo a nomenclatura aqui utilizada, a uma conjunção de $S_{2}$ (discursivizado como intervalo de 3.a menor) com um valor intenso em relação àquele seu anterior.

Prossigamos então com a análise do restante da parte livre. Identifiquemos a estrutura intervalar do segmento: 


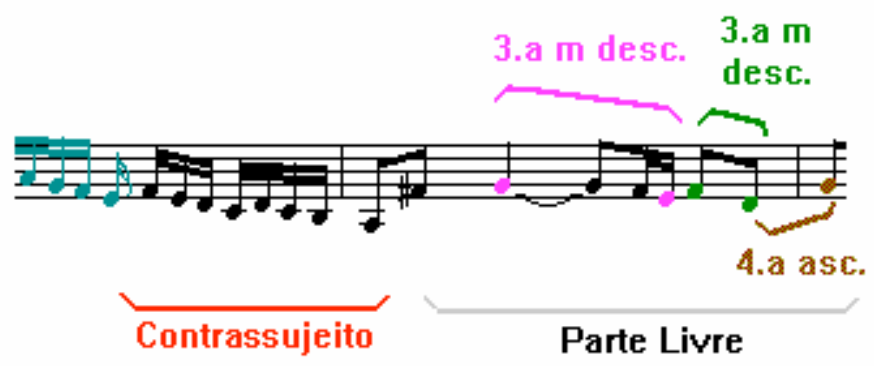

Inicialmente, verifica-se a presença de uma 3.a menor descendente em progressão escalar. A primeira nota do intervalo, um sol, tem duração de $1 \frac{1}{2} 2$ tempo, sendo excepcionalmente longa no contexto dessa peça. Tal dilatação temporal denuncia um claro predomínio da extensividade, ocorrendo pois uma nova transformação de estado em que $\mathrm{S}_{2}$ passa a estar agora em conjunção com os valores de extensão do sistema. O intervalo seguinte é novamente uma 3.a menor descendente, porém agora em intervalo direto e em colcheias, indicando contração temporal e intensão em relação a seu antecessor imediato. Segue-se a esse um intervalo de 4.a justa ascendente que, analogamente, chamamos anteriormente de $\mathrm{S}_{1}$, e que se encontra aqui em conjunção com valores intensos em relação à sua situação enquanto elemento do contrassujeito. Para visualizar a trajetória de $S_{1}$ e $S_{2}$ em sua situação juntiva em relação aos valores do sistema, traçamos o gráfico abaixo:

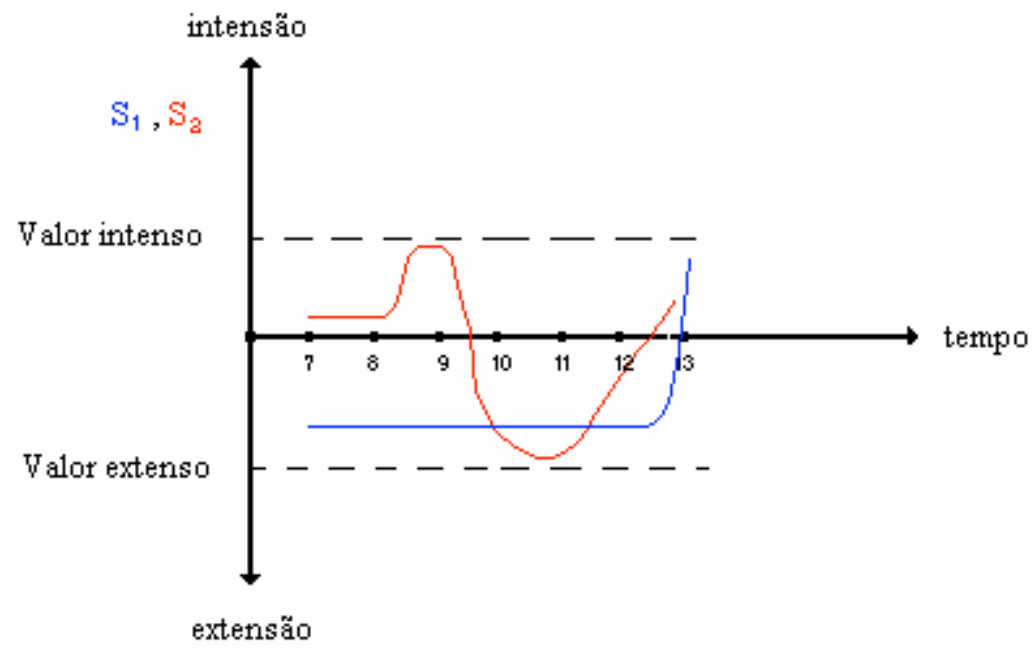

\footnotetext{
linha azul = trajetória dos valores em conjunção com $S_{1}$

linha vermetha $=$ trajetória dos valores em conjunção com $S_{3}$
}

Observa-se uma nítida relação entre variações tensivas e transformações de estado. $\mathrm{O}$ pico intensivo de $\mathrm{S}_{2}$ marca o fim das progressões descendentes, numa clara quebra de continuidade, enquanto que o pico extensivo que lhe segue também está relacionado a uma quebra de continuidade onde a linha melódica muda da direção ascendente para a descendente. A súbita intensificação final de $S_{1}$, analogamente, reverte essa mesma descendência em ascendência.

Tendo examinado a linha de contralto e sendo aquela de soprano, conforme discutido anteriormente, análoga àquela do sujeito, podemos finalmente 
estudar o trecho em questão sob uma perspectiva vertical. Voltemos pois à partitura com as indicações dos elementos da fuga:

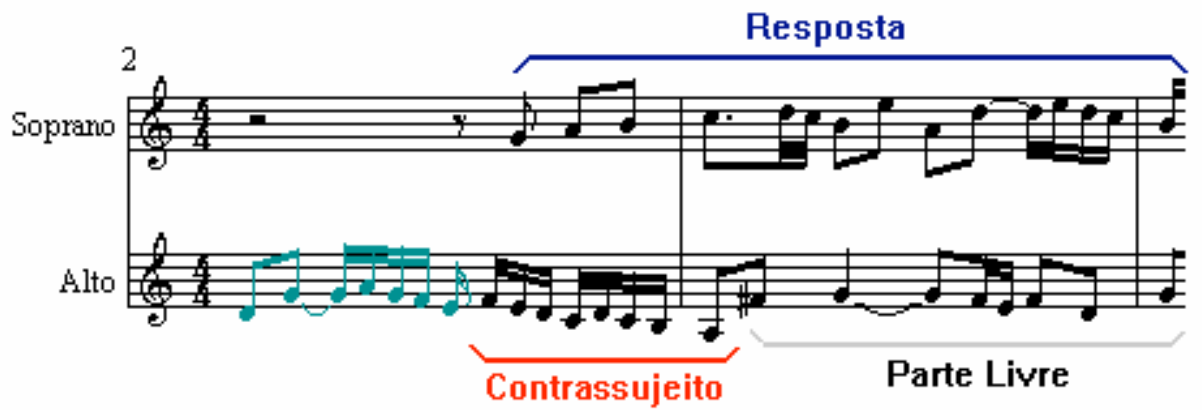

Uma análise harmônica ${ }^{63}$ nos leva ao seguinte resultado:

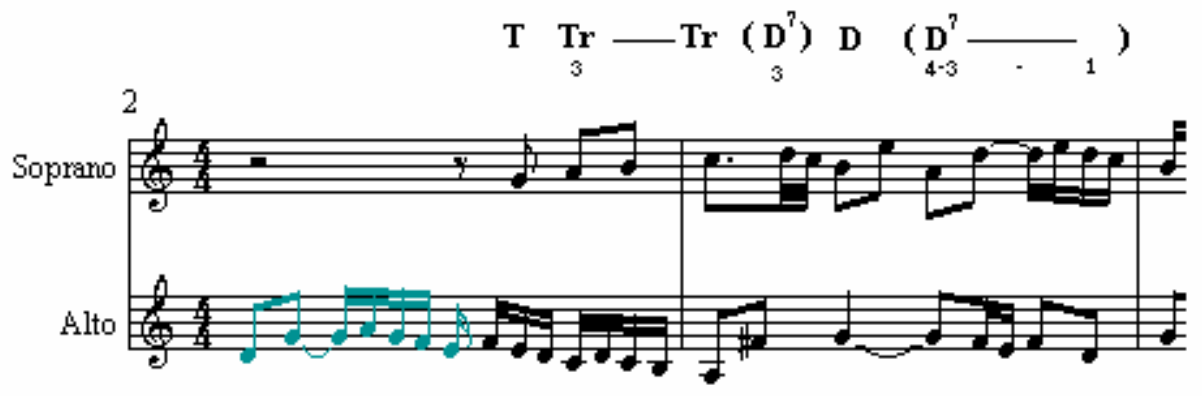

Consideramos mais prática nesse caso específico a utilização apenas da harmonia funcional enquanto abordagem harmônica, por sua concisão e objetividade num contexto como esse. Confrontemos desde já o quadro harmônico da sessão com a configuração tensiva da linha de contralto, que acabamos de estudar.

As funções harmônicas de tônica ( $\mathbf{T}$ e $\mathbf{T r}$ ) prevalecem no trecho inicial, coincidindo com a extensividade da progressão descendente do contrassujeito. $\mathrm{O}$ surgimento da dominante individual corresponde ao salto de 6.a maior, ou seja, à intensão resultante da contração temporal da progressão melódica. A dominante propriamente dita, que vem logo em seguida e que é harmonicamente menos tensa que o acorde anterior, ocorre no momento em que se inicia a extensão da 3.a menor em contralto. Já a última dominante individual, que aparece inicialmente invertida e suspensa, posteriormente resolvendo a suspensão e assumindo posição fundamental, constitui o acorde mais tenso do segmento, mas que sofre uma distensão ao passo que suas tensões internas vão atingindo suas respectivas resoluções. A instância melódica que a acompanha, entretanto, sofre um processo reverso, ou seja, de gradual intensão. A organicidade do processo nesse ponto remete à idéia de uma transferência de tensão da instância harmônica para a melódica. Para que isso não pareça excessivamente abstrato, lembremos que a instância harmônica é, em última análise, a resultante do aspecto tensivo da sobreposição de diversas instâncias melódicas. Por nosso caso se

\footnotetext{
${ }^{63}$ Consideram-se os acordes virtualizados, já que a rigor não se pode falar de harmonia a duas vozes; lembremos que a justificação de tal procedimento tem fundamentação de ordem interdiscursiva, viabilizada pela coerência e unidade do repertório tonal, conforme já discutido anteriormente.
} 
tratar de um contraponto a duas vozes, podemos nos dar ao luxo de acompanhar seu desenrolar sob um ponto de vista horizontal, compreendendo de que maneira essa simultaneidade gera, verticalmente, a instância harmônica. Para isso, confrontemos os quadros tensivos das duas linhas melódicas que o compõem:

SOPRANO

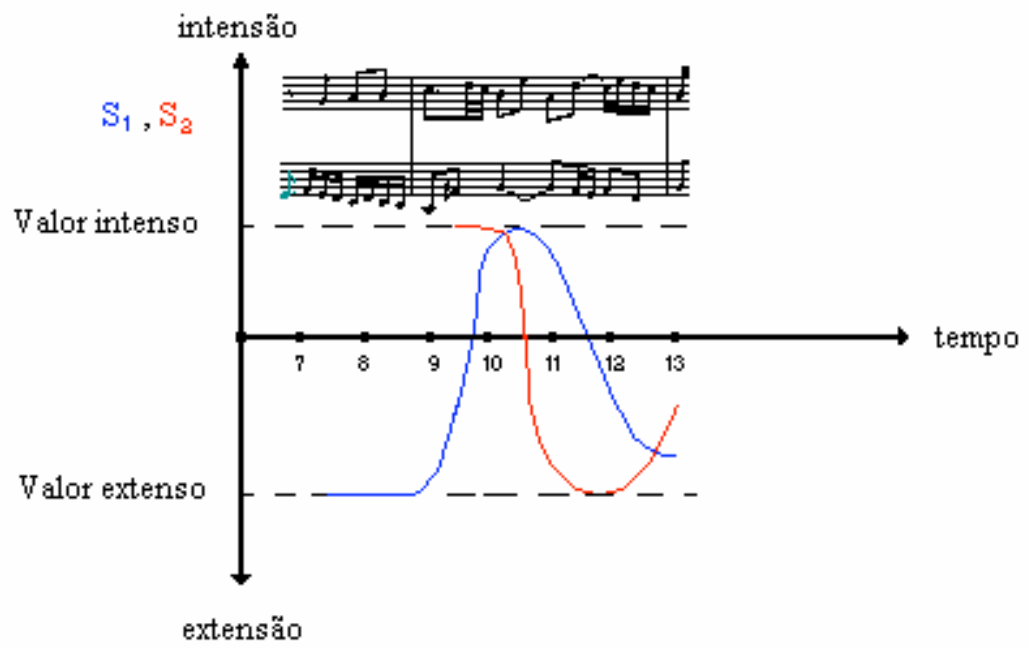

CONTRALTO

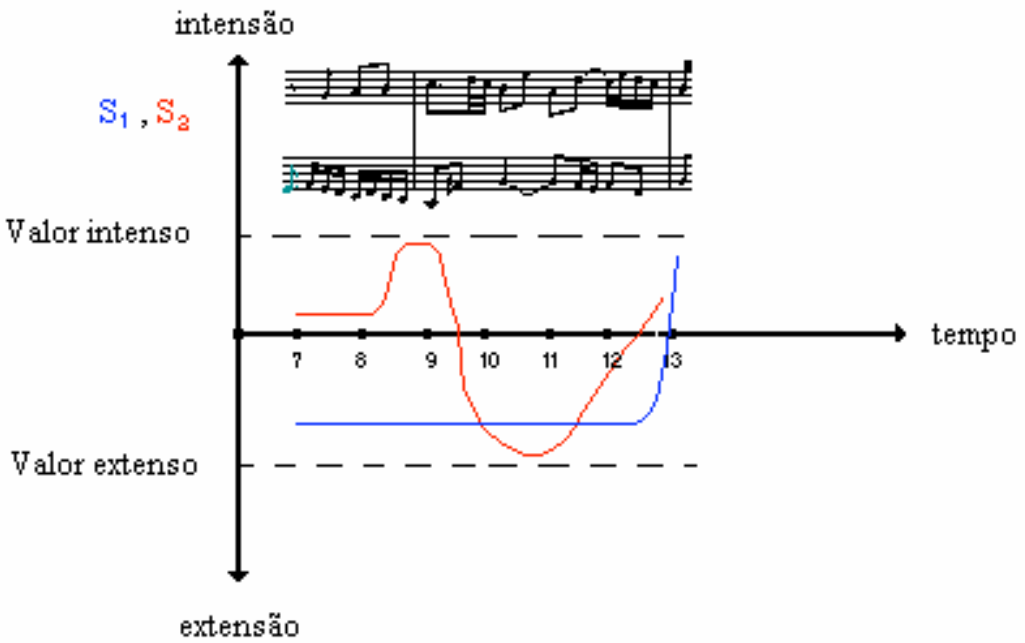

linha azul = trajetória dos valores em conjunção com $S_{1}$ linha vermelha $=$ trajetória dos valores em conjunção com $\mathrm{S}_{3}$

No início do trecho, há em ambas as vozes um nítido predomínio de $\mathrm{S}_{1}$, em conjunção com os valores de extensão do sistema; na instância harmônica, encontramos as funções de tônica, indicando repouso. Entre os tempos 9 e 10 , a entrada de $S_{2}$ em conjunção com valores de intensão em ambas as vozes acarreta mudanças de estado em soprano e contralto, alterando seu direcionamento melódico; harmonicamente, isso corresponde à dominante individual (no caso, dominante da dominante), indicando um dos picos de tensão harmônica ocorrendo paralelamente a extremos de intensão nas duas vozes. A transformação de estado seguinte corresponde 
à conjunção de $\mathrm{S}_{2}$ com valores de extensão, e ocorre na região da dominante, levando à paralisação da temporalidade em contralto e à ritmização, sob a forma de progressão descendente, em soprano (a ritmização, nesse caso, trabalha contra a intensão, normatizando e emprestando previsibilidade ao devir). No tempo 11, a conjunção de $\mathrm{S}_{1}$ com os valores de intensão em soprano choca-se contra a extensão de $\mathrm{S}_{2}$ em contralto, terminando por contaminar essa voz, atuando assim como destinador que manipula $\mathrm{S}_{2}$ em direção a um programa de intensificação. A atribuição de valores modais (que se discursivizam nesse caso como uma progressão em aceleração) pelo destinador ao destinatário corresponde ao pico de tensão harmônica, com o acorde de dominante individual (no caso, dominante da dominante) suspenso e invertido. Assim, dos tempos 11 a 13, a harmonia, embora haja um processo de intensificação em contralto, segue entretanto o percurso do destinador, soprano (a "melodia"), onde, inversamente, predomina a distensão que levará $S_{1}$ de volta à conjunção com os valores de extensão, e a harmonia à resolução da dissonância. De qualquer forma, o quadro tensivo final, em ambas as vozes, é mais intenso que o inicial, o que se reflete na instância harmônica pela finalização na dominante, contrastando com o início na região da tônica.

Vimos assim, ainda que brevemente, de que maneira interagem as diversas instâncias do discurso musical no processo narrativo, relacionando as transformações dos estados de coisas com alterações juntivas entre sujeitos e valores. Compreendemos ainda esses valores basicamente enquanto conversão de uma organização valencial ordenada sob a forma de aspectos tensivos. Constatamos que a cada transformação de estado foi possível relacionar ou um pico tensivo (quer seja intenso ou extenso) ou o fechamento de uma estrutura silábica imediatamente anterior ao evento (e a conseqüente abertura de uma nova com a introdução de novo material). Foi possível ainda observar que as menores estruturas actanciais portadoras dos valores do sistema discursivizam-se não como temas extensos, como por exemplo o sujeito de uma fuga, ou mesmo como motivos rítmico-melódicos; trata-se mais propriamente de um ou dois intervalos principais, geralmente portadores de valores contrários. Assim, para se alcançar uma visão mais aprofundada do percurso gerativo, há que se tomar o discurso musical a partir de unidades mínimas, de atores verdadeiramente elementares, e acompanhar as transformações nas relações desses com os valores do sistema e entre eles mesmos. Pudemos de fato detectar relações intersubjetivas no texto analisado, reconhecendo a polêmica e a manipulação. Entretanto, para chegarmos à macroforma de uma composição, um procedimento de análise tão detalhado demandaria aparentemente um trabalho extremamente árduo e extenso. Cabe agora, portanto, apoiarmo-nos em alguns dos resultados obtidos até o momento para nos arriscar a uma abordagem, ainda que ligeiramente superficial, de um texto mais longo, de forma a ao menos vislumbrarmos que tipo de contribuição podem a semiótica e a morfologia musical oferecer uma à outra. Para isso, nada melhor que tomarmos logo como exemplo um texto que apresente a estrutura morfológica mais consagrada de todo o repertório ocidental: a forma sonata.

A forma sonata organiza-se segundo o seguinte diagrama: 


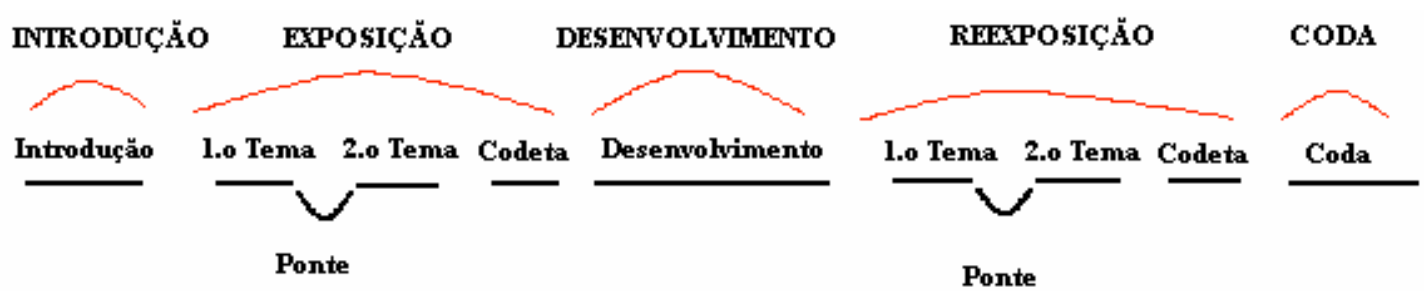

A introdução não é uma sessão obrigatória, podendo sua extensão variar de apenas alguns acordes a um trecho relativamente longo, mas sempre bem menos extenso por exemplo do que a exposição propriamente dita. Vale ainda ressaltar que ela pode (como no caso dos movimentos I e IV da Sinfonia n.o 1, de Brahms) ou não apresentar uma relação estrutural evidente com o restante da obra. Quanto às outras sessões, vale a pena citar a definição sucinta de Rosen:

la exposición (Exposição) se inicia con un tema o grupo de temas en la tónica (1.o Tema), seguido de la modulación hacia la dominante (Ponte) y un segundo grupo de temas (2.0 Tema); tras repetirse la exposición, sigue el desarrollo (Desenvolvimento), donde los temas se fragmentan y combinan en diversas tonalidades; termina con la vuelta a la tónica y la recapitulación de la exposición (Reexposição), esta vez con el segundo grupo de temas en la tónica; puede tener una coda opcional. (Coda) ${ }^{64}$

A codeta, não especificada acima por Rosen, encontra em Bas uma interessante análise estética:

Col II tema è già completa la sostanza dell'esposizione tematica che constituisce la prima grande parte $A$ della forma sonata; è per ciò possibile passare addirittura così allo svolgimento che occupa la seconda parte $B$. Ma è già noto come il senso di buona chiusa, sia nelle intere forme, e sia anche solo nelle loro parti e negl'istessi periodi musicali, conduca ad un prolungamento in guisa di coda. Questo hanno sentito i grandi Maestri. Essi, come per rinsaldare l'unità di questa prima parte del I.o tempo di Sonata, aggiunsero all'esposizione del II .tema delle cadenze, delle appendici, più o meno ampie, più o meno caratteristiche e significative: le così dette "codette". ${ }^{65}$

Os temas I e II em geral apresentam características divergentes: enquanto o primeiro é em geral predominantemente rítmico e motívico, o segundo costuma tender ao melodismo. Essa interessante diferença de articulação entre os dois se semiotiza como uma oposição aspectual do tipo descontinuidade $\mathbf{x}$ continuidade, o que imediatamente nos remete às categorias intensão $\mathbf{x}$ extensão. Refletir a respeito das implicações dessas constatações nesse momento, todavia, nos desviaria de nosso atual objetivo, que se resume a uma breve aplicação de nosso modelo de análise ao estudo da morfologia musical. Assim, interessa-nos nesse caso sobretudo o fato de a forma sonata repousar sobre uma oposição tonal entre os dois grupos temáticos principais, e de haver uma sessão responsável pela transição entre as duas respectivas tonalidades. Tal pode ser entendido como uma transformação de estado em que inicialmente os grupos temáticos aparecem em conjunção com uma dada tonalidade, para em seguida estarem em disjunção com ela e em conjunção com uma segunda

\footnotetext{
${ }^{64}$ Rosen, $1972: 37-38$

${ }^{65}$ Bas, 1955:297
} 
tonalidade. A oposição entre valores tonais é assumida pelos dois temas, estabelecendo-se assim uma relação polêmica entre ambos. Nas palavras de Bas,

il I. tema è gagliardo, deciso, rapido, mentre il II. è melodioso, cantabile. Questo basta già a far riconoscere un contrasto, un'opposizione fra i due temi; opposizione intorno a cui s'aggirà tutta la sostanza della forma di Sonata. Difatti, dopo enunciato questo stato di cose nell'esposizione tematica (ch'è in certo modo la presentazione, la sfida fra i due combattenti), lo svolgimento sarà la fase più viva, la lotta fra questi elementi principali (accompagnati dai loro ausiliari), di cui uno, il primo, trionferà sull'altro nella ripresa, conducendoselo dietro nel proprio tono. ${ }^{66}$

Para que nossa compreensão da forma sonata não se limite a uma perspectiva excessivamente técnica, vale fazer uma breve interrupção de modo a levantarmos algumas observações de cunho extra-musical. É interessante notar que a forma sonata se apresenta de certa forma como um jogo de cartas marcadas, onde já se sabe de antemão que a tonalidade negada será reafirmada. Um leitor de Bakhtin e de Lucáks se sentiria aqui tentado a tecer uma série de analogias. A transformação estilística na musica ocidental do rococó ao classicismo e desse ao romantismo pode ser vista como um processo gradual de complexificação estrutural e de questionamento da tonalidade (Webern, 1960:69). Peças curtas construídas sobre harmonias relativamente simples foram dando lugar a (sem deixar entretanto de coexistir com) longas sinfonias em que modulações se sucediam de tal maneira que desnorteavam totalmente o ouvinte de sua referência tonal inicial. Tudo isso num período histórico em que a estrutura de poder das monarquias absolutistas se mostrava incompatível com os interesses da burguesia em ascensão, que por sua vez passou a assumir os valores do liberalismo e do racionalismo para justificar política e filosoficamente sua posição. Os princípios de igualdade e liberdade eram inconciliáveis com os privilégios e o imobilismo do estado absolutista, e o questionamento crescente do antigo regime e de seu sistema de valores pode parecer de fato ter encontrado uma crônica velada no cerne da forma sonata. Fatores extramusicais reforçam ainda essa visão: Beethoven, cujo nome se associou indissoluvelmente àquela forma musical, dedicou sua Sinfonia Heróica a Napoleão Bonaparte quando esse aparecia como defensor do ideário revolucionário, e rasgou a dedicatória anos depois ao saber que ele se coroara imperador. Releve-se ainda a coincidência da própria sobrevida da forma sonata com o período das revoluções liberais em que, a partir de ideais racionalistas iluministas, a burguesia tomou o poder da aristocracia pondo fim às monarquias absolutistas da Europa. Há de fato um racionalismo inerente à forma sonata, podendo-se contudo reconhecer em sua estrutura polêmica tanto o antagonismo de forças sociais quanto um eco da dialética hegeliana, especialmente em Beethoven e Brahms, que se esmeravam em condensar na coda a própria síntese de todo o pensamento musical apresentado em suas composições sinfônicas. Quanto à decadência da forma sonata, há outros pontos a se considerar, que a circunscrevem dentro da falência da tonalidade e, sobretudo, da chamada música erudita enquanto principal manifestação musical do ocidente. Essa última existiu sobretudo como música funcional num contexto social onde antes a igreja e posteriormente a aristocracia detinham o monopólio da riqueza e do poder, numa concepção de sociedade extremamente polarizada entre senhores e servos. É

\footnotetext{
${ }^{66}$ Idem, p.293
} 
nesse sistema onde prevalecem os valores de exclusão, que se contrapõe ao ideário atual de universalização (por sinal implícito no termo globalização, muito em voga na mídia contemporânea), que se cristalizou o estigma do gênio criador e da obra-prima, ambos termos que apresentam valor intenso bastante marcado. Assim, desde a roupa dos músicos até o comportamento do público, personagens como o maestro, a primadonna e o compositor genial, enfim, todo o aparato sociológico relacionado à música erudita ainda hoje a associa a uma estrutura social e a um sistema de valores que foi gradativamente encontrando cada vez menos eco na sociedade contemporânea. Sua estética por sua vez se radicalizou como em nenhum momento anterior de seu desenvolvimento. Outrora sempre próxima ao que podemos chamar de raízes populares, evoluindo sem grandes receios de uma "contaminação" freqüentemente desejável, a música erudita em seu ocaso se permitiu a partir do final do século XIX alienar-se como nunca das demais manifestações musicais da sociedade, apostando tudo na concepção exclusivista do "gênio incompreendido" e do estar "muito adiante de seu tempo", investindo em um uso bastante particular da linguagem musical que não encontrou grande respaldo popular. Zilberberg e Fontanille discutem as categorias universalismo $\mathbf{x}$ exclusivismo a partir do texto de Alexis de Tocqueville já citado neste trabalho, parte de sua obra De la démocratie en Amérique, e que ilustra brilhantemente o contraste entre os dois sistemas de valores ao apontar que na democracia, "si l'on y rencontre moins d'éclat qu'au sein d'une aristocratie, on y trouvera moins de misères; les jouissances y seront moins extrêmes et le bien-être plus général..."67. Por outro lado, ao chegarmos ao final do século, tornou-se evidente para nós que a grande música dos novecento foi o jazz, que fundiu elementos das tradições musicais européia e africana (mais especificamente, afro-americana); uma música que teve origem nos bordéis de New Orleans, criada por negros pertencentes à base da pirâmide social e cuja ascensão acompanhou de perto o processo de democratização sociopolítica da sociedade americana, e que foi a verdadeira responsável pela consolidação das conquistas estéticas no campo harmônico que se tornaram o carro chefe do pensamento musical ocidental a partir de Wagner.

Feitas essas observações, temos agora elementos de diferentes áreas do conhecimento para compreender a forma sonata não como um dado estético isolado, como a apresentam os diversos manuais de teoria musical, mas como expressão cultural de uma sociedade em transformação, carregando consigo um reflexo de todo o movimento ideológico e filosófico de seu tempo. Voltemos pois agora ao encaminhamento de nossa análise, tomando a exposição do primeiro movimento da 5.a Sinfonia de Beethoven. Embora o I Tema e o II Tema tenham sido já discutidos no princípio desta dissertação, recapitularemos alguns pontos enfocando basicamente apenas aquilo que nos interessa para uma consideração da sintaxe narrativa do texto. Visando facilitar a visualização das questões musicais a serem discutidas, nossas ilustrações da partitura dirão respeito sempre à redução para piano, embora obviamente as observações em si nasçam sempre de uma reflexão sobre a grade de orquestra. Assim sendo, vamos aos 21 compassos iniciais:

\footnotetext{
${ }^{67}$ Tocqueville, 1963:28
} 

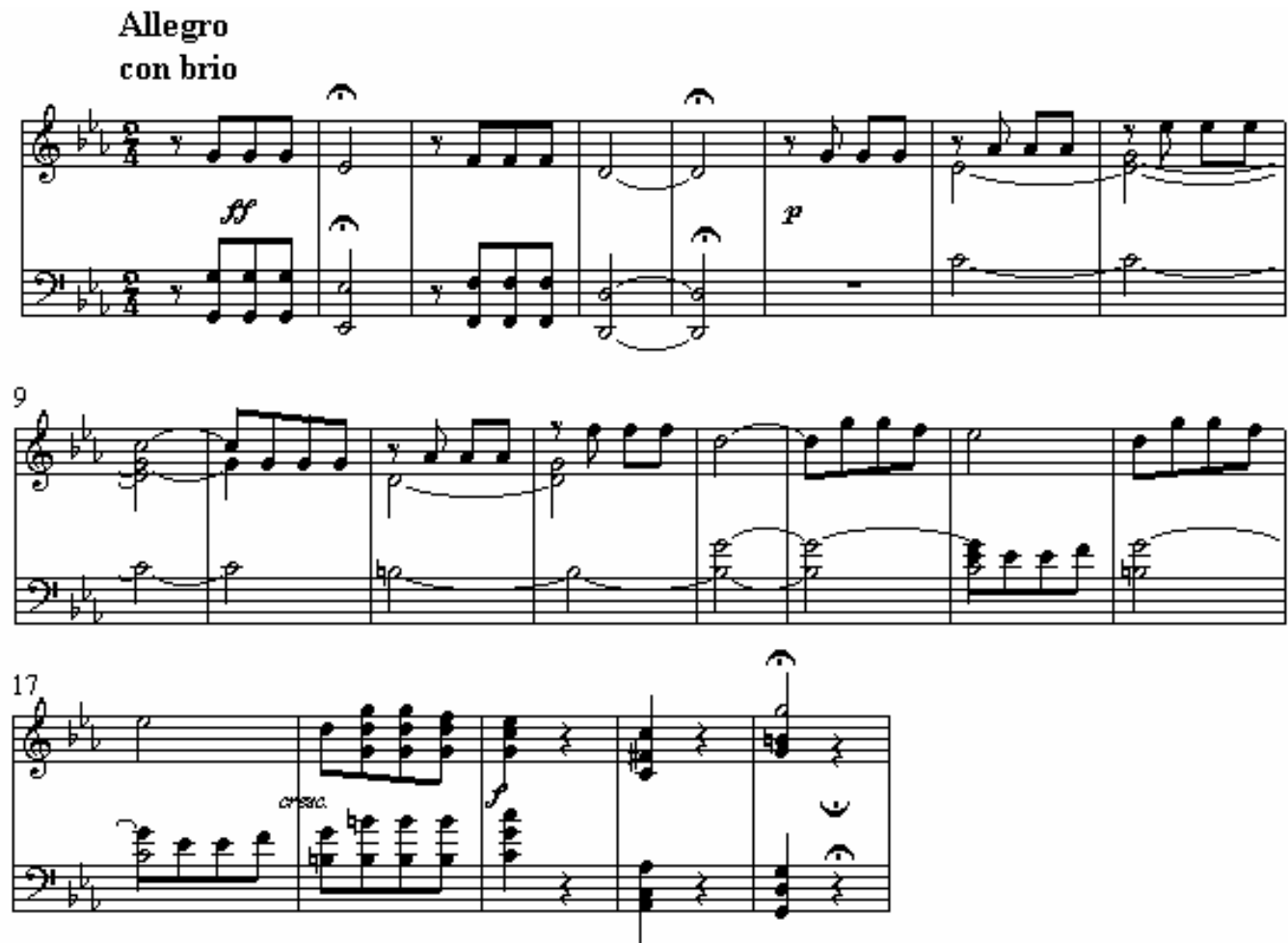

O primeiro percurso narrativo a nos chamar a atenção é aquele pelo qual o motivo principal,

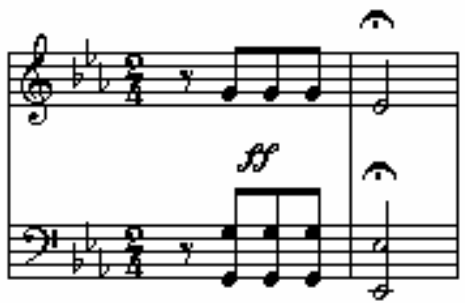

que, como vimos anteriormente, é o portador dos valores de intensão do sistema, sofre um processo gradual de extensão, que se aspectualiza temporal (pelo aumento gradativo das durações) e dinamicamente (pela diluição do fortissimo inicial no piano):

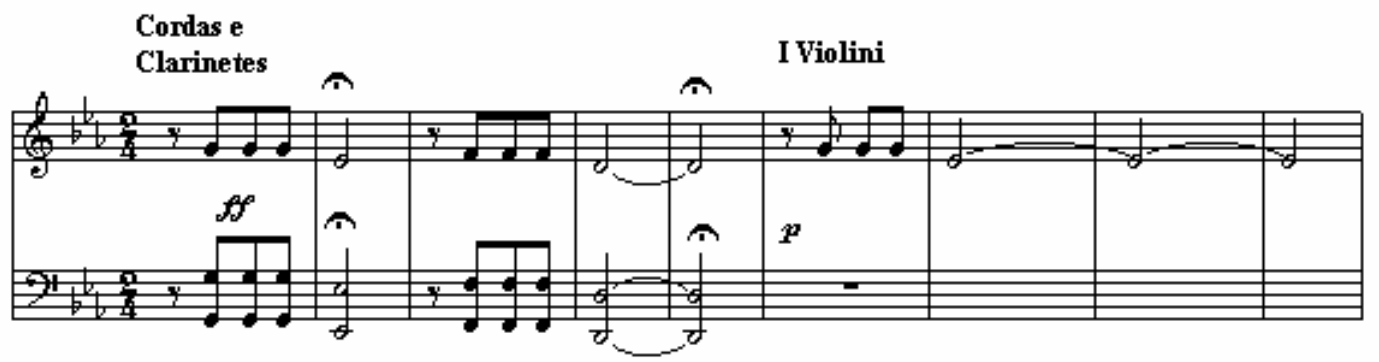

Duração: 2 compassos

Dinâmica: fortíssimo
3 compassos fortíssimo
4 compassos piano 
Conforme visto anteriormente, essa transformação foi regida por dois agentes: a 4.a justa, portadora dos valores de extensão, e o intervalo de 2.a, portador secundário dos valores de intensão. No trecho seguinte, observe-se como é a quarta que desencadeia a expansão melódica do motivo:

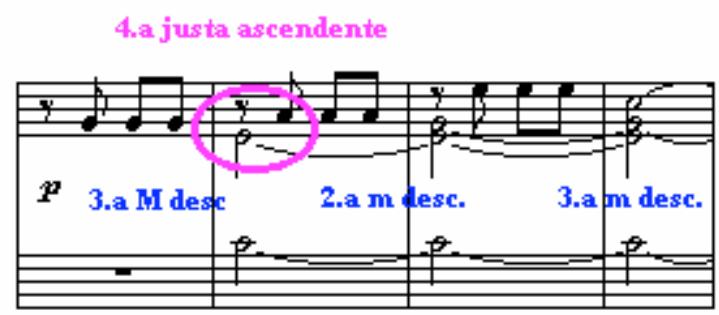

e como o intervalo de 2.a atua enquanto elemento de intensão melódica e introdutor na instância harmônica do acorde de dominante, ou seja, do acorde de tensão:

3.a m desc.

3.a m desc.

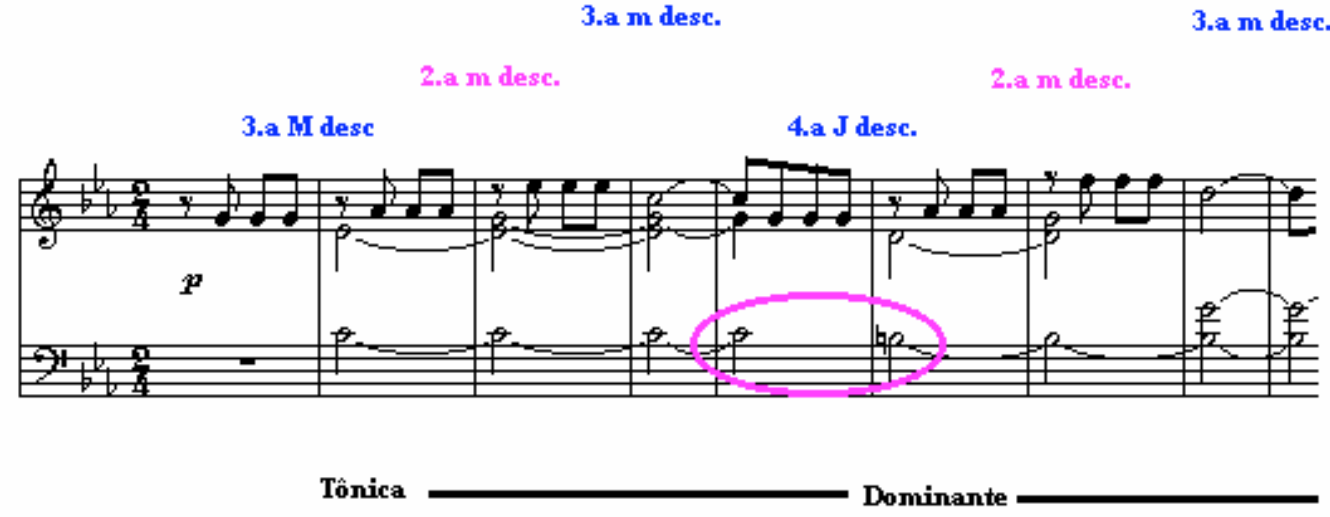

Configura-se assim o segundo percurso narrativo do texto, um percurso de intensão, que pode ser observado a partir da aceleração do intervalo de 2 .a menor e do crescendo dinâmico até o forte. Tal aceleração desencadeia um processo de discretização que conduz da continuidade e duratividade à descontinuidade e pontualidade: 

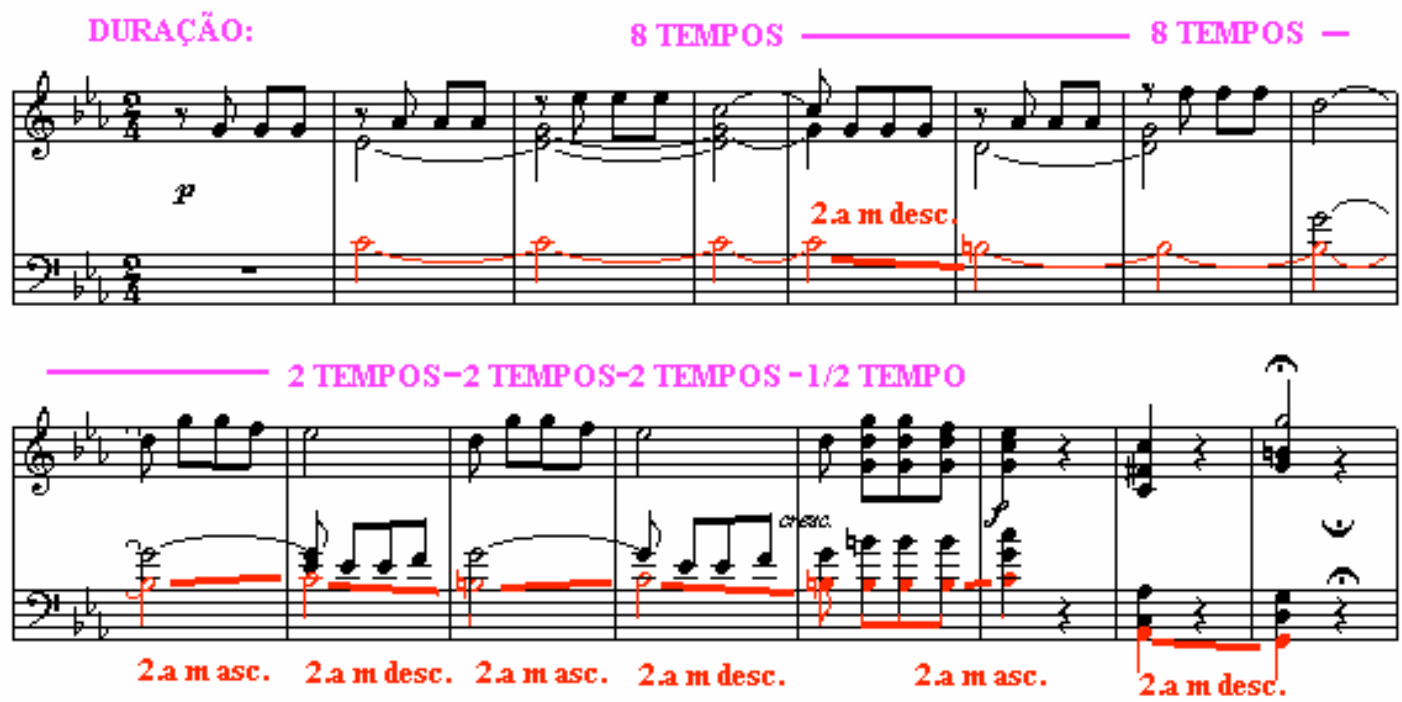

O tensionamento é marcado por uma transformação de estado na instância melódica, com a introdução do retrógrado ascendente do intervalo escalar descendente de 3.a maior:
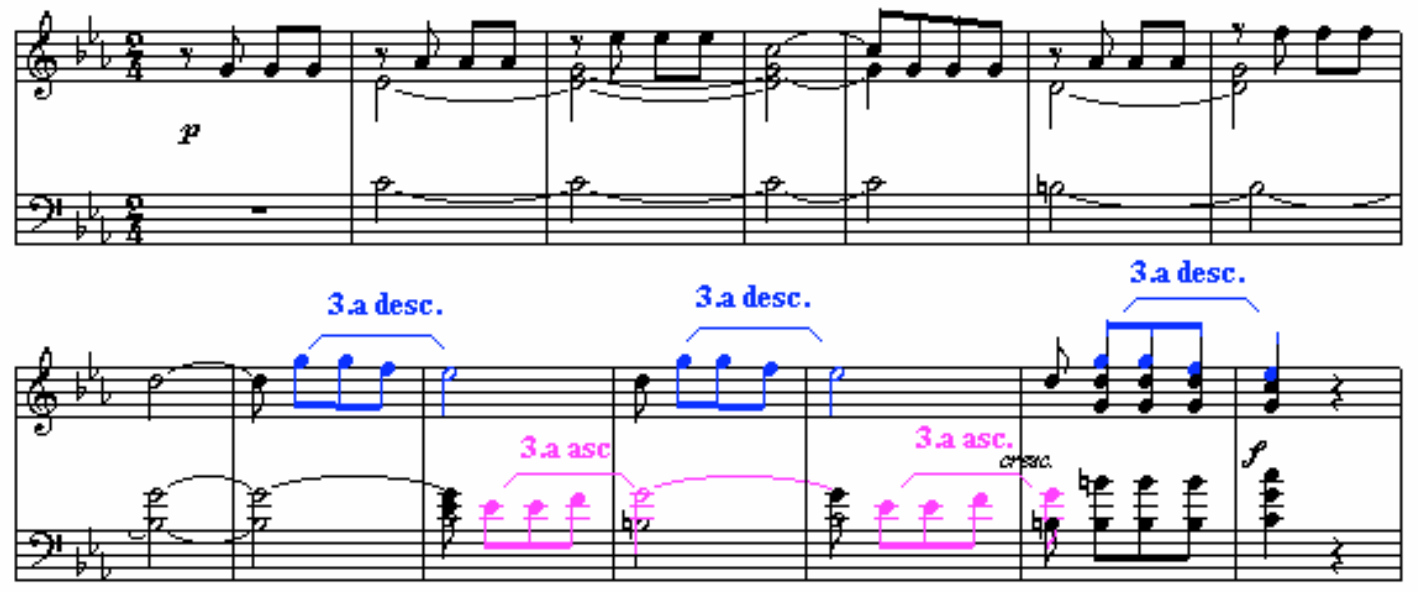

e culmina com a assunção pelo intervalo de 4.a justa dos valores de intensão do sistema através de sua inversão, o intervalo de 5.a justa, que permanece em fermata após o corte da orquestra. A fermata, ou seja, parada, assume aqui sua conotação semiótica, indiciando o acento tensivo: 


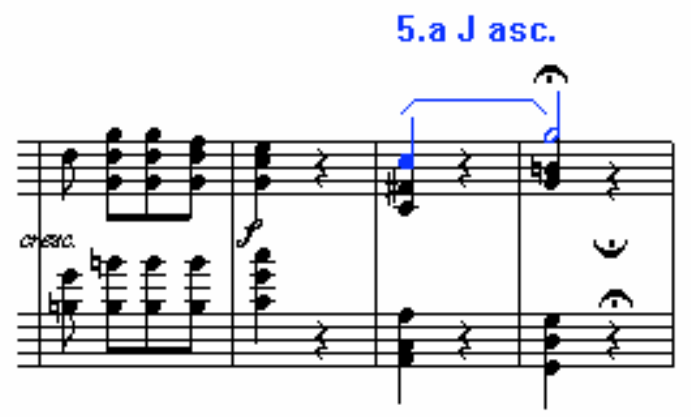

Ao passo que a 4.a justa assume os valores de intensão, seus antigos portadores, os intervalos de 3.a, sofrem uma transformação em seu estado juntivo, passando a assumir os valores de extensão. Esse processo se consuma após o clímax tensivo na instância dinâmica do discurso, que se aspectualiza no $f f$. Note-se a duratividade da 3.a menor descendente ampliada pela fermata, num procedimento discursivo análogo àquele utilizado nos compassos introdutórios da sinfonia.

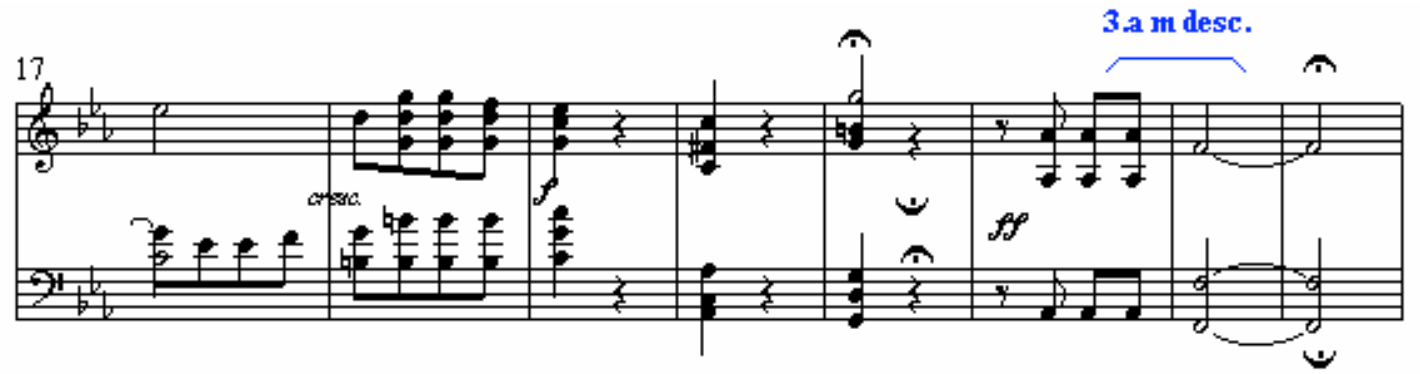

Deve-se ressalvar, entretanto, que essa analogia com o trecho inicial nos permite apenas reconhecer um processo de extensão; a confirmação da assunção dos novos valores pelo intervalo de 4.a só se dará nos compassos seguintes, em que a expansão melódica, ao invés de se dar pelo intervalo de 4.a como no compasso 7 , aparece como uma progressão de 3 .as menores descendentes:
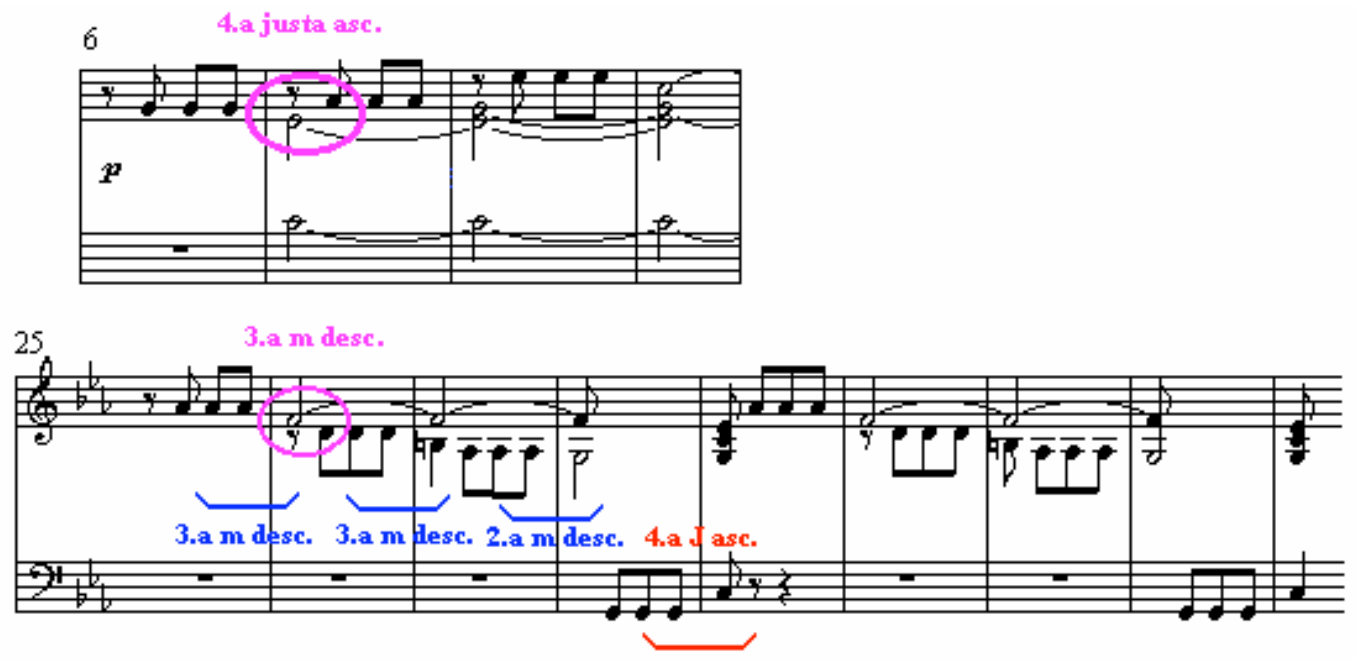
No trecho iniciado no compasso 25 , verificamos um movimento de expansão resultante da discursivização dos valores de extensão, e uma intensão intensão introduzida pelo intervalo de 2.a menor, encerrando-se a intensão com o novo portador dos valores de intensão, o intervalo de 4.a justa.

$\mathrm{O}$ confronto entre as sessões que se originam respectivamente nos compasso 6 e 25 nos revela um importante paralelismo estrutural que ganha peso ao constatarmos que cada uma dessas duas estruturas se relaciona respectivamente com a primeira e com a segunda aparição do motivo principal (que alguns teóricos apontam como a introdução da sinfonia):
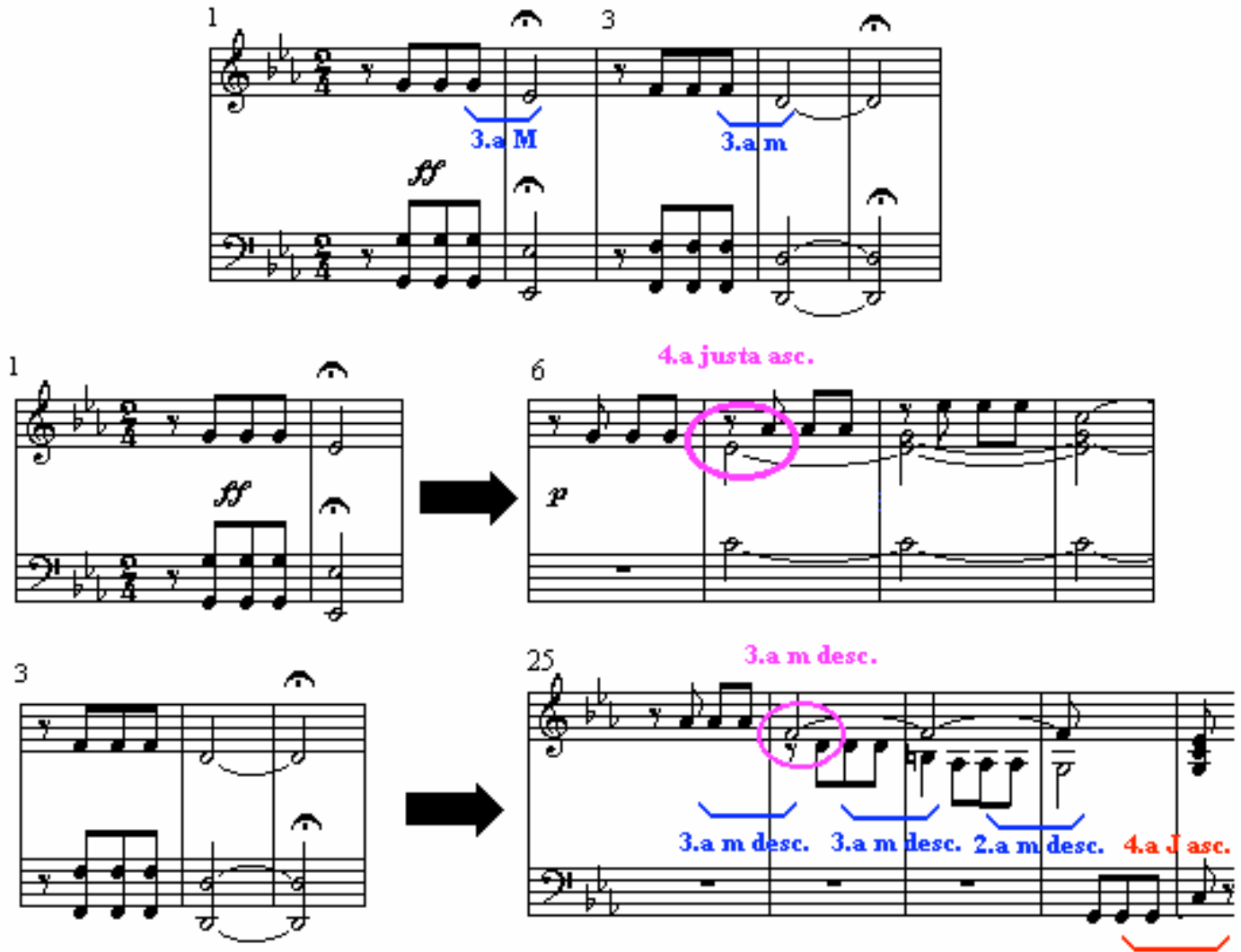

O percurso narrativo que deu origem ao intercâmbio de valores entre as duas estruturas actanciais principais (os intervalos de 3.a e 4.a) apresenta uma clara analogia com o programa inicial de extensão que averiguamos no trecho introdutório. De fato, conforme podemos observar pelo diagrama acima, os dois primeiros compassos, que apresentam os valores de intensão, desencadeiam um trecho onde prevalece exatamente um percurso tensionamento; analogamente, o programa de extensão dos compassos 3 a 5 se relaciona com o trecho que começa no compasso 25 , onde há a inversão de valores. Essa relação de concentricidade que se estabelece entre micro e macroestrutura no discurso musical, extremamente freqüente, além de ser um mecanismo que pode contribuir decisivamente para a coerência e coesão textuais, constitui mais um fator de visibilidade que singulariza o discurso musical no que tange à aplicação do modelo greimasiano. De fato, essa concentricidade é extremamente próxima ao modelo de percurso gerativo, à medida que se compreende por exemplo que é a própria organização de nível profundo da introdução (figura 
acima, à esquerda) que se discursiviza nos trechos que se lhe seguem (idem, à direita), de modo que se verifica que a semiótica nos permite passar da hipótese da teoria musical de que a composição é gerada a partir de alguns poucos motivos para a tese que procura investigar como a estrutura semântica (sobretudo tensiva) do motivo gera a própria sintaxe do texto musical.

Mas deixemos momentaneamente de lado essas importantes colocações para que a análise por si só nos forneça mais subsídios para avaliá-las. Consideremos o trecho seguinte, que corresponde morfologicamente ao início da ponte:

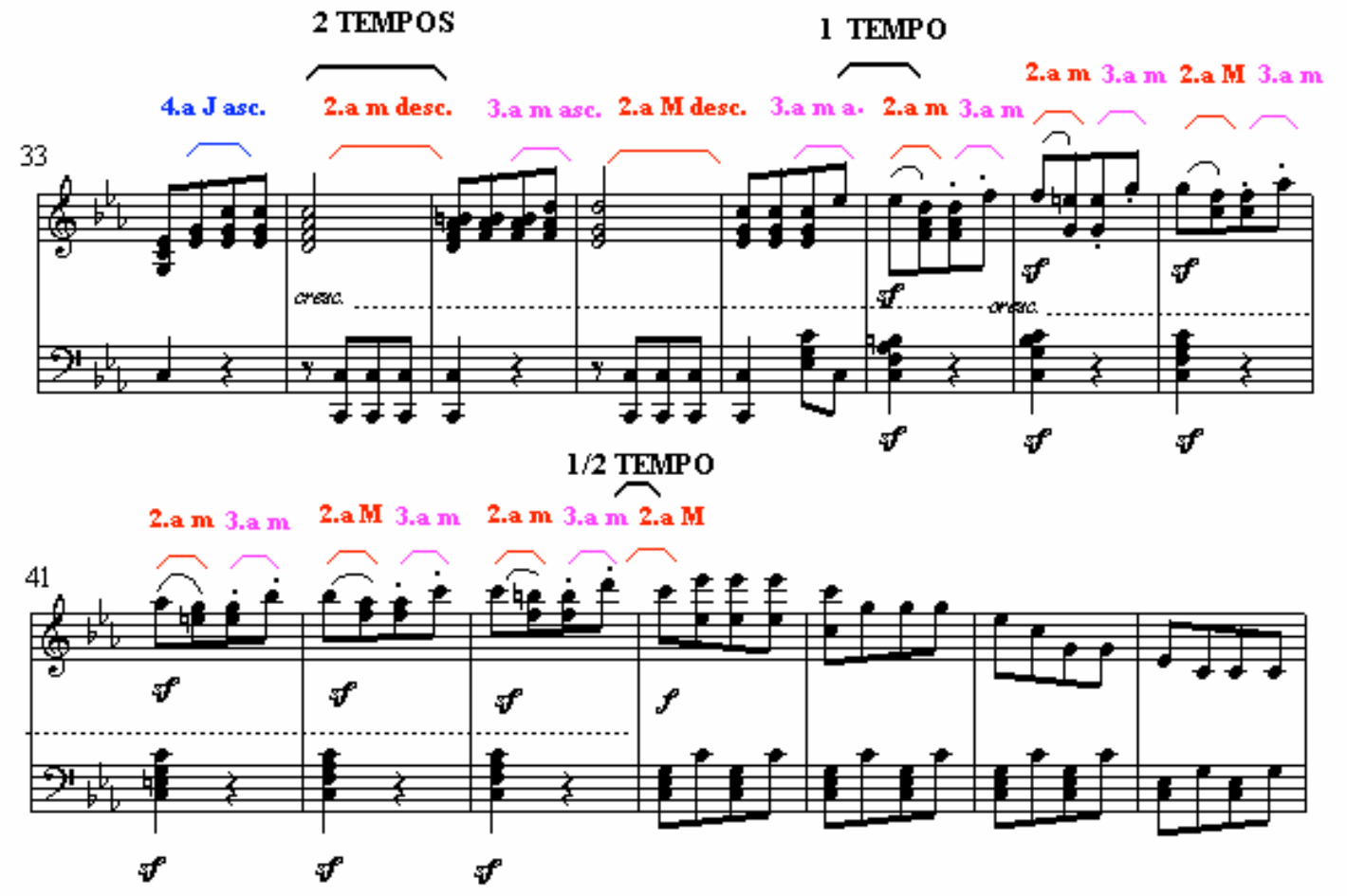

A progressão acima corresponde à manipulação do sujeito portador dos valores de extensão (discursivizado nesse caso pelo intervalo de 3.a) por um destinador portador de valores de intensão (intervalo de 2.a) que lhe transmite esses valores, transformado-o em seu portador. A contaminação do sujeito se dá pela exposição à intensão, numa progressão que começa com o intervalo portador dos valores de intensão (4.a) acompanhado pelo motivo rítmico inicial (intenso) seguido pela intensão do intervalo de 2.a, passando a partir daí a se alternarem intervalos de 3.a e 2.a. A intensão também se aspectualiza pelo crescendo dinâmico até o $\boldsymbol{f}$ (forte) e pela aceleração do período de alternância, que se inicia com 2 tempos e chega a $1 / 2$ tempo, terminando por impregnar o intervalo de 3.a e assim restaurar sua condição juntiva inicial. A partir do compasso 44, a continuidade do processo de intensão conduzirá à transformação de estado que constitui a própria razão de ser da ponte: a modulação. Passemos agora ao reconhecimento dos instrumentos utilizados pelo discurso para dar prosseguimento ao tensionamento. 

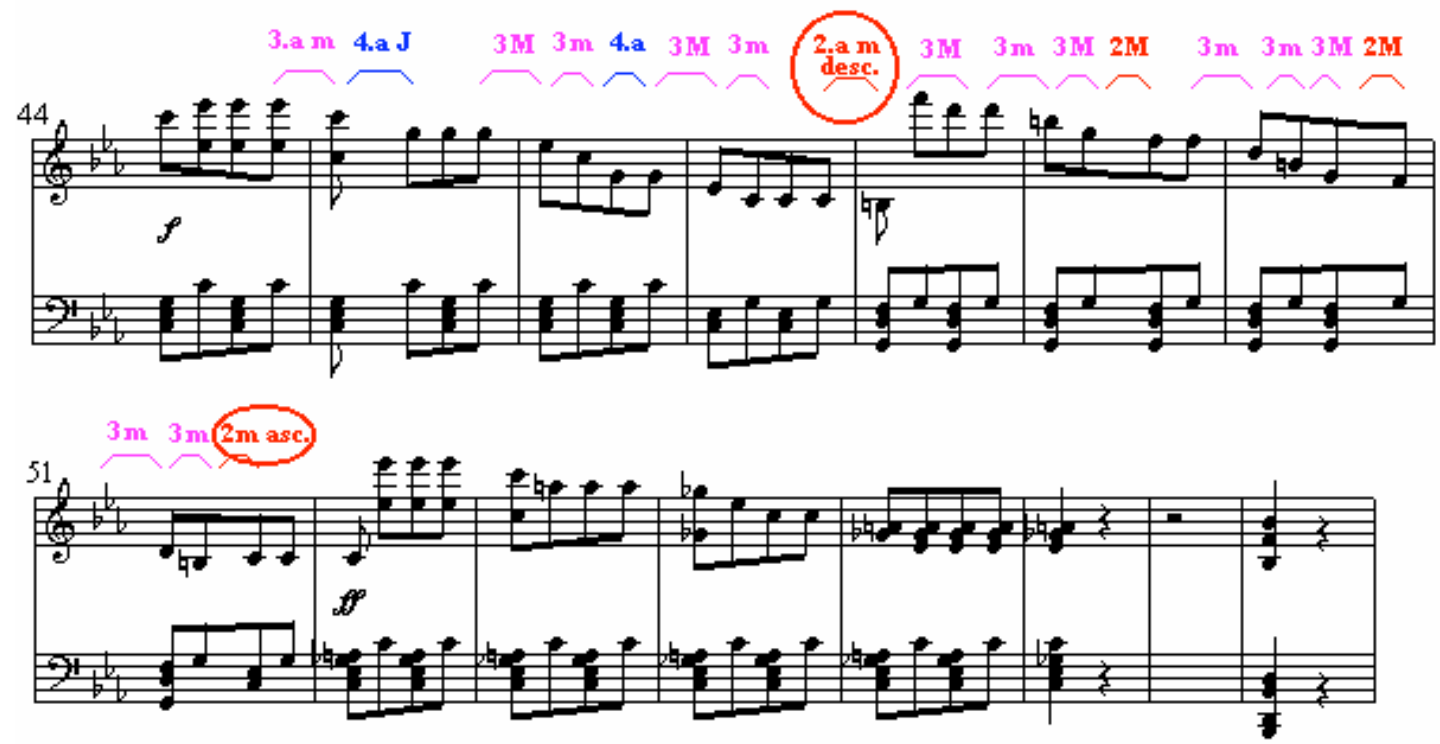

Tomando-se o trecho dos compassos 44 a 51, observamos que a progressão se organiza basicamente sobre terças, agora portadoras dos valores de intensão. Observe-se que a função da 4.a é novamente extensiva, expandindo o termo inicial na série de 3.as, e que o intervalo de 2.a menor aparece aqui claramente como elemento de pontuação desencadeando a cada aparição sua uma transformação melódica e harmônica. De fato, ocorrendo pela primeira vez, conduz a harmonia da tônica (repouso) à dominante (tensão); da segunda, introduz o conector isotópico (acorde diminuto de lá) entre as tonalidades de tônica (dó menor) e tônica relativa (mi bemol maior), elemento esse estranho à harmonia e, por isso, mais um fator de intensão, justamente aquele que desencadeará a transformação de estado. Note-se que os aspectos dinâmicos acompanham a intensão das demais instâncias do discurso, partindo do forte e alcançando clímax da região no fortíssimo do compasso 52. Por fim, como seria de se esperar, o excesso de intensão termina por acarretar a paralisação do discurso, que se fixa agora apenas no intervalo portador dos valores de máxima intensão (nesse caso específico, a 3.a menor) e, harmonicamente, no acorde de diminuta, que age como conector isotópico entre as duas tonalidades em questão, sendo um acorde da região de tônica na primeira tonalidade e da região de dominante na segunda (mais um fator de intensão). Finalmente, a paralisação se concretiza com a grande pausa (G.P. ${ }^{68}$, e a tensão se alivia com a resolução da diminuta, sendo que a transformação de estado harmônica é introduzida melodicamente através do agente de mutação do sistema, ou seja, pelo intervalo de 2.a menor, que, em dois movimentos ascendentes, promove a modulação tonal:

\footnotetext{
${ }^{68}$ Nome que se dá à pausa para todos os instrumentos da orquestra (n. do a.)
} 


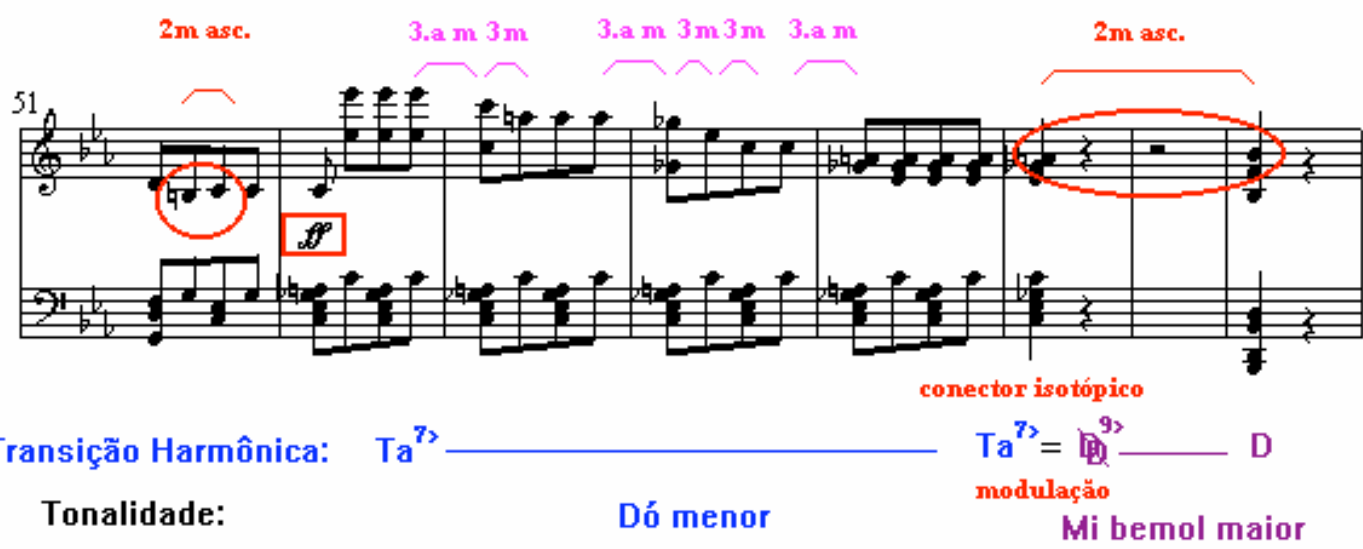

Atingida a nova tonalidade, segue-se a apresentação do II Tema, cuja análise comparativa em relação ao I Tema já foi realizada em item anterior deste trabalho. Pudemos desta vez, entretanto, acompanhar mais detalhadamente o fluxo de valores correspondente ao percurso narrativo coberto enquanto transição entre os dois materiais temáticos. Torna-se então previsível que à intensão crescente do trecho anterior, levando inclusive à suspensão do discurso, siga-se agora uma distensão que restabeleça o devir, privilegiando aspectos de continuidade e extensão. Recapitulemos o paralelismo entre os dois temas:
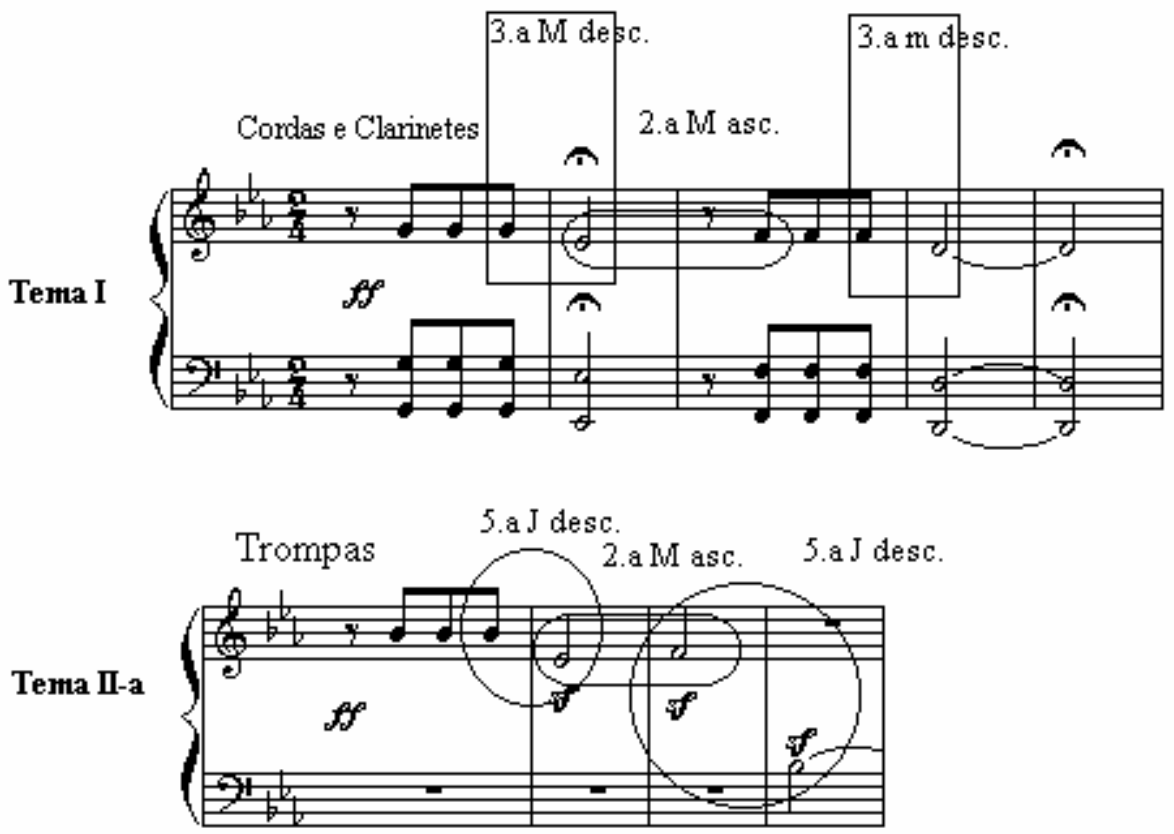

Já pudemos observar uma analogia entre a organização tensiva do I Tema enquanto microestrutura e o desenvolvimento do material temático que se lhe segue enquanto macroestrutura, e nomeamos concentricidade essa analogia entre os diversos níveis de organização do discurso, chamando ainda a atenção para uma abordagem da concentricidade enquanto manifestação no discurso musical do próprio modelo de percurso gerativo, à medida que se verifica que uma estrutura semântica 
profunda de natureza tensiva se converte na organização sintática da narrativa musical, gerando ordem e sentido na manifestação do discurso. Encontramos mais evidências disso ao reconhecer no movimento de extensão interna do I Tema a mesma gestualidade que distende o I Tema em direção ao II Tema. Acompanhemos mais detalhadamente pois o desenrolar deste último:

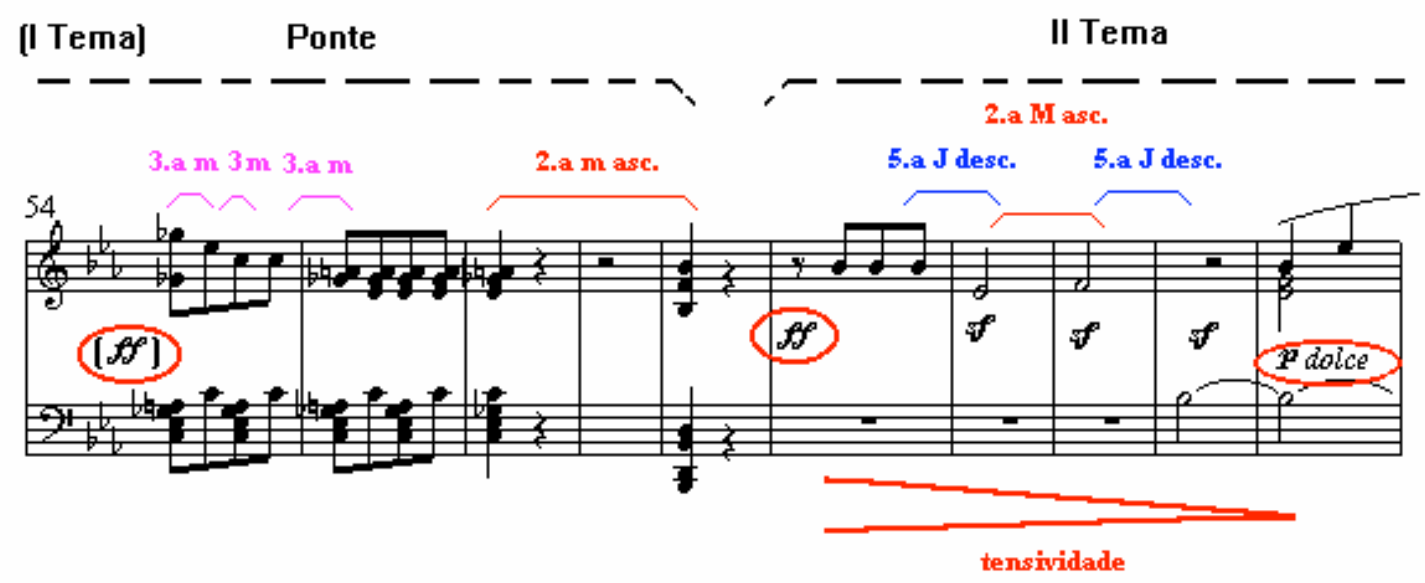

Partindo de uma configuração bastante tensa, manifestada dinamicamente pelo fortíssimo com que se inicia, a instância melódica nos apresenta um tema composto pela superposição de 5.as, ou seja, pelo portador dos valores de extensão, que vê sua aparição em sforzando se diluir em seguida em um piano dolce. É essa mesma diluição que transmuta o motivo anterior, que chamamos no princípio deste trabalho de II-a, no que se lhe segue, chamado II-b:

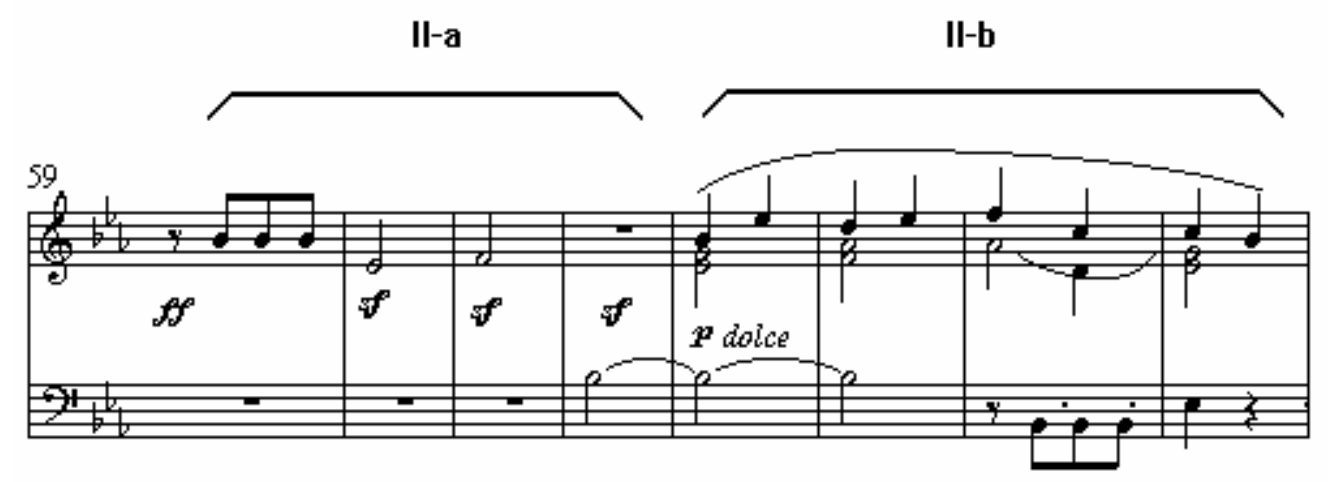

Além dos aspectos dinâmicos colocados anteriormente, releve-se também a questão da continuidade que se evidencia tanto ao confrontar o I Tema com II-a como ao se comparar II-a e a pontualidade de seus sforzandi com a grande ligadura que impõe um legato à articulação de II-b. Já no que tange à organização da estrutura intervalar da instância melódica, há importantes relações a serem consideradas. Examinemos a figura abaixo: 


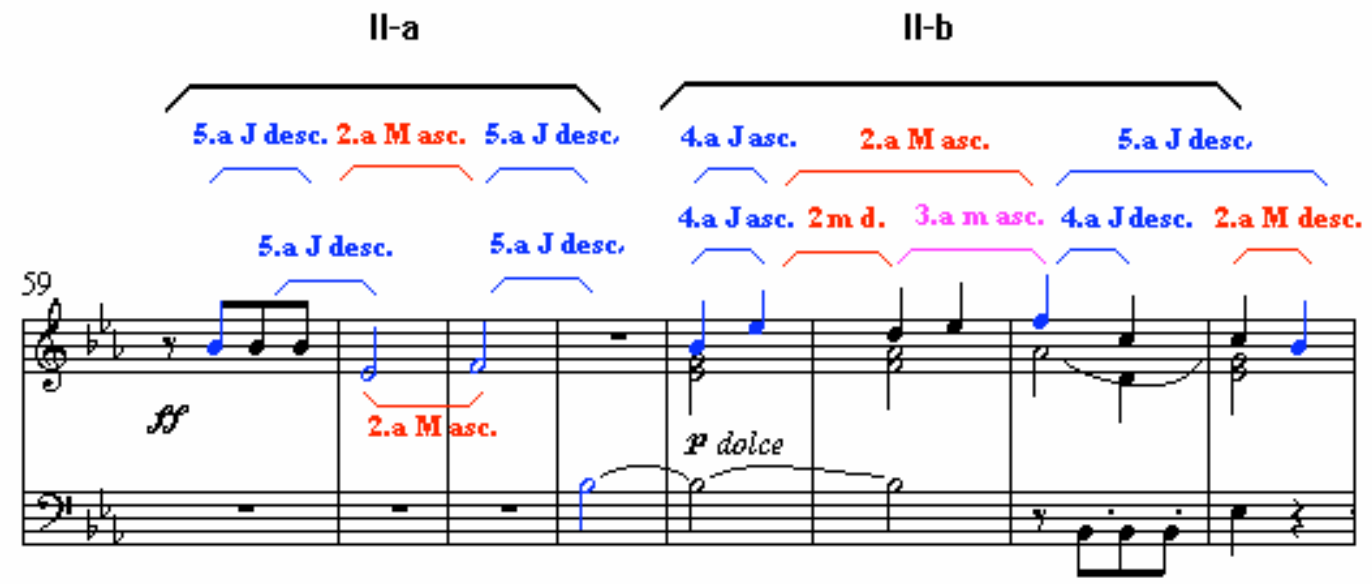

A análise intervalar torna evidente a analogia estrutural entre II-a e II-b. Interessa-nos agora determinar como a primeira configuração se transforma na segunda, o que equivale, determinadas como estão as estruturas actanciais, a investigar o trânsito de valores entre um estado e o outro. Ora, o próprio diagrama nos elucida que, salvaguardada a inversão do primeiro intervalo, II-b simplesmente equivaleria a II-a caso seus intervalos constituintes estivessem apresentados sintética, e não analiticamente. Entretanto, a exposição analítica por si só já sugere um processo de extensão, o que vem de encontro à nossa afirmação anterior. Mas é preciso enfatizar agora o grande diferencial entre a abordagem tradicional da teoria musical e aquela que propomos aqui. Não se trata simplesmente de identificar os elementos componentes do discurso e reconhecer uma variação macroestrutural enquanto articulação de suas microestruturas. Trata-se sim de constatar que cada unidade estrutural é dotada pelo discurso de um valor, de uma perspectiva semântica. Tal se evidencia pela arquitetura que relaciona II-a com II-b. Ambos são constituídos tensivamente por uma pulsação composta por extensão-intensão-distensão. Os movimentos de expansão são construídos a partir dos portadores de valores de extensão, e os de contração, pelos portadores dos valores de intensão. A apresentação em II-b da silabação extensão-intensão-distensão sob a forma analítica corrobora essa afirmação. Senão, vejamos:

A intensão aparece em II-a apresentada pelo intervalo de 5.a descendente; em II-b, pelo de 4.a ascendente. O fato de tratar-se de uma inversão nos permite ver em ambos uma equivalência que nos possibilita atribuir-lhes, nesse texto, o mesmo valor, conforme discutido anteriormente. Vejamos agora o movimento de contração. Em II-a, essa decorre da presença do portador secundário de valores de intensão (e também agente de mutação), o intervalo de 2.a. Em II-b, vemos o mesmo movimento articulado em outro intervalo de 2.a e um intervalo escalar de 3.a menor. Esse último constitui o representante principal dos valores de intensão do sistema. Vemo-los aqui ambos reunidos em última análise numa extensivização de seu correspondente em II-a, gerados novamente por uma relação de concentricidade como aquelas já vistas anteriormente. Finalmente, a distensão em II-b, se apresenta um elemento de intensão no intervalo de 2.a, tem por componente e por resultante o portador dos valores de extensão, prevalecendo dessa forma seu movimento de expansão. 
Acrescido mais esse dado para a compreensão da lógica do processo de geração de sentido no discurso musical, falta-nos muito pouco agora para cobrirmos a lacuna deixada pela teoria musical ao apresentar-nos a forma sonata como uma estrutura que consta de determinados elementos, cada qual genericamente dotado de uma função própria, sem entretanto estabelecer como esses elementos se relacionam entre si, qual sua conexão e de que maneira ocorre a transição entre cada sessão. A resposta a essas questões requer uma visão semiótica do discurso musical, que passa a ser entendido como um fluxo tensivo convertido à condição de trânsito de valores do sistema em relação juntiva com seus actantes e assumido por conversão e convocação aspectual por seus componentes discursivos. Vejamos resumidamente agora, para encerrarmos a análise da sessão de exposição da forma sonata, o restante da apresentação do II Tema e a codeta. A partir do compasso 59, temos:

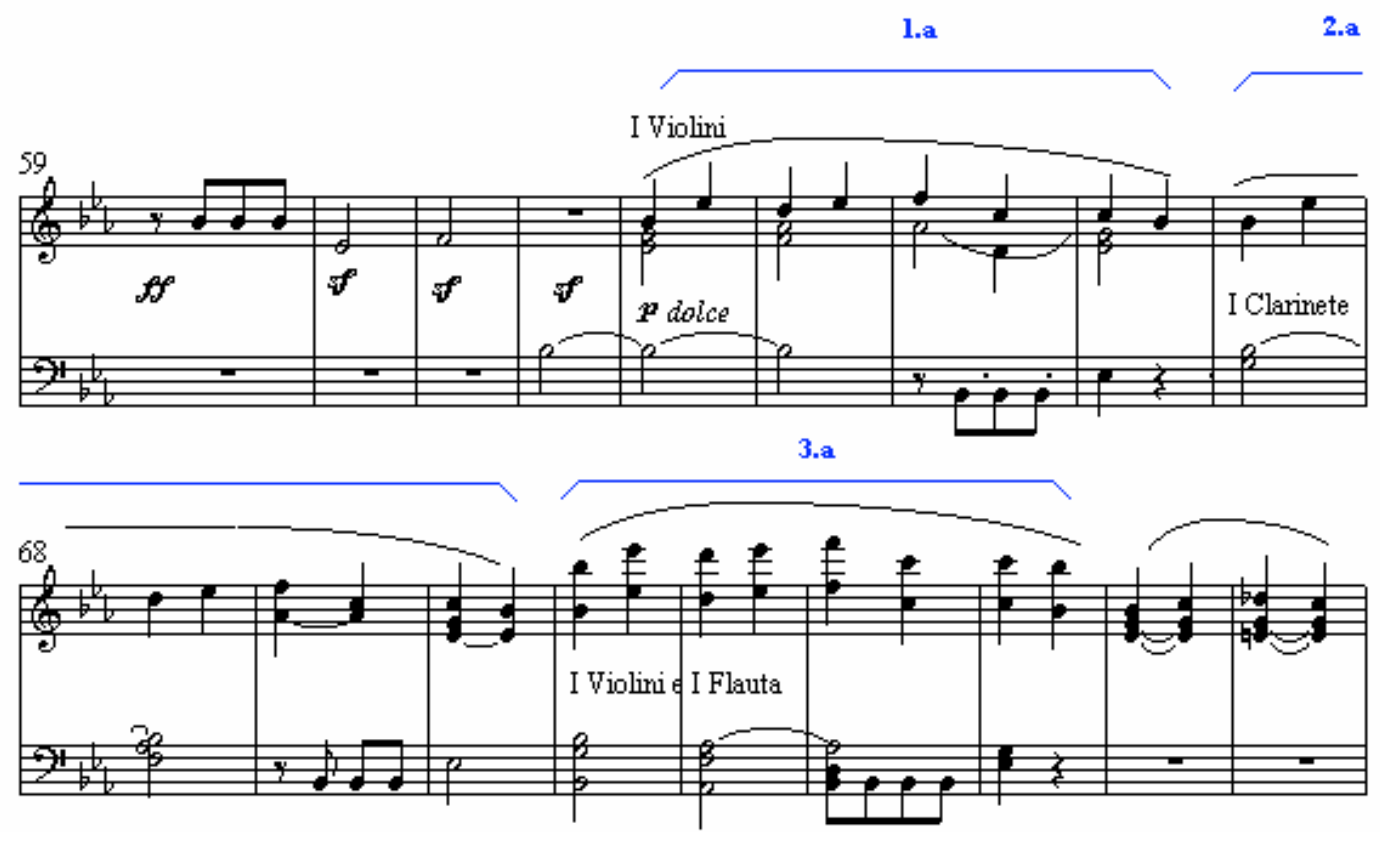

Vemos que a estrutura II-b se repete num total de três apresentações, cada qual com orquestração diferente, continuando assim sua diluição agora ao longo da instância timbrística, espargindo-se em oitavas entre flauta e violinos. Em seguida, passa-se a desenvolver o elemento de intensão de II-b:

II-b

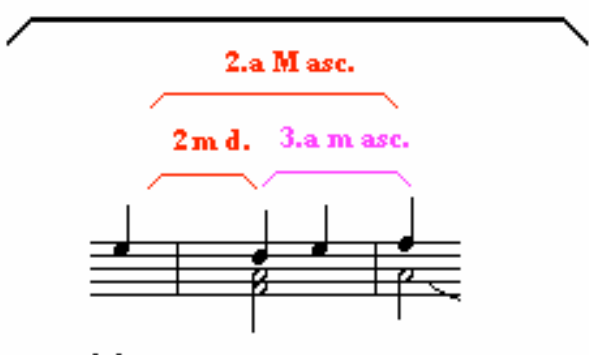

$\boldsymbol{p}$ dolce

O retrógrado de: 


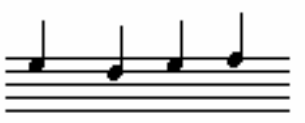

é:

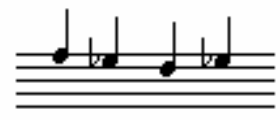

cujo inverso é:

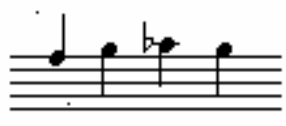

Assim,

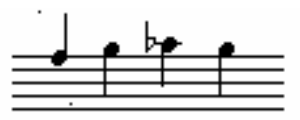

deriva de

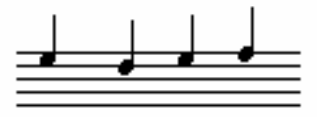

por

retrogradação e inversão. Enfim, por transposição, chegamos ao material temático que chamaremos de II-i:

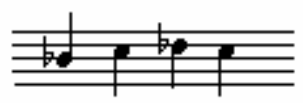

Por se tratar de uma derivação daquele núcleo de intensão de II-b, o material acima possui portanto também valor de intensão no trecho seguinte, em que aparece na forma acima como antecedente, da mesma maneira que a transposição de seu retrógrado, que chamaremos de II-i':

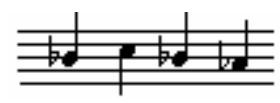

e que funciona como conseqüente do elemento anterior. 


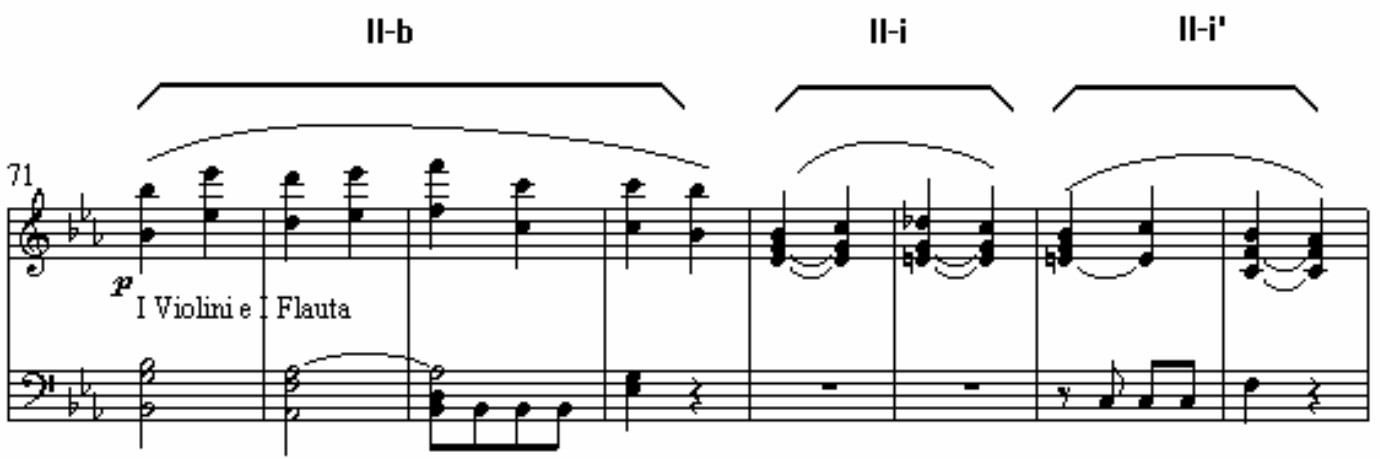

Pode-se então deduzir ser de intensão o percurso coberto entre os compassos 75 a 94 :

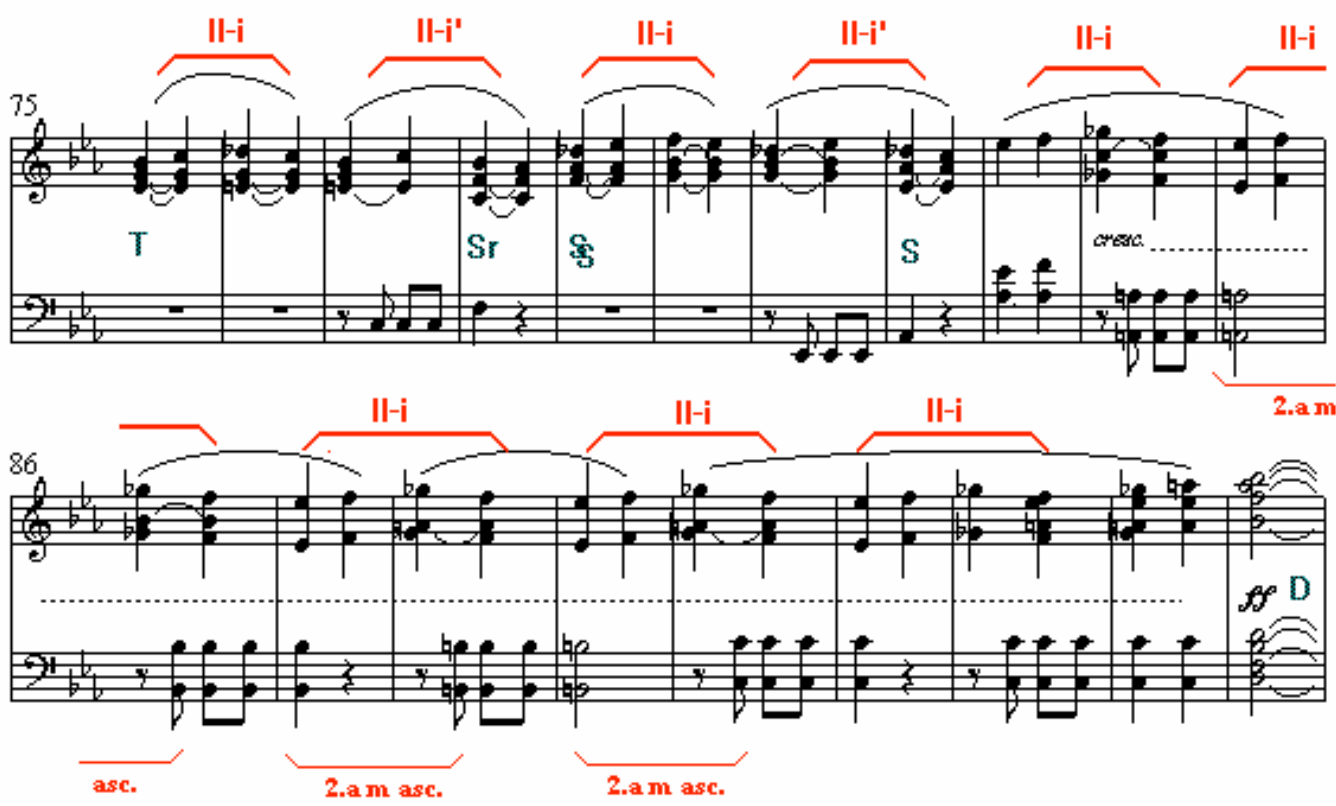

Além da construção sobre II-i, outros fatores discursivizam a intensão do percurso, quais sejam: o afastamento tonal resultante da progressão melódica e harmônica, que percorre da região da tônica àquela da subdominante e, dessa última, à de dominante, essa última constituindo a expressão direta da tensão na instância harmônica do discurso; a incidência, a partir do compasso 84, de uma progressão em 2.as menores ascendentes, cuja função enquanto elemento secundário de intensão e agente de mutação pode ser novamente sublinhada ao se constatar que é precisamente essa progressão que, paralisada a melodia em II-i, tensiona a harmonia da região de subdominante àquela de dominante, resultando finalmente na paralisação do discurso em 94 e à mudança de estado associada a esse evento e à introdução do próximo material temático, a partir do compasso 95; o próprio crescendo dinâmico, que conduz do piano anterior ao compasso 75 ao fortíssimo do compasso 94.

Tendo o percurso anterior sido derivado do antecedente II-i, a lógica da concentricidade se faz mais uma vez confirmar ao constatarmos uma relação entre o material temático seguinte e o conseqüente II-i': 


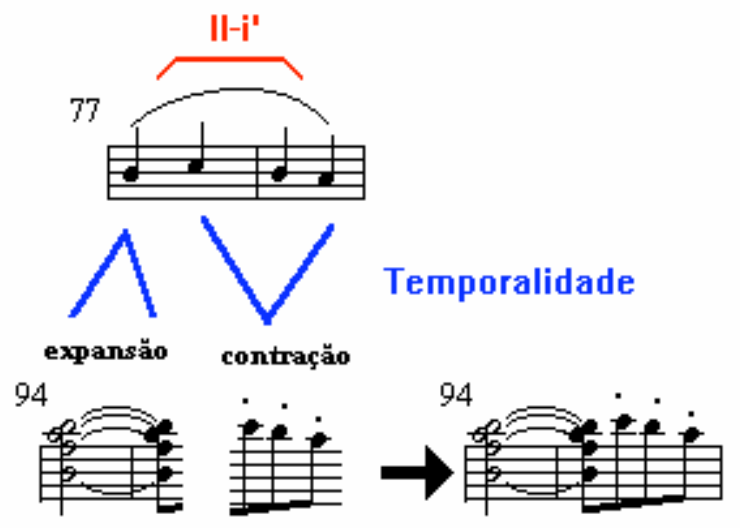

101:

Vejamos pois a estrutura intervalar do trecho entre os compassos 94 e

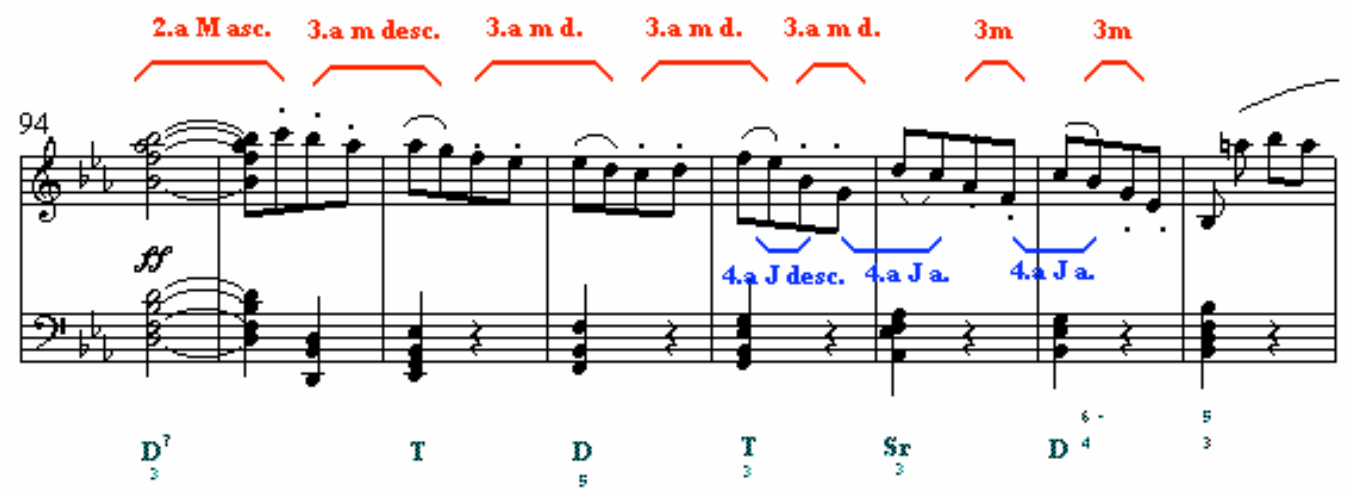

Observamos, quanto aos compassos 94 e 95, que a expansão temporal inicial de II-i' é compensada em seguida por uma aceleração. Pensando espacialmente, entretanto, o que temos é uma parada causada por excesso de intensão, seguida por uma distensão que conduz ao reencaminhamento do movimento melódico suspenso. A combinação desses dois fatores, no presente caso, resulta num trecho intenso em relação àquele da apresentação do II Tema (também pela presença das appogiature sobre os intervalos intensos de 2.a), e cuja movimentação corresponde a uma pulsação da forma tensão-distensão. Note-se que, na primeira metade do trecho, predominam os intervalos de 2.a e 3.a, associados à intensão, enquanto que a segunda metade apresenta uma presença crescente de intervalos de 4.a, associados à extensão, tratando-se assim de uma discursivização do quadro tensivo do motivo derivado de IIi'. Note-se ainda que a introdução dos elementos de extensão teve como conseqüência harmônica o afastamento da tônica rumo à região de subdominante, confirmando o movimento de expansão. A parada da progressão ascendente do baixo, porém, conduz a novo tensionamento que se traduz no acorde de dominante e acarreta a repetição do mesmo ciclo dos compassos 102 a 109: 

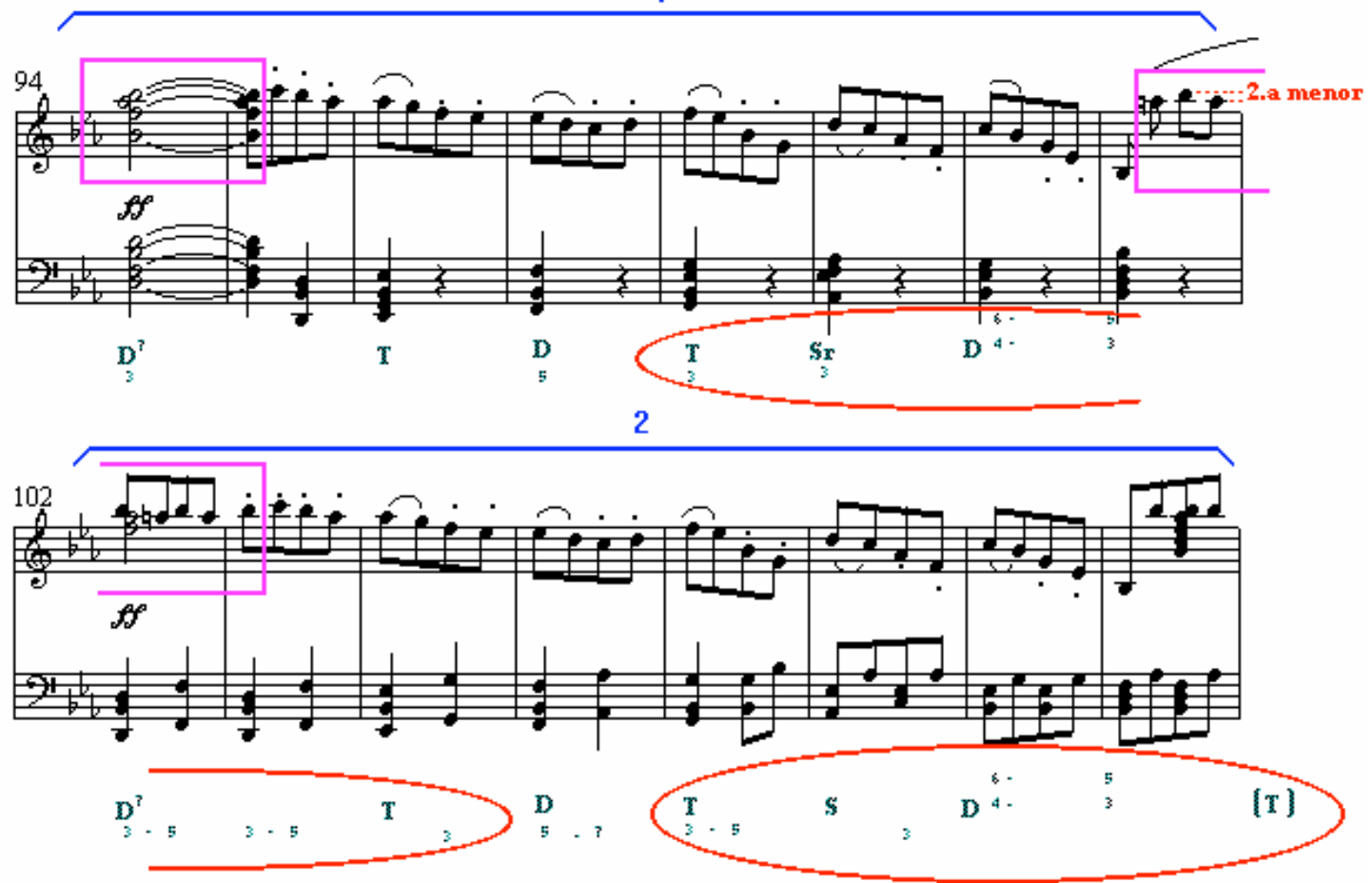

Observemos um ponto do maior interesse para a confirmação das hipóteses defendidas neste trabalho. De que maneira se efetua a correspondência entre os compassos 94 e 102? A teoria musical atual não teria elementos para justificar a substituição do acorde pela repetição do intervalo de 2.a menor, alegando provavelmente tratar-se de uma mera ornamentação. A semiótica, entretanto, nos mostrou que esse intervalo assume nesse discurso uma função relacionada a seu valor semântico. De fato, a substituição se deu entre um elemento de intensão local e um dos intervalos que assumem os valores de intensão do sistema. Trata-se portanto de uma substituição que segue rigorosamente o sistema de valores proposto pelo discurso, reafirmando sua organização sintática e semântica e a própria coerência do texto analisado. Em verdade, todo o extenso trabalho de análise dessa sinfonia realizado até agora passa a se justificar plenamente a partir desse ponto, onde verificamos que :

a) os valores assumidos pelo discurso logo nos primeiros compassos apresentam uma validade que não se restringe ao local, abrangendo sim a sua totalidade;

b) esses valores são intercambiáveis entre si, e a economia resultante é responsável pelo fluxo narrativo;

c) a mesma sintaxe narrativa permite diferentes discursivizações, desde que respeitada a lógica de conversão sujeito-ator, valor-tematização estabelecida pelo próprio sistema.

Continuando nossa abordagem do trecho acima, observemos também que a pontualidade da primeira apresentação gradualmente dá lugar à cursividade da segunda, substituindo-se os ataques incisivos no primeiro tempo de cada compasso por uma progressão de semínimas. Note-se ainda que a cadência esboçada em $\mathbf{1}$ (assinalada por uma elipse) não chega a se consumar plenamente, quer pela insistência na última dominante (compasso 102), quer pela resolução numa inversão da tônica, o que é outro fator que contribui para a repetição, a circularidade do segmento, cuja 
tensão cadencial só se resolverá no compasso 110 , onde entramos finalmente na codeta da exposição:

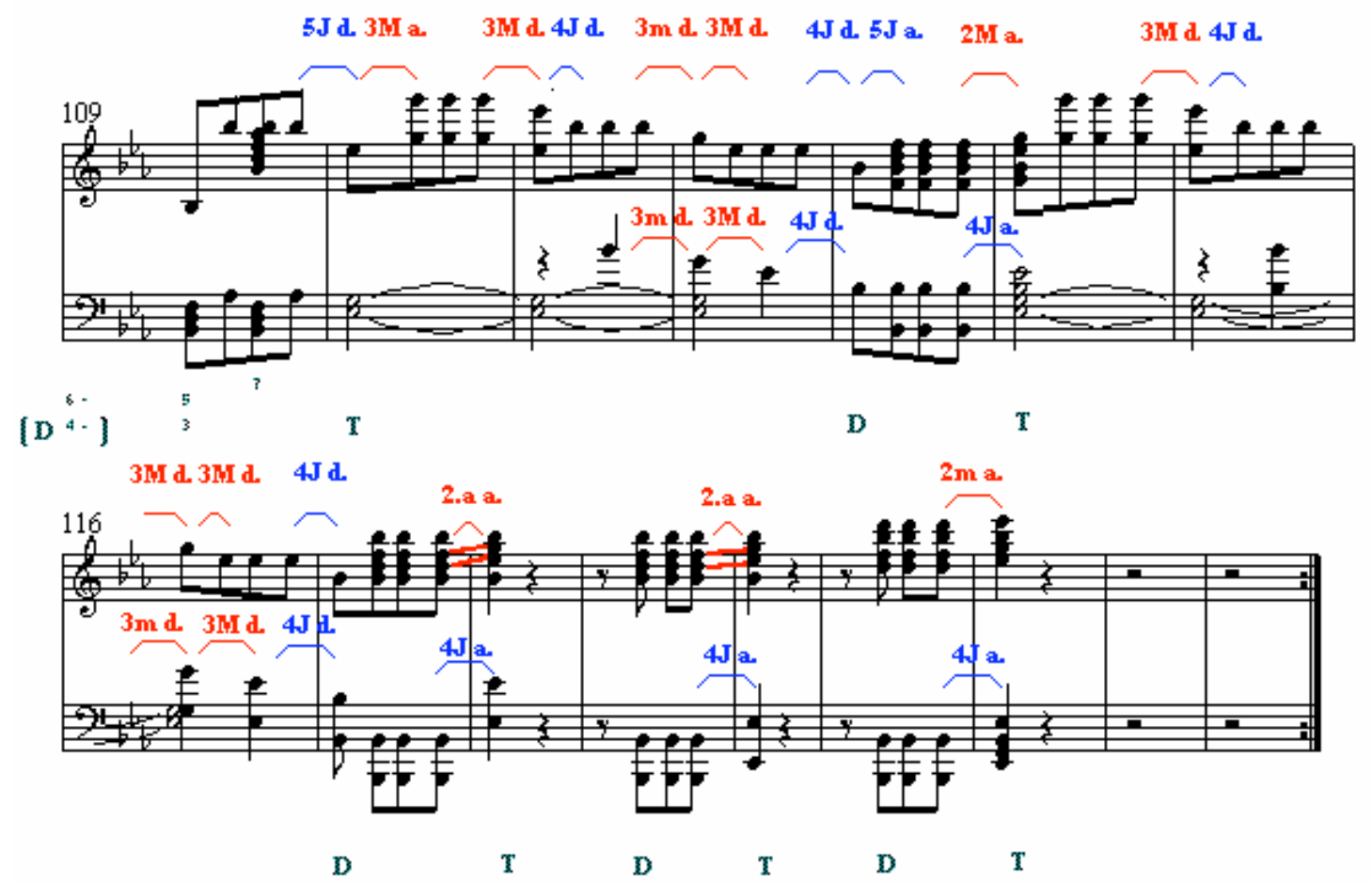

O percurso da pontualidadeldescontinuidade à cursividadelcontinuidade iniciado no trecho anterior se completa no compasso 110, quando a duratividade se estabelece através das notas longas de seis tempos. A expansão temporal (mínimas ligadas) e espacial (pelo uso do harpejo e sua distribuição orquestral) discursivizam a extensividade que ingressa no discurso com a incidência do intervalo de $5 . \mathrm{a}$ descendente. $\mathrm{O}$ elemento intenso está presente nos intervalos de 3.a, mas a tendência à concentração/pontualidade/descontinuidade é revertida pela ação do elemento extenso (4.as e 5.as) até o compasso 118, onde a ação dos intervalos de 2.a conduz à intensão até provocar a suspensão do discurso, a parada, a partir do compasso 122. Podemos daí inferir um percurso rumo à continuidade/extensividade que apresenta uma abertura gradual do compasso 102 ao 118, e um fechamento que reconduz à pontualidade/intensividade que termina nos compassos 122-124.

Notemos que o material temático derivado de II-i prevaleceu no discurso desde a aparição do II Tema até o compasso 110, onde as terças recuperam o material rítmico-melódico do I Tema. A codeta, cuja função é encerrar a exposição, cumpre seu papel exatamente pela recuperação de um percurso temático cuja abrangência cobre a sessão como um todo, e não meramente um ponto específico do discurso. Veja-se por exemplo o trecho entre os compassos 94 e 109. Apesar de apresentar uma função terminativa em relação ao II Tema, não pode ser considerado ainda como uma codeta pelo fato de seu material melódico não se estender por um percurso temático maior. Sendo o material II-i, como vimos, de certa forma derivado daquele do Tema I, há uma subordinação pois da especificidade em relação à matriz geradora, o que equivale a dizer que a terminatividade da codeta faz mister uma remissão ao percurso temático principal do discurso. No caso da codeta, a 
transformação de estado que marca seu princípio é a passagem da descontinuidade à continuidade, alcançada a partir da discursivização dos valores de extensão.

Pudemos ver assim por meio dessa análise da exposição do I movimento da 5.a Sinfonia de Beethoven de que maneira a teoria semiótica pode contribuir para a análise musical, cobrindo lacunas deixadas pela teoria musical no que tange à compreensão do processo de transformação e variação de motivos rítmicomelódicos que constitui a própria dimensão narrativa do discurso musical. Ao mesmo tempo, esperamos estar confirmando a abrangência do modelo greimasiano de percurso gerativo de sentido para a pesquisa de textos musicais e, ao mesmo tempo, estabelecendo algumas das bases metodológicas necessárias para a aplicação do modelo em textos dessa natureza. Por fim, com base na análise de uma obra mais extensa e que constitui um dos pilares de todo o repertório ocidental, pudemos mais uma vez confirmar nossa concepção do texto musical enquanto estrutura e sistema de valores, endossando nossa hipótese inicial de que a imersão e o aprofundamento que requer uma abordagem semiótica do discurso musical em seus primeiros passos não inviabiliza a análise de uma obra de maiores dimensões, à medida que a inicialmente trabalhosa identificação de seu sistema de valores, uma vez feita, agiliza sobremaneira o restante do percurso analítico. De fato, a cada nova conclusão, o analista se vê armado de um instrumento a mais para acelerar sua investigação, permitindo vôos cada vez mais longos, o que é extremamente positivo à medida que são justamente os textos de maior complexidade estrutural que naturalmente mais despertam o interesse e a curiosidade do pesquisador.

Estabelecida assim uma metodologia de abordagem e investigação da sintaxe narrativa do discurso musical, focalizando a dinâmica da transformação dos estados de coisas a partir da alteração de estado juntivo entre sujeitos e valores do sistema, passemos, finalmente, ao estudo da semântica narrativa, ou seja, da transformação dos estados de alma, compreendidos enquanto configuração modal associada a um dado sujeito de estado. Vamos pois, em outras palavras, ao estudo da paixão no discurso musical. 


\subsubsection{Semântica narrativa: a paixão no discurso musical}

a. Da modulação à modalização: categorização e aspectualização

Assim, a hesitação, que remeteria a uma modulação ao mesmo tempo de abertura e suspensiva, permitiria prever um avatar complexo do querer (querer e nãoquerer) e incitaria a buscar eventuais traços específicos na manifestação discursiva...essa metodologia da descoberta é a mesma que utilizam, intuitivamente ou com outros instrumentos de investigação, os psiquiatras, quando inferem a partir da forma aspectual e superficial de um comportamento... uma disposição psíquica de tipo modal e passional... As três instâncias - modulação, modalização e aspectualização, distribuídas respectivamente sobre a tensividade fórica, o nível semio-narrativo e a manifestação discursiva propriamente dita - constituem de algum modo o triângulo teórico cujo valor heurístico nos esforçamos por mostrar.

Greimas e Fontanille, Semiótica das paixões ${ }^{163}$
$\mathrm{O}$ enunciado supracitado deixa claro o equilíbrio entre modulação, modalização e aspectualização na gênese dos efeitos de sentido passionais. Tal colocação se faz necessária à medida que a evolução da teoria semiótica caminhou rumo ao equacionamento modal das paixões, extremamente prático para a abordagem de textos verbais, mas de eficácia bastante discutível enquanto ponto de partida para uma análise do discurso musical. Nesse caso, por onde iniciar um estudo das estruturas passionais no texto musical? A resposta nos é sugerida por Hanslick, em seu The beautiful in music:

What part of the feelings, then, can music represent, if not the subject involved in them? Only their dynamic properties. It may reproduce the motion accompanying physical action, according to its momentum: speed, slowness, strength, weakness, increasing and decreasing intensity... This is the element which music has in common with our emotions, and which, with creative power, it contrives to exhibit in an endless variety of forms and contrasts $^{164}$.

Assim, privilegiam-se no percurso gerativo dos efeitos passionais da linguagem musical os mecanismos de modulação e aspectualização, relegando-se a modalização a um enfoque secundário.

Ponhamos esse procedimento em discussão.

A Semiótica das paixões apresenta a modalização como uma categorização das modulações do devir aspectualizadas em incoativas, cursivas, terminativas e pontualizantes. Assim, a modalização surgiria, em última análise, da discretização resultante dessa aspectualização convertida à instância das estruturas semio-narrativas ${ }^{165}$. Tal procedimento é, em seguida, lexicalizado como querer, poder, saber e dever.

Evidencia-se assim ser a modalização uma construção teórica $a$ posteriore da sensibilização tanto no que tange às modulações do devir quanto às aspectualizações discursivas. Legitima-se portanto imediatamente uma consideração mais tardia da sintaxe modal, tendo-se em vista uma priorização dos dois outros braços do triângulo teórico. Nas palavras do próprio Greimas,

\footnotetext{
${ }^{163}$ Greimas \& Fontanille, 1993: 37

${ }^{164}$ Hanslick, 1974: 37-38

${ }^{165}$ Greimas \& Fontanille, 1993: 34-38; 41-42
} 
na ausência de manifestação direta ou indireta das modalizações, a observação das escolhas aspectuais dominantes permite postular a existência desta ou daquela modulação dominante no nível profundo, que teria sido convocada prioritariamente para a discursivização; suposta essa modulação como predominante, pode-se então suspeitar e prever que a organização modal, se houver uma em imanência, deveria estar afetada ou orientada. ${ }^{166}$

Justificado, pois, tal procedimento, verifiquemos agora seu mérito.

Pelas próprias qualidades intrínsecas ao seu plano de expressão, as modulações e aspectualizações apresentam-se no discurso musical com uma concretude tal que nos permitem, e até mesmo requerem, sua consideração enquanto pontos de partida de uma abordagem dos efeitos passionais. Já a detecção de elementos semelhantes às modalidades se apresenta como uma abstração, uma construção teórica a ser justificada a partir ou da evidência de seus efeitos de sentido ou da sintaxe resultante da discretização e aspectualização modulatória do discurso.

$\mathrm{Na}$ linguagem verbal, porém, tal quadro não raro se inverte: as modalizações são concretamente detectáveis no discurso, seguidas pelas aspectualizações convocadas ao nível discursivo, restando as modulações como instância final de abordagem, por vezes vindo à tona apenas por dedução a partir das transformações das configurações modais ao longo do percurso narrativo. Os conceitos de desejo, potência, conhecimento e dever ramificam-se em estruturas verbais que permeiam nitidamente a construção de sentido de um texto literário, tornando-se de tal forma mais prático operá-los que se justifica não só tomá-los como ponto de partida quanto ainda assumir e considerar todo o equacionamento modal desenvolvido até o presente, por se tratar de um elemento concretamente abordável para o discurso verbal.

Fica claro portanto que o que se propõe neste ponto do trabalho constitui em última instância uma alternativa metodológica, e não conceitual, em relação à atual práxis semiótica, divergindo os procedimentos em função de especificidades no plano da expressão das linguagens em questão. É a partir desse enfoque que se vislumbra uma possível contribuição ao corpus teórico semiótico resultante da extensão do modelo greimasiano aos sistemas semi-simbólicos, dado que a complementaridade da concretude-diafaneidade dos mecanismos de construção de sentido peculiares a cada sistema lingüístico permite vislumbrar e estudar instâncias diferentes do percurso gerativo, contribuindo quer para preencher as lacunas teóricas reconhecidas pelos próprios autores da Semiótica das paixões ${ }^{167}$, quer para ilustrar aspectos do modelo teórico pouco visíveis num dado código que se tornam evidentes quando aplicados em outro.

\footnotetext{
${ }^{166}$ Idem, p.37-37

${ }^{167}$ Ibid., p. 243

* Rosetta, pedra de: laje basáltica coberta de inscrições, descoberta em 1799, que constituiu a chave para que se decifrassem os hieróglifos egípcios. A pedra, encontrada perto de Rosetta, no Egito, tem 1,2 m de comprimento por $0,75 \mathrm{~m}$ de largura e apresenta textos idênticos em grego, demótico e hieróglifos.

(in Dicionário enciclopédico ilustrado tudo, vol. 3 pg.1100. 1977, São Paulo, Círculo do Livro)
} 


\author{
b. A pedra de Rosetta* : o caso da Sinfonia n.o 4 de \\ Tchaikovsky \\ Vous me demandez si cette Symphonie a un programme déterminé. \\ D'habitude, quand on me pose cette question au sujet d'une oeuvre \\ symphonique, je réponds: il n'y en a aucun!... Mais notre Symphonie \\ a un programme, autrement dit il est possible de raconter en paroles \\ ce qu'elle tente d'exprimer, et c'est à vous, à vous seule, que je peux \\ et que je veux dire ce qu'elle signifie...
}

Tchaikovsky, carta à Baronesa Von Meck, 17 de fevereiro de
$1878^{168169}$

Em carta a sua amiga e confidente Nadezhda Von Meck, Tchaikovsky propõe uma verbalização dos efeitos de sentido por ele criados em sua quarta sinfonia. O autor salienta não se tratar tecnicamente de uma obra programática, advindo sua leitura de sua profunda intimidade e compreensão do texto, não devendo, em hipótese alguma, ser publicada ou anexada à partitura.

Em todo caso, esse comentário é de grande interesse para nosso estudo, por se tratar da versão de maior legitimidade possível da música para a palavra. Procuraremos a partir dessa transposição intersemiótica reconhecer no texto musical os elementos responsáveis pela geração dos efeitos de sentido propostos pelo autor, aplicando e aprofundando assim a reflexão desenvolvida ao longo deste trabalho.

Não se devem esquecer, entretanto, as objeções levantadas por vários teóricos, insistindo na impossibilidade de intersecção entre os campos semânticos das duas linguagens em questão. Respeitadas tais ressalvas, vale acentuar que trata-se de uma aproximação, e não de uma tradução ipsis litteris, e que o que verdadeiramente nos importa é o sentido do texto, e não sua significação. Além disso, por mais que se alegue tratar-se de uma falácia ad verecundiam, vale citar o comentário de Wilson Coker em sua interessante obra Music \& meaning (em que se depara com a mesma questão por propor uma abordagem semiótica peirceana do discurso musical) em resposta à relutância de alguns críticos e estudiosos em aceitar as palavras dos próprios autores sobre suas obras:

Although it may seem a monstrous impertinence to presume that an artist such as Mozart and Tschaikovsky is an intellectual ass (sic.) who simply doesn't know what he does regardless of what he says he intends, many a critic hesitates not a whit to so presume ${ }^{170}$.

Consideremos agora os comentários de Tchaikovsky a respeito de sua 4.a sinfonia (escritos pelo autor originariamente em francês, língua que dominava e que utilizava habitualmente para se corresponder com seus amigos europeus), e busquemos

\footnotetext{
${ }^{168}$ Tchaikovsky, 1985:128

${ }^{169}$ Idem, p.128

${ }^{170}$ Coker, 1972: 146
} 
em seguida no texto musical os procedimentos discursivos responsáveis pela geração dos efeitos de sentido mencionados pelo autor. maîtresse ${ }^{171}$ :

L'introduction est le noyau de toute la symphonie, incontestablement son idée

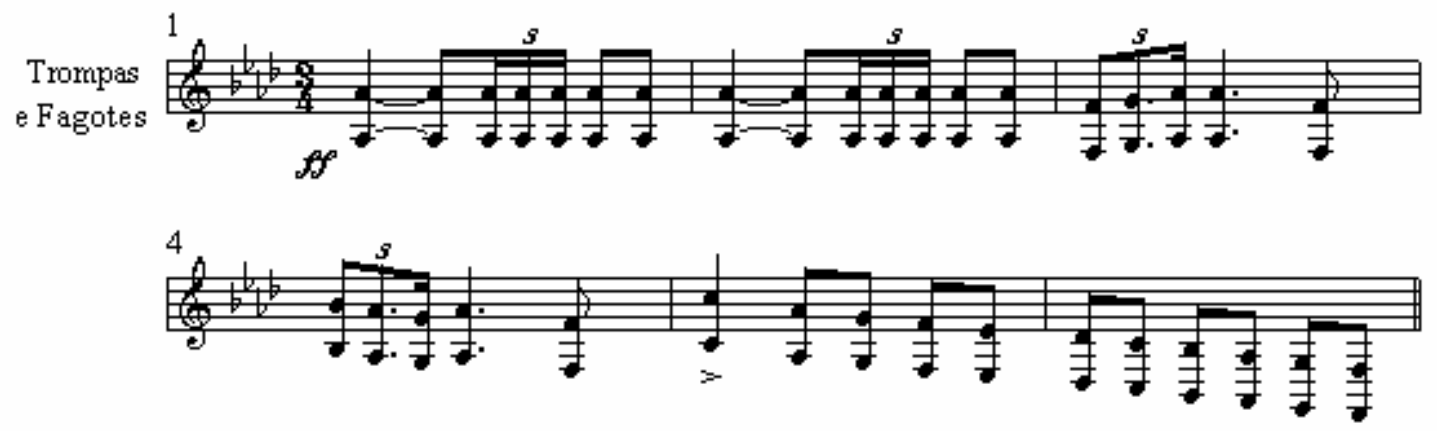

C'est le destin, cette force fatale qui empêche l'élan et le bonheur d'atteindre leur but, qui veille jalousement à ce que le repos et le bien-être ne soient pas complet et sans nuages, qui, telle une épée de Damoclès, est suspendue au-dessus de la tête des hommes et empoisonne leur âme. Elle est invincible, cette force, luttant contre elle, on ne peut jamais avoir le dessus ${ }^{172}$.

A afirmação da introdução enquanto núcleo e idéia condutora da sinfonia se sustenta na medida em que se verifica serem os demais motivos temáticos do discurso derivados dessa única estrutura por procedimentos de variação próprios da linguagem musical, procedimentos esses análogos àqueles já vistos em nossas análises anteriores e cujo detalhamento maior foge nesse momento aos objetivos deste trabalho.

Sob o ponto de vista semiótico, é importante aqui frisar constituir o trecho musical citado acima a primeira estrutura actancial a ser apresentada na sinfonia. Para distingui-la das demais estruturas que se seguirão, e para fugir a uma nomenclatura conceitualmente problemática*, chamá-la-emos, à parte de sua função narrativa, estrutura actorial 1. É através principalmente das aspectualizações que acompanham essa estrutura que poderemos estabelecer uma correspondência entre os textos verbal e musical de Tchaikovsky. Antes disso, porém, prossigamos com algumas considerações sobre as afirmações do autor, buscando isolar as estruturas aspectuais, modais e modulatórias geradoras dos efeitos de sentido passionais passíveis de conversão para o discurso musical.

Inicialmente, consideremos alguns termos utilizados no texto.

\footnotetext{
${ }^{171}$ As figuras, quando no corpo das citações, reproduzem ilustrações do próprio autor que constam do texto original da carta (n. do a.)

${ }^{172}$ Tchaikovsky, 1985: 128

* O termo ator não parece próprio, dada a maleabilidade do motivo musical (não estamos aqui tratando de intervalos, como nos casos anteriores) e sua extrema mutabilidade tensivo-fórica. Ator sugere algum grau de definição, estabilidade e fixidez, ao menos "corporal”, estranho à articulação discursiva musical. Também será evitado aqui o termo utilizado em teoria musical, tema, pois sua utilização nesse trabalho está condicionada à compatibilidade conceitual com o termo homônimo na teoria semiótica, compatibilidade essa que, nesse caso específico, é complexa, discutível e, uma vez assumida, poruco produtiva em termos de análise. Estrutura já parece permitir o grau de articulação usual dentro da linguagem musical, e actorial, respeitando a identidade de cada estrutura, abre espaço para a assunção das funções actanciais no nível narrativo. Tais peculiaridades ilustram mais uma vez a diferença de tratamento que requerem as linguagens verbal e musical quando abordadas sob um ponto de vista semiótico.
} 
Destin, segundo o Petit Robert, pode ser definido como:

1 - Puissance qui, selon certaines croyances, fixerait de façon irrévocable le cours des événements.

2 - Ensemble des événements contingents ou non qui composent la vie d'un être humain, considérés comme résultants de causes distinctes de sa volonté.

3 - Le cours de l'existence considéré comme pouvant être modifié par celui qui la vit ${ }^{173}$.

É mais do que relevante apontar que Tchaikovsky apresenta um destino sensibilizado e aspectualizado por um observador, além de caracterizar uma relação intersubjetiva em que um destinador destin impede um sujeito les hommes de estar em conjunção com uma série de valores apresentados como élan, bonheur, repos, bien-être. Como estariam dois sujeitos representados musicalmente por uma única estrutura actorial? Propõe-se aqui uma resposta tão simples quanto instigante, que nos sugere de um único golpe um percurso e um instrumental teórico valioso para nossa investigação, tanto no que tange aos mecanismos que regem a transposição intersemiótica em questão quanto ao próprio estudo da paixão no discurso musical. Senão, vejamos.

A estrutura actorial 1 pode estar representando musicalmente não um sujeito isolado, mas uma relação, correspondendo mais precisamente ao actante destin aspectualizado por um observador les hommes. Ora, o efeito de sentido da realização de uma descrição por um observador constitui um simulacro discursivo da própria enunciação, de onde se poderia concluir, assumindo-se como hipótese uma analogia entre os planos do conteúdo dos dois textos e estabelecendo-se entre eles uma correspondência entre configurações actanciais, ser les hommes o correspondente verbal ao enunciador do discurso musical. Estando presente ainda o efeito de sentido de um enunciador descrevendo um outro sujeito, tem-se por conseguinte o equivalente a uma debreagem enunciva actancial, resultando num efeito de sentido de objetividade. Podese ir um pouco mais além nessa linha de raciocínio, propondo-se um efeito de sentido de impessoalidade, baseando-nos nas proposições de Benveniste a respeito da identificação conceitual da 3.a pessoa com uma não-pessoa ${ }^{174}$. Tal impessoalidade, aspectualizada por intensidade (indicação de fortíssimo na partitura), é passível de uma gama de moralizações em que pode passar a conotar desde indiferença até desumanidade. Mas, antes de ingressar no campo aspectual, cabe mais uma interrogação a respeito de nosso suposto sujeito enunciador: qual seria seu modo de existência?

Segundo a Semiótica das paixões, temos:

Apenas a potencialização seria suscetível de suportar o desdobramento passional, e isso por várias razões... a potencialização, que seria como uma suspensão obrigatória do programa narrativo entre a aquisição da competência e a performance, poderia ser definida como a operação pela qual o sujeito, qualificado para a ação, torna-se suscetível de representar-se fazendo, isto é, projetando em um simulacro toda a cena actancial e modal que caracteriza a paixão.. .175

Verifiquemos se o sujeito enunciador atende às condições impostas para ser classificado como sujeito potencializado. Para isso, passemos a estudar de que maneira os sujeitos les hommes e destin aparecem modalizados, valendo-nos do texto de Tchaikovsky e das definições propostas pelo Petit Robert pra alguns do termos utilizados naquele.

\footnotetext{
${ }^{173}$ Robert, 1994: 621

${ }^{174}$ Benveniste, 1966: 228

${ }^{175}$ Greimas \& Fontanille, 1993: 132-133
} 


\section{i. $\quad$ Configuração modal dos actantes no texto verbal}

Tomemos primeiramente o anti-sujeito destin. A primeira definição do Petit Robert citada no item anterior atualiza o anti-sujeito através de um poder-fazer, uma puissance. Muito interessante notar de que maneira se salienta o aspecto cursivo da modalidade, "fixando de maneira irrevogável o curso dos acontecimentos". Pode-se ainda ir um pouco mais além e depreender um esboço da dimensão fiduciária da relação intersubjetiva, realçada em "segundo algumas crenças". Nesse caso, haveria um pacto fiduciário onde les hommes crê em um poder-fazer atribuído ao anti-sujeito.

As "causas distintas de sua vontade" da 2.a definição associadas a um destino que "impede" a conjunção do sujeito com l'élan et le bonheur estabelecem les hommes enquanto sujeito que quer e não-pode estar em conjunção com os valores do discurso, polemizando com o anti-sujeito destin, responsável pela parada no percurso do fazer e pela instauração do percurso do ser, dos estados de alma. A conseqüência é o predomínio de um fazer remissivo em detrimento do fazer emissivo, da dimensão temporal sobre a espacial, do ser sobre o fazer, configurando-se passionalmente o discurso:

A instância da enunciação apresenta-se como poder de configuração complexa, oscilante, regulador rítmico, criador de tempo quando o fazer remissivo sobrevem, concentra, nominaliza e modaliza; criador de espaço quando o fazer emissivo advém, difunde, verbaliza e narrativiza. O eu aparece, no nível figural, como um lugar de intersecção e de arbitragem entre tempo e espaço: o tempo seria apenas a contenção do espaço enquanto que o espaço seria apenas o desdobramento do tempo ${ }^{176}$.

$\mathrm{O}$ aborto da performance de aquisição de valores de les hommes vem a constituir mais um elemento a apontar para a hipótese de um sujeito enunciador potencializado para o discurso musical, situando-se o percurso passional, como previsto, numa etapa entre a aquisição de competência e a performance que, nesse caso, não se concretiza.

A terceira definição fornecida pelo Petit Robert não encontra eco no trecho citado até agora, não sendo necessária no momento sua consideração. Nem necessária nem desejável, à medida que a remodalização dos sujeitos a que ela obrigaria alteraria sobremaneira o equacionamento modal proposto até agora, situação essa que Tchaikovsky habilmente reservou para um outro momento da sinfonia, gerando assim um percurso passional em torno de diferentes aspectos de uma mesma paixão.

A utilização do termo jalousement para moralizar e aspectualizar o estado patêmico do anti-sujeito não poderia ser mais feliz para um semioticista. Em seu estudo sobre o ciúme, Greimas estuda minuciosamente a composição dessa paixão, dando-nos uma série de referências para abordar o quadro descrito pelo mestre de São Petersburgo. Entretanto, a análise na Semiótica das paixões enfoca quase que exclusivamente o ponto de vista do ciumento, quando, em nosso caso, o observador é exatamente o outro, o rival, aquele que deve ser excluído. O pacto fiduciário, conforme nos permite o modelo greimasiano, existe nesse caso aparentemente à revelia do sujeito observador, que, movido por seu desejo de conjunção, busca lograr seu intento. É assim, num primeiro momento, um sujeito do querer em relação ao objeto e de um não-saber em relação ao pacto fiduciário intersubjetivo que o relaciona ao anti-sujeito. Segue-se a polêmica, que é "vencida" pelo anti-sujeito, que faz $S_{1}$ passar de um estado de conjunção para um de

\footnotetext{
${ }^{176}$ Zilberberg, 1988: 104
} 
não-conjunção com o objeto (até o ponto em que o texto foi citado, não se pode falar em disjunção, que aparece logo em seguida de maneira muito nítida na continuação da carta. Por enquanto, a atuação do destino restringe-se a impedir l'élan et le bonheur d'atteindre leur but, a conjunção complet et sans nuages). $\mathrm{Na}$ etapa final, $\mathrm{S}_{1}$ reconhece $\mathrm{e}$ sanciona cognitivamente a vitória de $\mathrm{S}_{2}$, aspectualizando-a como durativa, permanente, o que reverterá numa permanência (aspectualização temporal) de seu estado de alma que trará desdobramentos passionais e narrativos ao discurso musical, estabelecendo-se nesse ponto o cerne do drama patêmico. O sujeito observador passa assim a percorrer os infinitos matizes aspectuais da resignação, e a narratividade do discurso se estabelece exatamente pela alternância entre os sucessivos estados de alma que o afetam. Em algum lugar do continuum que abarca a totalidade de possibilidades aspectuais, situa-se o complemento semântico capaz de definir a sanção cognitiva como positiva ou negativa, ou, melhor ainda, capaz de afirmar seu termo complexo pela própria possibilidade de percurso entre seus pólos.

Resta-nos ainda por analisar o episódio interdiscursivo do texto.

Junto ao verbete épée, encontramos no Petit Robert uma definição para a expressão épée de Damoclès:

Danger qui peut s'abattre sur qqn d'un moment à l'autre (par allus. à l'épée suspendue par un crin de cheval au-dessus de la tête de Damoclès) ${ }^{177}$.

Falta porém à explicação acima um aspecto do mito de Dâmocles que parece ser pertinente demais para ser deixado de lado numa consideração mais cuidadosa do texto, aspecto esse que certamente não seria estranho à vasta cultura de Tchaikovsky:

Dâmocles: cortesão de Dionísio, o Velho, tirano de Siracusa. Como invejava a vida faustosa de seu soberano, recebeu dele a promessa de substituí-lo por um dia. Durante um banquete, Dâmocles percebeu sobre sua cabeça uma grande espada suspensa por uma crina de cavalo e sentiu como eram precários os prazeres que cobiçava. A "espada de Dâmocles" passou a simbolizar a felicidade aparentemente perfeita, mas perturbada por uma ameaça latente (in: Dicionário enciclopédico ilustrado tudo, vol.1 pg.402. 1977, São Paulo, Círculo do Livro).

Assim, trata-se não apenas de um perigo que surge repentinamente em qualquer situação, mas, mais especificamente, da interrupção de uma cursividade eufórica. O mito detalha essa interrupção, associando-a a uma sanção cognitiva negativa por parte do próprio sujeito que estava em conjunção eufórica, caracterizando-se aí um percurso pelo qual aquele sofre uma manipulação por intimidação. A verticalidade da imagem de uma espada suspensa por um fio é patente, e sua incidência pontual sobre o curso do devir aspectualiza-se na própria definição da modalidade deôntica. Isso traz alterações substanciais ao quadro esboçado até agora.

A sanção cognitiva negativa que o sujeito observador assume de sua situação de conjunção com os valores discursivos gera um dever não-ser em relação a esse estado, alterando-se assim o equilíbrio do triângulo modulação-modalizaçãoaspectualização, configurador do equacionamento patêmico do discurso. Surge também a contradição entre um querer-ser que valoriza euforicamente um estado de coisas, a conjunção $\mathrm{S}_{1--\mathrm{O}}$, e um dever não-ser que o sanciona negativamente e, conseqüentemente, disforicamente. Redimensiona-se assim o conflito gerador do discurso mencionado parágrafos acima, possibilitando uma leitura mais clara de seu nível profundo, que passa a poder ser entendido enquanto conflito vida $\mathrm{x}$ morte, vida

${ }^{177}$ Robert, 1994: 792 
enquanto modulação de abertura, expressão do desejo e do querer, morte enquanto pontualidade, interrupção cursiva do devir modalizada por um dever.

É precisamente nesse conflito que reside o veneno que empoisonne leur âme aludido por Tchaikovsky, dando conta assim do último elemento textual que ainda escapara à nossa consideração. De fato, um exame do Petit Robert nos remete às seguintes acepções de empoisonner:

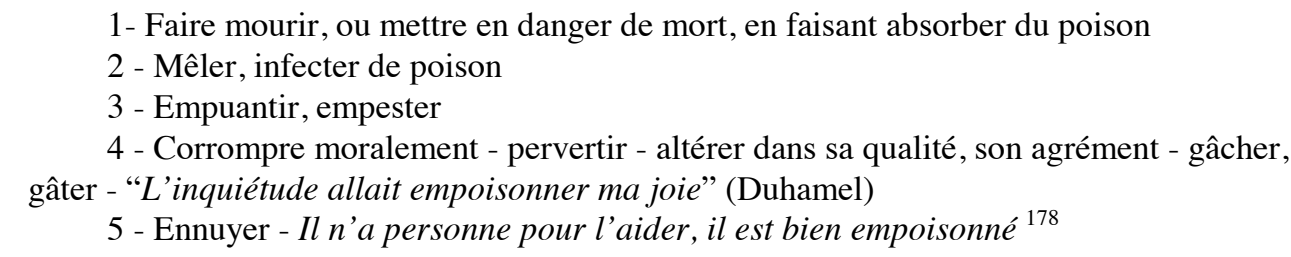

Interessam-nos nesse caso apenas as definições 1, 4 e 5. A primeira reforça a idéia de morte desenvolvida nos parágrafos anteriores. A quarta e a quinta salientam a transformação de estado patêmico resultante da conversão do sentido do percurso fórico rumo à disforia. Confirmam-se, por qualquer uma delas, as colocações feitas anteriormente.

Uma vez atingida uma visão panorâmica abarcando o equacionamento modal e outros mecanismos responsáveis pela geração de efeitos de sentido passional referentes à carta do compositor russo, voltemos a assumir uma correspondência entre os planos do conteúdo dos textos verbal e musical de Tchaikovsky, correspondência essa que, ainda que restrita apenas a um mínimo de mecanismos de geração de sentido necessário para o estabelecimento de uma analogia entre os estados patêmicos dos dois textos, parece já suficiente para ilustrar de que recursos discursivos o autor se vale para estabelecer os mesmos efeitos de sentido num outro plano lingüístico, elucidando nossa investigação a respeito dos instrumentos de que se vale o discurso musical para a construção de sua dimensão semântica narrativa. Passemos agora, pois, a uma consideração semiótica do texto musical citado, mais precisamente dos 26 primeiros compassos da Sinfonia n.o 4 de Tchaikovsky que constituem formalmente sua seção introdutória.

\section{ii. $\quad$ Recursos e mecanismos discursivos do texto musical}

Eis aqui o trecho da sinfonia a que se refere a primeira parte da carta:

\footnotetext{
${ }^{178}$ Robert, 1994: 748
} 
Andante sostenuto

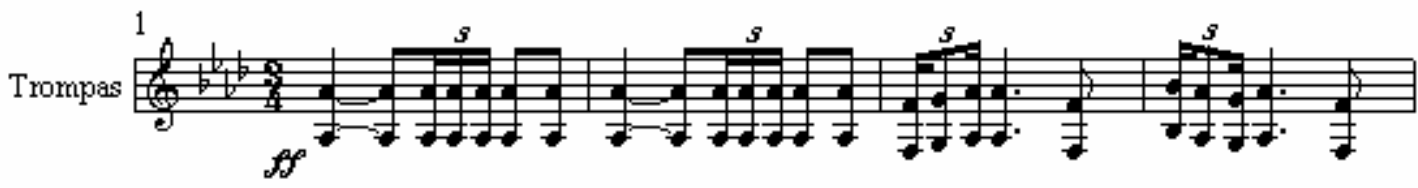
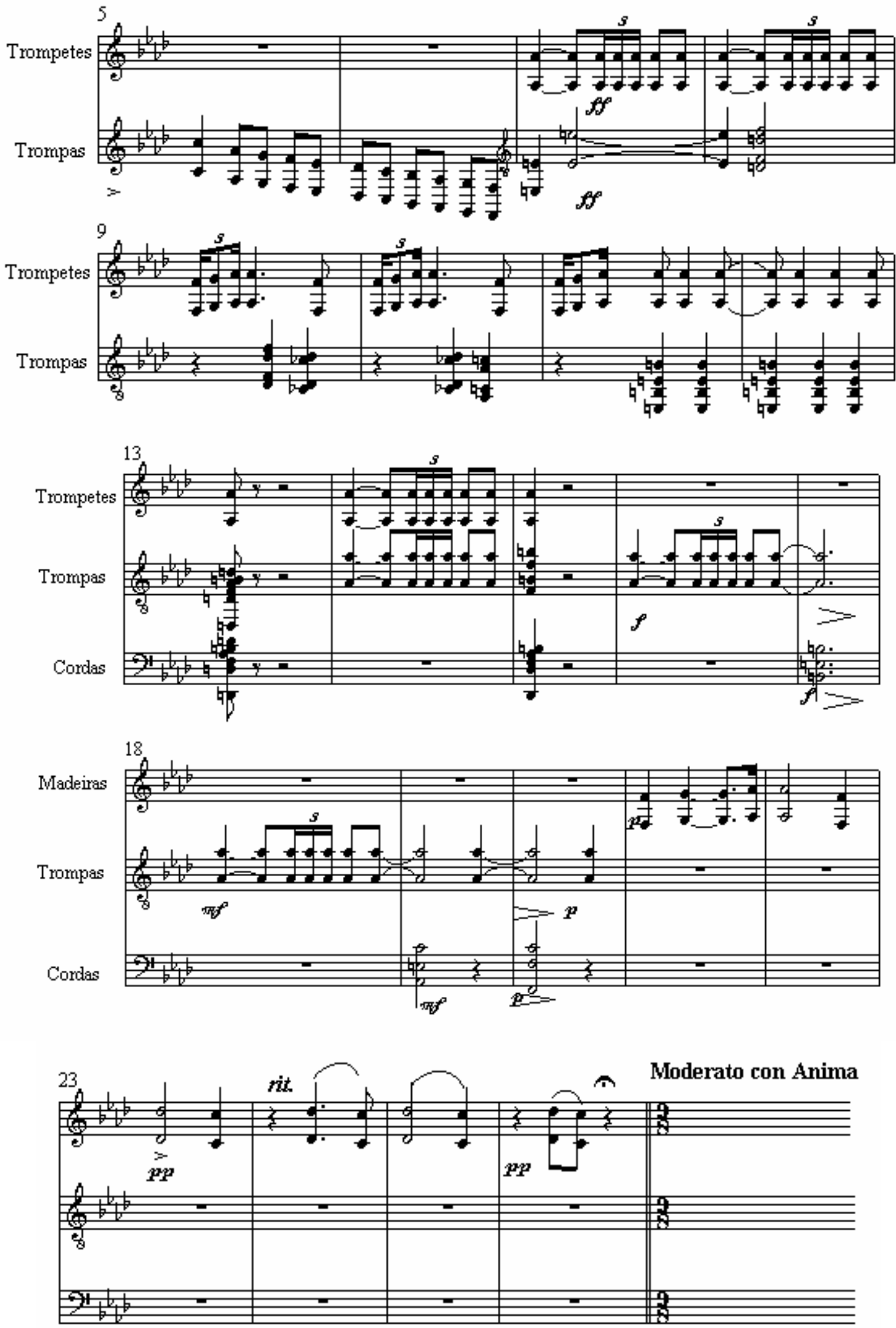
Iniciemos considerando os elementos verbais do texto musical. Os primeiros termos relevantes para esta análise encontram-se logo no c.1 (compasso 1) da partitura.

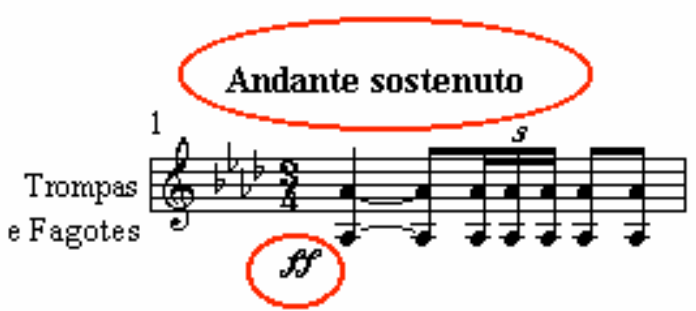

A intensão se caracteriza tanto pela utilização da dinâmica fortissimo, indicando uma aspectualização por intensidade do discurso que se segue, quanto pela indicação do andamento, onde o termo Andante tem sua espacialidade sustada e temporalizada pelo aspecto sostenuto, indiciando potencialização e predispondo assim o espaço narrativo mais para transformações do ser (estados de alma) que do fazer (estados de coisas).

Consideremos mais detalhadamente essa última indicação. Acompanha o verbete sostenuto na Collins encyclopedia of music a seguinte explicação:

sostenuto - 'sustained'. A direction to sustain the tone, which is usually equivalent to slowing the tempo ${ }^{179}$.

Há, portanto, uma aspectualização temporal que durativiza as formas discursivas. Prossigamos em nossa pesquisa, consultando o Petit Robert:

sostenuto - de façon égale et soutenue.

soutenue - 1. Qui se mantient à un certain niveau de pureté, d'élégance, évite toute familiarité - élevé, noble. 2. Qui se soutient, est constant, régulière.

3. Accentué, prononcé, intense ${ }^{180}$.

Entenda-se pois que o aparente caráter extenso do sostenuto, por estar relacionado a um prolongamento das durações, deve ser antes lido como uma intensificação da aspectualização durativa das formas discursivas, havendo pois uma concordância aspectual entre as duas formas de intensificação do discurso. Reforça-se ainda a durativização sugerida pelo Andante sostenuto quando contraposta à indicação de andamento do restante do 1.0 movimento, à partir do c.27, Moderato con anima, apontando mais uma vez ser significativa a aspectualização do Andante.

\footnotetext{
${ }^{179}$ Westrup \& Harrison, 1985: 515

${ }^{180}$ Robert, 1994: 2117, 2129
} 

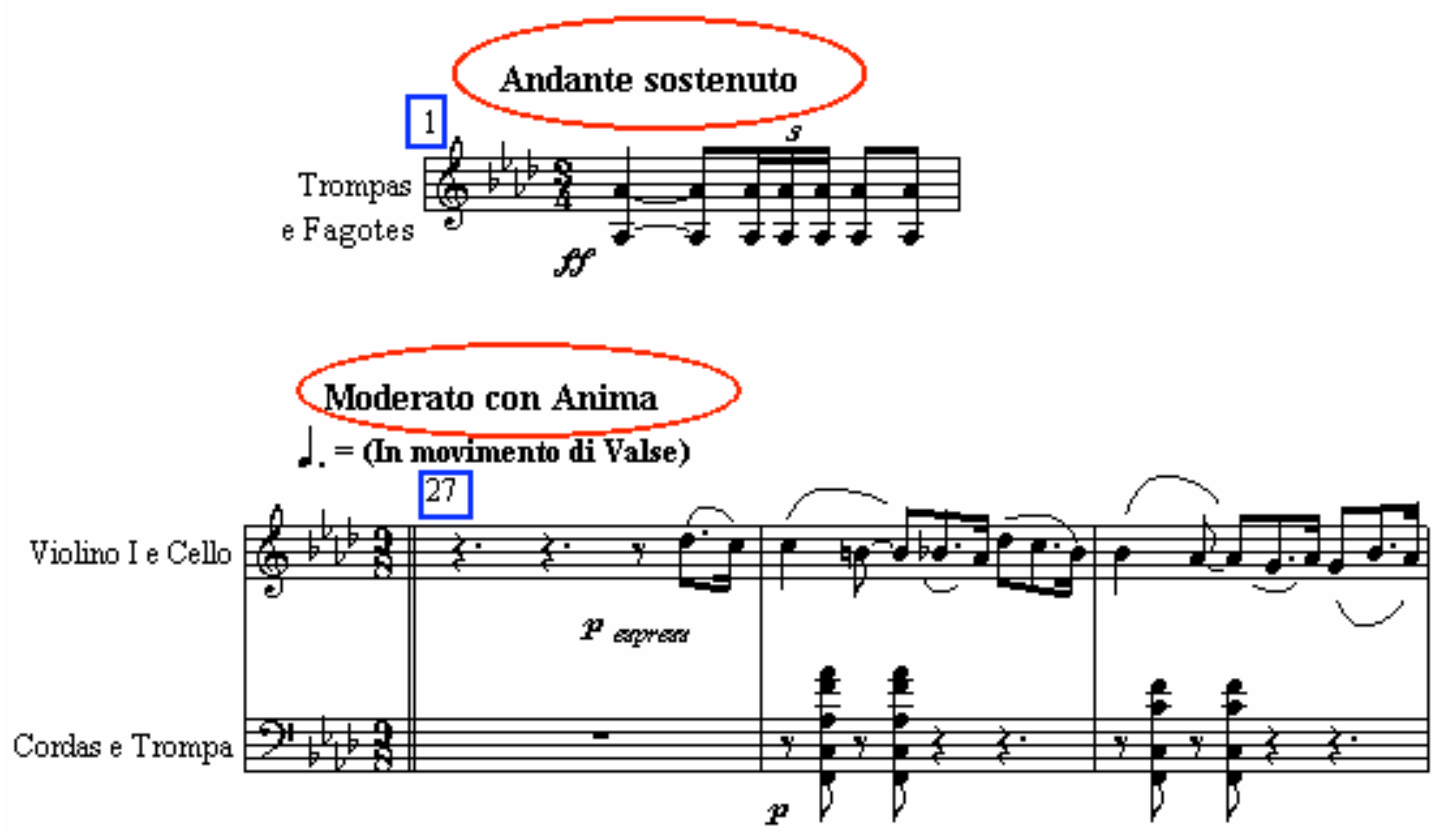

Relevemos agora a definição do Petit Robert em sua acepção de negação da familiaridade. A familiaridade conota intimidade, proximidade de relacionamento, e sua negação, distanciamento. Tal distanciamento, confirmado ainda pelos termos elevado e nobre, aponta para um desequilíbrio na relação intersubjetiva que propusemos anteriormente estar representada pela estrutura actorial 1. Assim, a aspectualização do destino aos olhos do espectador assume os contornos de um sujeito exagerado, sob a forma de uma aspectualização actancial da intensificação do discurso. Temos, assim, um único fator tensivo aspectualizado em suas três dimensões discursivas: temporal, espacial e actancial. A duração se associa nesse caso a uma espacialidade onde se promove o efeito de distanciamento e hierarquização da relação intersubjetiva.

Passemos agora ao texto musical propriamente dito já à luz de sua direcionalidade modulatória e aspectual.

Observemos inicialmente os dois primeiros compassos, executados pelas trompas.

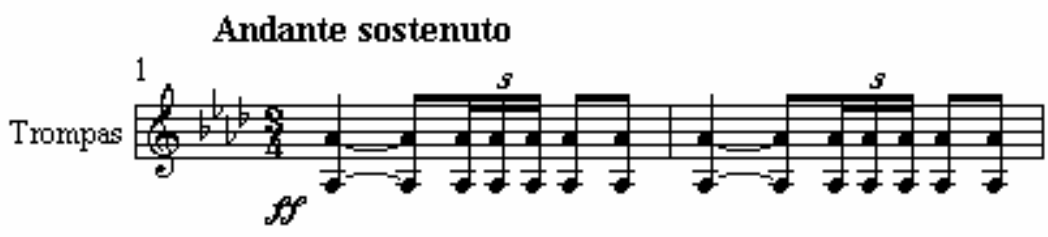

Não há variação de altura do som. Resulta daí tanto a reiteração do aspecto durativo, que aqui já começa a assumir os contornos de valor, quanto a delegação do sentido do trecho em questão às transformações rítmicas nele inseridas. Analisemo-las pois: 


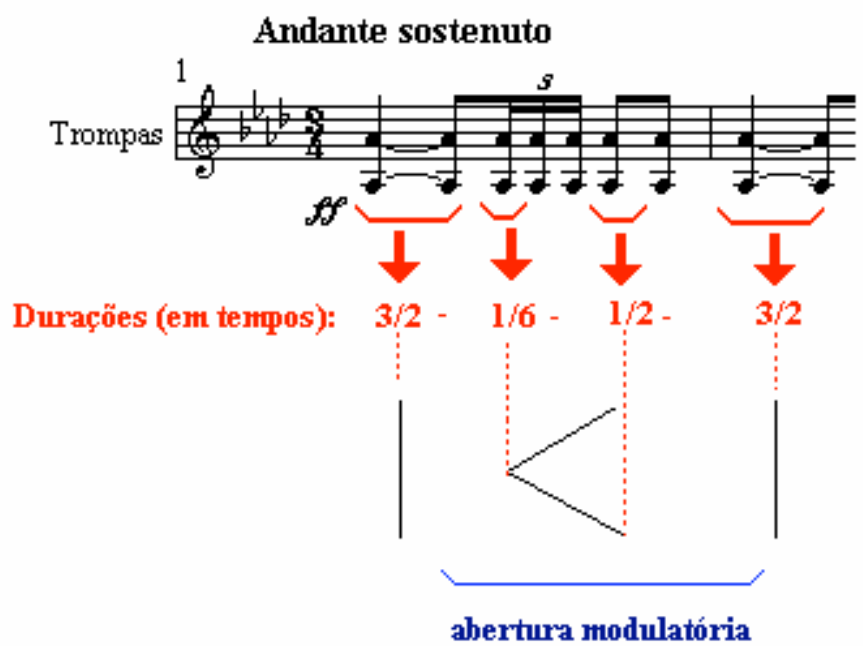

Estabelece-se uma abertura modulatória apontando do pontual ao durativo, o que confirma a assunção da duratividade à categoria de valor do discurso, por se instaurar uma virtualização do movimento modulatório em sua direção. Esse efeito de sentido advém da própria seqüência de durações das notas entre os primeiros tempos dos compassos 1 e 2:

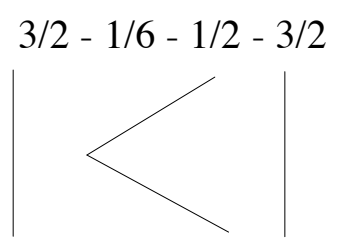

Estrutura-se assim a primeira unidade cíclica do texto, a partir da qual se estabelecem as categorias temporais propostas por Zilberberg ${ }^{181}$ : o tempo rítmico, ligado à foria pelos efeitos de sentido resultantes instantaneamente da confirmação ou não da expectativa de reiteração das unidades estruturais do texto; o tempo mnésico, estabelecendo os valores recursivos ao longo da extensão do discurso; o tempo cinemático, dando conta dos aspectos modulatórios e do estabelecimento de valores emissivos; e o tempo cronológico, pontuando e narrativizando o discurso com suas transformações de estado.

Detectamos portanto uma modulação de abertura em direção à duratividade do discurso. Continuando nosso exame, consideremos também os compassos 3 e 4:

${ }^{181}$ Zilberberg, 1990: 42-44 


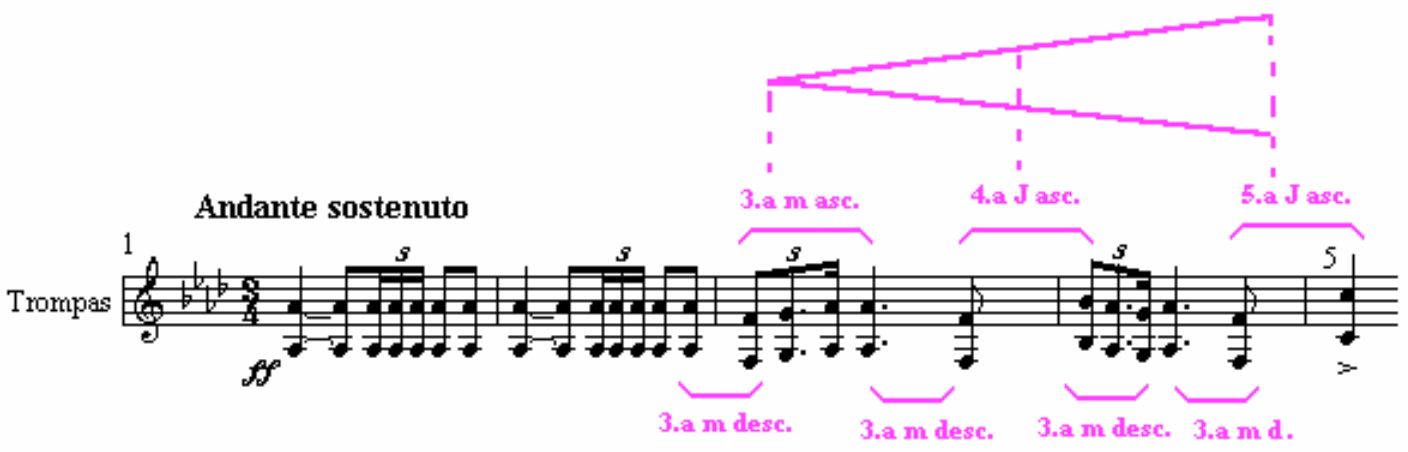

Vemos agora a modulação de abertura estender-se rumo à expansão espacial do discurso, sob a forma de uma abertura da tessitura em intervalos crescentes, assumindo-se a altura melódica enquanto instância espacial do discurso musical. Quanto à duratividade, nos compassos 3 e 4 , a proporção entre as durações passa para:
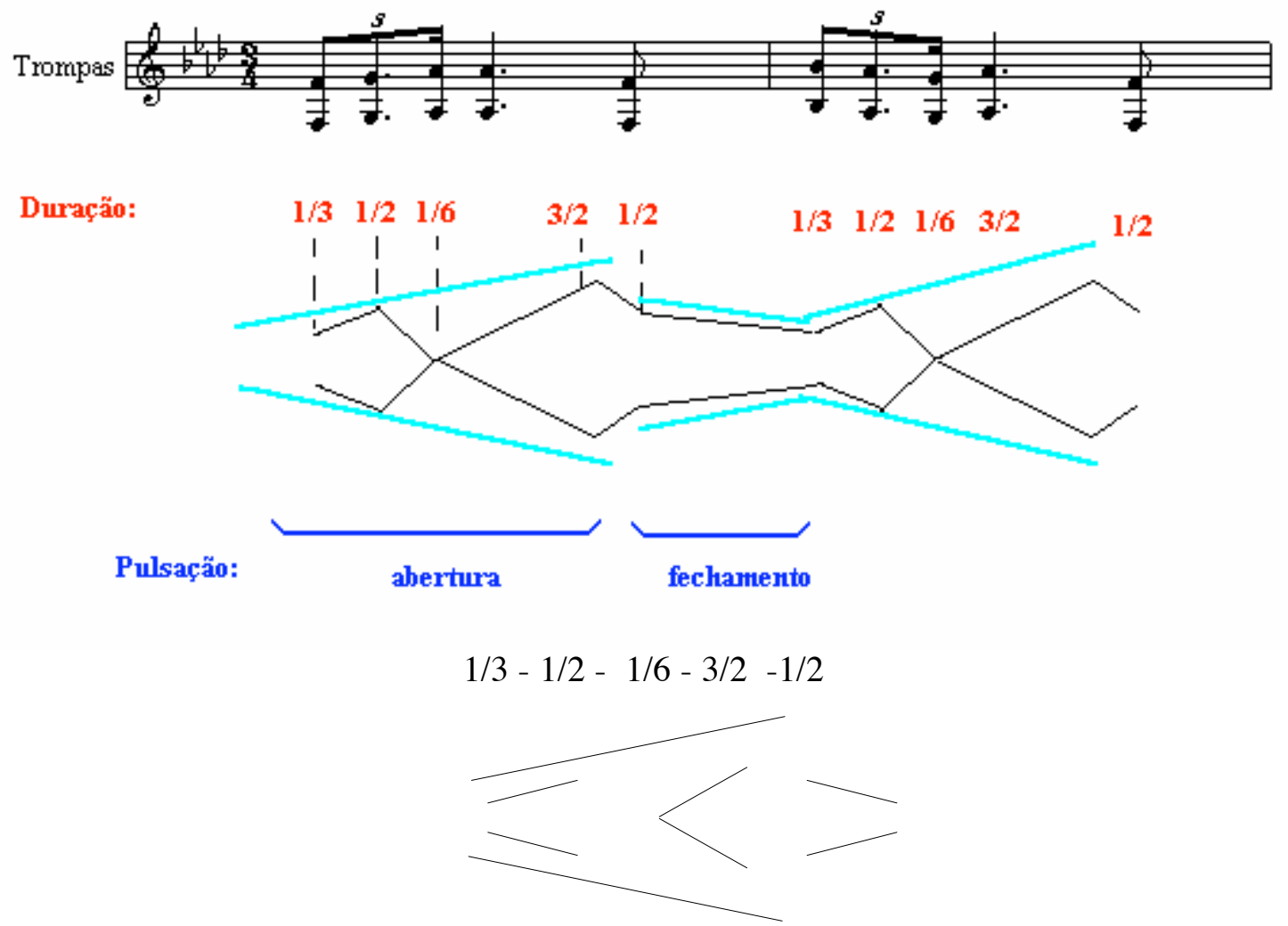

mantendo-se sob a forma de ondulação/pulsação modulatória.

Observemos agora a evolução da tessitura no trecho entre os compassos 1

e 7: 


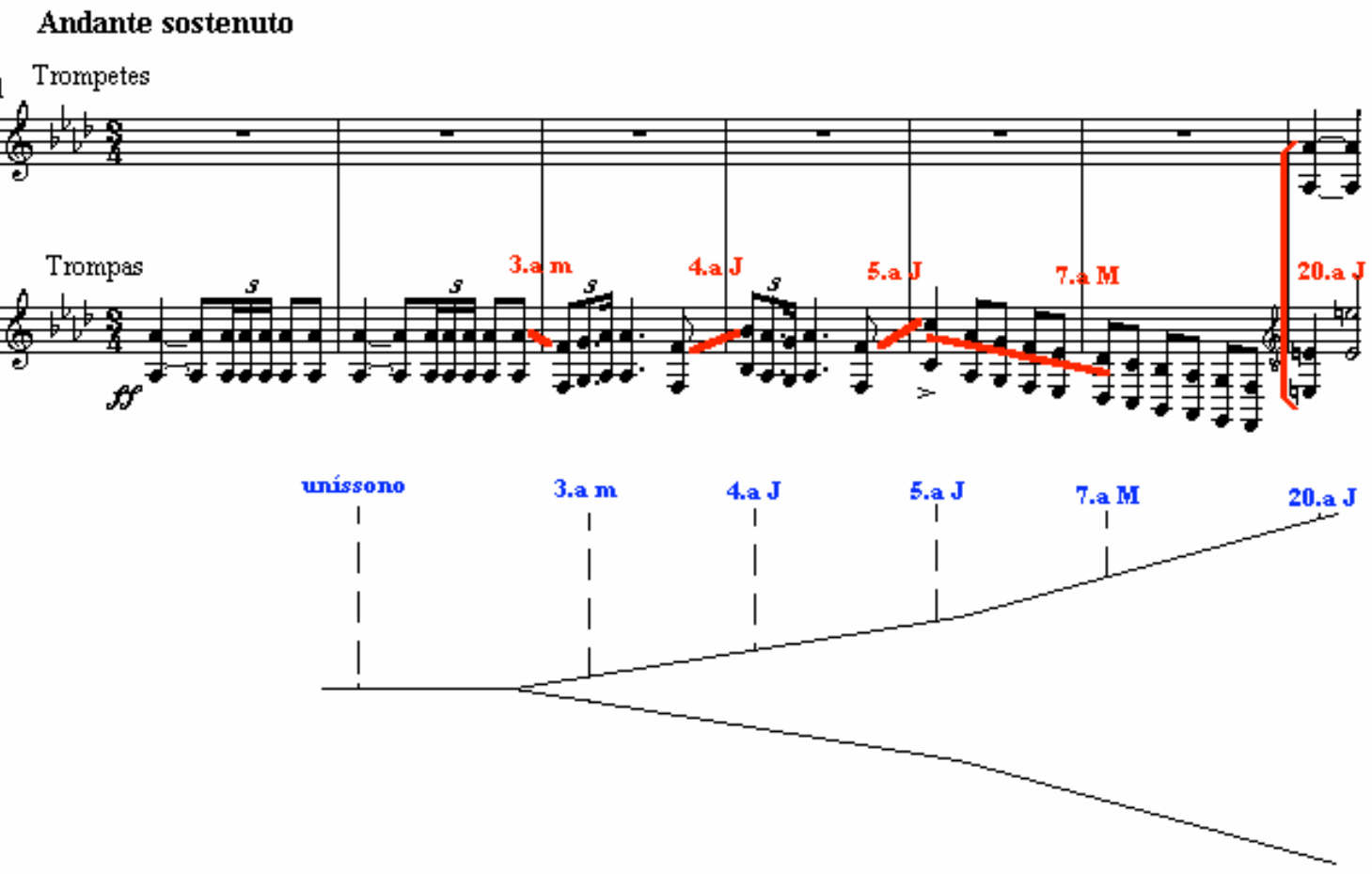

Verifica-se assim uma flagrante aceleração da abertura modulatória para uma aspectualização espacial com traço durativo, o que vem, em última análise, a reforçar o traço de exagero no nível actancial, compatível com a leitura feita da carta de Tchaikovsky.

Ainda em relação ao trecho que se estende dos compassos 3 a 7 , vale ressaltar alguns pontos importantes. Há uma relevante transformação de estado na cabeça do compasso 5, marcada pelo autor com um acento. A partir desse ponto, a abertura, que antes se verificava numa pulsação rítmica de amplitude crescente, passa a continuar sua progressão modulatória cursivamente.

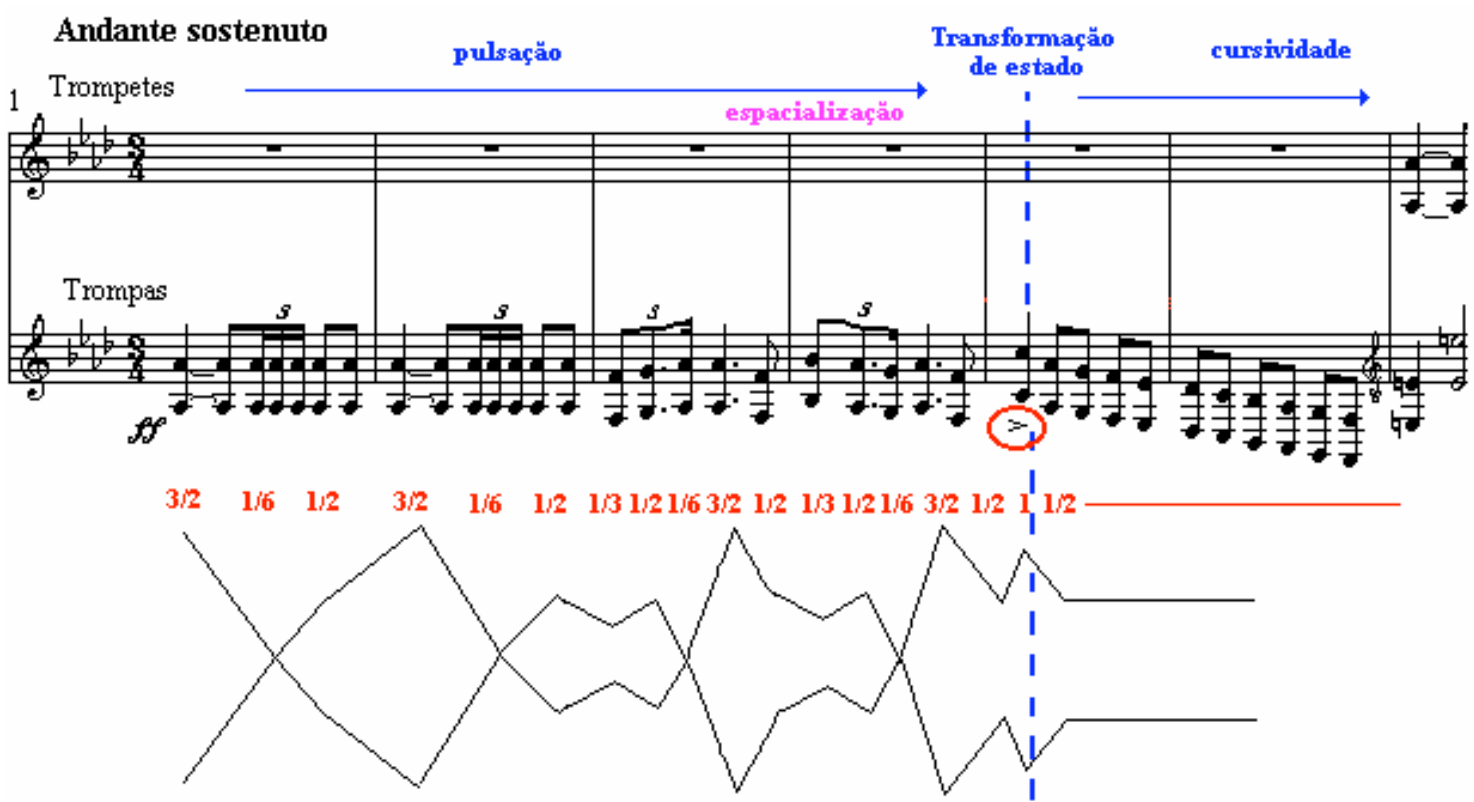

Assim, a aceleração da abertura modulatória marcada pela espacialização citada no parágrafo anterior resulta numa transformação de estado em função de uma 
mudança de isotopia, o que corresponde exatamente à transição aspectual do intenso para o excessivo descrita na Semiótica das paixões ${ }^{182}$.

Por um lado, o da intensidade, temos de tratar com um devir em curso de evolução, com dispositivos proto-actanciais que procuram estabilizar-se e onde a sensibilização, literalmente, se incorpora. Por outro lado, o do excesso, trata-se de um devir já evoluído, mas que ameaça regredir a dispositivos proto-actanciais desestabilizados... observa-se amiúde que o excesso assinala, no nível discursivo, uma mudança de isotopia, o que não é, em geral, o caso da intensidade. ${ }^{183}$.

Partiremos agora para uma discussão a respeito da configuração modal virtualizada no discurso musical. Não sendo possível identificar modalidades na música da mesma maneira com que se as reconhece no discurso verbal, sua presença, já que não manifesta, será postulada enquanto conversão ao nível narrativo das aspectualizações das modulações tensivas. Assim, a partir da convocação ao plano discursivo das modulações de nível profundo é que se torna possível recuperar a instância modal enquanto discretização das estruturas profundas no nível sêmio-narrativo. Tal procedimento se baseia na própria fundamentação conceitual do modelo de percurso gerativo do sentido compreendida através da perspectiva mais ampla que nos é apresentada na Semiótica das paixões:

$\mathrm{Na}$ ausência de manifestação direta ou indireta das modalizações, a observação das escolhas aspectuais dominantes permite postular a existência desta ou daquela modulação dominante no nível profundo, que teria sido convocada prioritariamente para a discursivização; suposta essa modulação como predominante, pode-se então suspeitar e prever que a organização modal, se houver uma em imanência, deveria estar afetada ou orientada. ${ }^{184}$

Assim sendo, podemos converter a modulação de abertura em modalização virtualizante $\mathrm{e}$, analogamente, a modulação cursiva em modalização atualizante. Disso resulta em última análise a virtualização de um querer que se atualiza em poder. Note-se que a aspectualização associada a esse poder mais uma vez é compatível com a leitura que fizemos anteriormente referente ao texto verbal, pela qual chegamos a um tipo de relação intersubjetiva compatível por exemplo com a concepção de um destino exageradamente onipotente aos olhos dos homens.

Os compassos 7 a 9 repetem melodicamente os três primeiros compassos do texto, reinstaurando o tempo rítmico no discurso, com a introdução dos trompetes:

\footnotetext{
${ }^{182}$ Greimas \& Fontanille, 1993: 169

${ }^{183}$ Idem, pg. 170

${ }^{184}$ Ib., pg.36-37
} 


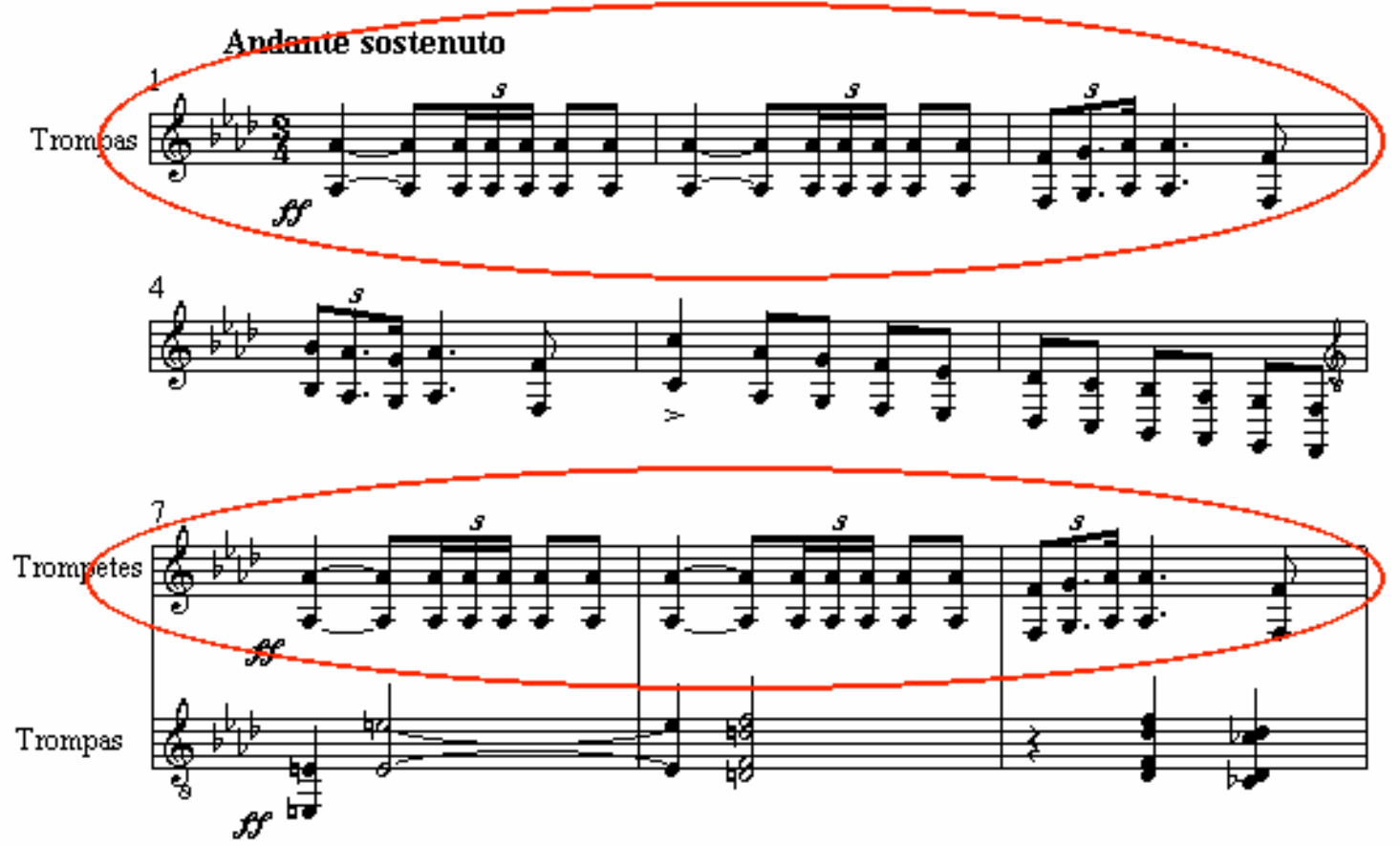

O sentido, portanto, fica basicamente delegado ao aparecimento da polifonia e à configuração harmônica consequiente desse advento. O primeiro efeito de sentido detectável é a continuação da abertura modulatória devido ao aumento de sonoridade resultante da instauração da polifonia. O tempo mnésico termina por estabelecer tal gradação à medida que remete à situação inicial e indicia o crescimento dinâmico da unidade estrutural referida.

Consideremos agora o trecho entre os compassos 7 e 11:

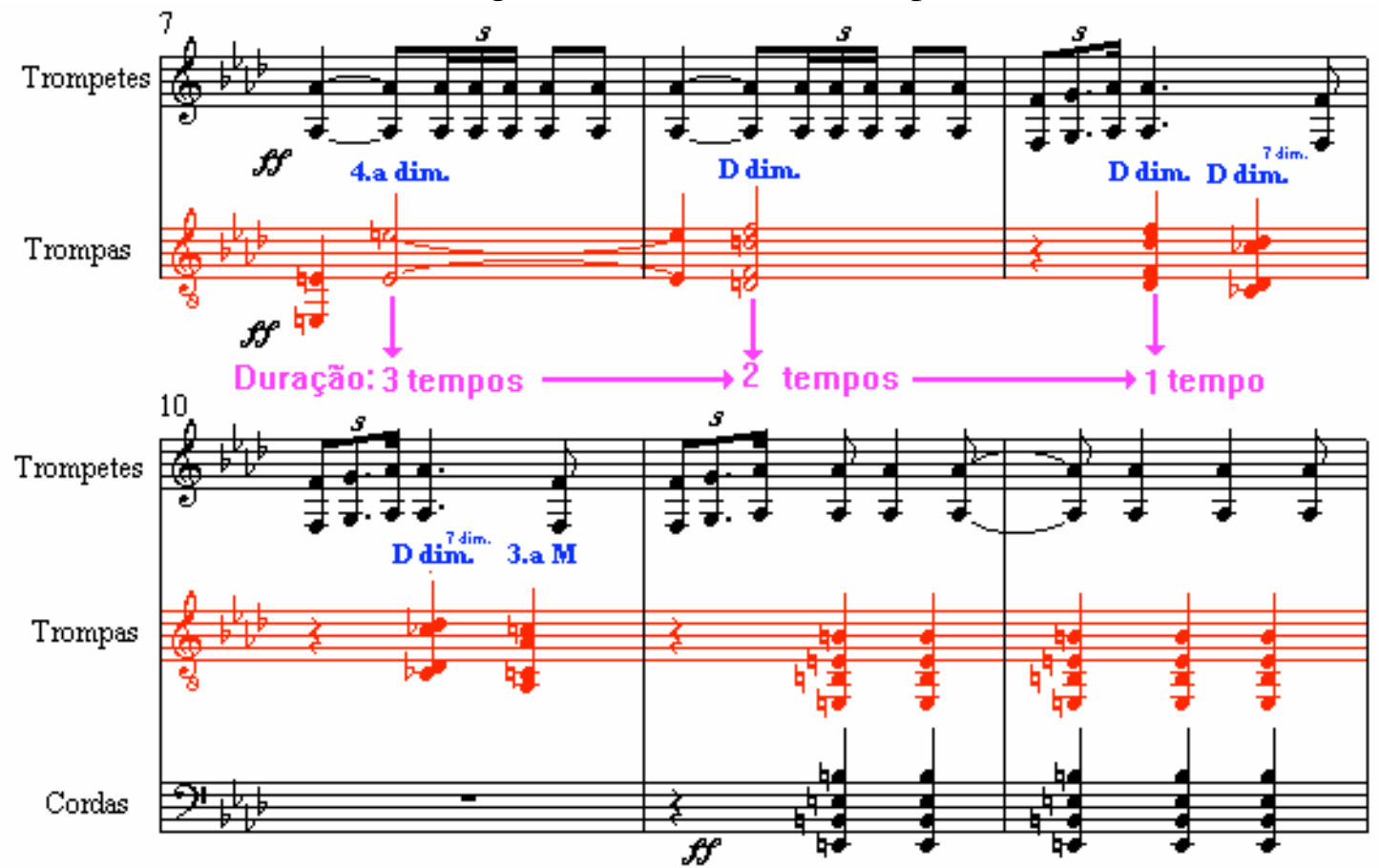

A figura de acompanhamento executada pelas trompas dos compassos 7 a 11 apresenta dois fatores pertinentes para essa análise. O primeiro diz respeito à pontualidade. Introduz-se no fluxo modulatório um elemento pontual que vai se acelerando ao longo dos próximos compassos, acompanhando a espacialização do 
discurso (formalmente falando, trata-se de um acorde no segundo tempo de cada compasso, que evolui desmembrando-se polifônica e ritmicamente). O segundo se refere à modulação tensiva propriamente dita discursivizada harmonicamente. É igualmente claro seu percurso da tensão à distensão harmônica, sem chegar ao relaxamento: partindo de um intervalo de 4.a diminuta no compasso 7 (tensão), atingem-se os acordes de diminuta dos compassos 8 a 10 , verificando-se nesse trecho paralelamente à espacialização do discurso uma gradual diluição tensiva na instância harmônica. Tal processo porém se interrompe entre os compassos 11 e 13, como veremos mais tarde.

A célula melódica do c.9 frustra a expectativa de um desdobramento análogo àquele que sofreu no c.4, repetindo-se nos compassos 10 e 11:
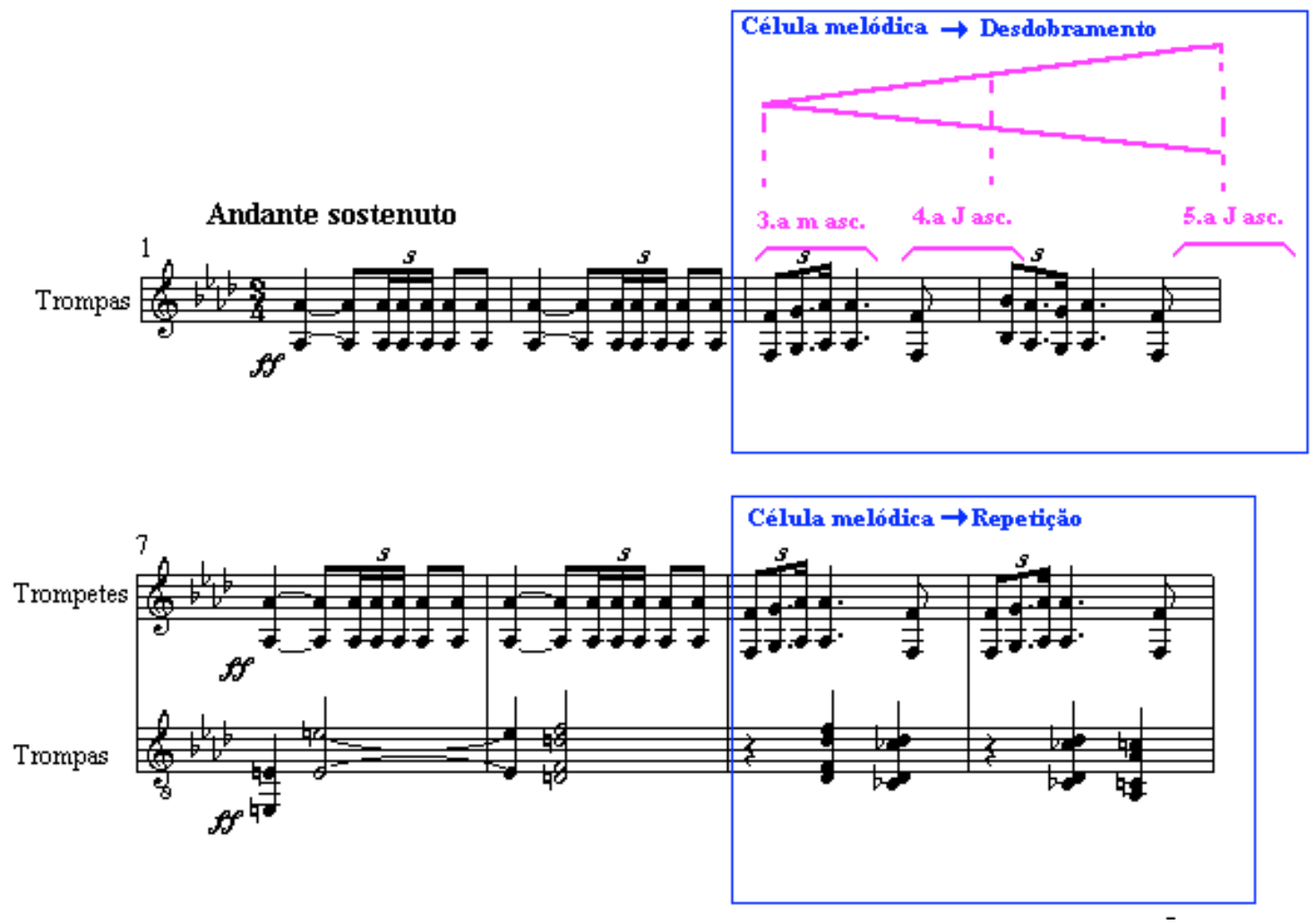

A remissividade, essencialmente associada à intensificação, progride ainda até o compasso 11, levando a concentração do discurso a exacerbar-se então na repetição de uma única nota: 


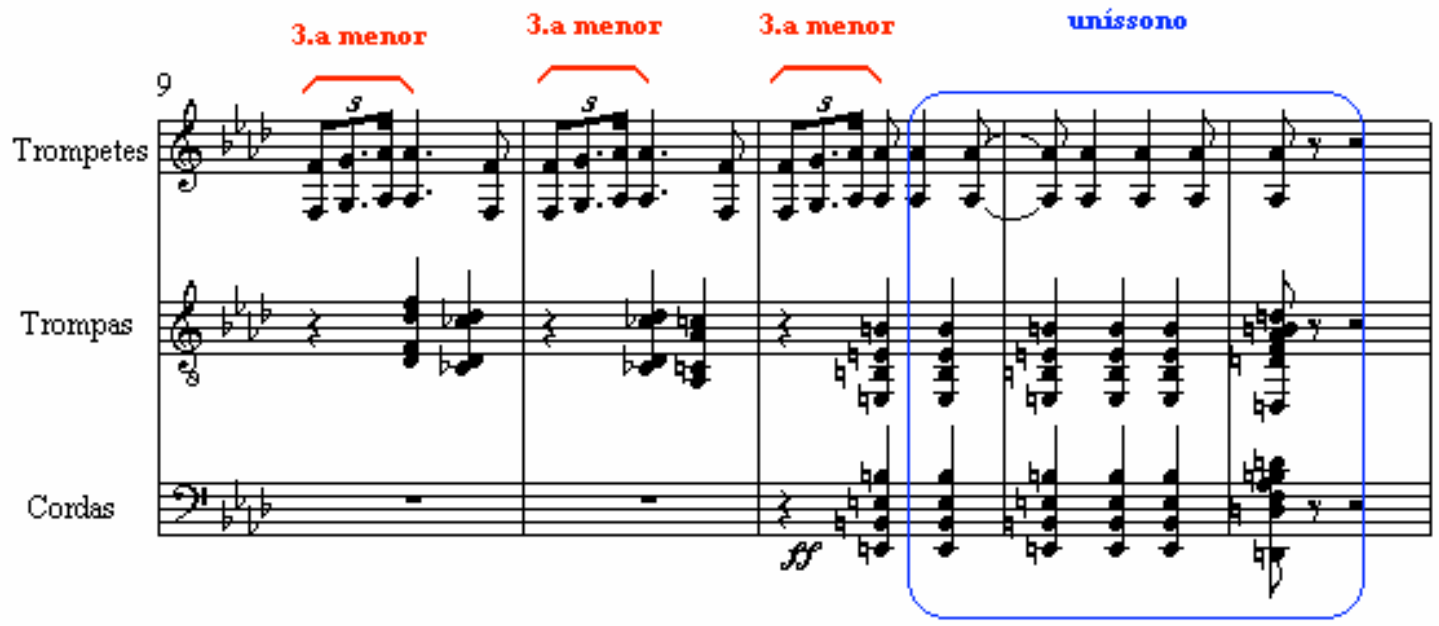

Analogamente, findo o ciclo harmônico das trompas, a expectativa é de um novo desdobramento que não se confirma, e passa a repetir compulsivamente um único acorde em discordância rítmica (causando quebra de expectativa) com o elemento melódico:

1 o ciclo harmônico

ciclo suspenso

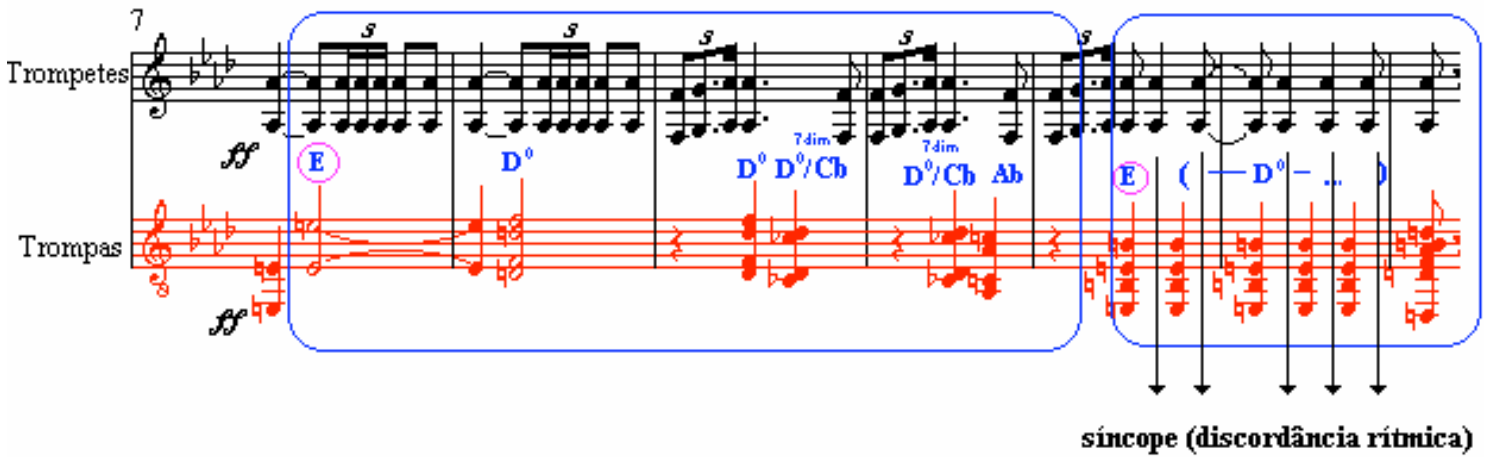

Para visualizar o clímax da progressão acima, tomemos o trecho seguinte:

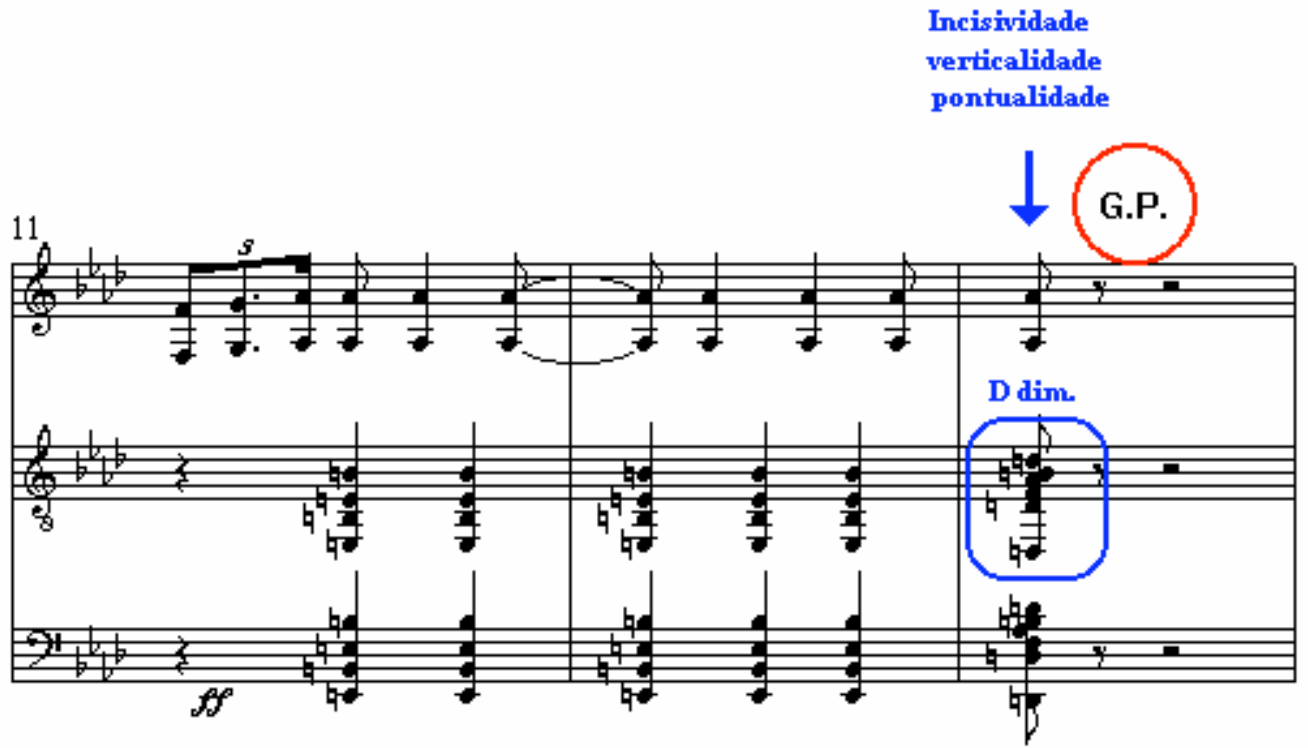


No compasso 13, encontramos a parada, assinalada pela GP (grande pausa - todos os instrumentos da orquestra param de tocar). O estancamento do devir, a suspensão da narrativa; o clímax se dá à medida que o excesso de concentração atinge a pontualidade, causando a aparente suspensão do devir. Vale lembrar ainda que é justamente a parada o ponto do percurso narrativo que, no discurso verbal, costuma se discursivizar através do desdobramento polêmico entre sujeito e anti-sujeito. Chegamos assim a mais uma estrutura de nível profundo compatível com a leitura do texto verbal apresentada em nossa análise. Exponhamos agora com maior detalhamento como se dá essa relação.

O compasso 13 introduz um elemento pontual, incidindo verticalmente sobre o fluir modulatório do tempo cinemático, discursivizado pela entrada das cordas. $\mathrm{O}$ acorde de diminuta é curto e incisivo, destacando-se sua pontualidade pela duração por si mesma pontual e pela tensão harmônica que o acompanha. A transformação de estado que se segue consiste na própria interrupção do discurso, retomado logo em seguida. Discretizada a modulação, vem à tona uma modalização deôntica, a própria materialização musical da espada de Dâmocles, a invencibilidade do destino e do dever. O silêncio nos remete também à interrupção do devir, do discurso, e, no nível profundo, reportando-nos à análise do texto verbal, da própria vida.

Atingido o clímax de tensão no episódio deôntico, inicia-se o processo de distensão. Os compassos 14 e 15 apresentam uma nova retomada e interrupção do motivo inicial , começando assim a diluição da tensividade através do esvaziamento tensivo trazido pela previsibilidade:

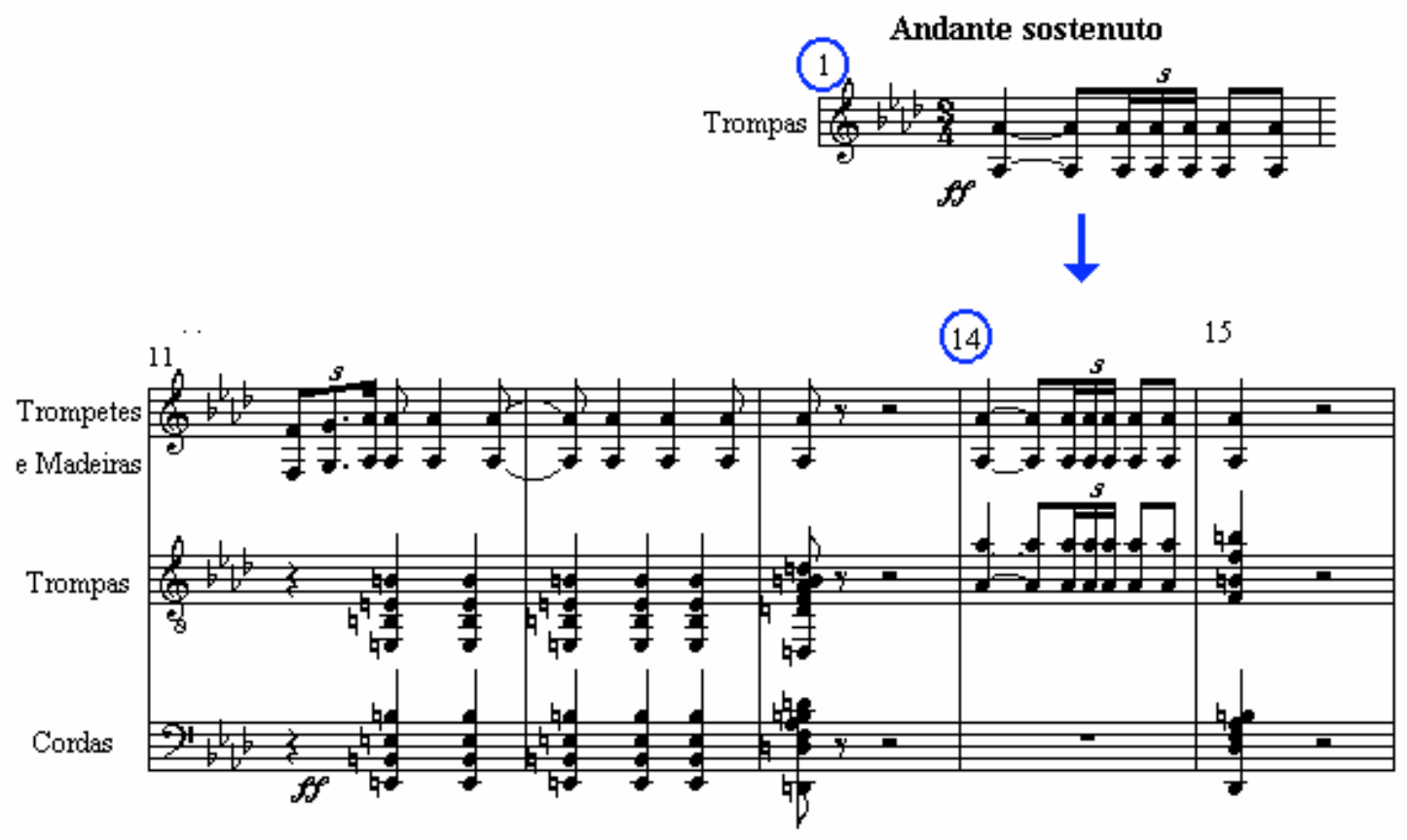

Tal diluição é imediatamente visível a partir do compasso 16 pela gradual diminuição tanto da dinâmica, desde o fortissimo inicial até o pianissimo dos compassos 23 e 26, quanto do andamento, que começa a retardar no c.24 até estancar na fermata do c.26: 
Diluição dinâmica [intensidade decrescente]

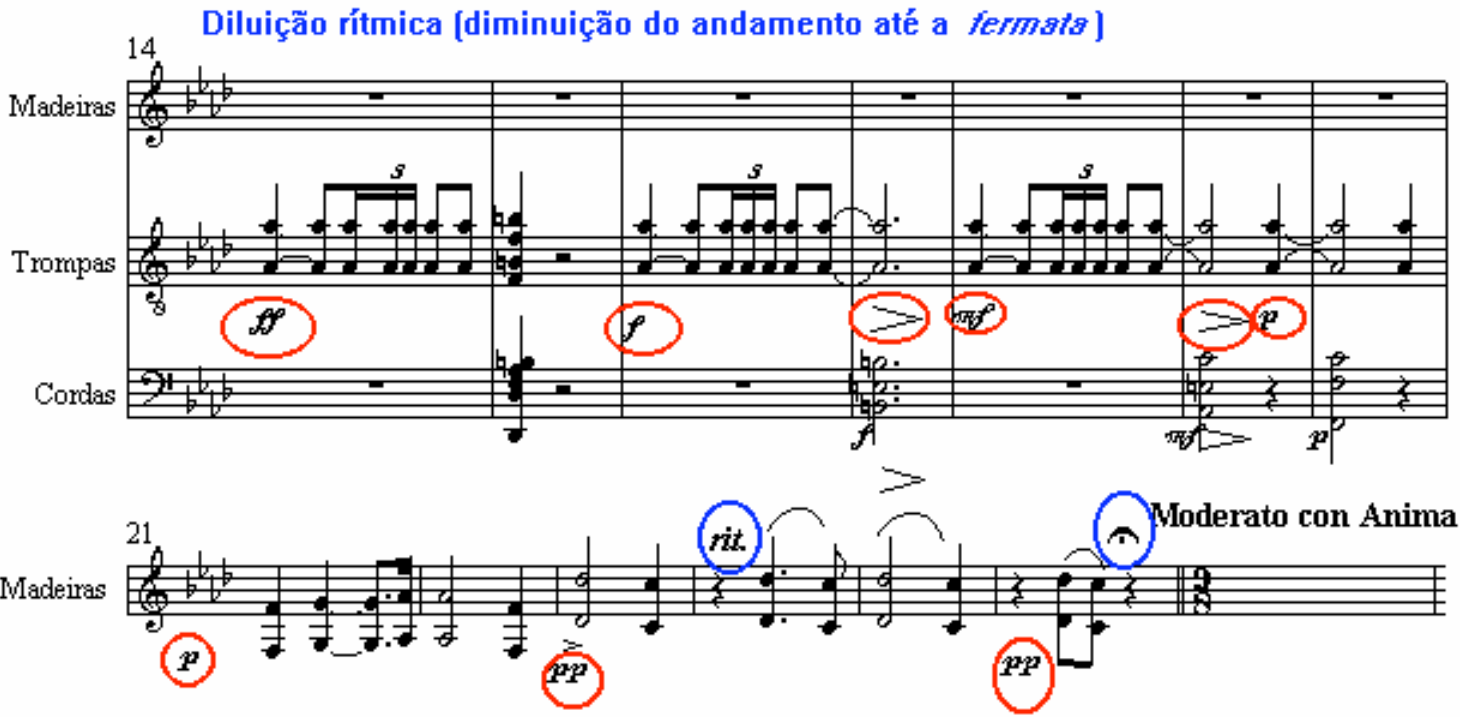

Também a harmonia transita da tensão no c.17 ao relaxamento no c.20, passando pela distensão no c.19., em acordes localizados na cabeça dos compassos, e não mais em síncopes, também indiciando distensão. O esparsamento do motivo melódico culmina com uma transformação de estado, discursivizada pela volta à monofonia no c.21, com a introdução das madeiras:

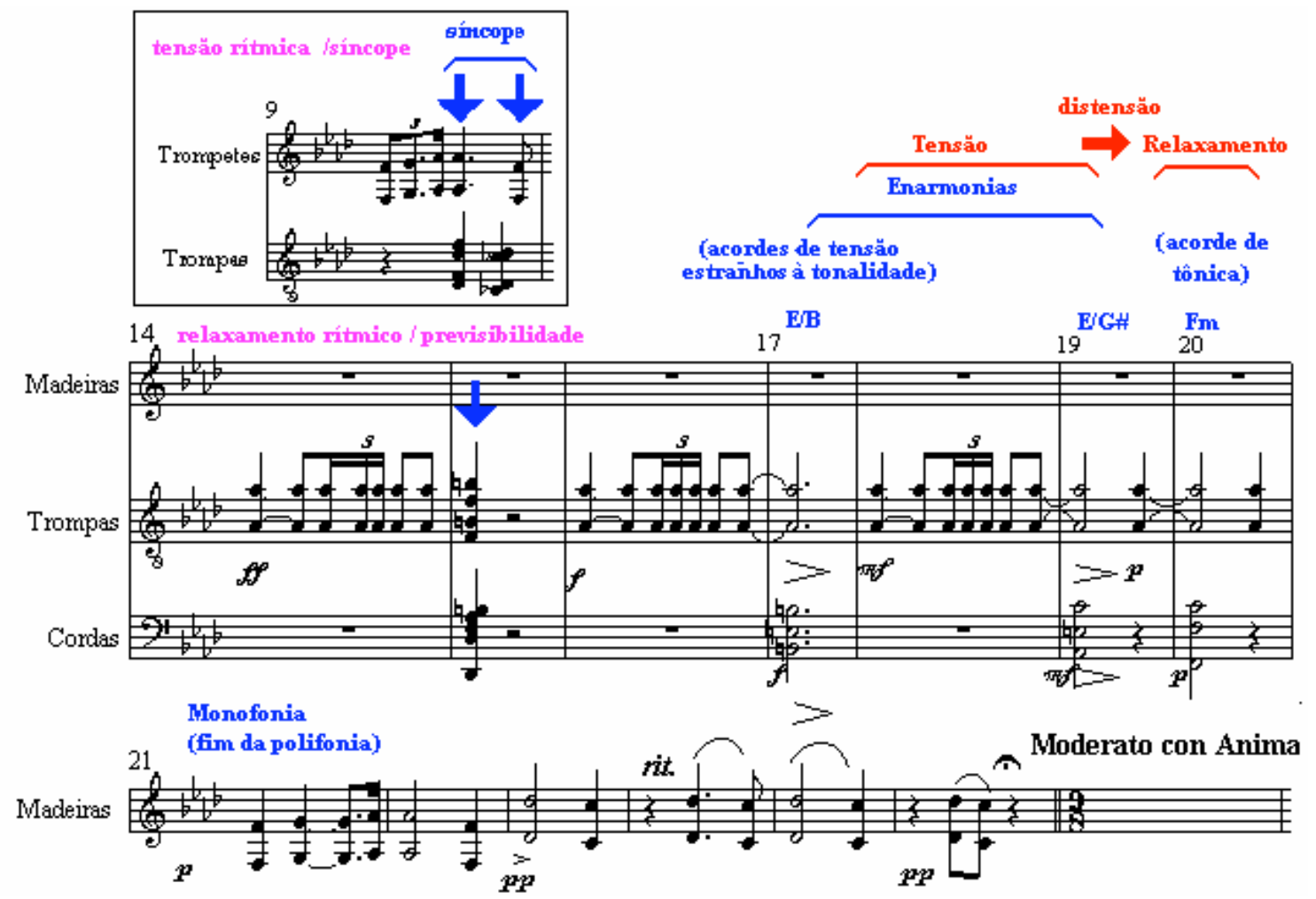

A solução da tensão harmônica, sintomaticamente nomeada cadência pela teoria musical, introduz no compasso 20 um fechamento modulatório que se discretiza pela modalidade do saber, recuperando e restabelecendo a previsibilidade. Gera-se assim um efeito de sentido equivalente a uma sanção cognitiva, que poderíamos 
relacionar em nossa leitura do texto verbal àquela do sujeito que reconhece a precariedade de sua condição.

Por último, coroando o quadro de analogias entre os dois textos, verificamos que a direcionalidade a partir do c.21 caracteriza-se inicialmente pela abertura modulatória, discursivizada nas instâncias melódica e temporal, e, em seguida, pela reiterada hesitação na confirmação da terminatividade, na conclusão do discurso, hesitação essa que, por sua repetição, acaba gerando ainda um aspecto cursivo em sua apresentação:

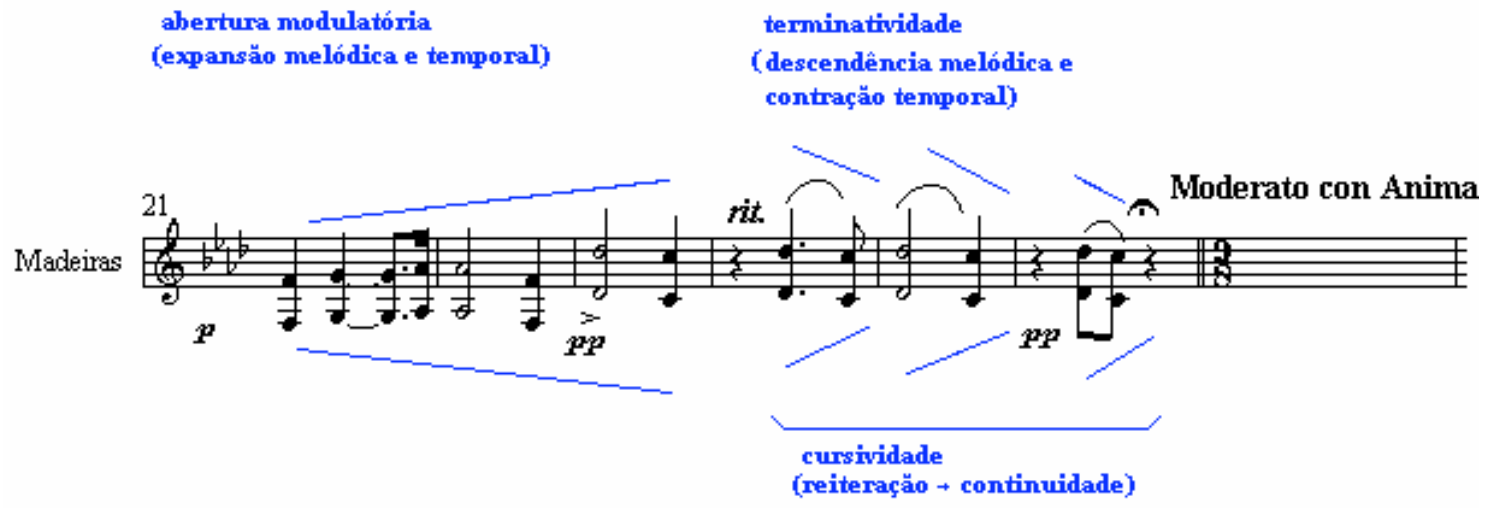

Depreendem-se daí: um elemento a ser analisado posteriormente (a cursividade, em particular); a abertura sugerindo um querer que não se realiza (hesitação e inconclusão); a própria terminatividade sugerindo uma sanção cognitiva, sanção essa compatível com o programa de resignação a que chegamos anteriormente no texto verbal.

Encerrada assim uma primeira etapa da identificação dos mecanismos discursivos musicais necessários à geração dos efeitos de sentido propostos no trecho citado da carta de Tchaikovsky e verificada parcialmente a correspondência entre os respectivos planos do conteúdo dos textos verbal e musical, mostra-se assim produtiva a extensão e o aprofundamento de nossa análise de modo a considerarmos outros segmentos da carta do compositor russo ao mesmo tempo que enfim sistematizamos e formalizamos o equacionamento modal que delineia os estados patêmicos em cada texto, buscando assim estabelecer os possíveis elos de ligação entre os mecanismos de geração de sentido peculiares a cada forma discursiva. Prossigamos pois retomando a carta a partir do trecho seguinte:

Il ne nous reste plus qu'à nous résigner, à nous livrer à une tristesse stérile:

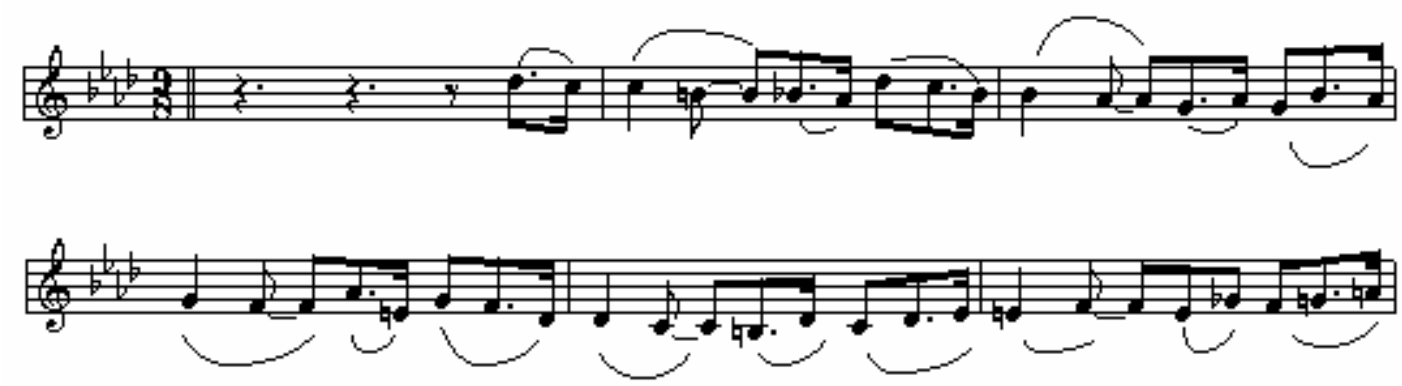


Le sentiment de la tristesse et du désespoir devient toujours plus fort et poignant ${ }^{185}$.

Eis agora a partitura do trecho da sinfonia a que se refere essa segunda parte da carta:

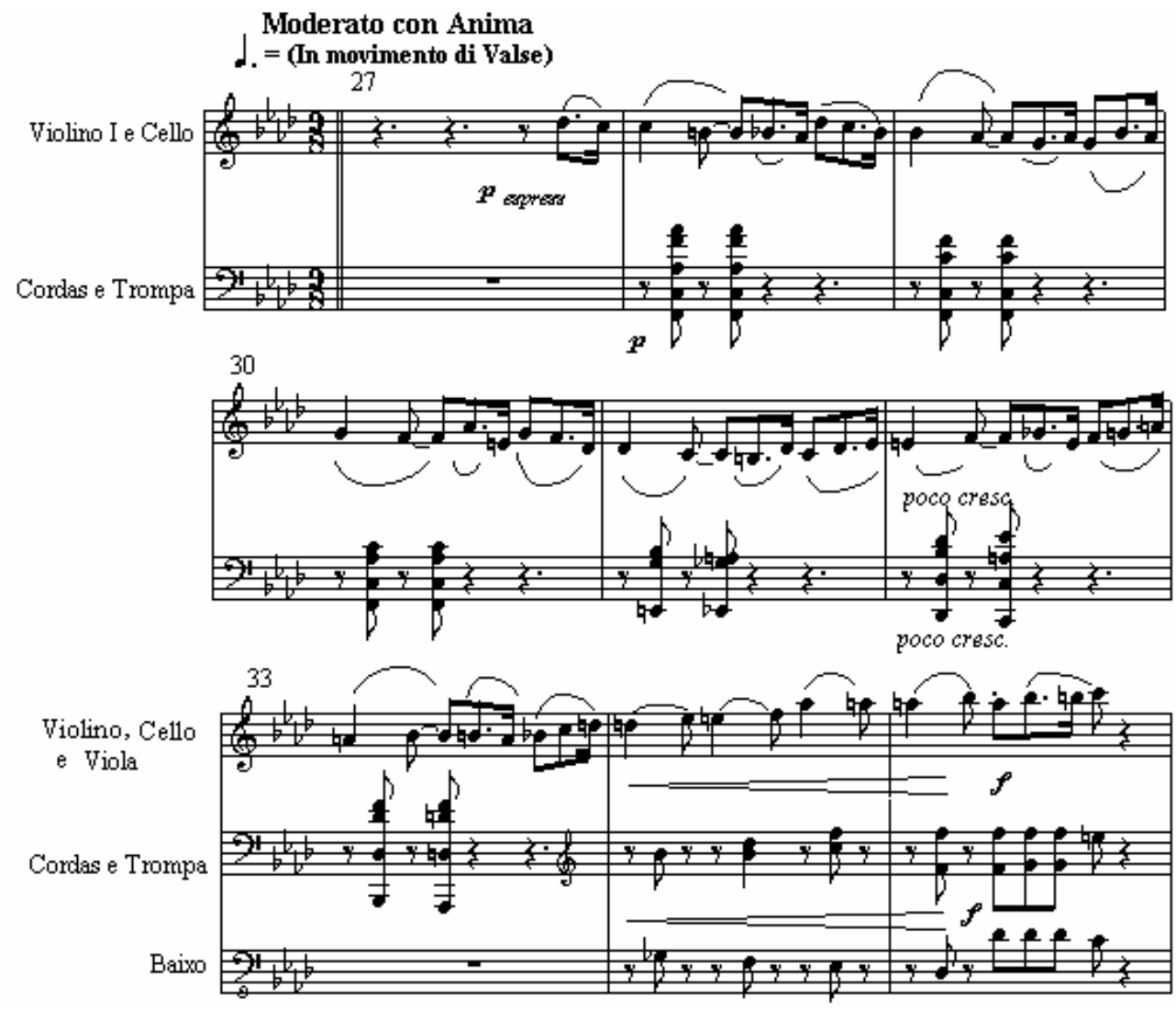

Consideremos inicialmente o texto verbal. Logo no primeiro parágrafo, evidencia-se a paixão da resignação, onde um programa narrativo de liqüidação da falta passa a ser assumido pela instância patêmica do discurso, caracterizando-se mais uma vez um modo de existência potencializado para o sujeito. A resignação, segundo o Petit Robert, corresponde ao estado de accepter sans résister quelquechose de pénible ${ }^{186}$. Isso estabelece um percurso narrativo onde o sujeito de um querer-não-ser (recusar-se, resistir a) passa a não-querer-não-ser (não resistir, aceitar, resignar-se). A ausência de alternativas sugere imediatamente um não-poder-não-ser, que também se estabelece enquanto percurso à medida que retomamos o trecho inicial, onde a polêmica entre $o$ homem e o destino pressupõe um crer-poder-não-ser, que aqui, através da sanção cognitiva, se reequaciona como crer-não-poder-não-ser. Identificamos assim na resignação a impotência do sujeito ante ao seu desdobramento polêmico contra o antisujeito, impotência essa que acarreta sua "derrota" no percurso narrativo por ele próprio sancionada cognitivamente. A sanção atualiza a modalidade epistêmica cursiva do crernão-poder, vindo à tona um saber-não-poder de natureza terminativa, que gera o efeito de desfecho final característico da resignação. Tal desfecho modulatório sugere ainda a possível incorrência de uma modalidade deôntica responsável pelo aspecto pontualizante, irrecorrível (Il ne nous reste plus qu'...) da sanção, efeito esse que se

${ }^{185}$ Tchaikovsky, 1985: 132

${ }^{186}$ Robert, 1994: 1951 
explica facilmente pela correlação semântica entre não-poder-não-ser e dever-ser, completando-se assim o quadro modal da resignação enquanto paixão complexa:

estado 1

(revolta)

crer-poder-não-ser

querer-não-ser

não-dever-ser desdobramento polêmico

(derrota)

(não-crer-poder-não-ser)

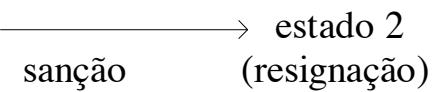

crer-não-poder-não-ser saber-não-poder-não-ser (não-poder-não-ser) não-querer-não-ser dever-ser

Feito um breve inventário modal da resignação, debrucemo-nos sobre a tristesse stérile aludida por Tchaikovsky.

Tristesse - État affectif pénible, calme et durable; envahissement de la conscience par une douleur, une insatisfaction, ou par une malaise dont on ne démêle pas la cause, et qui empêche de se réjouir du reste ${ }^{187}$.

Trata-se a tristeza de um estado de disforia causado pela disjunção com os valores positivos, eufóricos, do sistema estabelecido pelo discurso (insatisfaction) ou da conjunção com os valores negativos/disfóricos (douleur) do mesmo. O Robert sugere ainda duas aspectualizações: uma por duratividade (durable), outra por insuficiência (calme) ${ }^{*}$. Temos então um querer-ser em conflito com um crer-não-poder-ser, aspectualizado como durativo e distenso (é incoerente semanticamente que seja relaxado, devido à presença da dor. $\mathrm{O}$ aspecto dinâmico da distensão aponta com mais clareza para um mesmo traço profundo de extensão, aspectualizado discursivamente em sua dispersão temporal e tensiva). Antes de prosseguirmos pelas modalidades deônticas e atualizantes, consideremos o termo stérile, com que o autor qualifica e aspectualiza sua tristeza: positif. $^{188}$

Stérile - Qui ne produit rien, ne donne naissance à aucune création, à aucun résultat

O traço de impossibilidade de realização presente no termo conduz imediatamente a um não-poder-ser, instaurando a dimensão atualizante no diagrama modal da paixão referida. Também a "invasão da consciência por uma dor... cuja causa se desconhece" sugere cognitivamente um não-saber-ser e, se necessária uma complementação em nível deôntico, um dever-não-ser. Assim, abandonados a uma tristeza estéril configura-se modalmente enquanto paixão simples correspondente à etapa final da paixão complexa de resignação conforme apresentada no texto citado, podendo ser representada modalmente como:

querer-ser

${ }^{187}$ Ib. p. 2317

* Parece bastante defensável conceber o termo calme enquanto aspectualização actancial com o traço de insuficiência. Concordariam assim as convocações temporal e actancial, sugerindo a discursivização de um único traço semântico do nível profundo: a diluição tensiva, tomada como estensão na colocação subseqüente.

${ }^{188}$ Ib. p. 2145 
(crer-não-poder-ser )

não-poder-ser

não-saber-ser

dever-não-ser

A primeira sentença do 2.o parágrafo basicamente aspectualiza o quadro patêmico do 1.o, intensificando-o, tornando-o plus fort et poignant. A segunda já se refere a outro episódio musical que analisaremos posteriormente. Agora, antes de passarmos a considerar o texto musical, verifiquemos se désespoir pode ser visto como aspectualização de tristesse, ou se representa uma alteração no quadro modal a que chegamos até o presente.

Désespoir - 1. Perte d'un espoir ou de tout espoir; état d'une personne qui n'a plus d'espoir. 2. Affliction extrême et sans remède; état d'une personne qui n'a pas d'espoir.

Affliction - Peine profonde, abattement à la suite d'un coup du sort, d'un grave revers.

As duas definições acima salientam a complexidade do quadro passional através da pressuposição de um estado anterior contrastante. O desespero se apresenta como a perda da esperança, caracterizando o percurso crer-poder-ser $\rightarrow$ não-crer-poderser ${ }^{\rightarrow}$ crer-não-poder-ser, e seu componente de aflição aspectualiza o equacionamento modal acima quanto à intensidade/tensividade (extrema, profunda), polarizando disforicamente o estado conseqüente (um grave revés), e quanto à duratividade, projetando-se cursivamente sobre o devir ao se definir como état d'une personne qui n'a pas d'espoir. Fica assim claro tratar-se simplesmente de uma aspectualização da configuração modal anterior. Consideremos agora portanto $o$ texto musical correspondente ao trecho da carta analisado, especialmente no que tange às modulações e aspectualizações detectáveis em seu plano discursivo.

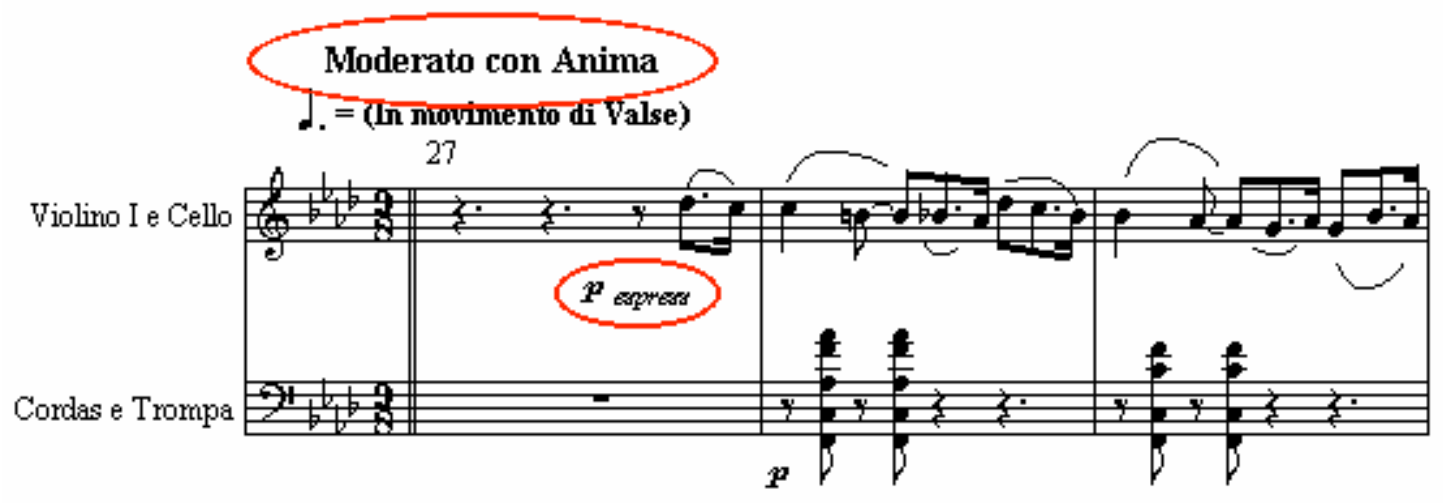

Tanto as indicações de andamento (Moderato con Anima) quanto de dinâmica (piano espressivo) apontam para a discursivização em suas respectivas categorias (temporal e actancial ${ }^{*}$ ) de um mesmo percurso tensivo. Caso nos baseássemos apenas no léxico, teríamos:

\footnotetext{
* De fato, o equivalente no discurso musical da aspectualização actancial parece ser a dinâmica. O estranhamento inicial causado por essa analogia se dilui quando exemplificamos através de actantes insuficientes e exagerados e, por trás da utilização explícita ou implícita, chegamos invariavelmente aos advérbios de intensidade, estabelecendo o elo conceitual com a intensidade do elemento sonoro.
} 


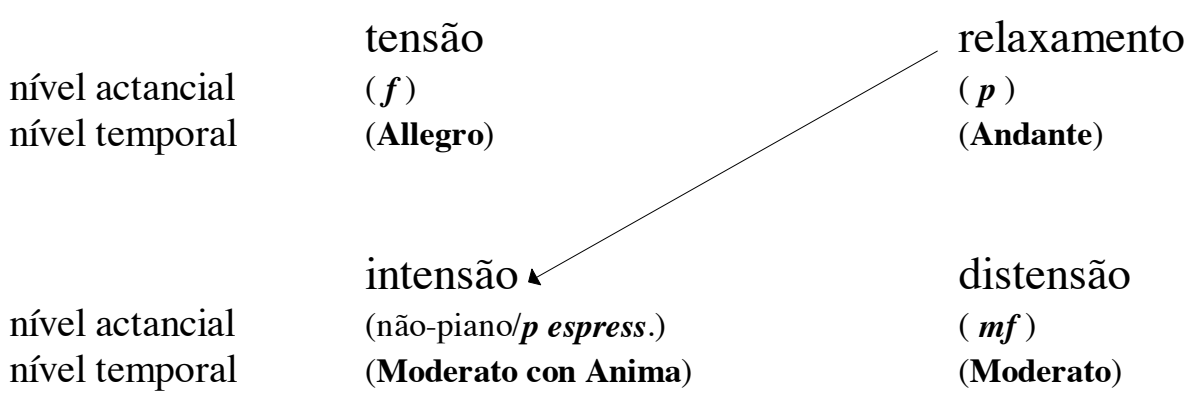

Levando-se porém em conta o contexto, chega-se a um outro resultado, a partir da relevância de dois fatores: 1) a introdução é apresentada basicamente em fortissimo, o que implica num movimento de distensão, e não de intensão, em direção ao piano espressivo; 2) O sostenuto do Andante sostenuto apresenta o tempo inicial não como referencial, mas já como aspectualização de um tempo de referência subseqüente, que acaba caracterizando-se ao longo do I movimento como Moderato. Assim, há também no aspecto temporal uma distensão em relação a um tempo exageradamente lento, e o diagrama passa a ser:

nível actancial nível temporal

$\begin{array}{ll}\begin{array}{l}\text { tensão } \\ (\boldsymbol{f} \boldsymbol{f}) \\ (\text { Andante sostenuto) }\end{array} & \begin{array}{l}\text { relaxamento } \\ (\boldsymbol{p}) \\ (\text { Moderato Assai/Andante) }\end{array} \\ \begin{array}{l}\text { intensão } \\ (\boldsymbol{m} \boldsymbol{f} / \boldsymbol{f}) \\ (\text { Stringendo })\end{array} & \begin{array}{l}\text { distensão } \\ (\boldsymbol{p} \text { espress })\end{array} \\ & \text { (Moderato con Anima) }\end{array}$

Assim, verifica-se prontamente uma primeira identidade no plano do conteúdo dos dois discursos, através de uma coincidência de seus respectivos percursos tensivos: a distensão é coerente com a transição entre o desdobramento polêmico/revolta e o "abandono à tristeza estéril"/resignação do texto verbal. Outro elemento, embora um tanto quanto simplista, que não se pode deixar de considerar é o uso de uma tonalidade menor (Fm). A práxis operística ocidental conduziu a uma certa polarização fórica entre o uso de tonalidades maiores associadas a momentos de conjunção eufórica na narrativa e tonalidades menores associadas a disjunções disfóricas. Embora tal correspondência seja estranha a culturas não-ocidentais em geral e a algumas culturas de origem oriental radicadas posteriormente na Europa em particular, como as culturas zíngara, hebraica e eslava, o efeito de disforia das tonalidades menores é praticamente um ponto pacífico para ouvintes ocidentais, auxiliando aprioristicamente o estabelecimento do estado patêmico sugerido por Tchaikovsky. Mas, obviamente, isso está longe de resumir os recursos da linguagem musical postos em funcionamento pelo autor para a geração dos efeitos de sentido descritos previamente.

Dando curso à nossa análise, iremos agora, ao contrário de nosso procedimento habitual, analisar inicialmente a figura de acompanhamento, buscando inferir a partir de seus elementos rítmicos, harmônicos e melódicos o fluxo modulatório por ela gerado com suas devidas aspectualizações. 


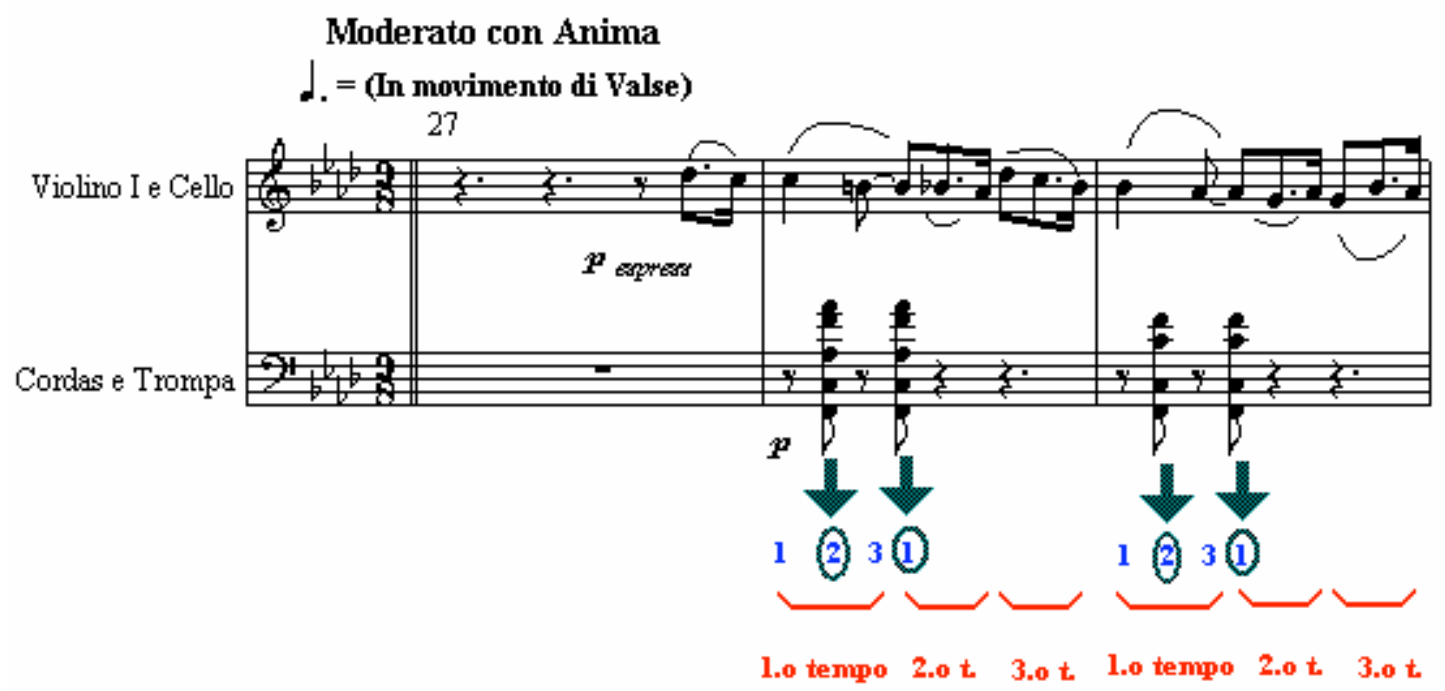

O primeiro dado a ser computado é a incidência pontual e sincopada dos acordes. Logo que estabelecido o tempo rítmico por sua ocorrência regular a cada $2 / 3$ de tempo, ocorre uma interrupção no 3.0 tempo que vem a se estabilizar, em parte quebrando e em parte consolidando uma regularidade. No compasso 34, a primeira metade do motivo entre em looping, evidenciando uma aceleração no tempo cinemático que se acentua e chega a seu limite no compasso 35:

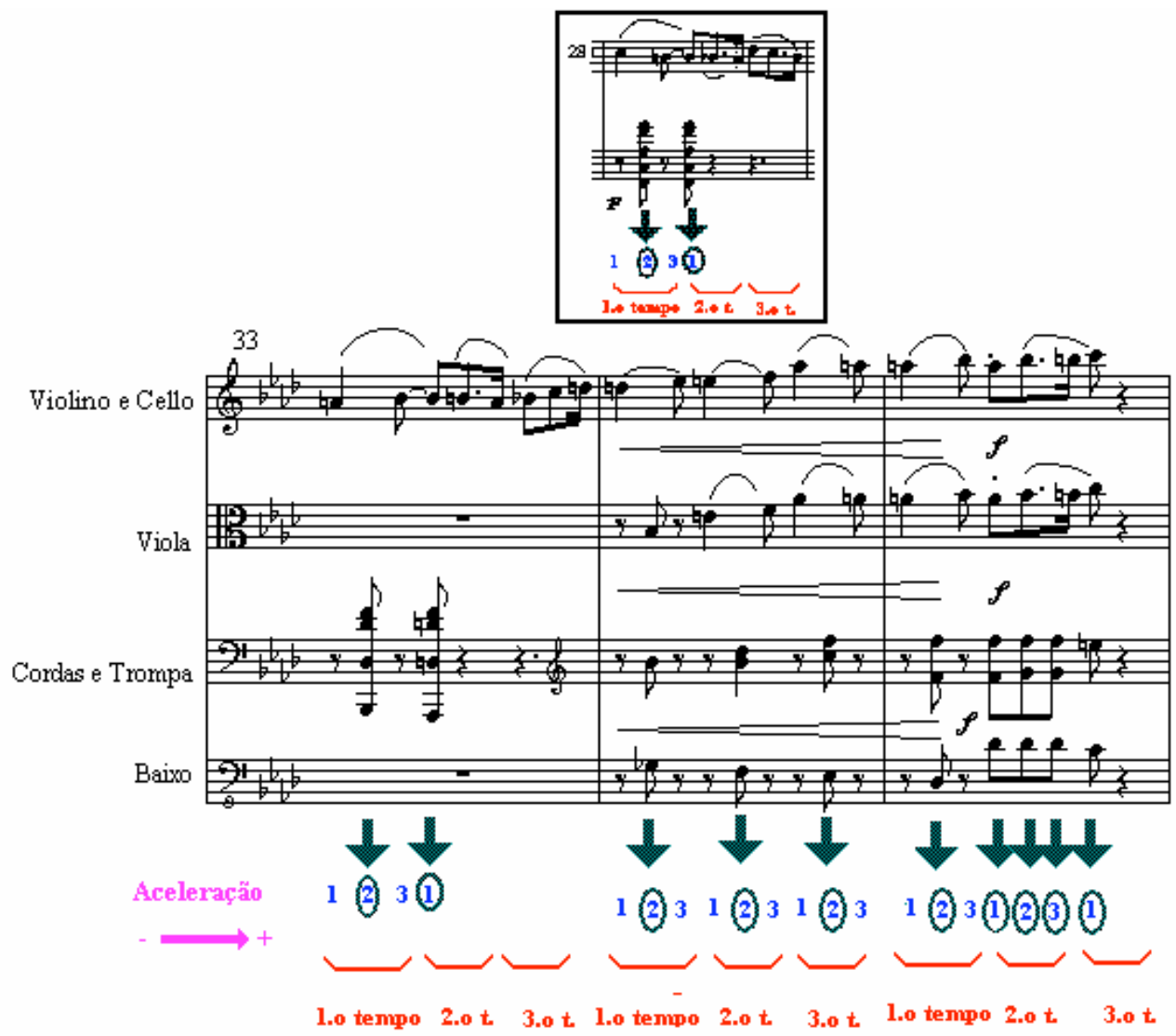

Em se tratando de um percurso relacionado por convocação ao nível profundo, a aceleração deverá remeter a alguma alteração no percurso tensivo; no caso, a um tensionamento. 
Seja agora o mesmo trecho considerado sob o prisma harmônico. Do compasso 28 ao 30, há um ostinato sobre o acorde de Fá menor, que é apresentado a cada compasso numa tessitura um pouco mais grave, acompanhando o movimento descendente da melodia:

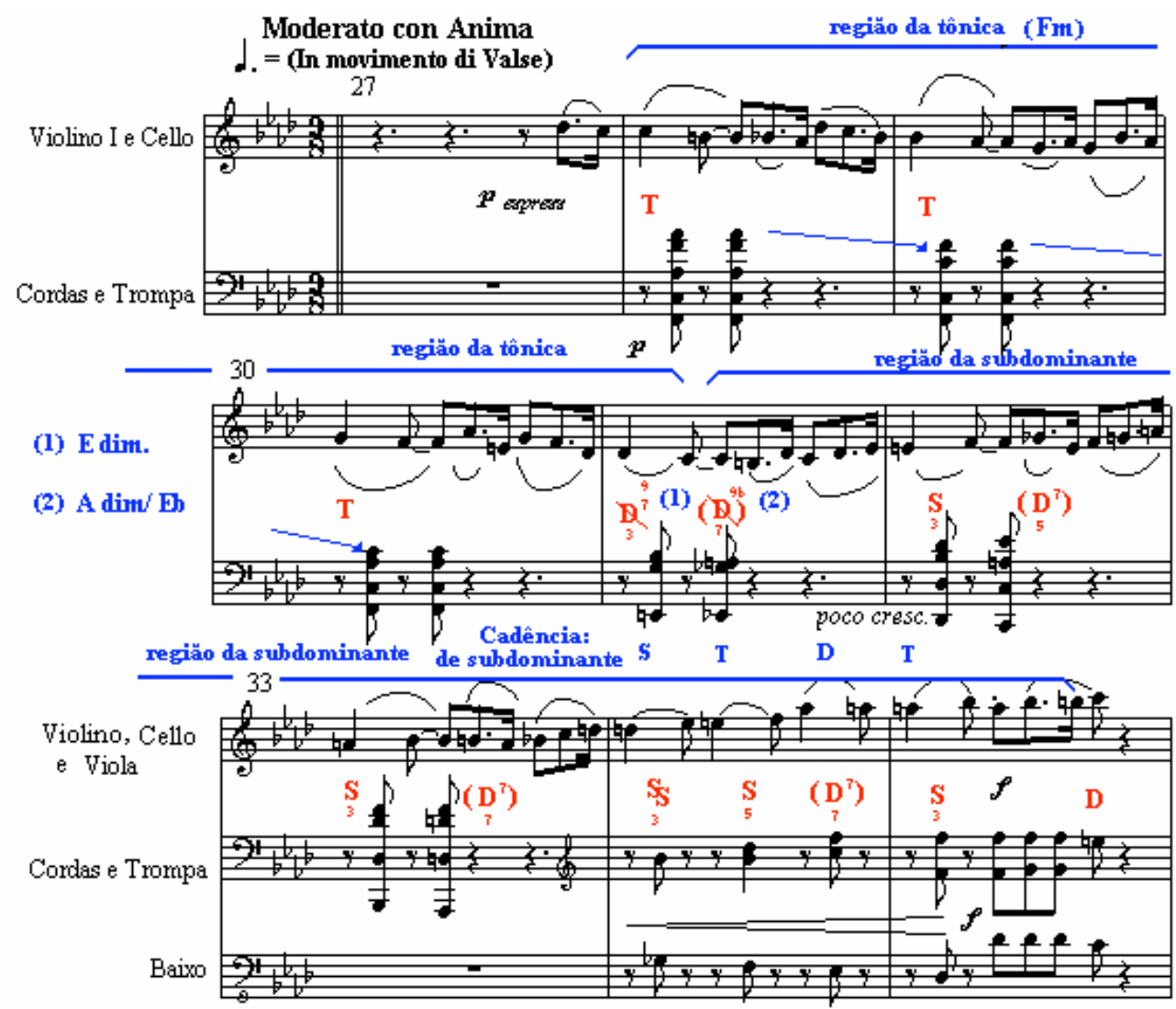

Do compasso 31 ao 35 , a harmonia permanece na região da subdominante, sob a forma de progressões que transformam acordes menores em dominantes individuais. O percurso harmônico descrito caracteriza-se por:

1) uso recorrente de acordes de diminuta

2) polarização da subdominante enquanto centro tonal , confirmada por cadência no compasso 34 e em seguida anulada pelo acorde de dominante no último tempo do compasso 35 .

Consideremos que:

a) Após 3 compassos de invariância, o ritmo harmônico acelera-se vertiginosamente, passando a dois (c.31 a 33) e depois a 3 (c.34) acordes por compasso; quando finalmente se reestabiliza sobre o acorde de subdominante, o foco da direcionalidade é novamente negado pela dominante, que redireciona para a tônica (c.35)

b) os acordes de diminuta, como nos mostra Schoenberg, são acordes errantes, ou seja, que desfocalizam a direcionalidade harmônica;

c) progressões de dominantes não tem foco definido, direcionando-se sempre para o acorde seguinte e estabilizando-se tonalmente apenas através de uma cadência; 
d) após 3 compassos de fixidez e 3 de progressão sem foco definido, a cadência é imediatamente negada pelo acorde de dominante no c.35;

O quadro resultante apresenta um máximo de direcionalidade com um mínimo de foco; em outras palavras, o foco é o ponto imediatamente posterior, não sendo visível claramente um foco comum para toda a progressão. Após uma estabilidade harmônica razoavelmente acentuada, considerado o contexto em que se insere, segue-se uma progressão harmônica tão vertiginosa que sua direcionalidade perde o foco, terminando por não se consumar a transição de centro tonal e por se retornar ao estado inicial. Evidencia-se nesse trecho uma intensão dos mecanismos discursivos, numa aspectualização que conduz o discurso à concentração, estabelecendo-se um percurso rumo à tensão. Temos, entretanto, mais elementos para avaliar as transformações tensivo-fóricas: as aspectualizações das próprias modulações do devir, aparentadas com a apresentação das configurações modais do discurso verbal. Já havendo discutido aspectos harmônicos e dinâmicos, vejamos na figura abaixo em destaque as modulações aspectualizadas rítmica e melodicamente (no que se refere à figura de acompanhamento):

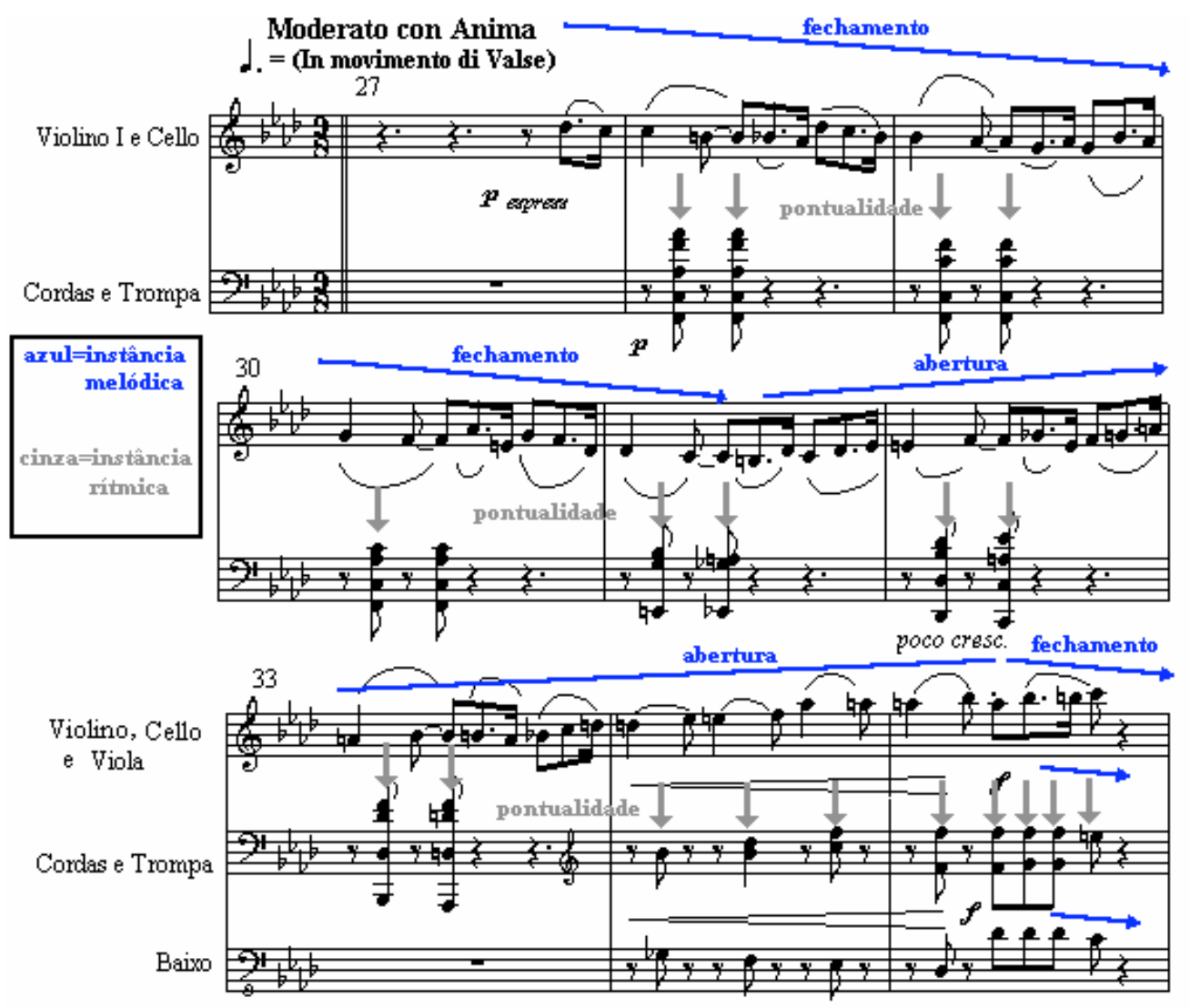

Ritmicamente falando, a incidência dos acordes determina uma pontualidade no discurso. Melodicamente, há fechamento, seguido de grande abertura, curta cursividade e fechamento. Harmônica e dinamicamente, há cursividade (detectável enquanto estabilidade) e abertura crescente (detectável enquanto intensão). Para melhor visualização da composição modulatória resultante da sobreposição das quatro instâncias discursivas peculiares à linguagem musical ${ }^{*}$, façamos um diagrama:

\footnotetext{
* Trata-se simplesmente de abordar a linguagem musical a partir de dois fundamentos: o primeiro, diretamente relacionado à substância sonora e ao mesmo tempo apontando para a música enquanto
} 


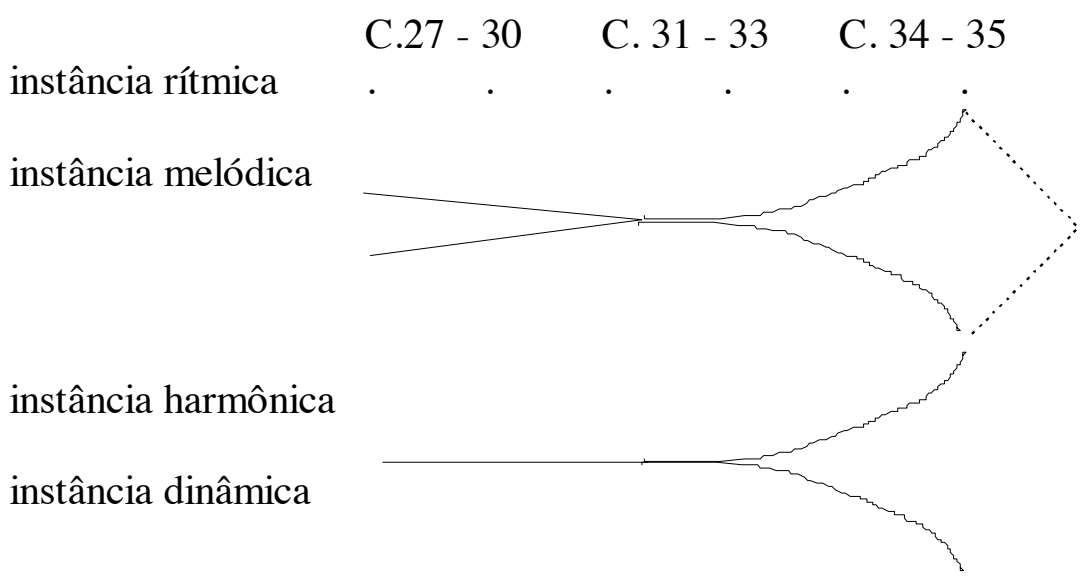

A incidência rítmica pontual, por determinar a apresentação do material e por ser a referência de regularidade, assume um papel organizador hierarquicamente superior às demais instâncias, que a ela ficam assim subordinadas. Raciocinando-se a partir das conversões ao nível narrativo das aspectualizações modulatórias, ou seja, a partir das categorias modais, observa-se na primeira metade do segmento um dever (pontualidade) reconhecido por um saber (terminatividade) e a negação de um poder (interrupção rítmica da cursividade por descontinuidade). Na segunda metade, predomina um querer (abertura) cuja aceleração e irregularidade denotam negação do crer (ausência de cursividade por imprevisibilidade, caracterizando impotência epistêmica) e de realização (outra forma de terminatividade, à qual se segue uma mudança de estado, com a estabilização de uma nova ordem). O fechamento final na instância melódica gera um efeito de terminatividade e finalização, sugerindo um saber enquanto sanção cognitiva.

Antes de tirarmos qualquer conclusão a respeito de uma possível configuração modal do trecho citado, urge lembrar agora que foi tratada apenas a figura de acompanhamento. Faz-se mister analisarmos agora a melodia propriamente dita e, apenas posteriormente, após estabelecido estar a mesma em relação de acordo, neutralidade (no caso, contrariedade) ou polêmica com respeito à configuração modulatória e aspectual do acompanhamento, concluirmos por uma configuração modal resultante da sobreposição das instâncias discursivas. A consideração da melodia, nesse caso em especial, requer um certo detalhamento e aprofundamento sem o qual não teria sido possível fundamentar além do nível intuitivo as conclusões a que chegamos sobre os aspectos de seu comportamento tensivo. Acreditando ser justamente esse percurso que por meio de uma paciente decupação nos permite desacelerar a apreensão cognitiva imediata e recuperar analiticamente o processo sintético de percepção e sensibilização instantâneas uma das principais contribuições do modelo de percurso gerativo de sentido, dar-nos-emos aqui a liberdade de um mergulho mais profundo nas minúcias do texto musical, após o qual retomaremos, a partir de suas conclusões, nosso estudo das modalidades. Por razões de ordem técnica ${ }^{189}$, o trecho a seguir correspondente a essa

sistema semi-simbólico, provém das propriedades básicas do som: altura (intância melódica), intensidade (instância dinâmica), duração (instância rítmica) e timbre (metodologicamente incluído na instância melódica). O segundo diz respeito ao próprio fundamento da música ocidental: a harmonia, de maneira geral, e a tonalidade com sua gramática, em particular (instância harmônica).

${ }^{189} \mathrm{O}$ programa utilizado para a redação deste texto, Word 6.0 para ambiente Windows 3.1x, é totalmente incopatível com o programa mais próprio para a realização de análises musicais, neste caso o Encore 4.01 para o mesmo ambiente. Devido a isso, a inserção de um texto do Encore no Word só é possível através de um artifício do Windows: a fotografia da própria tela do computador, sua conversão para o 
análise apresenta uma formatação peculiar que o destaca desta sessão e daquela onde retornamos à investigação da configuração modal. Vamos, pois, à análise da melodia em suas instâncias melódica e rítmica (as instâncias harmônica e dinâmica, por sua própria natureza, não diferem nesse caso entre melodia e acompanhamento).

Consideremos apenas a instância rítmica da melodia:

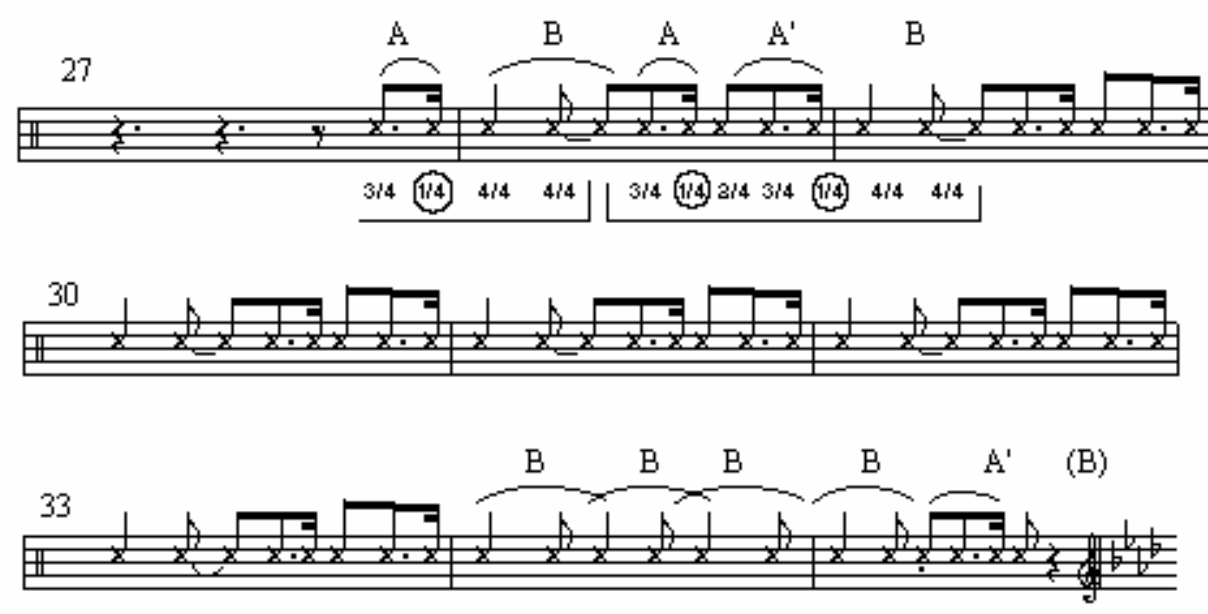

Observemos que:

1) O segmento A - A'- B constitui um ostinato, repetido dos compassos 27 a 33 (pode-se tranqüilamente considerar o elemento A no anacrúsio do compasso 28 como um fragmento de A', estabelecendo-se a ciclicidade do elemento rítmico);

2) No compasso 34, o segmento entra em looping pela reiteração e sobreposição do elemento B, evidenciando uma aceleração;

3)No compasso 35, a aceleração continua, mas o looping é encerrado pela retomada do fragmento A'(B).

A partir disso, conclui-se imediatamente que:

I - O trecho acima é composto pela reiteração de uma única célula rítmica, reiteração essa que sofre uma aceleração a partir do compasso 34 .

Partamos agora para uma análise da célula propriamente dita. Constatamos que:

1) Ela é apresentada inicialmente como composta pelos elementos A e B, intercalando-se entre eles em seguida um elemento A';

2) A sequiência A-B apresenta uma direcionalidade rítmica orientada da menor (3/4) à maior (4/4) duração, pontuada por um elemento enfático de preparação (1/4). Há, em última análise, uma abertura modulatória indicada pelo aumento das durações ao longo da progressão;

3) O elemento A' possui em sua estrutura interna a mesma abertura modulatória descrita acima, com durações em progressão de $2 / 4$ e 3/4, pontuadas enfaticamente por um elemento de $1 / 4$;

4) A' se insere entre A e B com função enfática, evidenciando uma concentricidade entre A - A'- B e A B, sendo A' portanto um desdobramento discursivo do elemento de preparação;

5) A - A’ - B configura, em última análise, uma modulação de abertura.

Concluímos a partir disso que:

formato bitmap e a importação do arquivo .bmp para o Word como Figura. Tal procedimento, se viabiliza a troca de material entre os dois programas, não nos permite entretanto qualquer controle sobre a formatação do material originário do Encore, razão pela qual o texto em questão aparece aqui, involuntariamente, em destaque (n.do a.). 
II) A reiteração da célula rítmica da melodia configura uma abertura modulatória, cuja reiteração gera o sentido de aspectualização da mesma por duração e/ou exagero;

III) Tal abertura sofre uma aceleração no compasso 34, chegando ao limiar de mudança de estado em 35 , sem, entretanto, realizar a transformação;

IV) $\mathrm{O}$ retorno final do segmento $\mathrm{A}^{\prime}$ - B configurando o fim do looping gera um efeito de sentido de terminatividade.

intervalares:

Detenhamo-nos agora na instância melódica. Observemos primeiramente as relações
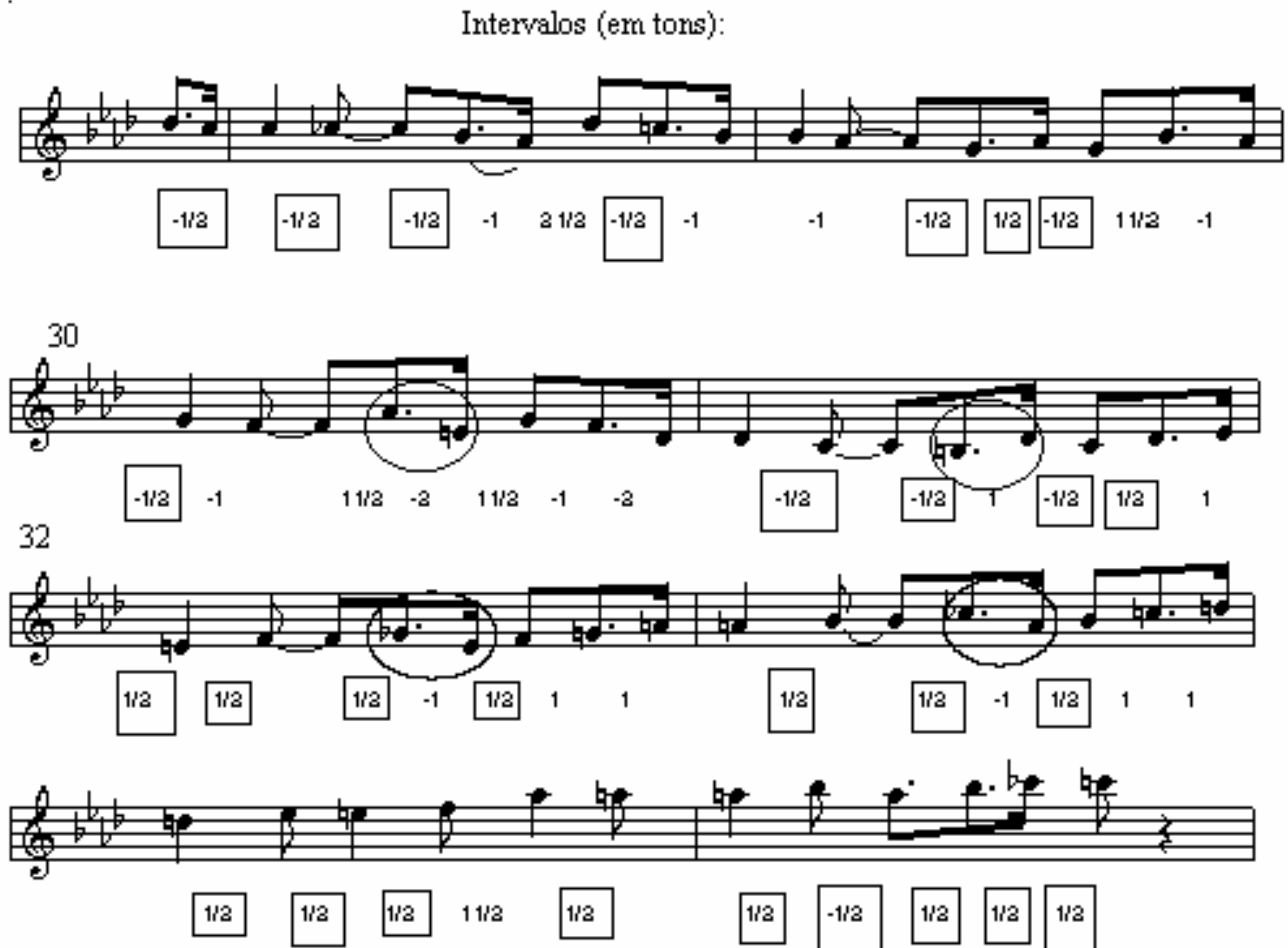

Observemos que:

1) Dos 49 intervalos do segmento melódico, 28 são cromáticos (assinalados com quadrados correspondem a 57\% do total de intervalos) e 4 enarmônicos (assinalados com círculos - correspondem a $8 \%$ ), totalizando $65 \%$, o que caracteriza o trecho como predominantemente cromático;

2) Enquanto a tonalidade e o diatonismo apontam para um centro tonal, focalizando a direcionalidade melódica e tensiva, o cromatismo neutraliza o foco do discurso, o que esvaziaria os efeitos de realização e conclusão, não estivessem eles bem definidos pela regularidade da instância rítmica;

3) Entre o compasso 27 e metade do 31 , dos 22 intervalos, 15 são negativos $(68 \%)$, caracterizando o trecho como descendente, implicando uma modulação terminativa;

4) Entre a metade do compasso 31 e o final do segmento, dos 27 intervalos, 23 são positivos, caracterizando o trecho como ascendente, implicando uma modulação de abertura;

5) Todos os intervalos iniciais do trecho ascendente são enarmônicos, e portanto, afocais;

6) Todas as cabeças de compassos são suspensivas, o que determina que todas as sub-frases tenham terminação feminina, gerando uma direcionalidade tensiva crescente do início para o fim de cada uma delas.

Consideremos agora o segmento em questão quanto à regularidade de seus padrões melódicos. Mantida intacta a harmonia, pensemos o trecho dividido em duas metades: primeira, regularizada a partir do primeiro padrão ascendente; a segunda, segundo o descendente (mantidos os dois últimos compassos, por serem justificadamente distintos do padrão, dada sua aceleração), ele soaria da seguinte maneira: 


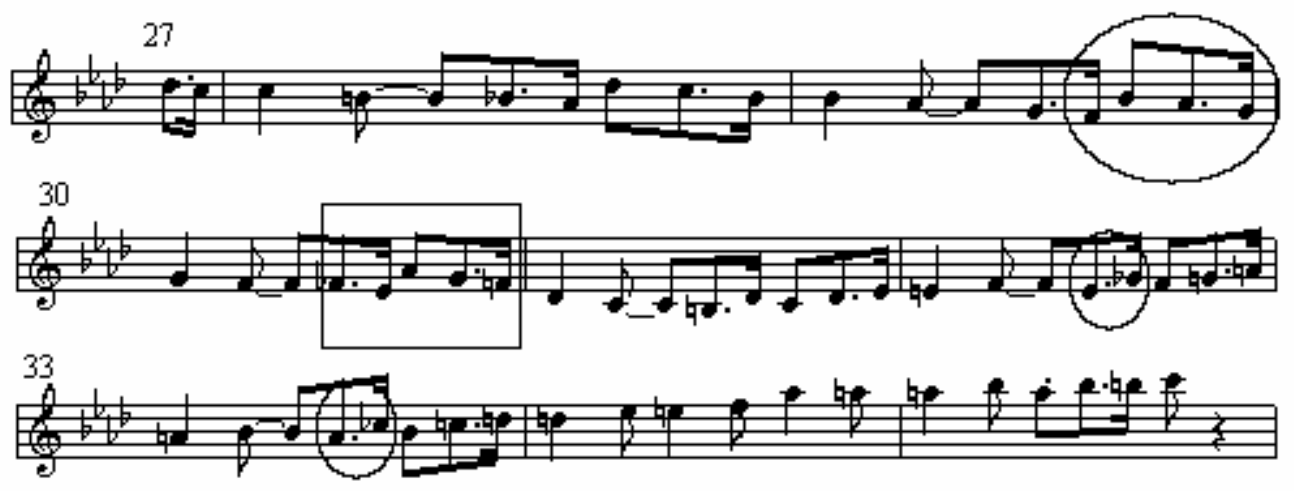

Nos trechos marcados com círculo, houve mudança basicamente apenas na ordem das notas, alterando-se unicamente a direcionalidade do segmento; no trecho marcado com um retângulo, houve alteração na altura das notas, mas não em sua direcionalidade. Concluímos a partir disso que:

V) o contorno melódico do segmento, se bem que basicamente regular, é quebrado em média a cada dois compassos;

VI) Cada célula rítmico-melódica tem direcionalidade tensiva crescente;

VII) O segmento apresenta fechamento modulatório até a metade do compasso 31, e abertura, a partir daí; VIII) A ausência de foco melódico equivale a uma não-cursividade modulatória (inconstância) em relação à instância melódica;

IX) $\mathrm{O}$ crescendo tensivo do item $\mathrm{V}$ corresponde à abertura durativa do item II;

X) O comportamento, no que tange à aceleração, da instância melódica nos compassos 34 e 35 é fundamentalmente o mesmo detectável na instância rítmica (III);

XI) O fato do início do segmento ser composto por três intervalos descendentes de meio tom configura simetria, gerando um efeito de sentido de terminação por fechamento silábico.

Baseando-nos agora nas conclusões expostas na análise acima sobre o comportamento modulatório e aspectual do segmento melódico, façamos um diagrama visando sua melhor visualização:

$$
\begin{array}{lll}
\text { C. } 27-30 & \text { C. } 31-33 & \text { C. } 34-35
\end{array}
$$

instância rítmica

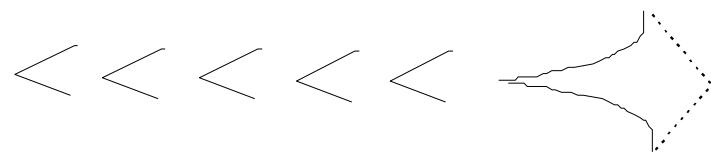

instância melódica

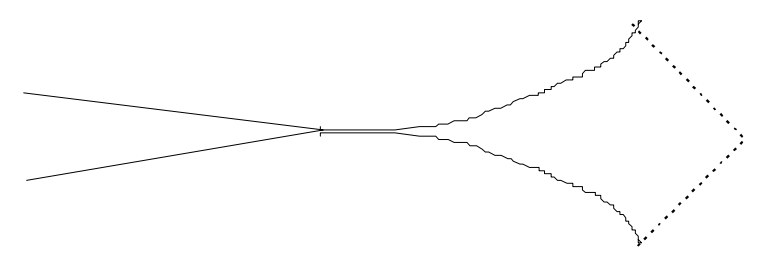

instância harmônica

instância dinâmica

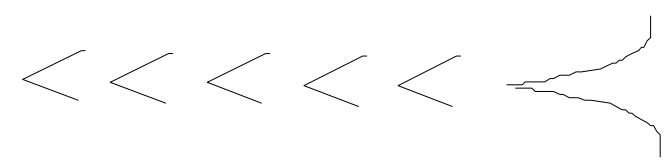

Nas instâncias rítmica, harmônica e dinâmica, a abertura reiterada entre os compassos 27 e 31, sob o ponto de vista modulatório e aspectual, corresponde a um querer durativizado e/ou exagerado, que alcança uma boa definição a partir de seu termo morfológico: um querer obstinado, ostinato. Entre os compassos 31 e 35, acelerase a abertura e perde-se o foco de previsibilidade, ou seja, a cursividade epistemológica, 
gerando um querer exagerado e um não-crer, sancionado cognitivamente no final do segmento, que constitui um clímax tensivo da instância melódica, o único dado novo que se depreende é uma terminatividade entre os compassos 27 e 31, apontando para um saber.

Vamos agora, para finalizar, confrontar o delineamento aspectualmodulatório das figurações melódica e de acompanhamento, a fim de determinar uma síntese modal para o trecho descrito. Por ser essa etapa possivelmente aquela que mais pode vir a contribuir para a semiótica e para a análise musical, pelo relativo ineditismo de sua proposta de buscar o sentido e as paixões do texto musical na fronteira entre modulações e modalidades, cabe desenvolvermos o raciocínio aqui iniciado num item à parte.

\section{iii. Determinação da configuração modal}

O sistema tonal, enquanto sistema de valores lingüístico, elege valores positivos e negativos. Grosso modo, dentro da estética do período romântico da música erudita ocidental, podem-se considerar as "dissonâncias" como valores negativos e, conseqüentemente, disfóricos, e as "consonâncias", enquanto valores positivos e eufóricos. Assim, o grau de dissonância, a distância com relação ao eixo tonal, relaciona-se por convocação com a tensividade fórica, criando um universo contínuo de valores discursivos cobrindo virtualmente todo o percurso entre os pólos eufórico e disfórico. É justamente essa vocação estrutural para a discursivização de uma infinidade de matizes tensivos o fator que singulariza a posição da música entre as linguagens no que tange à construção de efeitos de sentido passional.

Segundo o sistema harmônico formalizado matematicamente por Rameau no século XVIII, a tonalidade menor é menos consoante que a maior, por ser baseada em harmônicos mais distantes da fundamental ${ }^{190}$. Entretanto, não há como negar existir também uma norma de natureza consuetudinária que associa num dado repertório o modo menor à disforia, norma essa oriunda historicamente de uma escolha a princípio aleatória da prática operística, mas que é também igualmente válida enquanto justificação para a atribuição de um caráter fórico. Assim sendo, argumentos tanto de ordem estrutural quanto interdiscursiva fundamentam essa mesma associação, endossando portanto sua utilização enquanto instrumento teórico para o embasamento de uma leitura modal do texto musical. Antes disso, porém, é essencial levantar uma outra discussão.

Assumindo-se a primazia das modulações e aspectualizações e suas respectivas convocações discursivas para efeito de uma abordagem semiótica do discurso musical, uma dificuldade parece se erguer no momento de passarmos das modulações às modalidades: qual o objeto dos verbos modais no discurso musical ? Fazer o quê? Ser o quê? O que quer, crê, pode, deve, sabe o sujeito de um discurso tantas vezes tão afastado de qualquer figurativização?

Tal questão, na verdade, se mostra menos relevante/problemática dentro do modelo greimasiano do que aparenta. Podemos inferir, através dos procedimentos metodológicos utilizados ao longo deste trabalho, informação suficiente para criar um quadro de referência tensivo-fórico que nos forneça, a partir de aspectos tensivos, uma visão do discurso musical em que a lacuna deixada pela ausência de modalidades diretamente explicitadas é suprida pela discursivização de elementos modulatórios e fóricos, resolvendo-nos a questão modal por um outro caminho. Pensando sob o ponto

\footnotetext{
${ }^{190}$ Rameau, 1971:35-42
} 
de vista estritamente teórico, na ausência no discurso de uma clara expressão da discretização das modulações nas quatro modalidades, é o próprio Greimas quem nos sugere pressupô-las a partir das "escolhas aspectuais dominantes" convocadas ao discurso $^{191}$, autorizando portanto aprioristicamente tal abordagem metodológica dentro do próprio modelo. Entretanto, quais seriam, se as há, as consequiências para o discurso como um todo da ausência dessa discretização? Assumindo-se as modalidades enquanto dimensão semântica da relação sujeito-objeto, a ausência dessa discretização sugere uma fluidez naquela relação que acaba também por servir à elaboração de um amplo e abstrato repertório de estados de alma, dificilmente equacionável por arranjos modais.

Freqüentemente, por exemplo, conseguimos captar numa audição aspectos da configuração fórica de um trecho musical. Nesse caso, longe do ser/não-se/fazer/nãofazer, o que verdadeiramente parece importar para a construção de uma perspectiva narrativa do plano do conteúdo é que uma cursividade associada à euforia remete a um poder atualizando o sujeito, afirmando a viabilidade de sua conjunção com os valores do sistema; já uma cursividade associada à disforia, por sua vez, é percebida enquanto atualização do anti-sujeito, repercutindo assim no fortalecimento do agente polemizador adverso à conjunção do sujeito com aqueles valores. A abertura modulatória imprime uma direcionalidade ao discurso percebida enquanto querer, querer esse que aponta sempre para um dado valor do sistema, e a conjunção que aí se virtualiza é por natureza essencialmente eufórica, independentemente de qualquer moralização. Esse querer associado à disforia é percebido como relativo a um sujeito incompetente (não atualizado) ou em contradição com um dever; nesse caso, por aspectualização, geram-se por exemplo estados patêmicos como a aflição ou o desespero. A terminatividade associada à disforia remete analogamente a um saber disfórico, correspondendo sua percepção ao reconhecimento de um estado antagônico ao querer do sujeito, assim como uma terminatividade associada à euforia remete a um saber eufórico, correspondendo a uma sanção cognitiva positiva. A pontualidade incidindo sobre um devir onde predomina a euforia aponta para a necessidade enquanto certeza da conjunção de um sujeito com os valores positivos do sistema, valores esses que por sua vez só são percebidos como tal pela relação que direciona o sujeito para eles, gerando em última análise o efeito de sentido de um querer direcionado paralelamente ao querer do sujeito, ou seja, apontando para o mesmo objeto de desejo. Por outro lado, esse mesmo dever é disfórico quando contrário à direção para que aponta aquele querer. Vemos assim, em última análise, que a questão das modalidades no discurso musical se resolve à medida que a própria linguagem musical, associada à versatilidade da teoria semiótica, apresenta recursos pelos quais sua presença é postulada e avaliada, sugerindo caminhos alternativos de abordagem semiótica do texto que, se bem que metodologicamente distintos daqueles tradicionalmente utilizados no campo verbal e visual, são também não menos rigorosos e fundamentados, não menos compatíveis com o corpus teórico greimasiano e certamente mais pertinentes à natureza do meio de expressão em questão.

Feitas essas importantes considerações, vamos, por fim, à elaboração da configuração modal do trecho analisado. Sobreponhamos os diagramas das figurações melódica e de acompanhamento:

${ }^{191}$ Greimas \& Fontanille, 1993: 170 


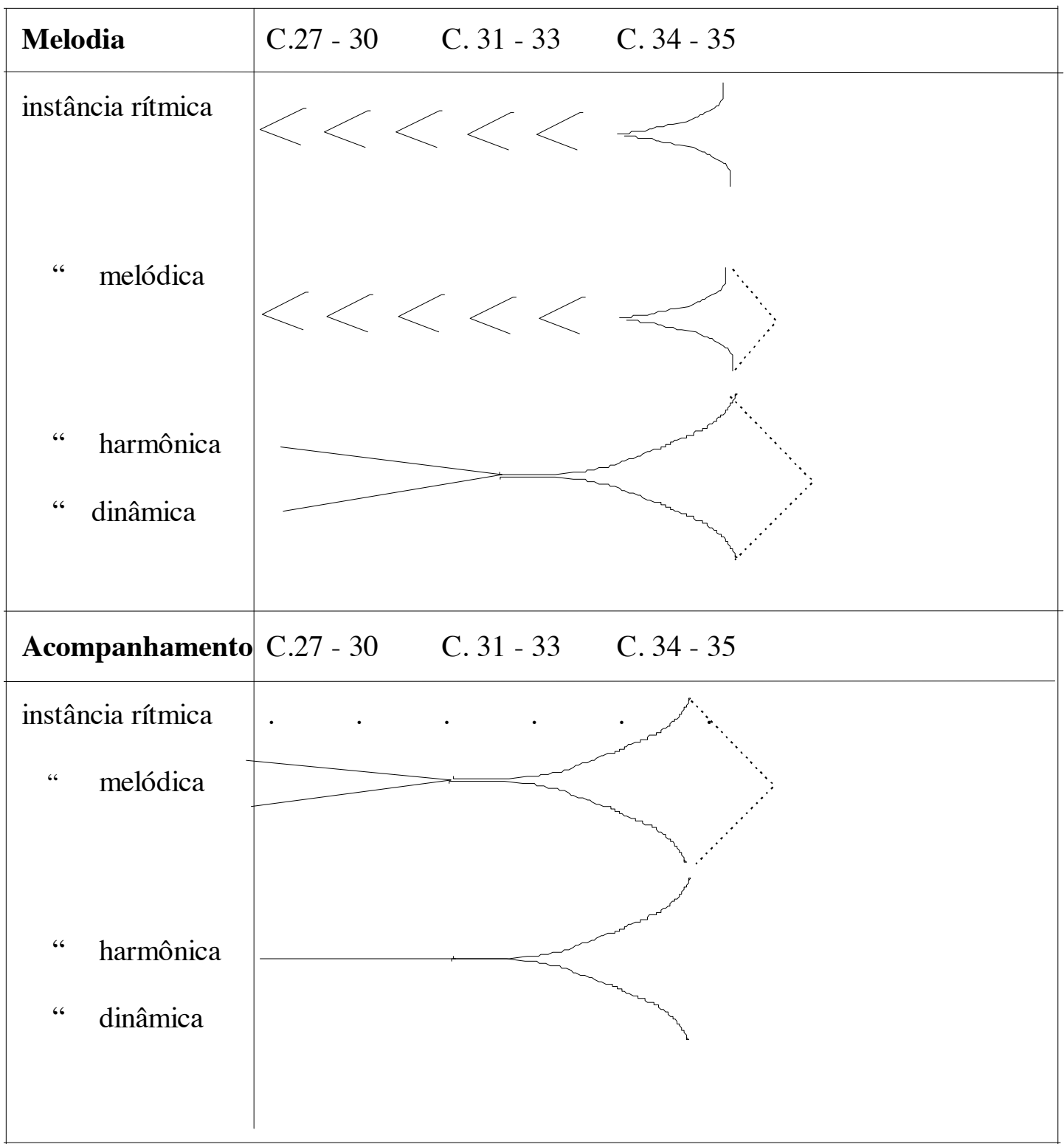

O trecho é predominantemente tenso, devido à intensão resultante das dissonâncias melódicas e à figuração rítmica sincopada, incisiva (e portanto, concentrada e pontualizante) e rarefeita do acompanhamento. A pontualidade desse último virtualiza um dever num contexto disfórico, contrário portanto a um querer. Se assumirmos o ser enquanto ser conjunto com um valor positivo, chegamos a um quererser em conflito com um dever-não-ser.

Observamos pelo diagrama que o princípio rítmico dos ataques no acompanhamento está também presente nas instâncias rítmica e melódica da melodia, porém não sob a forma pontual, mas enquanto impulso de abertura interrompido e reiterado, caracterizando-se a partir dessa incoatividade aspectualizada um querer-ser exagerado, obstinado. A terminatividade das duas instâncias melódicas e da instância 
dinâmica da melodia compõe na primeira metade do trecho um saber disfórico que, como visto, define o reconhecimento de algum antagonismo com o querer nos níveis atualizante e/ou deôntico, estabelecendo um saber-não-ser. Ora, já estando claro o dever-não-ser e conhecendo sua relação lógico-semântica com o não-poder-ser, transitamos através da reiteração em seu aspecto cursivo do saber-não-ser para o sabernão-poder-ser. A cursividade harmônica e dinâmica do mesmo trecho, aliada à disforia, nos conduz a um crer-não-ser, e sua associação à pontualidade rítmica do acompanhamento, de maneira análoga à do procedimento anterior, leva-nos a um crernão-poder-ser, já caracterizando um quadro de aflição. A aceleração da abertura na segunda metade do segmento, aliada à não-cursividade advinda de sua irregularidade compõe um querer exagerado e impotente (não-poder-ser), aspectualizando o estado de aflição em direção ao desespero. A extrema tensão da cadência final não deixa dúvidas quanto à disforia associada à terminatividade melódica, o que, combinado com a cursividade do crescente dinâmico, caracteriza um saber-não-ser contraposto a um poderoso anti-sujeito. Assim, podemos resumir nossa configuração da seguinte maneira:

não ser (disforia)

querer muito ser

saber não poder ser

crer não poder ser

Configura-se assim um quadro de desespero e angústia.

Confrontemos agora, para terminar, os efeitos de sentido passional resultantes do equacionamento modal relativo aos respectivos planos do conteúdo dos dois textos de Tchaikovsky.

\section{iv. $\quad$ Modalidades verbais $x$ modalidades musicais}

Il ne nous reste plus qu'à nous résigner, à nous livrer à une tristesse stérile... le sentiment de la tristesse et du désespoir devient toujours plus fort et poignant ${ }^{192}$.

Um primeiro elemento que se evidencia é a aspectualização sob a forma de uma intensão que se acelera implícita em devient toujours plus fort et poignant, marcadamente presente nos dois textos. A não-cursividade (impotência) e a ausência de foco das modulações de abertura finais estão intimamente relacionadas ao traço de impossibilidade de realização que, como vimos em nossa análise do texto verbal, é essencial ao conceito de esterilidade. A tristeza se faz ver no texto musical através da disforia que se discursiviza enquanto percurso de tensão harmônica sobre uma tonalidade menor, e a ausência de alternativas aludida na carta nos remete ao dever-nãoser e ao não-poder-ser detectados na análise da música. Quanto ao percurso pressuposto pelo desespero, ou seja, a etapa do crer-poder-ser, esta corresponde à hesitante cursividade do final do Andante, que deixamos para ser considerada neste momento. Como já vimos, a cursividade no plano epistêmico conduz à modalidade do crer, remetendo aqui ao momento de esperança, à tentativa logo abandonada e transmutada no motivo melódico descendente aflito e, agora sem mais dúvidas, desesperado do Moderato. Fica assim demonstrada a extraordinária analogia entre os planos do conteúdo dos dois textos no que tange à geração de efeitos de sentido passional, demonstrando por ilustração a consistência e a pertinência de uma leitura modal das

\footnotetext{
${ }^{192}$ Tchaikovsky, 1985: 132
} 
modulações e aspectualizações presentes no texto musical enquanto recurso de investigação do percurso gerativo no que tange ao estudo das paixões tal como as entende a semiótica greimasiana e confirmando mais uma vez a eficácia do modelo de percurso gerativo de sentido desenvolvido por Greimas e seus seguidores.

\section{Conclusão}

Procuremos sintetizar e discutir aqui os resultados metodológicos a que chegamos em nossa aplicação do modelo de percurso gerativo de sentido à análise do discurso musical.

A maioria das análises apresentadas neste trabalho teve como ponto de partida a identificação em cada discurso de dois intervalos: um, o principal intervalo associado aos aspectos de intensão; o outro, o principal associado aos aspectos de extensão. Como compreendemos cada discurso enquanto sistema ou estrutura, ou seja, espaço semântico onde cada elemento existe em função de sua relação para com os demais, não há como não reconhecer tal oposição, por menos marcada e mais dinâmica que seja. Ambos os aspectos são também de fácil identificação. A intensão pode se discursivizar, por exemplo, pelo acento dinâmico, pela dissonância harmônica, pelo salto melódico, pela distorção timbrística; a extensão pela diluição dinâmica, pela expansão harmônica, pelo intervalo decomposto escalarmente, pela escolha de timbres (no ocidente, o uso das trompas para servir à comunicação à distância entre os caçadores associou aos instrumentos dessa família um valor de extensão facilmente detectável no repertório clássico). Fundamental é ressalvar que não existe uma gramática pronta; cada sistema, sob a forma de discurso, elege seus próprios aspectos e valores. Dentro daquilo que chamamos de estilo pode haver um tipo de isonomia que reverta nas isotopias cuja recorrência é a própria responsável pelo agrupamento de diferentes textos numa mesma classe; mas isso é tudo, e não basta como referência única ao pesquisador criterioso.

No decorrer da análise, entretanto, por vezes após não mais que uns poucos compassos, percebe-se que o principal intervalo associado à intensão encontra-se em seguida aliado a aspectos extensivos, e vice-versa. $\mathrm{O}$ que poderia à primeira vista parecer ou uma inconsistência do modelo ou uma incorreção em sua aplicação constitui em última análise uma confirmação de rigor teórico. Senão, vejamos.

Pelo modelo de percurso gerativo, aspectos de intensão ou extensão correspondem à convocação ao discurso da instância tensivo-fórica do nível profundo. São justamente as ondulações dessa instância que conferem a instabilidade necessária à fundação de um devir. A direcionalidade presente nesse fluxo, quando vista não através de uma perspectiva horizontal, o que corresponderia às modulações, mas vertical, seccionando o fluxo de modo a apresentá-lo enquanto aproximação ou afastamento, atração ou repulsão, é o que constitui o campo das valências em toda a sua dinâmica. Quando essas valências são assumidas por um sujeito enquanto objetos (ou, no caso da repulsa, abjetos) de desejo, elas se convertem em valores do sistema. Enquanto valores, estabelecem uma relação juntiva com o sujeito, relação essa cuja mutabilidade constitui a própria narratividade do discurso. Assim, a narratividade se funda a partir do fluxo de valores entre sujeitos e pela resultante transformação das relações juntivas. Isso entendido, a súbita alteração descrita no parágrafo anterior nada mais é do que a mais genuína manifestação da economia do sistema, sistema esse que passamos a compreender à medida que conseguimos identificar e interpretar os valores envolvidos em cada transformação de estado.

Possivelmente cause estranhamento a alguns mais afeitos a certas correntes da musicologia que tenhamos eleito intervalos como unidades actanciais 
mínimas de nossa abordagem, e não motivos ou temas, como nos é apresentado pela teoria musical mais tradicional. É preciso reiterar que consideramos aqui o termo "tema" como uma feliz coincidência de nomenclatura entre música e semiótica. Tal afirmação nos obriga, entretanto, a uma demarcação mais clara que estabeleça relações bem definidas entre os dois corpos teóricos. Um primeiro ponto a esclarecer e que sozinho já previne uma série de equívocos é que conceitos tais como, por exemplo, melodia e harmonia, dizem respeito ao plano do conteúdo do texto musical, e não ao seu plano de expressão. Na qualidade de sistema semi-simbólico, é claro que a música faz uso de figuras de expressão; entretanto, na realidade, harmonia, melodia, ritmo, dinâmica e timbre são já categorias de significação, elementos concretos do discurso musical. Se concebemos o nível discursivo do percurso gerativo como aquele em que os valores do sistema são assumidos por um enunciador, criando-se as instâncias actorial, temporal e espacial, não podemos contudo esperar que um processo exatamente idêntico se dê tanto num texto verbal como musical. Na verdade, basta que adotemos a concepção de nível discursivo enquanto aquele em que "as formas abstratas do nível narrativo são revestidas de termos que lhe dão concretude" ${ }^{193}$ para que identifiquemos naqueles elementos os agentes capazes na música de realizar a conversão de valores em percursos temáticos e figurativos. Assim, o tema de uma sinfonia constitui um conjunto de reiterações conceitualmente mais temáticas e isotópicas do que actoriais. Da mesma forma, o motivo - embora muito mais simples - já apresenta freqüentemente a marca de um percurso. Por outro lado, sob um ponto de vista composicional, e não meramente teórico, a actorialidade do intervalo não causa surpresas aos mais atentos. Não se pode exagerar a importância dada por Beethoven, Schoenberg, Stravinsky e Webern ao papel do intervalo na gênese da criação musical. Nas palavras de Stravinsky:

Muito antes de nascerem as idéias, eu começo a estabelecer relações rítmicas entre intervalos. Só então, depois de ter estabelecido minhas relações harmônicas ou melódicas, é que passo à composição. $\mathrm{O}$ ato de compor é a expansão e a organização posteriores do material com que trabalho ${ }^{194}$.

Nossa proposta metodológica de dar início à análise do discurso musical a partir da instância aspectual do nível discursivo prossegue ao estudarmos as projeções no nível de superfície das modulações tensivo-fóricas. As quatro aspectualizações modulatórias previstas por Greimas, quais sejam, incoatividade (abertura), cursividade, terminatividade (fechamento) e pontualidade repercutem nas várias instâncias discursivas de maneira por vezes claramente detectável, por outras carecendo de especial imersão intelectual ou perceptiva do analista para se deixar notar como mais que uma vaga impressão. Ascendência ou descendência melódica, ataques curtos e incisivos e progressões constantes foram alguns dos mecanismos aspectuais que pudemos reconhecer dentre os vários recursos de que dispõe a linguagem musical para a discursivização das modulações tensivas. Identificar as modulações e pressupor uma instância discretizadora que as converta em modalidades é a chave para uma compreensão da dimensão narrativa do discurso. As modalidades, como sabemos, definem a relação do sujeito com os valores do sistema, delineando o vir-a-ser musical nos percursos de aquisição de competência, cujas extremidades/descontinuidades constituem as transformações de estado. Vemos aí uma relação que contrapõe o percurso modal enquanto definidor da dimensão extensa da narrativa à transformação de estado entendida como dimensão intensa. A clareza com que isso se manifesta no fluxo

\footnotetext{
${ }^{193}$ Fiorin, 1992:29

${ }^{194}$ Stravinsky, 1984:9
} 
musical reforça ainda uma outra perspectiva aspectual da transformação de estado. Ao procurar definir a distinção entre o intenso e o exagerado, Greimas deu-se conta de que

toda vez que um dispositivo interactancial atingia certo grau de estabilidade, toda figura passional que pudesse fazê-lo regredir a um estado anterior menos estável seria considerada excessiva... o excesso assinala, no nível discursivo, uma mudança de isotopia, o que, em geral, não é o caso da intensidade..$^{195}$

Procuramos em função disso sempre que possível chamar a atenção ao longo do trabalho para as modulações que impeliam o discurso à intensão, e vimos como freqüentemente esse processo levava a uma ruptura, a uma quebra de isotopia, processo esse que se narrativiza como a consumação de um percurso modal, coroado pela transformação de estado. Em cada ponto de virada, há um momento de indefinição, por vezes suspensão do discurso (5.a Sinfonia de Beethoven, fermatas e final da exposição; Tchaikovsky, 4.a Sinfonia, final da introdução). É a partir de tal instabilidade que se redefinem as relações de atração e repulsão que regulam modalmente a dinâmica entre sujeito e valor. A intensão, levando à concentração, rompendo relações, atinge o status de polêmica ao atingir um estado que poderíamos nomear, emprestando o termo à física, "calor latente"; antes, portanto, da parada propriamente dita. Nesse estado, o efeito de sentido de intersubjetividade, de alteridade que instaura o "outro" no discurso verbal vem à tona exatamente por estarmos lidando com o modo de existência do sujeito, o que se traduz como sua relação para com os valores modais, e não apenas descritivos. O papel do destinador é exatamente o de atribuir valores modais; o do anti-sujeito, o de negá-los; o do sujeito, o de transformálos em valores descritivos. Assim, é através sobretudo do jogo modal, e não simplesmente do actancial ou actorial, que a alteridade se faz notar como efeito de sentido resultante da complexa rede sintática do discurso sonoro. No caso da sinfonia de Beethoven, tivemos um interessante exemplo de relação intersubjetiva ao identificar a função catalisadora do intervalo de 2.a menor, que assumiu freqüentemente o papel de destinador enquanto redefinidor da configuração modal, da direcionalidade pela qual o sujeito passaria a se relacionar com o complexo jogo de tensão e relaxamento que Schenker acreditava ser a própria essência do discurso musical. No caso da sinfonia de Tchaikovski, foi o anti-sujeito que se fez sentir, instaurado sob a forma de uma estrutura actancial exagerada, disfórica, intensa e centralizadora, cuja atuação ao longo da sinfonia é sintomaticamente a de negação da direcionalidade, do fluxo modal. Ficou patente assim, em suma, a alteridade não mais exclusivamente como um fenômeno de superfície ligado à figura do ator, ou mesmo como cadeia meramente intersubjetiva, em favor de uma visão onde o sujeito e seus pares antagônicos são apenas as extremidades, os nós onde se entrelaça a teia modal.

Outro ponto a se destacar é o que diz respeito à teoria musical propriamente dita. Ao longo da pesquisa que resultou neste trabalho, a teoria musical pareceu se apresentar, num primeiro momento, como adversária da semiótica, tecnicizando a análise com uma nomenclatura prolixa, milimetricamente detalhista e, aparentemente, completamente inútil no que diz respeito à busca de qualquer elemento estrutural de ordem semântica que pudesse nos auxiliar a recuperar o percurso gerativo de sentido. Contudo, por um caminho que parecia cada vez mais obscuro, o sentido musical se fazia notar, insistindo em desafiar a insuficiência de meios analíticos trazendo a cada audição um universo fascinante de efeitos de sentido sem que se pudesse ter a mais vaga noção de como aquela massa sonora pudesse transmitir qualquer sensação além de suas próprias simetrias e assimetrias. Fosse o caso de se aceitar ser

${ }^{195}$ Greimas \& Fontanille, 1993: 170 
tudo aquilo o produto da apreensão intelectual de relações estruturais de proporção, talvez ocorresse a alguém, ao invés de escutar uma boa música, tirar da estante os Principia Mathematica de Newton ou deleitar-se estudando as relações entre o cálculo tensorial e o Universo de Minkovsky. A indisposição ante à musicologia entretanto começou a ruir quando indagações a respeito do que representaria na música uma debreagem temporal enunciva, ou ainda, que mecanismo discursivo equivaleria ao uso do pretérito imperfeito do subjuntivo (trata-se de um episódio real, e não de uma mera construção estilística) mostraram que, naquele momento, o despreparo da musicologia para lidar com o sentido era proporcional àquele de uma teoria até então voltada para o universo verbal ao deparar-se pela primeira vez com uma linguagem que aparentemente não estabelecia a mais remota relação com o mundo natural, condenando-se voluntariamente a uma vocação tautológica. A solução para o impasse veio após ouvir uma leitura dramática de As Cabeças Trocadas, de Thomas Mann. A curiosa indagação sobre tempos verbais fez ver que havia diferenças estruturais importantes entre a organização do nível discursivo verbal e musical, diferenças essas não assumidas num primeiro momento. E, lembra-nos Fiorin, "na análise, caminhamos do mais concreto ao mais abstrato, do mais complexo ao mais simples" (Fiorin, 1992:17), o que remete à necessidade de ter na análise do plano discursivo o ponto de partida para uma investigação do percurso gerativo. Feitas as ponderações já descritas em parágrafo anterior, que conduziram à conclusão que o imenso instrumental teórico musicológico estava na verdade à serviço do mapeamento de seu nível de superfície, coube à semiótica realizar o resto do trabalho, resolvendo questões que a teoria musical há muito desistira de ver desvendadas. Uma delas, bastante enfatizada no item voltado ao estudo da sintaxe narrativa, diz respeito ao mecanismo de variação. A musicologia há muito postula que o texto musical se organiza e estrutura a partir da variação de um motivo rítmico-melódico principal. Contudo, mesmo sendo por vezes capaz de identificar algumas dessas variações no bojo do discurso, a musicologia não soube desvendar nem como nem por que aquelas variações poderiam vir a constituir a estrutura básica de textos de alta complexidade. Através de uma abordagem semiótica, pudemos facilmente compreender as variações enquanto transformações de estado resultantes de um fluxo de valores. Assim, determinados os valores em questão, foi possível responder como aconteciam as variações. Os dois exemplos mais importantes foram encontrados em nossa análise da 5.a Sinfonia, onde pudemos constatar ser o 2.o Tema derivado do 1.o Tema pela inversão de papéis entre os intervalos portadores dos valores de intensão e extensão, num procedimento em que, sem relevar uma perspectiva semântica, o musicólogo não é capaz de reconhecer as relações de derivação que sob a outra ótica tornam-se transparentes. No segundo exemplo, vemos a figura melódica da transição que conduz à codeta repetir-se com aparentemente uma única variação, que a teoria musical se contentaria em chamar de ornamentação, mas que vimos constituir em última análise a substituição de um elemento de intensão pelo próprio intervalo portador dos valores de intensão, num processo rigorosamente estrutural e orgânico em nada assemelhado à casualidade de um procedimento trivial de embelezamento melódico. $\mathrm{Na}$ mesma trilha que atesta a interrelação entre estatutos sintáticos e semânticos no discurso musical encontramos o tipo de relação que denominamos estrutura concêntrica. Por estrutura concêntrica entende-se a relação de analogia entre a organização macro e microestrutural do texto musical. O mais importante a se destacar é que tal relação apresenta-se de uma forma tal que sugere que a sintaxe da macroforma derive da organização semântica (tensiva) da microforma. Por exemplo: vimos que a estrutura tensiva dos compassos introdutórios da sinfonia de Beethoven se organizava da intensão à extensão; observamos em seguida que os dois episódios do 1.o Tema tinham a mesma 
organização entre si, e verificamos, em seguida, que a mesma relação era válida entre o 1.o e o 2.o Tema, passando assim a ordenar toda a exposição. Vemos assim algo como uma pedra caindo sobre um lago, gerando a partir de um único gesto tensivo fundador estruturas formais de ordem crescente de complexidade, apontando assim mais um caminho para o suprimento das lacunas metodológicas da musicologia, à medida que se passa a vislumbrar outro meio pelo qual a variação de um motivo possa dar origem a textos da complexidade de uma sinfonia.

Finalmente, foi também através do postulado de uma instância discretizadora das modulações tensivas, convertendo-as em modalidades, que fundamentamos nossa incursão no território proibido da semântica narrativa, onde se descortinam através das configurações modais os chamados estados de alma do sujeito potencializado. Se um estudo das paixões na música parece à primeira vista irremediavelmente condenado ao subjetivismo ou a sucumbir diante da formidável argumentação de Hanslick, há que se considerar que fomos arremessados a ele impelidos por um outro rolo compressor de igual poder de fogo: a consistência dos resultados obtidos até aquele momento pela abordagem semiótica do discurso musical de maneira geral e pelo estatuto modal visto conforme descrito em parágrafo anterior em particular. Pareceu pouco razoável que o mesmo pressuposto que permitiu uma interpretação bastante consistente da organização estrutural da sintaxe narrativa simplesmente caísse no vazio ao voltar-se para a modalização do ser, dos chamados estados de alma (em contraposição aos estados de coisas). De fato, "doa a quem doer", chegamos a uma flagrante compatibilidade de configurações modais entre o trecho da carta em que Tchaikovski confidencia a Nadezhda Von Meck os sentimentos que quis expressar em sua 4.a Sinfonia e seu correspondente musical. Todavia, algumas colocações precisam ser feitas a esse respeito. A primeira delas é que é mister ficar claro de uma vez por todas que, por partir de uma visão de discurso enquanto sistema, e por esse conceito se maximizar no caso específico da música por todas as razões já expostas anteriormente, não há porque se pensar que se possa chegar a uma "gramática das emoções" na música. As relações dentro de um sistema são dinâmicas; o que aqui é abertura e extensão, ali soa como cursividade e intensão. Não há como estabelecer correspondências estáticas, institucionalizadas. A segunda é que querer, saber, poder, crer e dever são a rigor lexicalizações das modalidades, e não as modalidades em si; uma visão mais abstrata, não presa ao léxico, é fundamental para a compreensão do processo de geração de efeitos de sentido passionais e para a própria apreensão do percurso gerativo como um todo. Por fim, a terceira e última colocação responde ao outro extremo, onde se aloja o ceticismo. É preciso ter uma coisa em mente: que a paixão na música é um fato, e que, como tal, cabe ao pesquisador investigá-lo, e não, negá-lo. Nem toda a argumentação do feroz autor de The beautiful in music foi capaz de apagar do senso comum a definição de música como "arte de expressar sentimentos e paixões por meio de sons" ". Se as configurações modais podem gerar, e geram, efeitos de sentido referentes a estados patêmicos, e se essas configurações são entendidas pelo que elas são, vetores que direcionam e condicionam a relação entre sujeitos e valores, afastando-se assim o fantasma reducionista da prisão às lexicalizações, o semioticista surpreende os musicólogos hoje apontando no próprio Hanslick os fundamentos que justificam sua abordagem da paixão na música:

What part of the feelings, then, can music represent, if not the subject involved in them? Only their dynamic properties. It may reproduce the motion accompanying physical action, according to its momentum: speed, slowness, strength, weakness, increasing and

\footnotetext{
${ }^{196}$ Bellini, 1853
} 
decreasing intensity... This is the element which music has in common with our emotions, and which, with creative power, it contrives to exhibit in an endless variety of forms and contrasts $^{197}$.

Ao admitir a relação entre as propriedades dinâmicas da música, em última análise toda sua dimensão aspectual, e os efeitos de sentido passional que ela desperta, o célebre crítico deu mais um sinal da inteligência aguda e observadora que imortalizou sua obra. O que teria sido ir longe demais seria ter compreendido que aquelas propriedades eram a extremidade de um percurso, o mesmo percurso que conduzia o ouvinte às alturas celestiais da concepção mais abstrata e imaterial, às alturas tão caras a Beethoven que o fizeram se interromper num recital que ofereceu a seu amigo Goethe ao perceber que esse chorava ao ouvir sua música. Indignado, o grande compositor fechou seu piano e retirou-se, sem se dar conta de que o caminho que conduzia sua música de suas mãos hábeis a seu cérebro privilegiado passava necessariamente pelo coração do poeta.

${ }^{197}$ Hanslick, 1974: 37-38. 


\section{Fontes Bibliográficas}

\subsection{Bibliografia}

ABRAHAM, Gerald. The concise oxford history of music. Oxford, University of Oxford Press, 1988.

AMADO, Jorge. "Uma arte criada ao sabor do tempo baiano". In: História da música popular brasileira. São Paulo, Abril, 1982.

ARISTÓTELES. Poética. Barcelona, Bosch, 1985.

[ASAFIEV] ASSAFJEW-GleBOW, B. W. (n.d.). Tschaikowskys "Eugen Onegin": versuch einer aanalyses des stils und der musikalischen dramaturgie. Potsdam: Athenaion.

AUTHIER-REVUZ, J. "Hétérogéneité montrée et hétérogeneité constitutive: Élements pour une approche de l'autre dans le discours". Paris, DRLAV, Revue de linguistique (26):91-151, 1982.

BAKHTIN, Mikhail. Marxismo e filosofia da linguagem. São Paulo, Hucitec, 1986. . Estética da criação verbal. São Paulo, Martins Fontes, 1992. . Esthétique et théorie du roman. Paris, Gallimard, 1970.

BARRICELLI, Jean-Pierre et GIBALDI, Joseph. Interrelations of Literature. New York, MLA, 1982.

BArros, Diana L. P de. Teoria do discurso: fundamentos semióticos. São Paulo, Atual, 1988.

.Teoria semiótica do texto. São Paulo, Ática, 1990.

BArros, Diana L. P et alii. Dialogismo, polifonia, intertextualidade: em torno de Mikhail Bakhtin. São Paulo, Edusp, 1994

BAS, U. Trattato di forma musicale. Milano, Ricordi, 1955.

BeETHOVEn, L. V. In: An encyclopedia of quotations about music (org: Nat Shapiro). London, David \& Charles, 1978.

BELLINI, Fermo. Manuale di Musica. Milano, Ricordi, 1853.

BENVENISTE, Émile. Problèmes de linguistique générale, 1. Paris, Gallimard, 1966. . Problèmes de linguistique générale, 2. Paris, Gallimard, 1974.

Berger, Arthur Asa. Media analysis techniques. Newbury Park, CA: Sage, 1982.

BURGIN, Victor (Ed.). Thinking photography. London, Macmillan, 1982. 
COKER, Wilson. Music \& meaning. New York, The Free Press, 1972.

COPLAND, Aron. "A modernist defends modern music". In: The New York Times Magazine, New York, Dec. 25th,1949.p. 11.

DuCROT, Oswald. Le dire et le dit. Paris, Minuit, 1984.

DUCROT, Oswald et alii. Les mots du discours. Paris, Minuit, 1980

FIELD, Syd. Manual do Roteiro. Rio de Janeiro, Objetiva, 1982.

FIORIN, José Luiz. Elementos de análise do discurso. São Paulo, Contexto,1992.

FISKE, John. Television culture. London, Routledge, 1987.

FLOCH, J. L. Quelques positions pour une semiotique visuelle. Paris: Le Bulletin, Groupe de Recherches Sémio-Linguistique, I (4-5): 1-16, maio de 1978. "Kandinsky: sémiotique de un discours plastique non figuratif ". In: Communications. Paris, Seuil, 1981.

- Petites mythologies de l'oeil e de l'esprit - pour une sémiotique plastique. Paris/Amsterdam, Hàdes/Benjamin, 1985.

Les formes de l'empreinte. Périgueux: Pierre Fanlac, 1986

"Semiótica plástica e linguagem publicitária". In: Significação. Araraquara, 6:29-50, 1987.

. Sémiotique, marketing et communication. Paris, Presses Universitaires de France, 1990.

.Identités visuelles. Paris, Presses Universitaires de France, 1995.

FuX, Joseph. Gradus ad parnassum. New York, Norton, 1971 (1.a Ed. Viena, 1725).

GILMAN, Ernest B. "Interart studies and the 'imperialism' of language". Art and Literature I. In: Poetics Today 10.1: 5-30. New York, Ed. Wendy Steiner, 1989.

Goodman, Nelson. Languages of Art: An Approach to a Theory of Symbols. 2nd ed. Indianapolis: Hackett, 1976.

GREIMAS, Algirdas Julien. Sémantique structurale - recherche de méthode. Paris, Larousse, 1966.

Du sens I:éssais sémiotiques.Paris, Seuil, 1970.

. Essais de sémiotique poétique. Paris, Larousse, 1972.

. Du sens II:éssais sémiotiques. Paris, Seuil, 1983

Greimas, A. J. \& Courtes, J. Sémiotique. Dictionnaire raisonné de la théorie du langage. Paris, Hachette, 1979.

Sémiotique. Dictionnaire raisonné de la théorie du langage. Paris, Hachette, 1986 
Greimas, A. J. \& FonTANille, J. Sémiotique des passions - des états des choses aux états d'âme. Paris, Seuil, 1991 . Semiótica das paixões. São Paulo, Editora Ática, 1993.

GROVE, George. Beethoven and his nine simphonies. New York, Dover, 1962

HANSLICK, Eduard. The beautiful in music. New York, Da Capo Press, 1974.

HJELMSLEV, Louis. Prolegômenos a uma teoria da linguagem.São Paulo, Perspectiva, 1975.

KIVY, Peter. Sound and Semblance: Reflections on Musical Representation. Ithaca, Cornell UP, 1984.

KURTH, Ernst. Musikpsychologie. Hildesheim: Georg Olms, 1947 [1992].

KRISTEVA, Julia. "Science et Critique et/ou Critique de la Science". Recherches pour une sémanalyse. Paris, Seuil, 1969.

.Le mot, le Dialogue et le Roman”. Recherches pour une sémanalyse. Paris, Seuil, 1969.

.Pour une Sémiologie du Paragrame". Recherches pour une sémanalyse. Paris, Seuil, 1969.

. Le langage, cet inconnu. 2.ed. Paris, Seuil, 1981.

LESSING, Gotthold Ephraim. Laocoön: an essay on the limits of painting and poetry. Baltimore: Johns Hopkins UP, 1984. .

MARCONDES, M.A. (ed.).Enciclopédia da música brasileira: erudita, folclórica e popular. São Paulo, Art Ed., 1977.

MAtos, Gregório de. Poemas escolhidos. São Paulo, Cultrix, 1975.

METZ, Christian. Film language: a semiotics of the cinema (trans. Michael Taylor). New York, Oxford University Press, 1974.

MEYER, Leonard B. Music: the arts and ideas - patterns and predictions in twentiethcentury culture. Chicago, The University of Chicago Press, 1967.

MONACO, James. How to read a film. New York, Oxford University Press, 1981.

NARMOUR, Éugène. Beyond schenkerism: the need for alternatives in music analysis. Chicago: University of Chicago Press, 1977.

NEUBAUER, John. The emancipation of music from language, New Haven, Yale University Press, 1986.

PEIRCE, Charles Sanders. Semiótica. São Paulo, Perspectiva, 1977. 
RAMEAU, Jean Philippe. Treatise on harmony. New York, Dover, 1971.

RoBert, Paul. Le Nouveau Petit Robert. Paris, Dictionnaires Le Robert, 1994.

RoBIN, Régine. História e lingüística. São Paulo, Hucitec, 1977.

RosEn, Charles. El estilo clássico. Madrid, Alianza Editorial, 1972

SALZER, Felix. Structural hearing: tonal coherence in music, Vol. I \& II. New York, Dover Publications, 1962.

SAUSSURE, Ferdinand. Curso de lingüística geral. São Paulo, Cultrix, 1971.

SEBEOK, Thomas A. Semiotics in the United States. Bloomington: Indiana University Press, 1991.

SCHOENBERG, Arnold. Structural functions of harmony. New York, W.W. Norton \& Company Inc. 1969.

Theory of harmony. Berkeley, University of California Press, 1978.

SCHURÉ, Edouard. Hermes. São Paulo, Martin Claret Editores, 1986.

Silva, José Paulo da. Manual de fuga. Rio de Janeiro, Editora da Escola Nacional de Música, 1949.

SONESSON, Göran. Pictorial concepts. Inquiries into the semiotic heritage and its relevance for the analysis of the visual world. Lund: Aris/Lund University Press, 1989.

. "Comment le sens vient aux images. Un autre discours de la méthode". In: De l'histoire dell'arte à la sémiotique visuelle. Carani, Marie (ed.), 29-84. Québec: Les éditions du Septentrion/CÉLAT, 1992

- "Notes sur la macchia de Kandinsky - le problème du langage plastique", in Actes Sémiotiques: le Bulletin , X, 44, décembre; pp. 23-28, 1987

"Les rondeurs secrètes de la ligne droite. A propos de Sans titre de Rothko", dans Nouveaux Actes Sémiotiques, 34-36, 1994, 41-76, 1994.

. "On pictorality. The impact of the perceptual model in pictorial semiotics". Dans The semiotic web: Advances in visual semiotics, Sebeok, Thomas, \& Umiker-Sebeok, Jean (éds.), 67-108. Bloomington, Indiana: Indiana University Press, 1994.

. "Mute narratives. New issues in the study of pictorial texts". A paraitre dans

les

Actes des interart studies: New Perspectives, Lund University, May 15-19, 1995.

STRAVINSKI, Igor \& CRAFT, Robert. Conversas com Igor Stravinski. São Paulo, Perspectiva, 1984. 
STRAVINSKY, Igor. Chronicle of my life. London, Victor Gollancz, 1936

SUBOTNIK, Rose. The cultural message of musical semiology: some thoughts on music, language, and criticism since the enlightenment. In: Critical Inquiry 4 : 741-68,1978.

. Developing Variations: style and ideology in western music.Minneapolis, University of Minnesota Press, 1991.

TARASTI, Eero. “De l'interpretation musical”. In: Actes Sémiotiques (Documents) n.o 42. Paris, EHESS, CNRS, 1983.

"Sur les structures fondamentales du discours musical". In: Actes Sémiotiques (Bulletin) n.o 28. Paris, EHESS, CNRS, 1983.

-org-Semiotica - Semiotics of music. Amsterdam/Berlim/New York, Mouton de Gruyter, 1987.

. Sémiotique musicale. Limoges, PULIM, 1996.

TATIT, Luiz Augusto de Moraes. Por uma semiótica da canção popular. São Paulo, FFLCH-USP, 1982.

- Elementos semióticos para uma tipologia da canção popular brasileira. São Paulo, FFLCH-USP, 1986.

. Semiótica da canção - melodia e letra. São Paulo, Escuta, 1994.

. "Tempo e tensividade na análise da canção". In: Cadernos de Estudo de Análise Musical 3, p.27-84. São Paulo, 1992.

. O cancionista. Sãp Paulo, EDUSP, 1996.

TCHAIKovsky, P. I.. Piotr Tchaïkovsky: écrits critiques, lettres, souvenirs de contemporains. Moscou, Radouga, 1985.

Thürlemann, Félix. Paul Klee. Analyse sémiotique de trois peintures. Lausanne: L'Age d'Hommes, 1982

TOCQueVILle, Alexis de. De la démocracien en amérique. Paris, Seuil, 1963.

TODOROV, T. Mikhail Bakhtin, le principe dialogique, suivi de Écrits du cercle de Bakhtine. Paris, Seuil, 1981.

WAGNER, Richard. Oper und drama, gesammelte schriften und dictungen. Leipzig, Breitkopf \& Härtel, 1871.

. On Conducting. New York, Dover, 1989.

WEBERn, Anton. O Caminho para a música nova. São Paulo, Editora Novas Metas, 1984.

WeStrup, Sir Jack et HARrison, F. Ll. Collins encyclopedia of music. London, Collins, 1985.

WiSNIK, José Miguel. O som e o sentido. São Paulo, Cia. das Letras, 1989. 
Zilberberg, Claude. Raison et poétique du sens. Paris, Presses Universitaires de France, 1988.

"Modalité et pensée modale". In: Nouveaux Actes Sémiotiques. Limoges, Trames, vol. 3, 1989.

"Relativité du rythme". In: Protée - Théories et pratiques sémiotiques. Département des Arts et Lettres de l'Université du Québec à Chicontimi. Vol. 18, n.1, p.37-46,1990.

Pour une poétique de l'attention. Berne, Frankfurt, New York, Paris, Berrendonner, A. et Parret, H. L'Interaction Communicative,1990.

ZiLberberg, C. e FONTANILLE, J. "Valence/valeur". In: Nouveaux actes sémiotiques. Limoges, Pulim, 46-47, 1996.

\subsection{Musicografia ${ }^{104}$}

BACH, Johann Sebastian. "Fuga I". In: Das wohltemperierte klavier. MünchenDuisburg, G.Henle-Verlag, 1970.

BeEthoven, Ludwig von. Simphony n.o 5. New York, Belwin Mills, 1970. . Sonate Op.13 n.o 8 (Pathétique). München-Duisburg, G.Henle-Verlag, 1952.

CAYMMI, Dorival. "É doce morrer no mar". In: Mascarenhas, Mário. O melhor da Música popular brasileira, Vol.VI. São Paulo, Vitale, 1988:190.

GRIEG, Edvard. Aus Holberges Zeit. London, Eulenburg E. E. 6053.

TCHAIKOVSKI, P.I. Simphony n.o 4. London, Eulenburg E.E. 3626. . Serenade. London, Eulenburg E.E. 4646.

\subsection{Multimídia}

GANNON, P. et alia. The pianist ${ }^{105}$, V. 1.04. Buffalo, PG Music Inc, 1993.

\subsection{Sites de pesquisa semiótica consultados via internet ${ }^{106}$}

Charles S. Peirce Studies (04/07/96). URL http://www.nothing.com/peirce/

Cultural Semiotics (25/12/96).URL http://www.bm.lu.se/ arthist/semiotics/ kult_sem_eng.html

\footnotetext{
${ }^{104} \mathrm{Em}$ ordem alfabética segundo autor musical.. Embora todas as obras citadas deste item em diante tenham sido alvo da pesquisa e do interesse deste trabalho, algumas delas não entraram em sua redação final. Optou-se entretanto por manter aqui o seu registro dada a importância indireta de sua consideração para a estruturação deste trabalho (n. do a.)

${ }^{105}$ Repertório para piano executado pela pianista Valerye Tryon.

${ }^{106}$ Citado segundo a norma convencional da internet. Fonte: BLEUEL, J. (1995, November 8). “ Zitieren von Internetquellen" ["Citing sources on the internet"]. URL http://www.unimainz.de/ bleuj000/ zitl.html.
} 
ISI: International $\quad$ Semiotics Institute $\quad(27 / 12 / 96) . \quad$ URL

http://www.helsinki.fi./ mrossi/

Lycos (13/05/96). URL http://www.lycos.com

Nordic Association for Semiotic Studies (04/07/96).

URL http://www.bm.lu.se/ arthist/assoc/nass.html

Organisational Semiotics Forum (24/12/96).

URL http://www.soc.staffs.ac.uk/ cmtkl/ forum.html

Pictorial Semiotics (04/07/96). URL http://www.bm.lu.se/ arthist/sonesson/ pict_sem_4.html\#References

Sites of Significance for Semiotics (27/12/96). URL:

http://www.epas.utoronto.ca:8080/ french/as-sa/EngSem1.html\#SOYO

Semiotics

(04/07/96).

URL

http://www.cudenver.edu/ mryder/itc_data/semiotics.html

Semiotics 95'Conference (25/12/96).

URL http://www.cudenver.edu/ mryder/itc_data/bridge.html

Semiotics of the Media (04/07/96).

URL http://www.uni-kassel.de/fb3/psych/sim/hyper/congress/email.html 